\title{
混和材としてのフライ アッシュに関する研究
}

正員吉越盛 欣*

\section{INVESTIGATIONS ON FLY ASHES AS POZZOLANIC ADMIXTURE}

(Trans. of JSCE, No. 31, Nov. 1955)

By Moritsugu Yoshikoshi, C. E. Member

Synopsis; This article is a report by the auther on a series of studies on the practical use of coal ashes of steam power plants. The article concludes by demonstrating that the various types of ashes are each useful as pozzolanic admixture. Particularly on fly ash, the article spells out in detail its effect on the properties of concrete and suggests new testing methods for the utilization of fly ash.

要 旨: 著者は，火力発電所捨灰の資源化を目ざした一連の実用化研究を報告し，各種のアッシュがポゾラン 混和材として，それぞれ有用であるととを明らかにする。特にフライ アッシュについては，これがコンクリー トの性質に和よぼす影響を細かく追求して諭じ，さらにフライ アッシュ実用上の試験方法について新しい試み を示す。

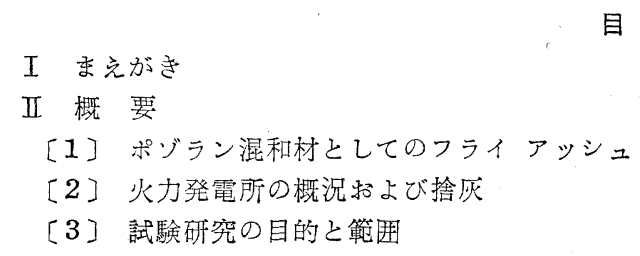

III コットレル系フライ アッシュの化学的ならび 飞物理的性質
[1]フライアッシュ
[2]試験方法
1 比重試験方法
2 粉末度試験方法
3 吸着性試験方法
4 所要水量比試験方法
5 ポゾラン活性試験方法
[3]詿験の結果
1 化学成分
2 色
3 比重
4 単位容積重量
5 䊀子形状
6 粉末度
7 吸着性
8 所要水量比（所要のフローをうる汇必要な 水量)
9 ポゾラン活性
10 ポルトランドセメントの凝結時間飞招よ ぼす影響
11 ポルトランドセメントの安定性に抒よぼ す影響
12 ポルトランドセメントの水和熱汇抢よぼ す影響
IV コットレル系フライアッシュがコンクリート

次

の性質飞和よぼす影響

[1]コンクリート招よび試験方法

1 コンクリート材料

2 コンクリート

3 強度試験方法

4 透水訊験方法招よび耐透水指数

5 凍結融解試験方法

6 断熱温度上昇款験方法

7 乾燥収緢試験方法

〔2]フライ アッシュがまだ固まらないコンク リートの性質飞祘よぼす影響

1 コンクリートのコンシステンジーに执よぼ す影響

2 フライ アッシュオキカエ率招よびコンク リートの配合と単位水量との関係

3 砂の粒度がフライアッシュを用いたコン クリートの単位水量飞招よぼす影響

4 フライ アッシュの所要水量比とフライア ッシュを用いたコンクリートの単位水量との 関係

$5 \mathrm{AE}$ Eコンクリートの単位 $\mathrm{AE}$ E剂量に稆よぼ す影響

6 コンクリートのブリージングに和よぼす影 響

[3]フライアッシュがコンクリートの強度に 招よぼす影響

1 フライアッシュの品質がコンクリートの 压縮強度飞杼よ代す影響

2 フライアッシュオキカエ率和よびコンク リートの配合が压縮強度に叔上代す影響

3 フライアッシュが普通和よび中膺熱ポル トランドセメントを用いたコンクリートの

* 電源開発 $\mathrm{K} \mathrm{K}$ 設計課長代理（関西電力出向） 
圧縮強度に招よぼす影響

4 養生方法がフライアッシュを用いたコン クリートの庄縮強度に括よぼす影響

5 フライアッシュがコンクリートの引張強 度に和よぼす影響

[4]フライアッシュがコンクリートの透水性 に衫よぼす影響

[5]フライアッシュがコンクリートの耐久性 に特よぼす影響

1 凍結融解飞対する抵抗性

2 硫酸ソーダ溶液飞対する抵抗性

[6]フライ アッシュがコンクリートの水和熱 による温度上昇に和よぼす影響

[7]フライアッシュがコンクリートの乾燥収 䋨に福よぼす影響

V ポンドアッシュならびにサイクロン系フライ アッシュの利用比関する試験

[1]概 説
〔2]ポンド アッシュの利用に関する訊験

1 ポンドアッシュ

2 ポンド アッシュの化学成分ならび泩理 的性質

3 ポンドアッシュを用いる混合ポルトラン ドセメントの製造について

[3]サイクロン系フライアッシュの利用に関 する試験

1 サイクロン系フライアッシュの化学成分 ならびそ物理的性質

2 各種乏ルによるサイクロン系フライアッ シュの粉砕試験

3 粉砕したサイクロン系フライアッシュが コンクリートのコンシステンシー括よび压縮 強度に抒よぼす影響

$\mathrm{VI}$ 結 铻

付録 フライアッシュ仕様書案

\section{I. あえがき}

戦後国土再建の水力工事が始まるとともに，海外技術の進歩がつぎつぎそ紹介された。このうちで，ダムのコ ンクリートに関して，最むわれわれが目をみはつたものは，AEコンクリートと，ポゾラン混和材特にフライア ッシュの使用という二項目であつた。AEコンクリートは，平岡ダム(昭和25年)を始めとして，ただちとその技 術が採り入れられたが，フライアッシュはとう簡単には進まなかつた。フライアッシュを始めて水力関係者に 紹介乙たのは，当時日本発送電KKより Hungry Horse Dam の建設工事を視察し，Bureau of Reclamation で H.S. Meissner 氏よりフライ アッシュの説明をうけた野瀬正儀氏で，昭和 25 年初めのことであつた。

昭和 26 年関西電力KK の発足直後より, 同氏によつて管下に巨大な火力発電所をもつ同社が，コンクリート 材料としてアッシュの試験研究を率先遂行すべきであるととが主張された。一方当時, 丸山ダムの早急な完成が 望まれ，多岐にわたる技術的検討の結果，ダムコンクリートの硬化熱の処理が問題となり，わが国最初のプレ クーリングが実施されたが，同時に発熱源の減少をはかるダム コンクリートのセメント使用量の低減,ないしは

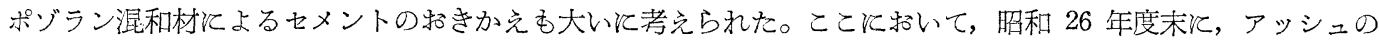
試験研究を行うことの基本方釬がたてられ，昭和 27 年度より「火力発電所のフライアッシュ利用に関する試験 研究」に着手し，量执よび質の両面より，その経济性ならびそ技術的問題の調查研究を行い，試験設借の設置を 含めて, 昭和 29 年度末委でと約 10000000 円の試験研究費を投じた。この間, 昭和 $28 \cdot 29$ 年度に共同研究とし て建設技術研究補助金（主任研究員：大西英一氏）をうけた。

この試験研究により, 火力発電所の各種アッシュのポゾラン混和材としての有用性を確認し, 昭和 28 年度に は，アッシュを用いた混合ポルトランド セメントを製造して，水力建設工事に使用し，その工費の節減寄与 し, 昭和 29 年度初めには, 尼ケ崎第二火力発電所のフライ アッシュ取り出しのためのかりの設借を設けてとの 生産を始め，これを角川発電所工事をはじめ佐久間ダムならびに秋葉公ムの仮設備コンクリートに供した。また 昭和 29 年度末より尼ケ崎第二火力発電所のフライ アッシュ取り出しの本格設備の設置工事が始められ, 䀡和 30

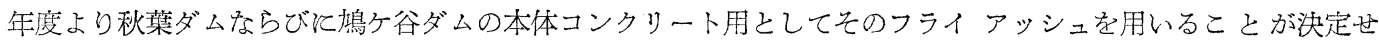
られるマいたつた。

本報告は，これらの一貫したアッシュ実用化研究のうち，主としてコットレル系フライアッシュの諸性質,な らびそそれがコンクリートの性質に招よぼす影響について述ベ，フライアッシュの実用上の一，二の問題を追 及し，汾砕フライ アッシュならびそポンド アッシュを用いた混合ポルトランドセメントについて記述する。

本研究を行うに当つて, 吉田德次郎先生より, 当初御激励を賜わり, 終始御秘䉆な御指導をいただいた。す た東京大学教授 国分正放博士，京都大学教授 近藤泰夫博士，大阪大学教授 安宅勝 博士の御教示をもいただ いた。試験の実施に当つては，関西電力 KK 常務取締役 一本松珠璣氏，同建設部長 目黒雄平氏より熱心な指導 監督を賜わつた。ここに諾えで御礼を申し上げる次第である。

本試験を担当した者は, 関西電力 $\mathrm{K} \mathrm{K}$ 建設部, 西井望雄, 中山謙治, 野網利雄, 小林正儿の 4 君で, 「フライ 
アッシュの吸着性試験」に関しては，特に野網，小林雨君の努力に負うところが大きい。また一部の試験実施に

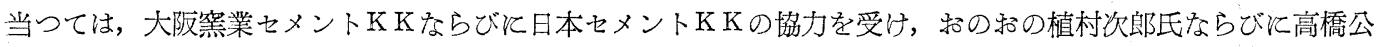
三氏をわずらわすところが大きかつた。

\section{II 概 説}

\section{〔1] ポゾラン混和材としてのフライ アッシュ}

ポゾランの使用は決して新しいものではない。ポゾランは，今から 2000 年以上も前飞火山灰 (Pozzuolana) と生石灰をセメント性材料として用いたローマ時代にさかのぼる。乙かし前世紀の前半林ルトランドセメン トが発明され，それが量産され普及するに和よんでポゾランの影はうすくなつてきた。ポゾランが新しい意義を あち, 再び脚光をあびるようそなつたのは比較的最近のことであつて，ポルトランドセメントの混和材として である。

セメント性材料としてポルトランド セメントのみを用いたモルタルまたはコンクリートは，酸またはある種 の塩の作用，特に硫酸塩の土によつて侵され，さらに普通の水々よつても分解される。また反応性の骨材を用い る場合には，ポルトランド セメント中のアルカリとの反応による破壊的な膨張が生ずる。ところが良質のポゾ ランを混和材として用いれば，コンクリートの化学的侵食に対する抵抗性をいちじるしく増し，コンクリート中 そ生ずる遊離石灰を減じて溶出の機会を少なくして，その耐透水性を増すとともに，特に近来いちじるしく問題 こなつたアルカり骨材反応対して有効な防止手段となることが明らかになつた。これがポゾラン登場の有力な 理由の一つである。

ポルトランド セメントは，その水和反応飞際してかなりの熱を発生する。とれがコンクリートの温度上显を

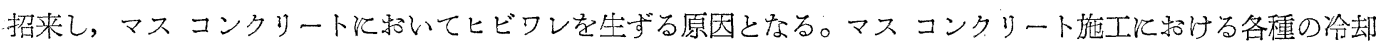
工法・ブロック工法などは，すべててのヒビワレ防止を眼目とするものであるが，その根本的な解決策の一つと してポゾランスよるポルトランド セメントの持きかが行われるようになつた。そしててれに付随してマスコ ンクリートの他の品質の改善ま行われることが明らかになつた。これがポゾラン登場の他の理由である。この点 をいま少し詳細検討してみる。

元来ダムのマス コンクリートは, 強度・水密性・耐久性などの所要の品質のみを問題とするならば，水セメ ント比より定ふる単位セメント量は一般にいわれている量 $\left(220 \mathrm{~kg} / \mathrm{m}^{3} \sim 180 \mathrm{~kg} / \mathrm{m}^{3}\right)$ 飞必ずしもしばられる必要 がない。しかし，これを下廻る単位セメント量では，所要のウォーカビリチーを確保し，プラスチシチーを維持 て，ブリージングその他材料の分離を制限するとと，つ末り適切な施工を実施することが困難であるとされてい る。いいかえれば，ダムのマス コンクリートでは，その品質を確保するための必要量以上のセメントを，施工 のためと用いなければならない状況である。

このことは, さらに，カロリ一源としてのセメントのために，ブロック工法ならびそ冷却工法（自然拉よび人 工の）など，一連の余分なヒビワレ防止の工法を課してきたとみるととができる。マスコンクリートに特ける ポゾランの混和使用は，それだけカロリ一源であるセメントの使用量を減じ，乙かも，所要の品質をそこなうこ となく, むしろ, この品質を向上しながら，コンクリートのウォーカビリチーを增大し，ブリージングやコンク リートのあらあらしさを制限することができることを明らかてした。この間，ポゾランの使用についで，AEコ ンクリートの研究も逐次展開された。A Eコンクリートは, そのコンクリートのウォーカビリチー・プラステシ チー・ブリージング・強度・凍結融解汶対する耐久性などに挌ける特性が明らかになるとともに，マスコンク リートに採用されるに至つたが，マスコンクリートに和けるA E 剤使用の要点は，他のコンクリート飞招ける ように，凍結融解対する耐久性を眼目とするものではなく、コンクリートに適当量のエントレインドエアーを もちこめば，ウォーカビりチーを改善し，ブリージングを制限することができるからであるとされている。この ことは，AE骩を用いることによつて，従来施工のためにのみ必要とされていた余分のセメントを使用する根抛 をなくすることが可能となつたことを意味するものである。A E 刘を用い，同時林ゾラン混和材によつてセメ

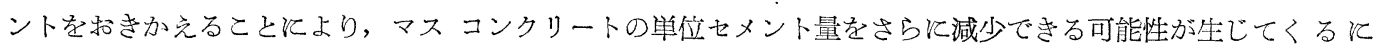
至つた。一方, ダム コンクリートの施工設備の機械化は, 急速に進歩し, 施工速度のいらじるしい高度化を来 した。ここに扔いてマス コンクリートのリフト・施工期間の短縮ならびそブロックの拡大などが企図され，こ れが A E 骫䄸よびポゾラン混和材の併用によつて，大幅低減された単位セメント量を通じて，実施の根搀をう ることとなつた。ダム建設は, 近時工期の短縮が要求される傾向が強い。これらはポゾラン湿和材の使用を大幅 飞要求するとととなつた有力な根拠である。 
ポゾラン混和材登場の第三の理由は経済性にある。各種のポゾラン混和材は，一般とポルトランド セメント よりも安い。いいかえればセメントより安いことがポゾラン混和材としての条件の一つである。従つて，ポゾラ ンでセメントの一部を和きか光使用することによつて，一次的にコンクリートの単価を低減し，コークリートの 施工上のブロック工法・冷却工法などの手間をはぶくことにより二次的飞工費を節約し，さらにコンクリートの 品質を改善することによつて終局的にコンクリートの経済性にひ益する。

ポゾラン混和材の使用がいちじるしく盛えになつたのは, 第二次大戦中およびその後のことであつて, 世界は あげてセメントの供給不足に悩まされた。この空気に刺笺されてマスコンクリートの単位セメント量をその品 質をそこなうことなく低減しようとする広範な研究が行われた。この間の事情は Bureau of Reclamationのダ ムを年代順湴べた表一2.1亿見ると和りである。

\section{表-2.1 Bureau of Reclamation におけるポゾランの使用}

\begin{tabular}{|c|c|c|c|c|c|c|}
\hline \multirow{2}{*}{ タムの名称 } & \multirow{2}{*}{$\begin{array}{c}\text { 高 さ } \\
\text { (m) }\end{array}$} & \multirow{2}{*}{$\begin{array}{c}\text { 堤 体 積 } \\
\left(\mathrm{m}^{3}\right)\end{array}$} & \multirow{2}{*}{ 工事期間 } & \multirow{2}{*}{$\begin{array}{l}\text { セメントト性材料 } \\
\text { 使用量 }\left(\mathrm{kg} / \mathrm{m}^{3}\right)\end{array}$} & \multicolumn{2}{|l|}{ ポゾ ラ } \\
\hline & & & & & 種 & $\begin{array}{c}\text { 才キ力工率 } \\
(\%)\end{array}$ \\
\hline Arrowrock & 108 & 487000 & $1911 \sim 1915$ & 214 & 粉砕花峷 岩 & 45 \\
\hline Elephant Butte & 92 & 482000 & $1911 \sim 1916$ & 223 & 粉 砕 砂 岩 & 48 \\
\hline Hoover & 221 & 2480000 & $1931 \sim 1936$ & 223 & 使 用世 ず & - \\
\hline Grand Coulee & 168 & 8100000 & $1933 \sim 1942$ & 223 & 使 用 せ ず & - \\
\hline Shasta & 184 & 5000000 & 1938 1945 & 223 & 使 用 せ ず & - \\
\hline Bonneville & 44 & 380000 & $1935 \sim 1936$ & 201 & 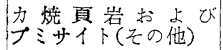 & 25 \\
\hline Friant & 97 & 1630000 & $1939 \sim 1942$ & 216 & プミサ & 17 \\
\hline Altus & 34 & 53700 & $1941 \sim 1945$ & 196 & ブ ミ サ & 26 \\
\hline Hungry Horse & 159 & 2220000 & $1948 \sim 1952$ & 164 & フライアッンュ & 32 \\
\hline Canyon Ferry & 67 & 300000 & $1949 \sim 1953$ & 140 & フライアッンュ & 32 \\
\hline Monticello & 90 & 200000 & $1953 \sim$ & 140 & フティ アッン二 & 28 \\
\hline Yellowtail & 156 & 1340000 & $1953 \sim$ & 140 & フライ アッン = & 30 \\
\hline
\end{tabular}

さて，フライアッシュは，他のポゾラン混和材に比して次の点が特に優れている。

（1）良質のフライ アッシュは，乙れをコンクリートに用いることによつてコンクリートの単位水量を減少す ることができる。これは他のポゾラン混和材には見られない特徴であつて，ポゾラン活性がほぼ同程度の材料に ついて水セメント・ポゾラン重量比で定まるコンクリートの性質を問題にするならば，単位セメント量を減少す ることができる。また単位水量を一定にするならば，コンクリートまたはモルタルのウォーカビりチー・ポンプ アビリテーなどをいちじるしく大きくすることができる。

（2）他のポゾラン混和材に比していちじるしく有利な生産条件をもつている。すなわち，フライアッシュは 石炭の然燒熱の利用ということから生ずる副産物で，元来は廃物である。フライ アッシュはポゾランとして採 掘・運船・集積の費用を要せず，またポゾラン活性を与えるためと特と烇く費用を要せず，さらに粉砕の費用も いらない。

以上のような背景のもとに，ポゾランとしてのフライ アッシュは戦後実用の時代に入つたのである。

\section{[2]火力発電所の概況および搭灰}

わが国火力発電設備の大半をもつ関西地区を例ととつて，火力発電所の概況招よび捨灰について記述する。関 西地区火力発電の設備能力は 表一2.2 のと预りで, 建設中の 2 発電所を含めて 138 万W $\mathrm{k}$ 達し, その年間消費 石炭量は 150 万七怙よんでいる。これらの火力発電所のうちにはいわゆる老朽火力も含まれているが微粉炭然 焼方式をとる新鋭火力は 5 力所 79 万 $\mathrm{kW}$ である。

これらの火力発電所江用いる石炭は九州炭拉よび北海道炭を主とし, その平均品位は $6000 \mathrm{kcal} / \mathrm{kg}$, 灰分 $22 \%$ で，火力発電所の年間の捨灰の生成量は 30 万を越すすのとみられる。これらの灰は集積して処理しなければ ならないが，一部は埋立地の築造に使用し，他は船積して海に廃较し，漁業との間に問題を生じ，あるいは，発 電所近傍の田畑をつぶしてこれと搭てることもある。このようと火力発電所の捨灰々要する費用は必ずしも小さ いものではない。

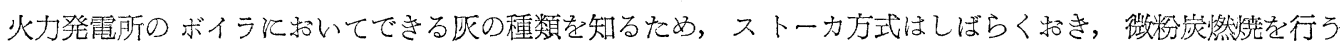
尼ケ崎第二火力発電所を例にとつてみる。図一2.1 はとのボイラの見取図であつて, ミルで粉砕された $200 x$ ッシュ通過 $85 \%$ の石炭は, 空気とともに邩の中送られる。この石炭は, 微粉岸バーナから出るとあたかもガ 


\section{図一-2・1尼ケ崎第二発電所ボイラ縦断図}

汽圧: $43 \mathrm{~kg} / \mathrm{cm}^{2}$

汽温 : $445^{\circ} \mathrm{C}$

最大蒸発量: $200 \mathrm{t} /$ 時

伝熱面積: $1215 \mathrm{~m}^{2}$

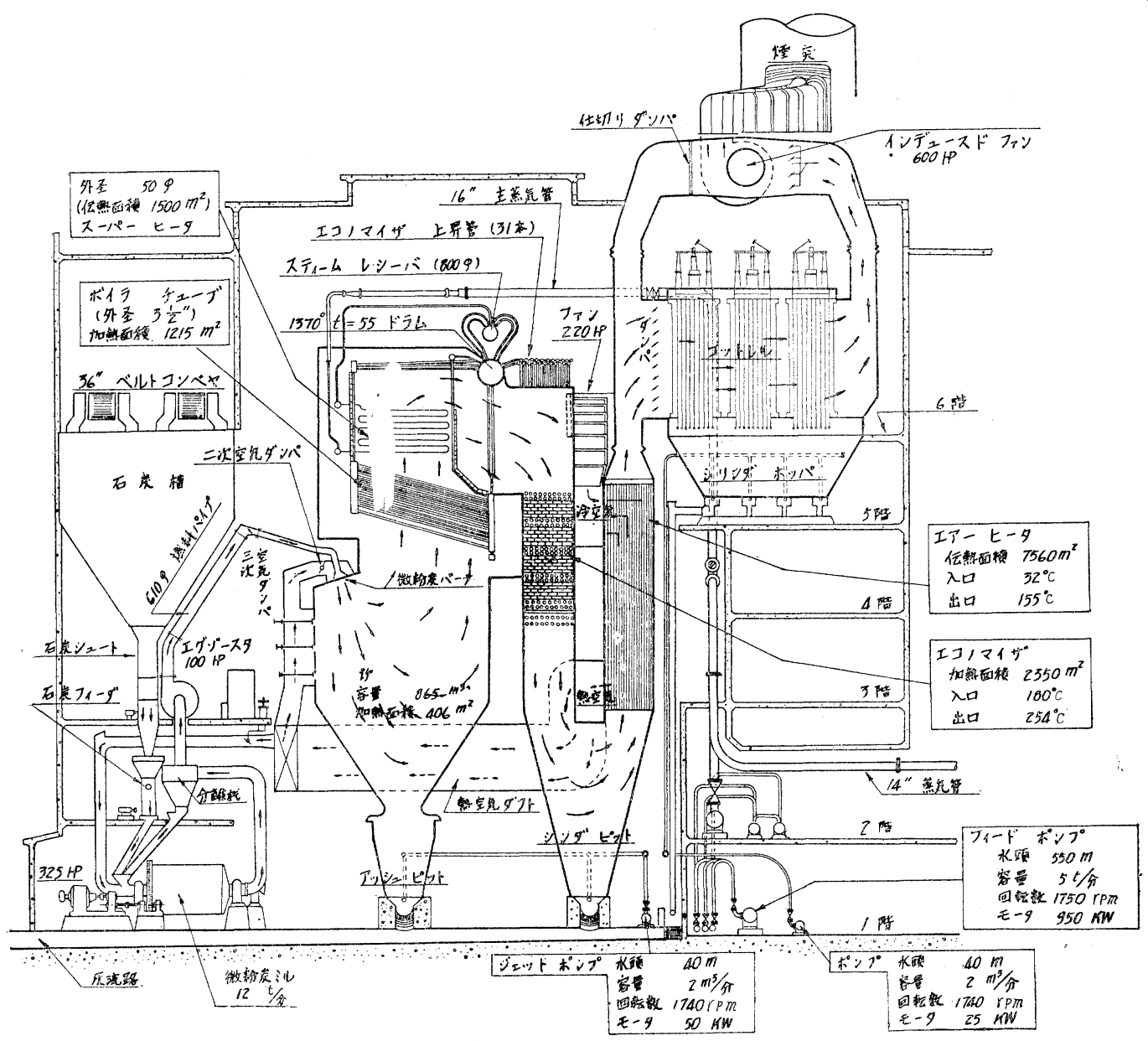

ス体のようと瞬時飞点火し, 長大な焰を形成して然焼する。炬内の温度は $1400^{\circ} \mathrm{C}$ を越し, 石炭中の灰分が溶ゆ うするのに十分である。兏の受ける作用は，火山灰の受ける作用ににていると考觉られている。溶ゆうした灰は， その表面張力によつて小さな球状になり，熟気乗せられて運ばれる。この間，あるものは互い衝突してとの 盖径を増しあるものは炉壁に付着する。熱気は，ボイラテューブ・スーパヒータ・エコノマイザ・エアーヒ 一タなどを通過し，集麾器を経て煙突に至る。これらの間で所定の熱交換が行われて，スチームを作るととも そ, 熱気は, 急速飞冷却され，溶ゆう状態にあつた灰の粒子は，急激に固化してガラス質となる。

この一系統の操作のうちで石炭の不然分である灰は, (1) 炬の直下にあるアッシュピット, (2) エコノマイザよ

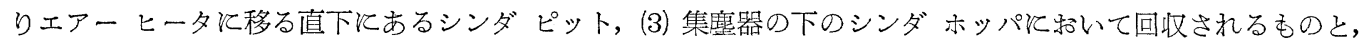
さらに (4) それらに捕捉されず飞抜け出す煙と分けられる。(1)(2)(3)の灰をそれぞれアッシュクリンカ，シン ダ アッシュおよびフライ アッシュと呼ぶことにする。アッシュクリンカは, 炣壁飞付着した溶ゆう状態のアッ シュの層がある厚さに達したとき, 自重によつてピット内の水落下したものが主体であつて, 塊状のアッシュ である。シンダ アッシュは, 気流の方向変換の際振り切られるアッシュの粒子であつて, $5 \sim 0.5 \mathrm{~mm}$ 程度の ものが多い。フライ アッシュはシンダ アッシュより細かいもので，その粒度分布は集暨方式によつて相違す る。フライアッシュの集榣方式には, 電気的方式一 あるコットレルと機械的方式であるサイクロン・ローテミ ユーレなどがある。フライ アッシュは，とれらの：蝔方式によつて，コットレル系フライ アッシュとサイクロ ン系フライ アッシュに大別することができる。各 アッシュの大略の量的な割合は 表一2.3 のと和りである。 
表一2.2 関、西 電 力 祩 式 会 社

\begin{tabular}{|c|c|c|c|c|c|c|c|c|c|c|}
\hline \multirow{2}{*}{ 発電所名 } & \multirow{2}{*}{ 所在地 } & \multirow{2}{*}{ 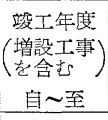 } & \multirow[b]{2}{*}{$\begin{array}{c}\text { 認可出力 } \\
(\mathrm{kW})\end{array}$} & \multirow[b]{2}{*}{$\begin{array}{c}\text { 年間発生䉓力量 } \\
\text { (k.W.H) }\end{array}$} & \multicolumn{3}{|c|}{ 汽 } & 出 & \multirow{2}{*}{ 燃烍装置 } & 集麾 \\
\hline & & & & & 数 & $\begin{array}{l}\text { 缶数一汽圧 } \\
\left(\mathrm{kg} / \mathrm{cm}^{2}\right)\end{array}$ & $\begin{array}{c}\text { 汽 温 } \\
\left({ }^{\circ} \mathrm{C}\right)\end{array}$ & $\begin{array}{c}\begin{array}{c}\text { 岳数一蒸発量 } \\
(\mathrm{t} / \text { 時 })\end{array} \\
\end{array}$ & & 型式 \\
\hline 宫津 & 亳都府与謝郡 & 1936 & 13000 & $\begin{array}{llll}50 & 387 & 100\end{array}$ & 4 & 32 & 415 & 32.0 & 移 床 & \\
\hline 琴浦 & 秏歌山再 & $1922 \sim 40$ & 14000 & 13657300 & 8 & 15.46 & 366 & $\begin{array}{l}4-12.56 \\
4-17.00\end{array}$ & 鎖 床 & \\
\hline 堺 & 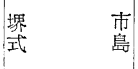 & $1927 \sim 35$ & 21000 & 73643300 & 5 & 22.5 & 400 & 52.0 & 移 林 & \\
\hline 木 津 川 & $\begin{array}{l}\text { 大阪市住喜区 } \\
\text { 加資町 }\end{array}$ & 1928 & 63000 & 142757900 & 8 & 28.0 & 366 & $\begin{array}{l}4-60 \\
4-74\end{array}$ & $\begin{array}{l}\text { 4-㥎粉焚 } \\
\text { 4一微粉 }\end{array}$ & コットレル \\
\hline 福崎 & 太阪市港区: & $1920 \sim 23$ & 36000 & 2333200 & 11 & $\begin{array}{l}7-17.6 \\
4-18.3\end{array}$ & 333 & 28.6 & 下 迅 & \\
\hline 春日出第二 & $\begin{array}{l}\text { 大阪市此花区 } \\
\text { 北安治川通 }\end{array}$ & $1922 \sim 38$ & 65000 & 29829700 & 32 & 15.8 & 316 & $\begin{array}{r}4-17.6 \\
28-15.0\end{array}$ & $\begin{array}{cc}6-下 & \text { 这 } \\
26 \text { 一鎖 } & \end{array}$ & \\
\hline 安 治 川 & 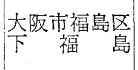 & 1938 & 16000 & 44762400 & 3 & 33 & 430 & 48 & $\begin{array}{l}\text { 1-鎖 㷊 } \\
\text { 㷊 }\end{array}$ & コットレル \\
\hline 尼ヶ崎束 & 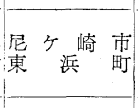 & $1924 \sim 28$ & 140000 & 114677900 & 16 & 20.4 & 334 & $\begin{array}{l}4-45.5 \\
4-52.3 \\
4-62.5 \\
4-75.0 \\
\end{array}$ & 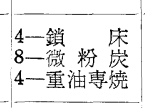 & コットレル \\
\hline 尼ケ崎第一 & 腒ヶ崎市 & $1933 \sim 36$ & 318000 & 763747000 & 12 & 42 & 445 & 145 & 徽粉炭 & $\begin{array}{l}\text { コットレル } \\
\text { マルギ サイグ } \\
\text { タブル サイクロン }\end{array}$ \\
\hline 尼ケ崎第二 & 柎公崎 & $1937 \sim 53$ & 300000 & 1103845000 & 11 & 43 & 445 & 200 & 微粉崖 & 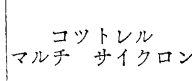 \\
\hline 颂 川 & $\mid$ & $1922 \sim 25$ & 12500 & $\begin{array}{lll}1 & 661 & 100\end{array}$ & 8 & 17.5 & 380 & 14 & 移 林 & \\
\hline 飾 磨 港 & 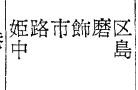 & $1932 \sim 53$ & 75000 & 258395400 & 7 & $\begin{array}{l}6-46 \\
1-47\end{array}$ & $\begin{array}{l}400 \\
410\end{array}$ & $\begin{array}{l}4-56.8 \\
2-63.5 \\
1-16.0\end{array}$ & 微粉崖 & $\begin{array}{l}\text { シンダル サイクロ } \\
\text { ンローテミューV }\end{array}$ \\
\hline 綱 干 & 姫 路市綱干酒干 & $1927 \sim 37$ & 20000 & 35995900 & 6 & 17.6 & 375 & $\begin{array}{l}4-18.1 \\
2-34.0\end{array}$ & 鎖 床 & \\
\hline (多奈川) & 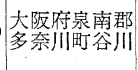 & $\begin{array}{l}\text { 㛏設中 } \\
\text { (1956) }\end{array}$ & 150000 & $\left(\begin{array}{lll}788 & 000 & 000\end{array}\right)$ & 2 & 103 & 543 & 254 & 微粉㛶 & サイクロン \\
\hline (姫 路) & 姫路市飾磨区 & $\mid \begin{array}{c}\text { 建設中 } \\
(1955 \sim 57)\end{array}$ & 141000 & $\left(\begin{array}{lll}741 & 200 & 000\end{array}\right)$ & 3 & $\begin{array}{l}2-63 \\
1-92\end{array}$ & $\begin{array}{l}2-490 \\
1-515\end{array}$ & $\begin{array}{l}2-150 \\
1-270\end{array}$ & 微粉孷 & $\begin{array}{l}\text { マルチ期イクロン } \\
\text { (第二分未定) }\end{array}$ \\
\hline 合 計 & (建設中を) & & $\left.\begin{array}{lll}1 & 093 & 500 \\
(1 & 384 & 500\end{array}\right)$ & $\left|\begin{array}{rrrr}2 & 635 & 693 & 500 \\
(4 & 164 & 893 & 500)\end{array}\right|$ & & & & & 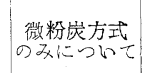 & 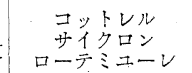 \\
\hline
\end{tabular}

表一2・3 微粉崖燃焼を行う火力発電所のアッシュ分類表

\begin{tabular}{|c|c|c|c|c|c|c|}
\hline & アッシコ名称 & 分 類 & 採 取 場 所 & アッシュの大きさ & 生 成 状 態 & $\begin{array}{l}\text { 生成割合 } \\
(\%)\end{array}$ \\
\hline 1 & クリンカ アッシュ & 塊 状 & アッシュピット & $5 \mathrm{~mm}$ 以上 & $\begin{array}{l}5 \mathrm{~mm} \text { 以上の粒状ょ } \\
\text { 上び不規則な塊状 }\end{array}$ & $20 \sim 30$ \\
\hline 2 & シンダアッン: & 粗 粒 部 & シンダピット & $5 \sim 0.5 \mathrm{~mm}$ & 稙 状 & $15 \sim 25$ \\
\hline 3 & フライアッシュ & 細 粉 部 & 集塺 & $0.5 \mathrm{~mm}$ 以下 & 状 & $40 \sim 50$ \\
\hline 4 & 煙 & & & & & $8 \sim 12$ \\
\hline
\end{tabular}

これら各種のアッシュは，ピット抒よびホッパ飞招いて捕捉回収すると，ただちに水で流送する方式をとるこ とが多い。これは, 火力発電所の清橴維持のためであつて, 火力発電所は, 電気の生産工場であつて, アッシュ 
火力 発電設備一覧 表

\begin{tabular}{|c|c|c|c|c|c|c|c|c|c|c|}
\hline & 汽 & 機 & 発 & 電＼cjkstart機 & 然 & & 料 & & & \\
\hline $\begin{array}{l}\text { 設備—個/缶 } \\
\text { 缶数 }\end{array}$ & 数 & $\begin{array}{c}\mid \text { 缶数一定格 } \\
(\mathrm{wW}) \\
\end{array}$ & 数 & 容 $(\mathrm{k} . \mathrm{V} . \mathrm{A})$ & 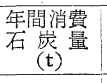 & $\begin{array}{l}\text { 発 熱 } \\
(\mathrm{kcal} / \mathrm{g} \\
\mathrm{9g})\end{array}$ & ${ }^{\sqrt{2}}(\%)^{\text {分 }}$ & $\mid(\mathrm{kg} / \mathrm{kWH} \mid$ & 戻 捨 装 & 考 \\
\hline \multirow[t]{3}{*}{$4-1$} & 2 & 13000 & 2 & 12500 & 35149 & 5867 & 25.0 & 0.697 & 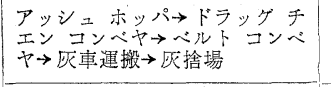 & \\
\hline & 2 & 7000 & 2 & 8750 & 12893 & 6148 & 21.8 & 0.944 & 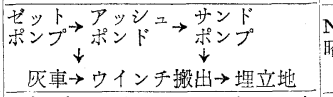 & $\begin{array}{l}\text { No. } 1,2, \mathrm{~B} \\
\text { 昭和 } 28.9 .1 \\
\text { 休止 }\end{array}$ \\
\hline & 4 & $\begin{array}{ll}2-7 & 000 \\
1-12 & 500 \\
1-10 & 000\end{array}$ & 4 & $\begin{array}{rr}2-8 & 750 \\
1-15 & 625 \\
1-12 & 500 \\
\end{array}$ & 55849 & 6224 & 20.9 & 0.758 & 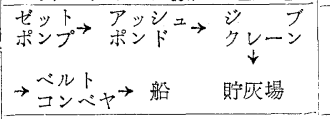 & \\
\hline \multirow[t]{3}{*}{$2-1$} & 2 & 31500 & 4 & $\begin{array}{rl}2-37 & 500 \\
2-2 & 140 \\
\end{array}$ & 72950 & 6189 & 21.1 & 0.746 & アッシュホッパ & \\
\hline & 4 & 10000 & 4 & 12500 & 2492 & 5822 & 25.8 & 1.064 & アッンュ ホッパ 灰車 & $\begin{array}{l}\text { No. } 1,2, \mathrm{~T} \\
\text { No.4 7B } \\
\text { 昭和 } 28.9 .1 \\
\quad \text { 休止 } \\
\end{array}$ \\
\hline & 3 & $\begin{array}{ll}2-20 & 000 \\
1-25 & 000\end{array}$ & 3 & $\begin{array}{ll}2-25 & 000 \\
1-30 & 000\end{array}$ & 25705 & 6351 & 18.9 & 0.861 & 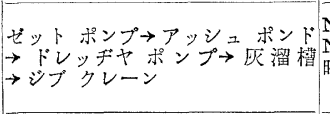 & $\begin{array}{l}\text { No.1,2, T } \\
\text { No.17 32B } \\
\text { 昭和 } 28.9 .1 \\
\quad \text { 休止 }\end{array}$ \\
\hline $3-2 / 3$ & 1 & 18500 & 2 & $\begin{array}{rr}1-18 & 750 \\
1-1 & 430\end{array} \mid$ & 30770 & 5993 & 22.6 & 0.685 & 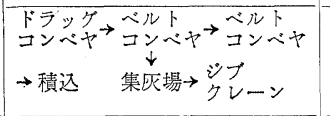 & \\
\hline $4-1 / 2$ & 7 & $\begin{array}{ll}4-25 & 000 \\
1-40 & 000 \\
1-1 & 000 \\
1-1 & 000 \\
\end{array}$ & 7 & $\begin{array}{ll}4-25 & 000 \\
1-43 & 750 \\
1-1 & 500 \\
1-6 & 250 \\
\end{array}$ & 80408 & 6126 & 21.5 & 0.891 & 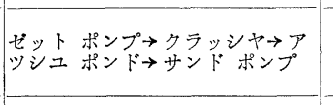 & \\
\hline $\begin{array}{l}3-1 \\
4-1 \\
5-1\end{array}$ & 6 & 53000 & 8 & $\begin{array}{l}4-62500 \\
4-4290\end{array}$ & 440350 & 6123 & 21.6 & 0.618 & 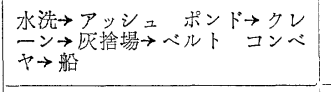 & \\
\hline \multirow[t]{2}{*}{$\begin{array}{l}9-1 \\
2-1\end{array}$} & 4 & 75000 & 4 & 93750 & 594565 & 6151 & 21.7 & 0.572 & 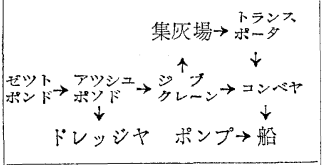 & \\
\hline & 2 & 12500 & 2 & 15625 & 2397 & 5917 & 22.0 & 1.440 & $\begin{array}{l}\text { ホッパースクレーパートロ高コ } \\
\rightarrow \text { 艀船 }\end{array}$ & \\
\hline \multirow[t]{2}{*}{$\begin{array}{l}6-2 \\
1-1\end{array}$} & 3 & 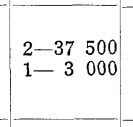 & 3 & 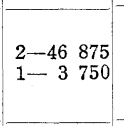 & 143131 & 6080 & 23.1 & 0.621 & 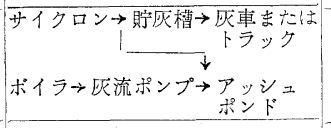 & \\
\hline & 3 & $\begin{array}{ll}1-10 & 000 \\
2-12 & 500\end{array}$ & 3 & $\begin{array}{ll}1-12 & 500 \\
2-15 & 625\end{array}$ & 27895 & 6068 & 21.3 & 0.774 & 灰車手押 & \\
\hline $2-2$ & 2 & 75000 & 2 & 93750 & $(392000)$ & $\left(\begin{array}{ll}5 & 300\end{array}\right)$ & & $(0.497)$ & 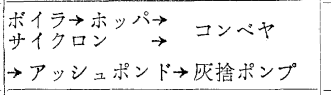 & \\
\hline $2-1$ & 2 & $\begin{array}{l}1-66000 \\
1-75000\end{array}$ & 2 & $\left|\begin{array}{ll}1-81 & 176 \\
1-88 & 235\end{array}\right|$ & $\left(\begin{array}{ll}408 & 000\end{array}\right)$ & $\left(\begin{array}{ll}5 & 300\end{array}\right)$ & & $(0.550)$ & $\begin{array}{l}\text { ホッパ } \rightarrow \text { ब流溝 } \rightarrow \text { ब流海水ポンプ } \\
\rightarrow \text { 皮 } \\
\text { 立地 }\end{array}$ & \\
\hline $\begin{array}{l}18 \\
17(21) \\
1\end{array}$ & & & & & $\left|\begin{array}{lll}1 & 524 & 554 \\
(2 & 324 & 554\end{array}\right|$ & & & & & \\
\hline
\end{tabular}

の生産工場ではないという立場がとられているからである。流水で送られる各種のアッシュは，これを集めてア ッシュポンドに運び，ここでアッシュを沈でん集積して処理するのが普通である。アッシュポンドで得られる アッシュは, 前述したアッシュクリンカ・シンダ アッシュ・フライ アッシュの混合物であつて，これを便宜 上ポンド アッシュと呼ぶ。

以上アッシュの種類を尼ヶ崎第二火力発電所について述べたが，ボイラ構造・集麿方式の異なると従つてアッ シュの種類・量も多少は異なる。しかしその内容は大差ないと考光てょい。いまアッシュ利用の立場より各発電 所のアッシュを見ると，発電所汇よつてその対象となるアッシュの種類む異なるが，これを大別して，(1)コット レル系フライ アッシュ，(2)サイクロン系フライ アッシュ，(3)ポンドアッシュの3つとすることができる。そ してこの 3 種のアッシュとついて扔の扮の利用の方途をうるならば，火力発電所のすべての捨灰について利用の 途をつけたといいうる。 


\section{[3]試験研究の目的之範囲}

前節の記述より知りうるように, 微粉炭然燒を行う新鋭火力に招けるアッシュの大半はフライアッシュの形 で回収される。本試験研究は, 火力発電所のアッシュ全体のポゾラン混和材としての有効利用を目的としたもの であるが，上記の理由によつてフライ アッシュの研究に主力を注ぐとととなつた。

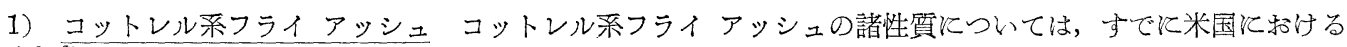
諸家の研究があるので実用化研究の主力は，米国特よびわが国の石炭の相違・発電所設備の相違なぞを考慮して フライアッシュの性質の試験に扔いた。またわが国のセメントを用いたコンクリートに及ぼす各種の性質につ いて試験し，同時にフライアッシュをA Eコンクリートに使用する場合に生ずる問題について新しい研究を行 つた。さらにフライアッシュの採取設備の改造に関する指針をうるととるに，フライアッシュの試験方法なら び代様の検討も行つた。

2）ポンドアッシュポンドアッシュをポゾラン混和材として使用するととを目嘌として，そのポゾラン活 性・粉确方式を研究するとともに，これをセメントクリンカとともにミルで粉砕して混合ポルトランド セメン トとして利用することを研究し，その試験方法抢よび仕様について検討した。

3）サイクロン系フライアッシュサイクロン系フライアッシュは, 種々試験の結果, フライアッシュと してそのまま用いるの沽適当でないととが明らがなつたが，サイクロン系のものは，コットレル系のものに比 較して, その設備が多く回収量も大きいので, これを粉砕して利用することを研究した。この際フライアッシ 二粒子の琲形を破壊する範囲を必要最小限飞とどめるため, 差別粉能のできる粉碎方式を用いて検㑏を行つた。 ポゾラン活性・所要水量比の試験とともに, 粉砕フライ アッシュを用いたコンクリートの強度試験との他を行 つた。

\section{III コットレル系フライ アッシュの化学的ならびに物理的性質}

\section{〔1]フライ アッシュ}

コットレル系フライアッシュの試験注尼ケ崎第二火力発電所を対象とした。実験期間の前半に执いては, フライアッシュはまだ水で流送されていたので，乾橾状態のままでフライアッシュを採取するためには，ボイ ラ運転休止のときを利用しなければならなかつた。当時, フライアッシュの試料採取に当つては，それれさき

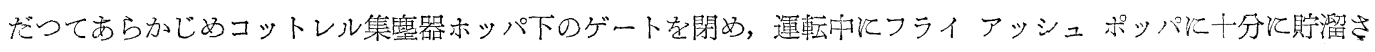
せて招き，運転休止後にとれらを採取した。このようとして採取するフライアッシュは，本質的にはボイラ運 転中に採取するフライアッシュとなんら相違するところはないが，ただホッパ下のゲートを閉めるのがやや渥 く運転休止のほとえど直前に行われる場合には，ボイラ運転休止直前の燃燒不調の影響がフライアッシニに現 われるのを避けることができなかつた。しかし，このととを利用して品質の異なるフライアッシニを随時採取 し，フライアッシュの品質の相違がコンクリートの諸性質に技よぼす影響を実験し，フライアッシュの変動の 範团を把握するとともできた。実験期間の後半では，フライアッシュ採取用仮設備が整備されたのでボイラ渾 転中に試料を採取した。

試料は，笑験期間の前半ではコットレル集覻器をむつ1号〜 9号の全 9 岳のボイラより採取し，後半では採取 設備の関係で 5 号年拉よび 6 号缶のみより採取した。

試験飞用いた試料フライアッシュは総計約 60 種に招よぶが, そのうち本報告で述べるものは 36 種であり，そ の内訳はボイラ運転休止中に採取したものが 18 種, 運転中に採取したものが 18 種である。これらのうち, 直接 コンクリート実験に供したものは主として前者のフライアッシュである。これらのフライアッシュの拉もな性 質は 表一3・1 と示すと招りである。

\section{[2]試験方法}

フライアッシュの物理的・化学的性實の試験方法のうち, 特に検討したものをあげれば次のと㧍りである。

1. 比重試験方法 比重試験は, JIS R5201 (セメントの物理試験方法) 飞準じて行つた。ただし試料は $70 \mathrm{~g}$ とし，フライ アッシュを比重ビンに入れ終つてから液面の目盛を読むまでの時間は，気泡を完全に追い出すた め, 約 24 時間以上と乙た。気泡を完全飞追い出すのにこのよう飞長時間を要するのは, 後述のようにフライア ッシュ粒子がある程度の空隙をそれ自体の中有するためであると思われる。

2. 粉末度試験方法 フライアッシュの粉末度は, $88 \mu$ フルイ残分の試験・44 4 フルイ残分の試験・ブレー ン方法による比表面積の測定・比重計（浮ハカリ）方法による粒度分析㧍よび比表面積の測定など各種の方法に よつて行つた。 
表一3・1 試験に用いたフライ アッシュのおるな性質

\begin{tabular}{|c|c|c|c|c|c|c|c|c|c|c|c|c|c|c|c|c|c|c|}
\hline \multirow{2}{*}{$\begin{array}{l}\text { フライ } \\
\text { アッシ } \\
\text { = }\end{array}$} & \multirow[b]{2}{*}{ 採取日時 } & \multirow{2}{*}{\multicolumn{2}{|c|}{ 採 取箇 所 }} & \multicolumn{2}{|c|}{ 化 } & & \multicolumn{2}{|r|}{ 成 } & \multicolumn{3}{|c|}{ 分 $(\%)$} & \multirow[b]{2}{*}{ 比重 } & \multicolumn{2}{|r|}{ 粉 } & & \multicolumn{2}{|c|}{ 度 } \\
\hline & & & & $\mid \begin{array}{l}\text { シリカ } \\
\left(\begin{array}{ll}\left.\mathrm{S}: \mathrm{O}_{2}\right)\end{array}\right)\end{array}$ & $\begin{array}{l}P ル ミ+~ \\
\left(\mathrm{Al}_{2}\right. \\
\left.\mathrm{O}_{3}\right)\end{array}$ & 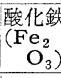 & 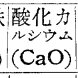 & $\begin{array}{l}\text { マグネ } \\
\text { シア } \\
\text { CMrO }\end{array}$ & $\mid \begin{array}{l}\text { 無水硫 } \\
\text { 䟲 } \\
\left(\mathrm{SO}_{3}\right)\end{array}$ & $\begin{array}{l}\text { 炭 素 } \\
\text { (C) }\end{array}$ & $\begin{array}{l}\text { 強 暬 } \\
\text { 減 } \\
\end{array}$ & 合計 & & $\begin{array}{l}88 \mu \text { ᄀ } \\
\mu \text { 个残 } \\
\text { 分 }(\%) \\
\end{array}$ & $\begin{array}{l}44 \mu \text { 足 } \\
\sim \sim \text { 残 } \\
\text { 分 } \% \text { ) }\end{array}$ & $\begin{array}{l}\text { ブレーン } \\
\text { 此表面栍 } \\
\left(\mathrm{cm}^{2} / \mathrm{g}\right)\end{array}$ & $\begin{array}{l}\text { 比重計方法 } \\
\text { 比表面積 } \\
\left(\mathrm{cm}^{2} / \mathrm{g}\right)\end{array}$ & $\begin{array}{l}10 \mu \text { 以 } \\
\text { 下の粒 } \\
\text { 子 }(\%)\end{array}$ \\
\hline A & 5.25 .1953 & $\begin{array}{c}\text { 尼 }-2= \\
8\end{array}$ & 总卜年 & 57.6 & 27.3 & 7.0 & 3.8 & 2.3 & 0.3 & 0.9 & 1.6 & 99.9 & 2.13 & 1.8 & 12.0 & 3680 & 2560 & 28.2 \\
\hline $\mathrm{A}^{\prime}$ & " & & " & 57.6 & 27.1 & 3.9 & 3.2 & 2.5 & 0.5 & 0.9 & 1.6 & 96.3 & 2.09 & 2.0 & - & 3440 & - & - \\
\hline B & " & 9 & 号 缶 & 57.1 & 27.2 & 6.4 & 3.8 & 2.2 & 0.5 & 1.7 & 2.4 & 99.6 & 2.08 & 2.3 & 18.0 & 3270 & 2270 & 23.4 \\
\hline C & " & & " & 55.7 & 25.8 & 6.8 & 3.4 & 2.4 & 0.6 & 2.5 & 3.0 & 97.7 & 2.09 & 5.2 & 22.8 & 3240 & 2150 & 21.1 \\
\hline D & 1. - 1953 & & - & 59.0 & 28.2 & 5.2 & 3.3 & 1.9 & 0.4 & 0.7 & 2.0 & 99.9 & 2.05 & 3.5 & 15.3 & 2660 & 1600 & 12.1 \\
\hline$E$ & 5.22 .1953 & 5 & 号 缶 & 59.2 & 25.7 & 6.6 & 3.7 & 1.6 & 0.4 & 2.2 & 2.6 & 99.7 & 2.12 & 8.3 & 26.2 & 3110 & 2080 & 20.4 \\
\hline F & 5. 9.1953 & 6 & " & 58.2 & 28.1 & 5.4 & 3.7 & 1.8 & 0.5 & 1.5 & 1.9 & 99.7 & 2.04 & 10.2 & 38.4 & 2750 & 1540 & 15.1 \\
\hline G & " & 5 & " & 56.7 & 27.7 & 5.4 & 3.8 & 1.9 & 0.7 & 3.0 & 3.9 & 100.0 & 1.96 & 13.2 & 40.8 & 2280 & 1170 & 5.6 \\
\hline $\mathrm{H}$ & " & 6 & $"$ & 58.8 & 27.9 & 5.8 & 3.1 & 1.6 & 0.5 & 1.4 & 1.9 & 99.7 & 2.01 & 14.6 & 42.4 & 2410 & 1370 & 11.0 \\
\hline I & $"$ & 5 & " & 58.4 & 27.5 & 2.7 & 3.1 & 2.2 & 0.6 & 3.4 & 4.3 & 98.7 & 1. 95 & 17.3 & 50.8 & 2000 & 1030 & 4.9 \\
\hline $\mathrm{J}$ & $"$ & 4 & " & 58.3 & 27.8 & 4.3 & 3.4 & 1.9 & 0.7 & 2.6 & 2.8 & 99.1 & 1.98 & 22.6 & 57.6 & 1800 & 820 & 1.2 \\
\hline $\mathrm{K}$ & 9. 9.1953 & 1 & " & 56.9 & 28.9 & 6.1 & 3.4 & 1.8 & 0.5 & 1. & 1.5 & 99.0 & 2.07 & 3.0 & 14.9 & 3180 & 2150 & 19.3 \\
\hline L & $"$ & 8 & $"$ & 53.7 & 28.1 & 5.9 & 5.7 & 2.8 & 0.8 & 0.5 & 1.3 & 98.2 & 2.08 & 4.3 & 18.2 & 2810 & 1890 & 15.3 \\
\hline M & " & 9 & " & 56.6 & 26.7 & 7.2 & 4.4 & 2.0 & 0.7 & 1.0 & 1.4 & 98.9 & 2.08 & 3.3 & 15.3 & 3290 & 2100 & 17.9 \\
\hline $\mathrm{N}$ & 1.28 .1953 & 5 & $"$ & 57.6 & 26.5 & 6.9 & 3.8 & 2.7 & 0.6 & 0.1 & 0.9 & 98.9 & 2.16 & 2.4 & 16.1 & 3460 & 2780 & 32.3 \\
\hline $\mathrm{O}$ & 5.22 .1953 & 9 & $"$ & 57.5 & 24.9 & 5.8 & 3.3 & 1.9 & 0.6 & 1.5 & 2.4 & 97.9 & 2.15 & 3.0 & 18.3 & 2940 & 1740 & 13.9 \\
\hline $\mathbf{P}$ & 4. 7.1954 & & - & 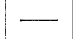 & - & - & - & - & 一 & - & 1.1 & - & 2.16 & 2.8 & 15.1 & 2700 & - & - \\
\hline Q & 3.22 .1954 & 8 & $"$ & 54.1 & 30.4 & 6.7 & 5.5 & 1.9 & 0.3 & 0.3 & 0.7 & 99.8 & 2.12 & 2.0 & 13.2 & 3620 & 2840 & 30.5 \\
\hline 628 & 6.28 .1954 & 5,6 & 号午混和 & 55.3 & 29.9 & 5.8 & 3.3 & 1.5 & 0.5 & $\ldots$ & 2.3 & 98.6 & 2.17 & 1.8 & 11.3 & 4540 & 3240 & 36.8 \\
\hline 630 & $6.30 . "$ & & " & 55.3 & 29.5 & 6.0 & 3.4 & 1.5 & 0.7 & - & 2.2 & 98.9 & .16 & 2.4 & 18.5 & 250 & - & 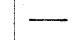 \\
\hline 72 & $7.2 . "$ & & " & 54.7 & 29.6 & 5.6 & 3.5 & 1.9 & 0.7 & - & 2.7 & 98.2 & 2.15 & 2.9 & 13.4 & 4560 & - & - \\
\hline 75 & $7.5 . "$ & & " & 54.2 & 29.2 & 6.1 & 3.3 & 1.9 & 0.7 & - & 2.2 & 97.8 & 2.11 & 2.5 & 13.8 & 4100 & - & - \\
\hline 77 & $7.7 . "$ & & $"$ & 55.6 & 28.9 & 5.4 & 3.4 & 1.7 & 0.8 & - & 2.5 & 98.0 & 2.13 & 2.3 & 17.0 & 4320 & 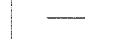 & - \\
\hline 79 & 7. $9 . "$ & & $"$ & 53.5 & 28.5 & 6.1 & 3.7 & 2.1 & 0.8 & $\longrightarrow$ & 2.2 & 96.9 & 2.15 & 3.0 & 10.0 & 4730 & 2860 & 33.4 \\
\hline 712 & 7.12 ." & & $"$ & 53.9 & 28.7 & 6.5 & 3.8 & 1.7 & 0.8 & - & 2.4 & 97.8 & .14 & 1.9 & 17.8 & 160 & - & - \\
\hline 714 & $7.14 . "$ & & $"$ & 53.3 & 30.6 & 5.8 & 3.9 & 1.5 & 0.7 & - & 2.0 & 97.8 & 2.14 & 1.9 & 13.7 & 4140 & - & - \\
\hline 716 & $7.16 . "$ & & " & - & - & - & - & - & - & - & 2.0 & - & 2.10 & 1.1 & 11.3 & 4050 & 3280 & 33.4 \\
\hline 721 & 7.21. " & & " & - & - & - & - & - & - & - & 2.3 & - & 2.13 & 1.3 & 12.0 & 4230 & 3040 & 35.0 \\
\hline 723 & $7.23 . "$ & 6 & 号 缶 & 56.3 & 28.6 & 5.4 & 4.5 & 1.5 & 0.2 & 1.2 & 1.9 & 98.4 & 2.09 & 2.5 & 13.6 & 3800 & 2910 & 30.4 \\
\hline 724 & $7.24 . "$ & & $"$ & - & - & $\ldots$ & - & 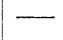 & 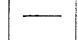 & 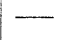 & 1.3 & - & .08 & 2.1 & - & 3430 & $\longrightarrow$ & - \\
\hline 730 & 7.30. & 5,6 & 号缶混和 & - & - & - & - & - & - & - & 2.1 & - & 2.06 & 2.2 & 8.7 & 3830 & 3010 & 35.3 \\
\hline 82 & $8 \cdot 2$. & & $"$ & - & - & - & - & $\ldots$ & 一 & - & 2.2 & - & 2.17 & 2.3 & 11.9 & 4120 & 3000 & 34.7 \\
\hline 89 & $8.9 . "$ & & $"$ & - & - & - & - & - & - & - & 2.3 & - & 2.13 & 2.4 & 13.2 & 4270 & 3340 & 36.4 \\
\hline 96 & $9.6 . "$ & & " & - & - & - & - & - & - & - & 1.8 & - & 2.12 & 2.6 & 10.6 & 4220 & 2780 & 33.0 \\
\hline 1115 & $11.15 . "$ & 5 & 号 缶 & - & - & 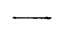 & - & - & - & - & 1.1 & - & 2.11 & 2.2 & 11.6 & 3350 & 2920 & 31.5 \\
\hline 1116 & " & 6 & $"$ & $\ldots$ & - & - & - & & & - & 1.3 & - & 2.12 & 1.9 & 10.4 & 3520 & 3000 & 34.0 \\
\hline
\end{tabular}

備考 尼-2コットレル系フライ アッシュの5ちアルフアペットで示したものはポイラ運転休止時に，数字で示したものはポイラ運転中にそれぞ れ採取したものである。化学分析は大阪窟業セメントKK研究所で行つたものである。 表中の空白部分は未試験もしくは不明の部分で克る。

(1) $88 \mu$ フルイ残分招よびブレーン比表面積の試験方法： $88 \mu$ フルイ残分肪よびブレーン方法汇よる比表面 積の測定は，ともにJIS R5201（セメントの物理試験方法）飞準じて行つた。

ブレーン方法による場合のフライ アッシュのポロシチーは，標準試料のポロシテーにできるだけ近く，乙か も供試圧縮体作製飞最も適したポロシチーを実験的に求め，その值を用いるととを原則とした。フライアッシ ユの最適ポロシチーは主として粒度分布㧍よび粒子表面の粗滑の程度などによつて相違するが，一般に 0.42 0.54 の範囲とあるようである。またその範囲内では, ポロシチーが最適值から \pm 0.04 程度変化しても, 比表面 、積の值の変化は，試験誤差の範囲々わずかに上廻る程度にすぎず，実用的には，なんらさしつかえないものと思 われる。表一3.2 は, 品質の相違する 4 種のフライ アッシュとついてポロシチーを変化させた場合の比表面積の 
試験結果の一例を示したもので, フライ アッシュの品質によつて適当なポロシチーが相違すること，適当な範 囲内ではポロシチーをある程度変化させても, 比表面積の試験值は, 実用的には, すべて同じとみなしうること などが認められる。

\begin{tabular}{|c|c|c|c|c|c|}
\hline フライ アッシュ & $\begin{array}{c}44 \mu \text { フルイ残分 } \\
(\%)\end{array}$ & ポロンチー & $\left|\begin{array}{c}\text { フンンーン比表面積 } \\
\mathrm{S}\left(\mathrm{cm}^{2} / \mathrm{g}\right)\end{array}\right|$ & 最適ポロンチー & $\frac{\text { Smax-Smin }}{\text { Smean }} \times 100$ \\
\hline No. 1116 & 11.6 & $\begin{array}{l}0.50 \\
0.48 \\
0.46 \\
0.44 \\
0.42\end{array}$ & $\begin{array}{l}3540 \\
3520 \\
3560 \\
3480 \\
3520\end{array}$ & 0.42 & 2.3 \\
\hline L & 18.2 & $\begin{array}{l}0.52 \\
0.50 \\
0.48 \\
0.46 \\
0.44\end{array}$ & $\begin{array}{l}2730 \\
2750 \\
2820 \\
2880 \\
2850\end{array}$ & 0.48 & 2.9 \\
\hline No. 79 & 10.0 & $\begin{array}{l}0.54 \\
0.52 \\
0.50 \\
0.48\end{array}$ & $\begin{array}{l}4500 \\
4570 \\
4710 \\
4490\end{array}$ & 0.52 & 4.0 \\
\hline No. 31 & 31.0 & $\begin{array}{l}0.55 \\
0.56 \\
0.54\end{array}$ & $\begin{array}{l}2900 \\
2930 \\
3030\end{array}$ & 0.56 & 4.4 \\
\hline
\end{tabular}

(2) $44 \mu$ フルイ残分の試験方法： $44 \mu$ フルイは, 米国標準試験フルイ No. 325 (フルイ ワク直径 8 in, 深さ 2 in, Tyler 社製) を用い, 試験は主として湿式ふるい分けとよつて行つた。試料は $50 \mathrm{~g}$ とし, フルイへの水 の散布には水道の蛇口（直径 $1 \mathrm{~cm}$ ）をとのまま用い，その水量を約 $13 \mathrm{l} /$ 分飞調節して約 10 分間続けた。そ の後, 残存試料をフルイとともに $110^{\circ} \mathrm{C}$ で乾燥し, 残存試料の重量を測定して $44 \mu$ フルイ残分（\%) を算出し た。散布水量を約 $13 l /$ 分飞調節したのは，水の散布によつて試料が飛散せず，かつフルイ ワクから水が越流し ない範囲で水量が最大となるように定めたためである。

な特一部の試験は, 前記の $44 \mu$ フルイを用い, JIS R5201 (セメントの物理試験方法) 飞準じて行つた。

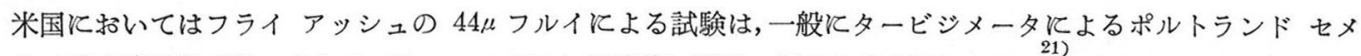

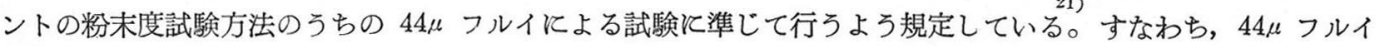
としてはフルイ ワク直径 2 in., 深さ 3 in. のむのを用い, 試料を $1 \mathrm{~g}$ として $10 \mathrm{psi}\left(0.7 \mathrm{~kg} / \mathrm{cm}^{2}\right)$ の圧力に調 節したスプレイノズルで 1 分間湿式ふるい分けを行うものとし，かつ $44 \mu$ フルイは試験回数 25 回ごとと $44 \mu$ フルイ残分が既知の標準試料で検定するよう規定している。

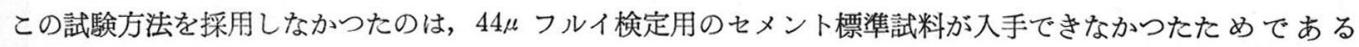
が，前記の試験方法によつても用いた $44 \mu$ フルイが十分に信頼の挌けるものであるので，所期の目的に対して はなんらさしつかえないと考えたからである。

(3) 比重計(浮八カリ)方法による粒度分布拉よび比表面積の測定方法: 通常, 粉体の粒度分布の測定には沈降方 法が最も多く利用されており, 風フルイ方法・ピペット方法・タービヂメータ方法・比重計方法怙よび天ビン方法な ど各種の方法がある。これらは粉体粒子が液体もしく は気体中を沈降する場合, 沈降速度と粒子の大きさと の間に一定の関係があることを利用したもので, 一般 にストークスの法則が用いられる。フライアッシュ の粒度分析には, 前記の各種の方法のうち, 特に比重 計方法を用いた。これは，この方法が測定装置・操作 ともに簡便であり，乙かも他の方法と同等の精度が期 待できるからである。

比重計方法によるフライ アッシュの粒度分析は JIS A1204 (土の粒度試験方法) そ準じて行つた。た だし用いた比重計は, 目盛浮バカリ 19 本組のうちの 1 本で, その測定範囲は 1.000 1.060(最小目盛 0.001)

\section{写真-3·1 比重計を用いたフライ アッシュの} 比表面積測定装置

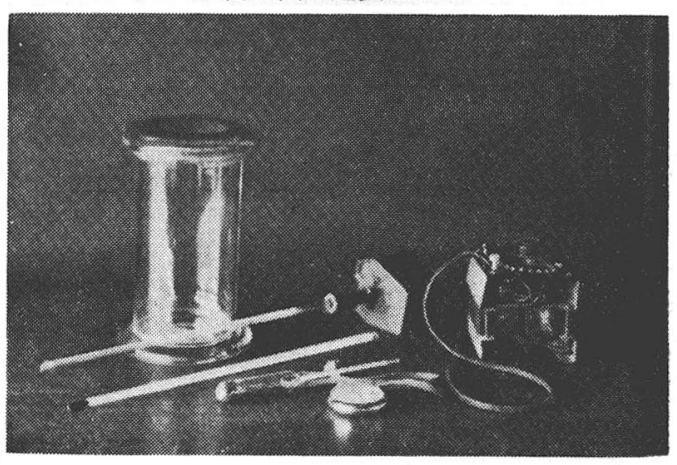


である。また懸濁液を入れる容器には,メス シリンダの代りマガラス製円筒形容器 (内径 $8.5 \mathrm{~cm}$, 深さ $17 \mathrm{~cm}$ ) を用い, 粒度分布の計算飞必要な供試䯚濁液の容積は, その重量より算出した。試料の分散装置にはタービデメ

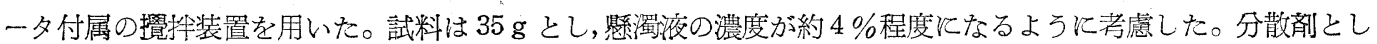
てポゾリス \#90，10\%溶液を 15 c.c. 用いた。

比重計方法によつて求めたフライ アッシュの粒度分布は, ある程度の試験誤差がさけられないので，これに 対して $44 \mu$ フルイ残分の試験值を用い，次のような補正を行つた。

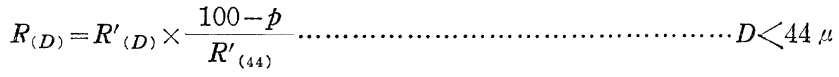

$$
\begin{aligned}
& \text { ここに } \\
& 100-R_{(D)}=\left(100-R^{\prime}{ }_{(D)}\right) \times \frac{p}{100-R_{(44)}^{\prime}} \cdots \cdots \cdots \cdots \cdots \cdots \cdots \cdots+\cdots \cdots \cdots \cdots \cdots \cdots
\end{aligned}
$$

$R_{(D)}: D \mu$ 以下の粒子の百分率 $(\%)$

$R^{\prime}(D)$ ：比重計方法より求めた粒子径加積曲線泟招ける $D \mu$ 以下の粒子の百分率（\%)

$p: 44 \mu$ フルイ残分 $(\%)$

フライアッシュの比表面積は次のようにして計算した。まづ前記の補正を行つた粒子径加積曲線より，5・10

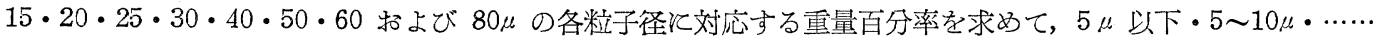
$60 \sim 80 \mu \cdot 80 \mu$ 以上の各粒子群ごとの百分率を算出し，(1)各粒子群と扮ける平均粒子径は最大径と最小径の平均 值，(2) $5 \mu$ 以下の粒子の平均径は $2.5 \mu ，(3)$ 最大粒子径は $100 \mu$ と仮定して各粒子群ごとにその表面積を計算し， それらの各粒子群沈捛ける表面積を合計してフライ アッシュの比表面積とした。

\section{表一3・3 比重計方法によるフライ アッシュの粒度分析の一例}

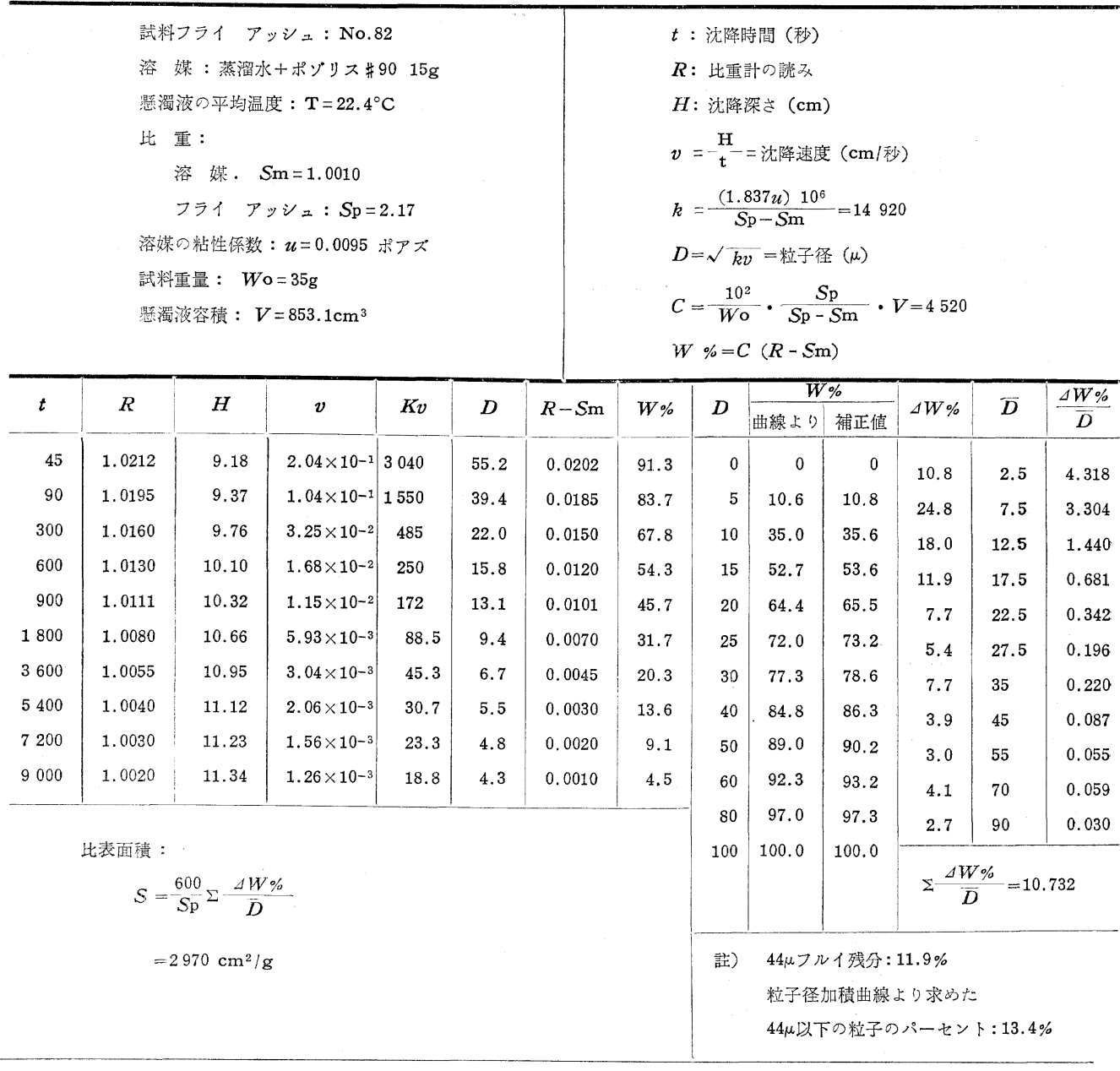




\section{表一3·4 比重計方法の再現性に関する試験結果}

\begin{tabular}{|c|c|c|c|c|}
\hline \multirow{2}{*}{ フライアッンニ } & \multicolumn{2}{|c|}{ 此表面積 $\left(\mathrm{cm}^{2} / \mathrm{g}\right)$} & \multicolumn{2}{|c|}{ 差 } \\
\hline & 第 1 回 & 第 2 回 & $\left(\mathrm{cm}^{2} / \mathrm{g}\right)$ & $(\%)$ \\
\hline$H$ & 1370 & 1410 & 40 & 2.9 \\
\hline C & 2150 & 2180 & 30 & 1.4 \\
\hline No. 82 & 2970 & 3050 & 80 & 2.7 \\
\hline No. 1116 & 3030 & 2960 & 70 & 2.3 \\
\hline
\end{tabular}

比重計方法飞よつて測定したフライ アッシュの䊀 度分布括よびとれにもとづいて比表面積を計算した結 果の一例を示せば 表一3.3 招よび 図一3.1 のと特り である。

また 表一3.4 は此重計方法によつて比表面積を求 めた場合の再現性飞関する試験結果の一例を示したも ので，比重計方法が精度も高く，十分飞信頼できる方 法であることが諗められる。

3. 吸着性試験方法 フライ アッシュの吸着性を問題とすることになつた理由は，フライ アッシュを用いた A E コンクリートの単位 A E 猎量は，フライ アッシュの吸着性によらなければ規定できないととが明らかにな つたからである。

予備的実験飞招いて，吸着される物質 (吸着質) としてメチレン ブルー $\left(\mathrm{C}_{16} \mathrm{~K}_{18} \mathrm{~N}_{3} \mathrm{~S} \mathrm{Cl} \cdot 3 \mathrm{H}_{2} \mathrm{O}\right.$, 深青色の結晶 体で水に可溶性)，醋酸怙よびドレシネートXなどについて比較検討した結果，メチレンブルーを用いるのが陚 験操作の容易さ・迅速さ招よびとの精度からいつて最むすぐれたものであることがわかつた。すなわち，有機色 素の一種であるメチレン ブルーが，単に比色によつてその吸着の程度を判定，ないしは，測定できるのに対し て，醋酸执よびドレシネート X はアルカリもしくは酸とよる中和滴定を必要とするからである。

吸着質としてメチレン ブルーを用いる場合，吸着の程度の測定方法として次の 3 つ方法が考克られる(以下 単にメチレンブルーとあるのはその水溶液を意味する)。

(a) フライ アッシュ呿よびメチレン ブルーの量を一定にして，溶液の呈色状態を比較する方法

(b) フライ アッシュの量を一定にして，メチレン ブルーを徐々に加光，着色寸前の添加量を滴定によつて 求める方法

（c）メチレン ブルーの量を一定にして，フライアッシュを徐々に加光，脱色寸前の添加量を測定する方法 これらの 3 方法を検討した結果，(a) の方法が最もすぐれていることがわからた。(b)，(c) の方法が（a）の 方法にくらべて分るのは，主として試験の操作に手数招よび時間を要する点であるが，むう一つ吸着現象の本質

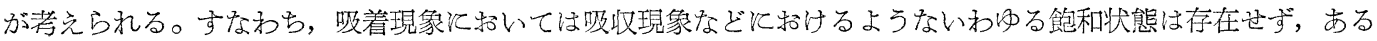
物質に対する吸着量は吸着質の濃度によつて相違し，濃度が大きくなるに従つて增加すること（図一3・2)招よび 吸着量がほぼ一定值に達しない範囲の濃度に和いても吸着質の一部は吸着されず残つて平衡状態を保つことな ぞそより，着色もしくは脱色前後法ける溶液の色調の変化がきわめて鈍いため（中和滴定の際の指示薬による 変色飞比して) 十分な精度が期待できないからである。

(a)の方式による試験方法は次のようにして行つた。まつ試験管にメチレン ブルー水溶液(濃度: $35 \mathrm{mg} / l) 25$ c.c. を入れ，ついで試料フライ アッシュ $1 \mathrm{~g}$ を加兄て約 1 分間手で十分飞振とうしたのち，乙の䀣濁液を濾過

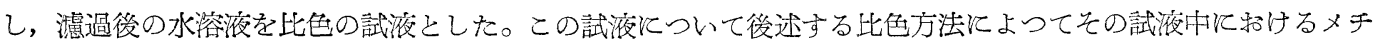
レンブルーの残存濃度を測定した。フライ アッシュ $1 \mathrm{~g}$ 当りの吸着量は, 原水溶液のメチレンブルー濃度执よ び試液中のメチレン ブルー残存濃度から算出した。すなわち

$$
d=\frac{1}{40}\left(N-N^{\prime}\right)
$$

ここに $d:$ フライ アッシュ $1 \mathrm{~g}$ 当りのメチレンブルー吸着量 $(\mathrm{mg})$

$N$ : 原水溶液メチレン ブルー濃度 $(\mathrm{mg} / l)$

$N^{\prime}:$ 滤過試液メチレンブルー濃度 $(\mathrm{mg} / \mathrm{l})$

比色方法によるメチレン ブルー水溶液の濃度測定には，次の 2 つの方法を用いた。 
（a）濃度既知のメチレン ブルー 水溶液を何種類かつくつてお いてそれを標準液とし, 試液の色調がどの標準液に等しいかを見る ことによつて試液の濃度を求める。

(b) 濃度甈知のメチレン ブルー水溶液を 1 種類つくつて沶い てそれを標準液とし, 試液の液層の厚さを加減して標準液と色調が 等しくなる点を求め, ベールの法則によつて試液の濃度を求める。

(a) 亿対しては, 光電管比色計飞よる方法と視察による方法の 2 方法を用い，（b）飞対してはいわゆる比色計が入手できなかつたの で視察による方法のみを用いて比較した。その結果, 視察による方 法によつて十分な精度をうるととが明らかそなつた。

4. 所要水量比試験方法 フライ アッシュの品質判定の一方法

図一3.2 フライ アッシュの吸 着等温度曲線の一例

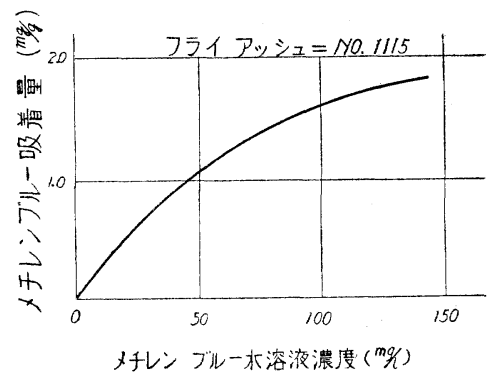
として，モルタルルよるいわゆる所要水量比試験が行われている。

本試験飞招いては JIS R 5201 (セメントの物理試験方法) そ準じてフローが 200 215mm そなるような基準 配合の水量を定め, フライ アッシュの所要水量比は基準配合のフローと等しくなるような水量を求めて次式に より算出した。

$$
\text { 所要水量比 }(\%)=\frac{\text { 試験配合の水量 }}{\text { 基準配合の水量 }} \times 100
$$

な括，試験はモルタルの配合・眇の種類・フライ アッシュの種類などを変えて行い，さらに豊浦標準砂を用 いた場合の所要水量比の検討並びそ所要水量比と粉末度敊よび強熱減量との関係などを調べた。

5. ポゾラン活性試験方法

(1) 石灰ポゾラン砂モルタル強度試験方法：フライ アッシュの石灰モルタル試験を行つたのは, フライアッ シュのポゾラン活性をできるだけ早急に判定するためであるが, 本試験では Bureau of Reclamation Specification No.1904 “Calcined Reactive Silicious Material for Use in Concrete” (石灰との反応性試験方法) そ準じて行つた。この試験は, 重量配合比 $1: 2: 9$ の石灰ポゾラン砂モルタル供武体 $\left(5 \times 10 \mathrm{~cm}\right.$ 円柱)を $54^{\circ} \mathrm{C}$ 飞保つた密閉容器内で一週間促進養生を行つたのち, 圧縮強度試験を行い, その強度が $42 \mathrm{~kg} / \mathrm{cm}^{2}$ 以上となるこ とを要求するものである。本試験では石灰は JIS 規格の特級品を用い，砂は主として相馬砂を用いた。な怙一 部の試験では Ottawa 標準砂も用いた。

(2) セメント・フライ アッシュ砂モルタル強度試験方法:セメントモルタルの圧縮強度試験は，アサノマス コンセメントを用い，基準配合招よび試験配合の両者について行つた。供試体の製造拉よび圧縮強度試験は， 次の事項を除きすべて JIS R 5201 (セメントの物理試験方法)によつた。

a. 配合試験江用いた配合は次のと衫りである。

$$
\text { セメント (g) }
$$

フライアッシュ $(\mathrm{g})$

豊浦標準砂 $(\mathrm{g})$

水
基準配合

0

1040

200〜215 のフローを

うるの江必要な水量
試験配合

364

156

1040

同左

b. 供試体の養生供試体は，成形後 24 時間 $20 \pm 3^{\circ} \mathrm{C}$ 亿保つた湿気箱に入れて保存したのち脱ワクし，た

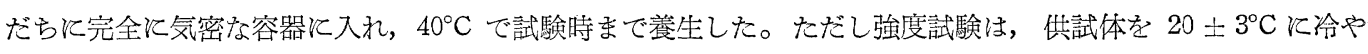
してから行つた。

c. 試験材令 圧縮強度試験は材令 28 日で行つた。

d. 圧縮強度比圧繀強度の試験值は供試体 6 個の平均值をとり，圧縮強度比は次式で計算した。

$$
\text { 王繀強度比 }(\%)=\frac{\text { 試験配合の圧縮強度 }}{\text { 基準配合の圧縮強度 }} \times 100
$$

\section{[3]試験の結果}

1. 化学成分 表一3.1 飞示した尼ケ崎フライアッシェ 26 種について化学成分の範囲敊よびその平均值を示

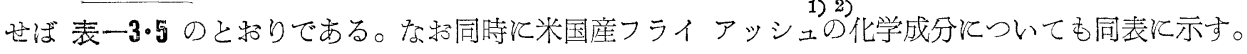

表一3.5 より次のととが認められる。

（1）尼ケ崎フライアッシュの主成分はシリカ・アルミナ・酸化鉄などで，そのうちシリカが最む多く約 $56 \%$ 
表一3.5 フライアッシュの化学成分

\begin{tabular}{l} 
フライ アッシニ \\
\hline
\end{tabular}

*18種のフライ アッシュの平均值である。

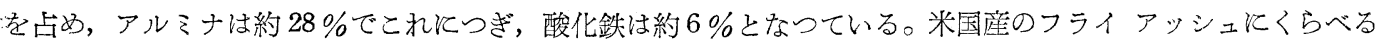
とシリカがやや多く, 酸化鉄がやや少ない。

（2）採取条件による尼ケ崎フライアッシュの化学成分の変動はきわめて少なく，実用的にはすへて同一とみ なしうる。これは，使用石炭の品質がボイラの性能の方から相当厳密䙺定されていることによるものであ る。

（3）尼ケ崎フライ アッシュの強熱減量は $0.7 \sim 4.3 \%$ 範囲にあるが，これは米国産のフライ アッシュにく らべてきわめて少ない值である。一般にフライ アッシュの強熱減量が少ないほどボゾラン活性もすぐれている ようであるが，強熱減量が約 $3 \%$ 以下では強熱減量とそのポゾラン活性との間には特に関係仕認められない。

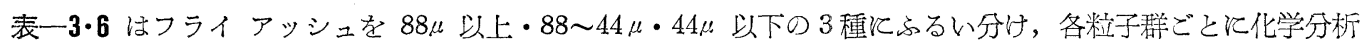
を行つた結果の一例である。この表より, 強熱減量を除けげフライ アッシュの化学成分は, その椟子の大きさ そよつてほとんど相違しないことが認められる。屯た強熱減量は粗粒子群の方が多く, 特に $88 \mu$ 以上の粒子群

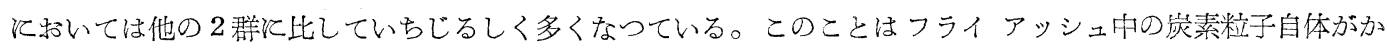
なり大きいととを示すものである。

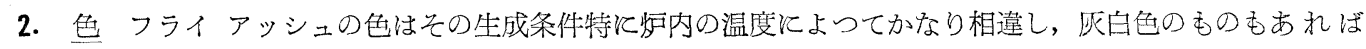
やや黒色を和びたものもある。一般的にいつて桠内の温度が高いときは灰白色，低いときは黒色のフライアッ シュを生ずるが，その色が異なる場合にも化学成分・物理的性質などがほとんど同じであることが多い。強熱減 量の多いフライアッシュ，すなわち含有炭素の多いフライアッシュほど色が黒いように想像されるが，実際は 必ずしもそうではない。むしろ全く逆な場合もある。従つてフライ アッシュの色とそのポゾラン活性との間に は関係が認められず，その意味では，フライアッシュの色は，その品質を判定するめやすとはならない。

色の黒いフライ アッシュを用いればコンクリートの表面が黒くなり構造物の美観を損ずるが硬化後時日を経 たコンクリートはその表面に炭酸石灰の白い斑点を生し，これが色彩的に一種の保護膜の役目を果してくれるの

表一3.6 粒子群别のフライ アッシュの化学成分

\begin{tabular}{|c|c|c|c|c|c|c|c|c|c|}
\hline フライ & アッシュ & & & 化 & 学 & 成 & $(\%)$ & & \\
\hline 名 称 & 粒子群 & 强熱減量 & 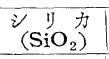 & $\begin{array}{l}\text { アルミナ } \\
\left(\mathrm{Al}_{2} \mathrm{O}_{3}\right)\end{array}$ & 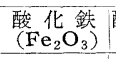 & $\begin{array}{c}\text { 酸化カルシウム } \\
(\mathrm{CaO})\end{array}$ & $\begin{array}{l}\text { マイネンア } \\
\text { (MgO) }\end{array}$ & \begin{tabular}{|c} 
無水硫酸 \\
$\left(\mathrm{SO}_{3}\right)$
\end{tabular} & 崖 $(\mathrm{C})^{\text {素 }}$ \\
\hline \multirow{3}{*}{ G } & $88 \mu$ 以上 & 10.2 & $\begin{array}{c}51.4 \\
(57.3)\end{array}$ & $\begin{array}{c}24.8 \\
(27.6)\end{array}$ & $\begin{array}{c}4.5 \\
(5.0)\end{array}$ & $\begin{array}{c}5.3 \\
(5.9)\end{array}$ & $\begin{array}{c}1.4 \\
(1.8)\end{array}$ & $\begin{array}{l}1.1 \\
(1.3)\end{array}$ & 8.1 \\
\hline & $88 \mu \sim 44 \mu$ & 3.6 & $\begin{array}{c}56.5 \\
(58.6)\end{array}$ & $\begin{array}{c}26.3 \\
(27.3)\end{array}$ & $\begin{array}{c}5.4 \\
(5.6)\end{array}$ & $\begin{array}{c}4.7 \\
(4.9)\end{array}$ & $\begin{array}{l}1.4 \\
(1.5)\end{array}$ & $\begin{array}{c}0.6 \\
(0.6)\end{array}$ & 2.5 \\
\hline & $44 \mu$ 以下 & 2.0 & $\begin{array}{c}56.4 \\
(57.6)\end{array}$ & $\begin{array}{c}27.4 \\
(28.0)\end{array}$ & $\begin{array}{c}7.4 \\
(7.6)\end{array}$ & $\begin{array}{l}3.6 \\
(3.7)\end{array}$ & $\begin{array}{l}1.7 \\
(1.7)\end{array}$ & $\begin{array}{c}0.2 \\
(0.2)\end{array}$ & 1.3 \\
\hline \multirow{3}{*}{$\mathrm{H}$} & $88 \mu$ 以上 & 4.9 & $\begin{array}{c}58.3 \\
(61.3)\end{array}$ & $\begin{array}{c}25.9 \\
(27.2)\end{array}$ & $\begin{array}{c}4.0 \\
(4.2)\end{array}$ & $\begin{array}{c}3.9 \\
(4.1)\end{array}$ & $\begin{array}{c}1.5 \\
(1.6)\end{array}$ & $\operatorname{tr}$ & 3.2 \\
\hline & $88 \mu \sim 44 \mu$ & 2.0 & $\begin{array}{c}58.7 \\
(60.0)\end{array}$ & $\begin{array}{c}24.6 \\
(25.1)\end{array}$ & $\begin{array}{c}(4.2) \\
6.7 \\
(6.8)\end{array}$ & $\begin{array}{c}4.7 \\
(4.8)\end{array}$ & $\begin{array}{l}1.6 \\
(1.6)\end{array}$ & $\begin{array}{c}0.2 \\
(0.2)\end{array}$ & 1.1 \\
\hline & $44 \mu$ 以下 & 1.5 & $\begin{array}{c}57.1 \\
(58.0)\end{array}$ & $\begin{array}{c}27.0 \\
(27.4)\end{array}$ & $\begin{array}{l}7.0 \\
(7.7)\end{array}$ & $\begin{array}{c}3.6 \\
(3.7)\end{array}$ & $\begin{array}{c}1.9 \\
(1.9)\end{array}$ & $\operatorname{tr}$ & 0.8 \\
\hline \multirow{3}{*}{723} & $88 \mu$ 以上 & 4.2 & $\begin{array}{c}58.7 \\
(61.4)\end{array}$ & $\begin{array}{l}27.5 \\
(28.7)\end{array}$ & $\begin{array}{c}2.2 \\
(2.3)\end{array}$ & $\begin{array}{l}4.2 \\
(4.4)\end{array}$ & $\begin{array}{l}1.2 \\
(1.3)\end{array}$ & $\begin{array}{c}0.2 \\
(0.2)\end{array}$ & 3.1 \\
\hline & $88 \mu \sim 44 \mu$ & 2.6 & $\begin{array}{c}58.3 \\
(60.0)\end{array}$ & $\begin{array}{c}27.8 \\
(28.6)\end{array}$ & $\begin{array}{c}3.6 \\
(3.7)\end{array}$ & $\begin{array}{c}4.4 \\
(4.5)\end{array}$ & $\begin{array}{l}1.3 \\
(1.3)\end{array}$ & $\begin{array}{c}0.2 \\
(0.2)\end{array}$ & 1.4 \\
\hline & $44 \mu$ 以下 & 1.2 & $\begin{array}{c}55.6 \\
(56.3)\end{array}$ & $\begin{array}{l}29.6 \\
(30.0)\end{array}$ & $\begin{array}{c}5.8 \\
(5.9)\end{array}$ & $\begin{array}{c}4.5 \\
(4.6)\end{array}$ & $\begin{array}{c}1.7 \\
(1.7)\end{array}$ & $\begin{array}{c}0.4 \\
(0.4)\end{array}$ & 0.5 \\
\hline 備 & 考 & \multicolumn{8}{|c|}{$\begin{array}{l}\text { カッコ内の数字は強熱減量を除いた部分に対する百分率を示す。 } \\
\text { 化学分析は大阪窵業セメントKK 研究所で行つたものである。 }\end{array}$} \\
\hline
\end{tabular}


で，黒いフライ アッシュを用いたコンクリートの色も時日の経過ととむに白くなり，実際上問題でなくなる。

3. 比重 表一3.1 亿示したようと, 尼ケ崎フライ アッシュの比重は 2.0 2.2 の範囲にあり, 平均して 2.1 前後である。この值は米国産フライ アッシュの比重が約 2.4 前後であるのにくらべてやや小さい。これは主と 乙て両者の化学成分の差, すなわち, 尼ケ崎フライ アッシュが米国産のフライ アッシュに比してシリカがやや 多く，酸化鉄が少ないととによるものと思われる。

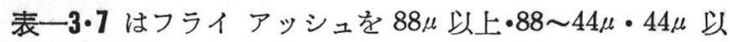
下の 3 種とらるい分け，各粒子群ごとに比重を測定した結果

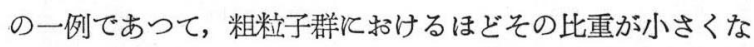
つている。このことはフライ アッシュの化学成分がほぼ同 じ場合には, フライ アッシュの粉末度が粗いものほど比重 が小さいこと，逆にいえば比重の小さなものほど粉末度が粗 いととを示すものと思われる。これは 表一3・1 と示したフラ イアッシュのうち, 粉末度が特に粗い $\mathrm{G} ・ \mathrm{H} ・ \mathrm{I} ・ \mathrm{~J}$ などの 比重が約 2.0 以下となっていて, 他のフライ アッシュより も一段小さな值を示しているととからも裹づけるととができ

表-3.7 各粒子群别のフライ アッシュの比重

\begin{tabular}{|c|c|c|c|c|}
\hline \multirow{2}{*}{$\begin{array}{l}\text { フライ } \\
\text { アッシニ }\end{array}$} & \multicolumn{2}{|r|}{ 比 } & \multicolumn{2}{|c|}{ 重 } \\
\hline & 全 粒子 & $88 \mu$ 以上 & $88 \sim 44 \mu$ & $44 \mu$ 以下 \\
\hline$P$ & 2.16 & 1.87 & 1.96 & 2.21 \\
\hline 723 & 2.09 & 1.82 & 1.98 & 2.14 \\
\hline 1116 & 2.12 & 1.78 & 1.96 & 2.13 \\
\hline $\mathbf{S}_{1}$ & 1.96 & $-^{*}$ & 1.91 & 2.08 \\
\hline 備 考 & $\begin{array}{l}{ }^{*} \text { 印の\& } \\
\text { 分多く液 } \\
\text { 外した。 }\end{array}$ & 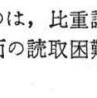 & $\begin{array}{l}\text { 免におい } \\
\text { ごあつた }\end{array}$ & $\begin{array}{l}\text { 遊粒子部 } \\
\text { れを除 }\end{array}$ \\
\hline
\end{tabular}

る。概して, 比重が 2.0 以下であるようなフライ アッシュは粉末度も粗く, 従つてそのポゾラン活性もあまり 期待できないととが多い。粗粒子群のフライ アッシュほど,その比重が小さいのは，粒子が粗くなるほど粒子自 体の空吵率が増加することによるものと思われる。こ のととはフライ アッシュを粉砕した場合に比重が増 加することによつても明らかである。

4. 単位容積重量 表一3.8 はフライ アッシュの単 位容積重量の一例を示したものである。フライアッ シュの単位容積重量は, セメントと同じく比重・粉末 度・粒子表面の粗滑の程度・測定方法などとよつて相 違するが，一般飞良質の尼ケ崎フライ アッシュにつ いていえば，軽く詰めた場合には約 $900 \mathrm{~kg} / \mathrm{m}^{3}$, 十分 摇りこえで詰めた場合には約 $1000 \mathrm{~kg} / \mathrm{m}^{3}$ である。

5. 粒子形状 フライアッシュは,一般と球状をな てた杼子が多数含まれている。これは前述のようにそ の成生の過程からむ容易に考光られることであつて,

写真一3・2 3.8 は, フライ アッシュの顕微鏡写真を 7 種のフライ アッシュについて示したものである。 これによつて明らかなようにフライアッシュの粉末 度のいかんにかかわらずその大部分が球状をなしてい るととが認められる。

写真一3・2 フライ アッシュの顕微鏡写真 種類：コットレル系フライアッシュ $\mathrm{A}$ ブレーン比表面積: $3680 \mathrm{~cm}^{2} / \mathrm{g}$

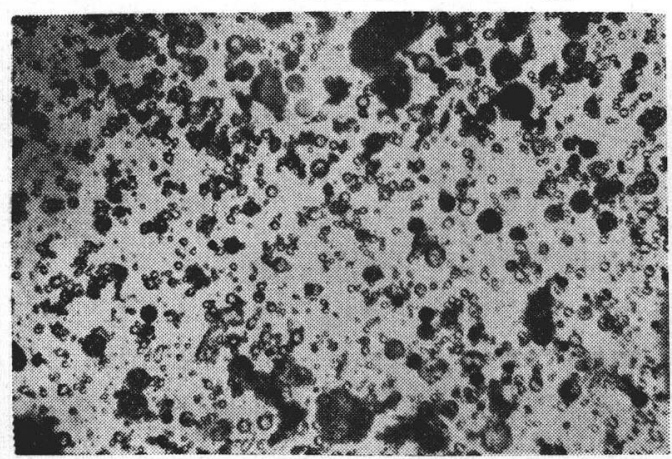

表一3.8 フライ アッシュの単位容皘重量

\begin{tabular}{|c|c|c|c|c|c|}
\hline \multirow{2}{*}{$\begin{array}{l}\text { フライ } \\
\text { アッシュ }\end{array}$} & \multirow{2}{*}{$\begin{array}{c}88 \mu>ル 1 \\
\text { 残分 } \\
(\%)\end{array}$} & \multicolumn{2}{|c|}{$\begin{array}{l}\text { 単位容積重量 } \\
\left(\mathrm{kg} / \mathrm{m}^{3}\right)\end{array}$} & \multicolumn{2}{|c|}{ 空隙率 (\%) } \\
\hline & & $\begin{array}{l}\text { } る く つ ~ \\
\text { めた場合 }\end{array}$ & $\begin{array}{l}\text { 士分に心に } \\
\text { こんた場合 }\end{array}$ & $\begin{array}{l}\text { } る く つ ~ \\
\text { めた場合 }\end{array}$ & $\begin{array}{l}\text { 十分に㑋り } \\
\text { こんた場合 }\end{array}$ \\
\hline C & 5.2 & 820 & 960 & 61 & 54 \\
\hline L & 4.3 & 840 & 980 & 60 & 53 \\
\hline $\mathbf{M}$ & 3.3 & 810 & 940 & 61 & 55 \\
\hline $\mathrm{N}$ & 2.4 & 980 & 1040 & 55 & 50 \\
\hline $\mathrm{O}$ & 3.0 & 810 & 920 & 62 & 57 \\
\hline $\mathbf{P}$ & 2.8 & 880 & 990 & 59 & 54 \\
\hline 723 & 2.5 & 900 & 950 & 57 & 55 \\
\hline 1116 & 1.9 & 940 & 1050 & 56 & 50 \\
\hline $\mathrm{S}_{1}$ & 30.0 & 570 & 690 & 71 & 65 \\
\hline $\mathrm{S}_{2}$ & 9.2 & 780 & 900 & 63 & 57 \\
\hline $\mathrm{S}_{3}$ & 3.0 & 790 & 860 & 65 & 61 \\
\hline 330 & 8.8 & 860 & 1020 & 57 & 49 \\
\hline 備 考 & $\begin{array}{l}\text { 用いた容 } \\
\text { である。 }\end{array}$ & 器は内径 25 & $\mathrm{~cm}$, 高さ & $8 \mathrm{~cm}$ の鉄謷 & 円筒容器 \\
\hline
\end{tabular}

写真一3・3 フライ アッシュの顕微鏡写真

種類：コットレル系フライアッシュB ブレーン比表面積: $3270 \mathrm{~cm}^{2} / \mathrm{g}$

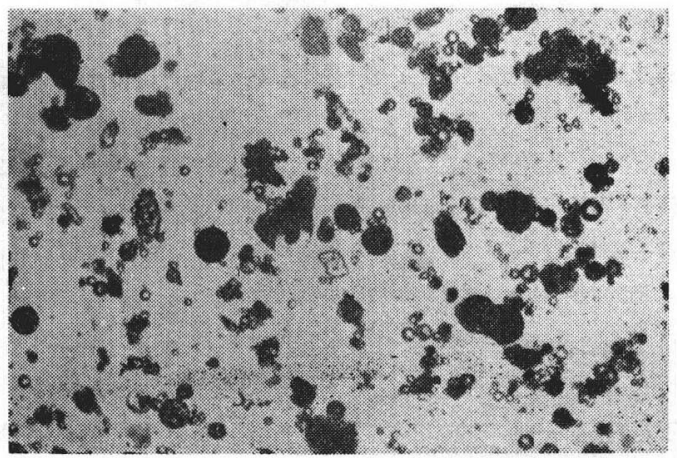


写真一3.4 フライ アッシュの顕微鏡写真 種類: コットレル系フライアッシュD ブレーン比表面積: $2660 \mathrm{~cm}^{2} / \mathrm{g}$

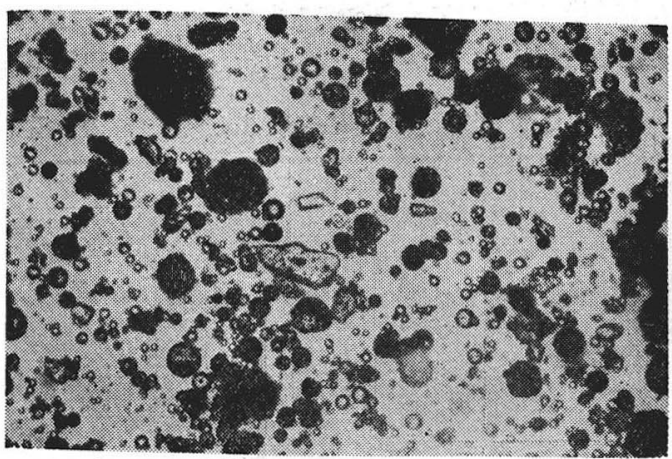

写真一 $3 \cdot 5$ フライ アッシュの顕微镜写真 種類:コットレル系フライアッシュ $\mathrm{E}$ ブレーン比表面積：3 $110 \mathrm{~cm}^{2} / \mathrm{g}$

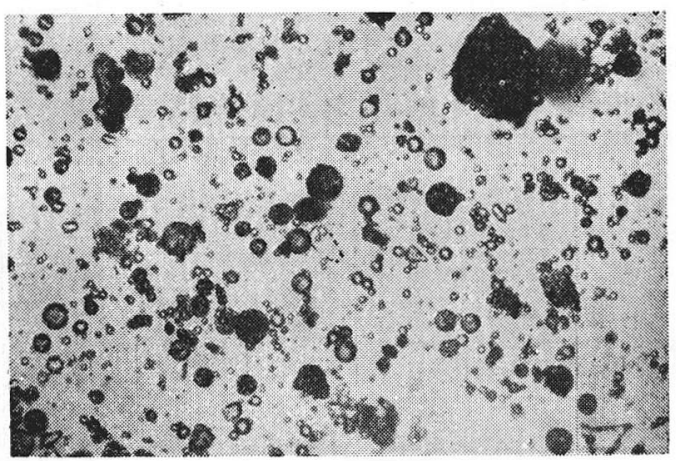

写真一3.6 フライ アッシュの顕微鏡写真 種類:コットレル系フライアッシュ $\mathrm{F}$ ブレーン比表面積: $2750 \mathrm{~cm}^{2} / \mathrm{g}$

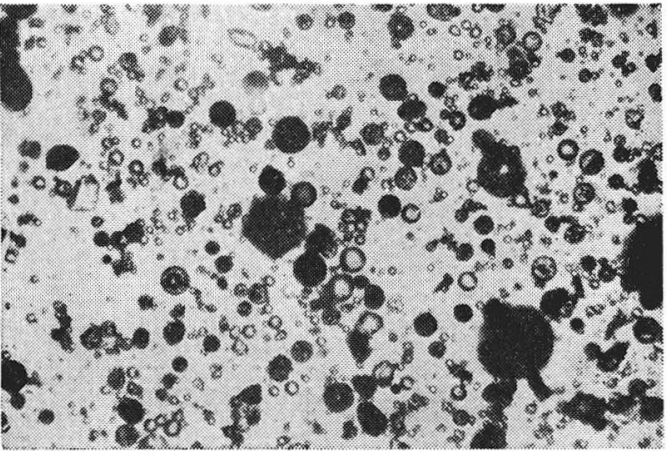

またフライ アッシュ B・M・No. 1115 そついて, 風 らるい方法により限界粒子徍 $40 \cdot 30 \cdot 20 \cdot 15 \mu$ で, 風心 るいし, 各粒子群ごとに粒子 100 個の形状を観察し, こ れを円形部分と多角形部分とに分類して表わした結果は 表一3.9 のと赫りであり，大体の傾向として細粗いづれ の粒子群に扮いても球状粒子が支配的であること，招よびとの傾向は細粒子群飞捛けるほど大きくなるととがわ かる。これは前述したように粗䊀子群に扔けるほど炭素含有量が増加することによるものと考劣られる。

このようにフライアッシュは，その粒子の大部分が球状をなしているととによつて，同じ粉体の中でも粉砕 工程を経たセメントや他のポゾランにはみられない特性をもつている、
写真一3・7 フライ アッシュの顕微鏡写真 種類:コットレル系フライ アッシュ G ブレーン比表面積: $2280 \mathrm{~cm}^{2} / \mathrm{g}$

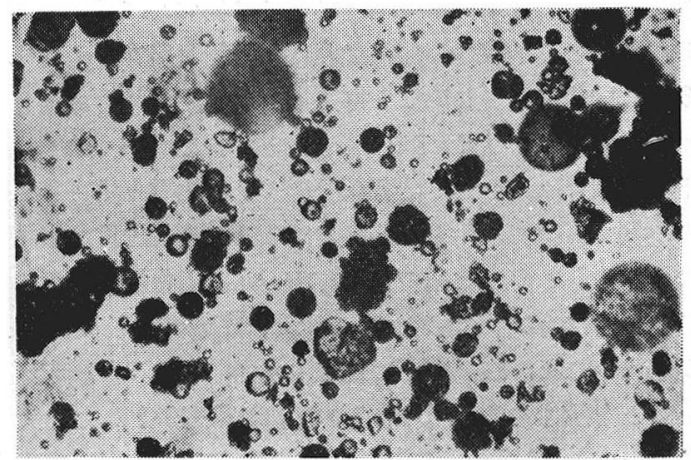

写真一3.8 フライ アッシュの顕微鏡写真 種類:コットレル系フライアッシュ $\mathrm{J}$ ブレーン比表面積：1800 $\mathrm{cm}^{2} / \mathrm{g}$

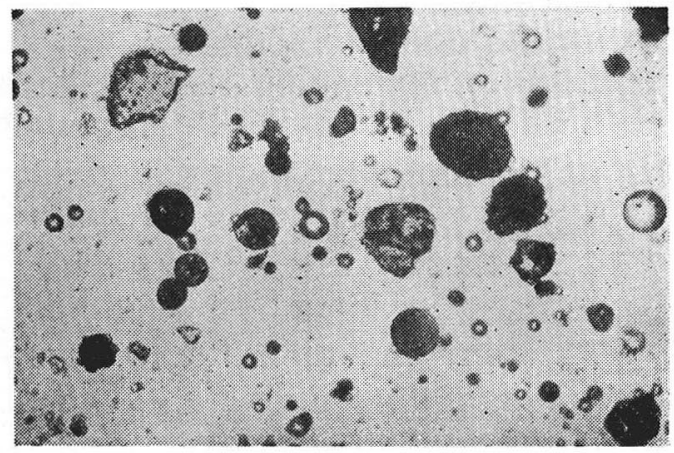

表一3・9 フライ アッシュの風フルイ 試験結果と粒子形状

\begin{tabular}{|c|c|c|c|c|}
\hline \multirow{2}{*}{$\begin{array}{l}\text { フライ } \\
\text { アッシ }\end{array}$} & \multirow{2}{*}{ 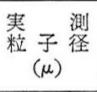 } & \multirow{2}{*}{ 残 $(\%)^{\text {分 }}$} & \multicolumn{2}{|c|}{$\begin{array}{c}\text { 限界粒子形状 } \\
(100 \text { 二中) }\end{array}$} \\
\hline & & & 円形(コ) & 多角形 ( コ) \\
\hline \multirow{4}{*}{ B } & 14.6 & 65.6 & 70 & 30 \\
\hline & 20.0 & 53.0 & 79 & 21 \\
\hline & 30.3 & 36.2 & 50 & 50 \\
\hline & 43.2 & 21.2 & 52 & 48 \\
\hline \multirow{4}{*}{$\mathbf{M}$} & 14.6 & 67.6 & 78 & 22 \\
\hline & 19.7 & 59.6 & 72 & 28 \\
\hline & 31.8 & 39.6 & 65 & 35 \\
\hline & 45.4 & 22.4 & 60 & 40 \\
\hline \multirow{4}{*}{ No.1115 } & 14.1 & 58.4 & 89 & 11 \\
\hline & 18.1 & 47.6 & 80 & 20 \\
\hline & 31.6 & 29.5 & 61 & 39 \\
\hline & 43.0 & 16.6 & 65 & 35 \\
\hline
\end{tabular}


6. 粉末度 表一3.1 そ示した数值にもとづいて, 粉末度の範团拉よび平均值を, ボイラ運転休止時に採取し たものと，ボイラ運転中に採取したものとの 2 群と分けて示せば 表一3.10 のと招りである。

表一3.10 試験研究の対象とした尼ケ崎フライ アッシュの粉末度

\begin{tabular}{|c|c|c|c|c|c|}
\hline \multicolumn{2}{|c|}{ フテイアッシニ } & $\begin{array}{c}88 \mu \text { フルイ残分 } \\
(\%)\end{array}$ & $\begin{array}{c}44 \mu \text { フイル残分 } \\
(\%)\end{array}$ & $\begin{array}{c}\text { フレーン比表面積 } \\
\left(\mathrm{cm}^{2} / \mathrm{g}\right)\end{array}$ & $\begin{array}{c}\text { 比重計方法比表面積 } \\
\left(\mathrm{cm}^{2} / \mathrm{g}\right)\end{array}$ \\
\hline \multirow{2}{*}{$\begin{array}{l}\text { ボイラ運転休止時に採取 } \\
\text { したもの18種 }\end{array}$} & 範 团 & $1.8 \sim 22.6$ & $12.0 \sim 57.6$ & $1800 \sim 3680$ & $820 \sim 2840$ \\
\hline & 平均値 & 6.8 & 25.6 & 2920 & 1880 \\
\hline \multirow{2}{*}{$\begin{array}{l}\text { ボイラ運転中に採取した } \\
\text { もの18種 }\end{array}$} & 範 团 & $1.1 \sim 3.0$ & $8.7 \sim 18.5$ & $3350 \sim 4730$ & $2780 \sim 3340$ \\
\hline & 平均値 & 2.2 & 12.9 & 4090 & 3030 \\
\hline
\end{tabular}

表一3・1 捛よび 表一3・10 から次のととが認められる。

（1）試料とした尼ケ崎フライ アッシュのうち，ボイラ運転休止時に採取したフライ アッシュの粉末度は $88 \mu$ フルイ残分で 1.8 17.3\%，ブレーン比表面積で $2000 \sim 3620 \mathrm{~cm}^{2} / \mathrm{g}$ の範囲汇あつてかなり大幅に変化し

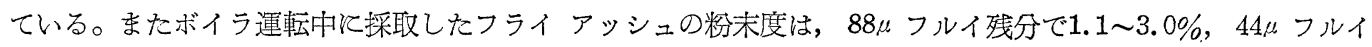
残分で 8.7 18.5\%，ブレーン比表面積で $3350 \sim 4730 \mathrm{~cm}^{2} / \mathrm{g}$ となつていて，国産フライ アッシュとしては， 良質の部類嘱することが諗められる。

図一3・3 フライ アッシュの粒度分布をヒストグ ラムで示した例
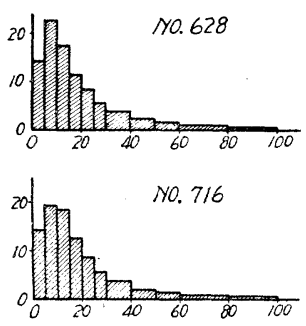

No. 721

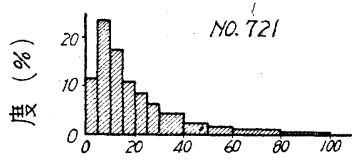

蜜
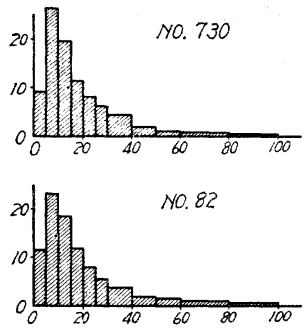

粒子 径 $(\mu)$.

(2) 図一3・3 はボイラ運転中に採取したフライ アッシュ10種に ついて, 比重計方法により求めた粒度分布をヒストグラムで示し

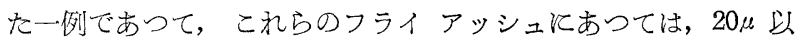
下の粒子が全体の約 $65 \%$ を占めて拈り，特に $5 \sim 10 \mu$ の範囲の 粒子が最も多く，季た $5 \mu$ 以下の粒子も相当量含杂れていること が認められる。

図一3.4 は参考のために, 市販セメント3 種について比重計方 法淿より求めた粒度分布をヒストグラムで示した一例であるが， これらのセメントと前記のフライ アッシュの粒度分布を比較す
図一3.4 セxントの粒度分布をヒス トグラムで示したー例
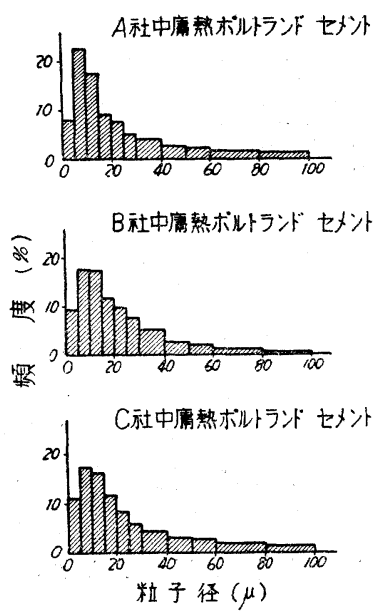

図一3.5 サイクロン系フライ アッシュ

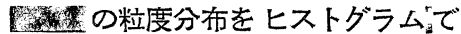
示した一例

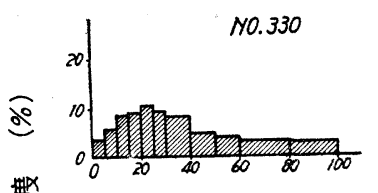

幽 $S_{i}$ 棵

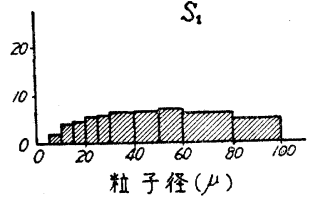


ればほぼ似かよつた傾向を示して和り，その粒度分布面からみた場合，市販セメントと良質の尼ケ崎フライア ッシュの粉末度がほぼ同程度であることが認められる。

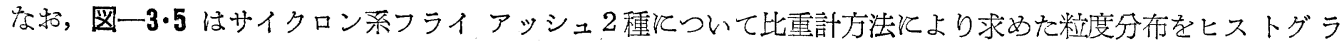
ムで示した一例である。

\section{図一3·6 フライ アッシュのブレーン 比表面積と比重計方法による 比表面皘との関係}

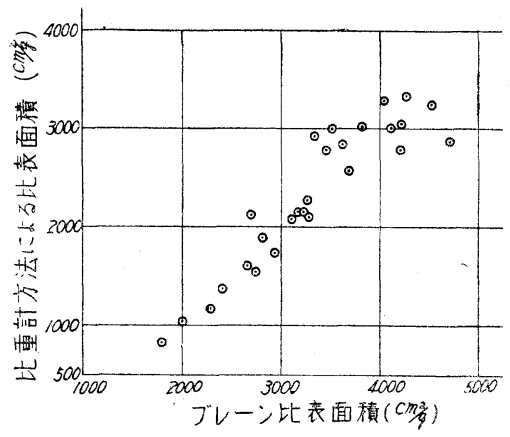

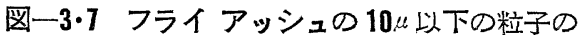
百分率とブレーン比表面積との関係

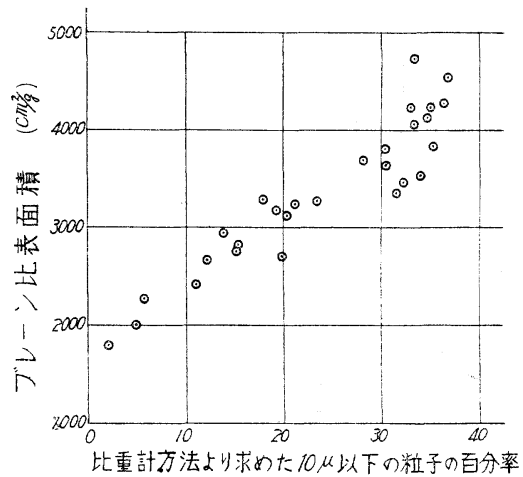

（3）図-3.6 は 表一3.1 の数值にもとづいて，フライアッシュのブレーン比表面積と比重計方法による比表 面積との関係を示したあのであつて，両者の間にはその絶対值にある程度の差があるが(ブレーン比表面積が比 重計方法にくらべて $1000 \mathrm{~cm}^{2} / \mathrm{g}$ 程度大きい), ほぼ直線的関係攵ることが認められる。また，図一3.7 は比重 計方法により求めたフライ アッシュの $10 \mu$ 以下の粒子の百分率とブレーン比表面積との関係を示したもので, 図一3.6 と同様に両者の間にはほぼ直線的関係が認められる。とれらの相関性はブレーン比表面積がフライ アッ シュの粉末度を表わす尺度として，その測定方法の簡便さと相まつて，有効な方法であることを示すものと思わ れる。

（4）図一-3.8 は，表-3.1 の数值にもとづいてフライ アッシュの $44 \mu フ ル イ$ 残分と比重計方法による比表面 積との関係を示したあのである。兩者の間には，ほぼ直線的関係が認められるが，この直線的関係のうちに包含 されないフライアッシュも少なくない。このととは, コットレル系フライ アッシュの粒度分布状態にはある規 則性が認められるが, 笅密な意味では, ボイラ特性・集鹿器特性招よび負荷状態などによつて, その規則性にあ る程度の幅があること, 特よび, フライ アッシュの粒子径加積曲線からも認められるように, 精子径 $44 \mu$ 程度 では同曲線のごくスソの方を押兄ているに過ぎないととなどに よるものと思われる。しかし，これらのととを加味しても，な

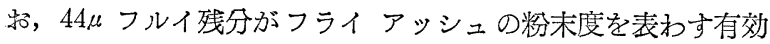
な方法であることはいうまでもない。

(5) 図一-3.9 は，表-3.1 の数值ともとづいて,フライ アッ シュの $88 \mu$ フルイ残分と $44 \mu$ フルイ残分との関係を示したもの

\section{図一3.8 フライ アッシュの $44 \mu$ フルイ残分と 比重計方法による比表面積との関係}

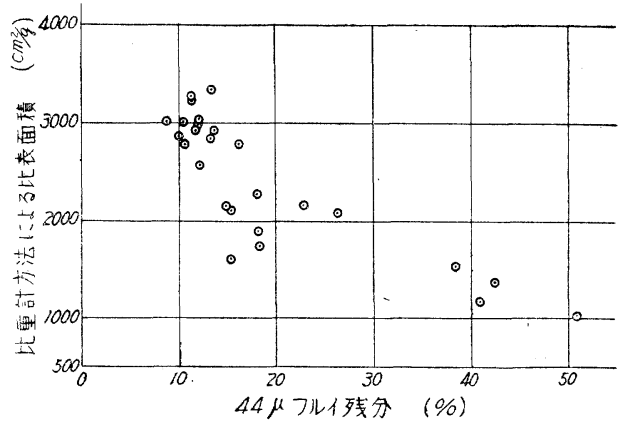

図一3.9 フライ アッシュの $88 \mu$ フルイ残 分と $44 \mu$ フル残分との関係

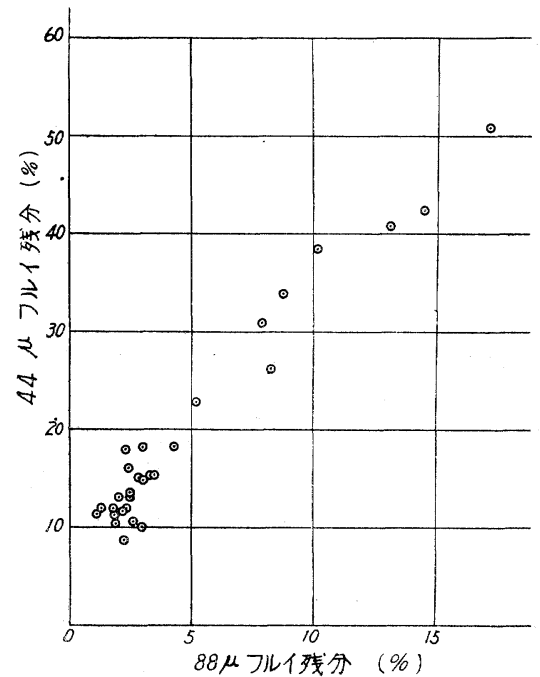


であつて,両者の間にはほぼ直線的関係が認められる。このことは フライ アッシュの粉末度を測定する場合, フルイルよる試験と

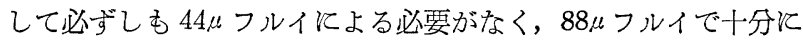
めやすをうることを示すものと思われる。な拉図一 $3 \cdot 9$ から判断 すると,フライ アッシュの $88 \mu$ フルイ残分が $5 \%$ のあのは $44 \mu$ フルイ残分では約 $20 \%$ 程度に相当するようである。

(6) 図-3.10 は，表-3.1 の数值飞むとづいてフライ アッシ ニのブレーン比表面積と強熱減量との関係を示したものであるが 両者の間には別に関係が認められない。このととは，あるフライ アッシュの強熱減量を粒子径別とみた場合, 強熱減量がとの䊀子 徍に比例して増加する傾向にあること，すなわら粗粒子のあのほ ど強熱減量が多いということと一見矛盾しているよう教兄られ るが，後者の傾向はあくまでああるフライアッシュ内に敊ける

図一3・10 フライ アッシュの強熱減量亡 粉末度との関係

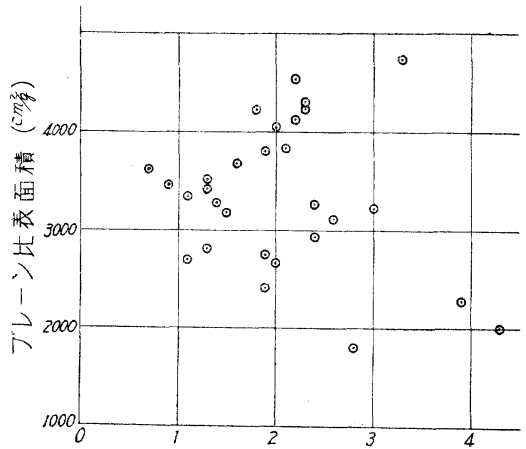

強熱減量(\%) 相対的な性質であつて，個々のフライアッシュについてその粉末度と強熱減量との関係を論ずる場合には，問 題は，扮のづから別である。

7. 吸着性 9 種の尼ケ崎フライ アッシュについて，1 $\mathrm{g}$ 当りのメチレンブルー吸着量を試験した結果は 表一3・11 のと招りである。委た光電管比色計飞よる方法のみを用い，前記 9 種以外の 6 種の尼ケ崎フライアッ シュについても吸着量を試験したが，との試験結果䄧よび 丧一3・1 の試験結果にむとづきフライ アッシュの炭 素含有量とメチレン ブルー吸着量との関係 を示せば 図一3・11 のと怙りである。

表一3・11招よび 図一3・11から次のことが 認められる。

（1）３種の方法で試験した場合，フライ アッシュのメチレンブルー吸着量は試験方法 とよつてある程度相違している。

これは主として各種試験方法による吸着性試 験が同時行われたものでなく, ある程度の 期間を抬いて行われたものであるとと，およ び各試験方法自体の固有誤差,さらにはこれ らの試験方法にまだ十分習熟してなかつたこ となどによるものと思われる。しかし，フラ イアッシュのメチンンブルー吸着量をフラ イアッシュD対する比で示した場合には, 試験方法が相違してあこの吸着量比はほぼ同 じ值を示している。このことはフライ アッ シュの吸着性を試験した扮もな目的が，その 絶対值を求めるととにあつたのではなく，そ の相対值を求めるにあつたこと，すなわち後 述するようとそれによつてフライアッシュ を用いる $\mathrm{AE}$ コンクリートの単位 $\mathrm{AE}$ 剂量を 決定する場合の一つの“毛のさし”をうるこ とにあつたことを考光ると，これら 3 種のう ちとのいずれを用いても十分飞所期の目的を 達しうることを示すものである。

(2) フライアッシュの吸着性は, その含 有䈐素によるものであるが，吸着性の大小は 必ずしも含有炭素量には比例しない。これは, フライ アッシュによつて含有炭素の活性度

\section{表一3.11 フライ アッシュの吸着性試験結果の一例}

\begin{tabular}{|c|c|c|c|c|c|c|}
\hline \multirow{3}{*}{$\begin{array}{l}\text { フテイ } \\
\text { アッンュ }\end{array}$} & \multicolumn{6}{|c|}{ メチレンブルー吸着量 } \\
\hline & \multicolumn{2}{|c|}{$\begin{array}{l}\text { 光電管比色計 } \\
\text { 訪方法 }\end{array}$} & \multicolumn{2}{|c|}{$\begin{array}{l}\text { 各種標準液との } \\
\text { 比色に上る方法 }\end{array}$} & \multicolumn{2}{|c|}{$\begin{array}{l}\text { ベールの法則を } \\
\text { 適用する方法 }\end{array}$} \\
\hline & $(\mathrm{mg} / \mathrm{g})$ & 比 & $(\mathrm{mg} / \mathrm{g})$ & 比 & $(\mathrm{mg} / \mathrm{g})$ & 此 \\
\hline B & 0.73 & 1.30 & 0.55 & 1.22 & 0.48 & 1.26 \\
\hline C & 0.84 & 1.50 & 0.65 & 1.44 & 0.56 & 1.47 \\
\hline $\mathrm{D}$ & 0.56 & 1.00 & 0.45 & 1.00 & 0.38 & 1.00 \\
\hline E & 0.85 & 1.52 & 0.80 & 1.78 & 0.68 & 1.79 \\
\hline F & 0.76 & 1.36 & 0.65 & 1.44 & 0.58 & 1.53 \\
\hline $\mathrm{K}$ & 0.69 & 1.23 & 0.55 & 1.22 & 0.50 & 1.32 \\
\hline L & $0.24^{*}$ & 0.43 & 0.40 & 0.89 & 0.33 & 0.89 \\
\hline $\mathrm{N}$ & 0.77 & 1.38 & 0.60 & 1.33 & 0.58 & 1.53 \\
\hline $\mathrm{O}$ & 0.48 & 0.88 & 0.45 & 1.00 & 0.41 & 1.08 \\
\hline
\end{tabular}

吸着量比はフライアッンュDに対する比で示す。

備考 *印の試験值は他の 2 方法による值に比べてかなり小さいがこれ は测定の誤差によるものと思われる。

\section{図-3·11 フライ アッシュの炭素含有量と 吸着性亡の関係}

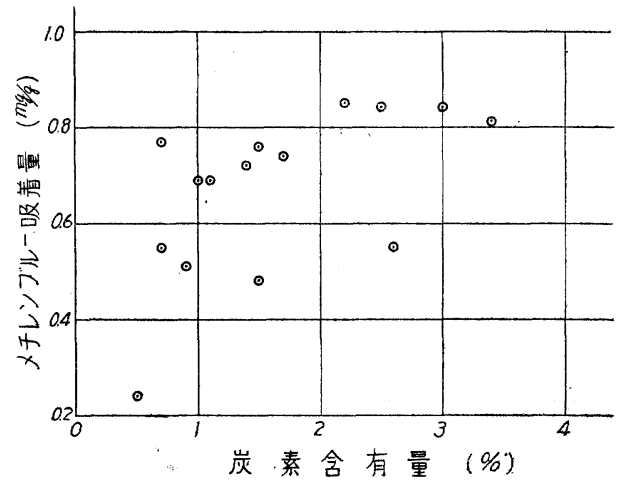


が相違する場合があること並びにフ ライアッシュの吸着性が 含有炭素 量括よびその活性度の関数であると 同特に比表面積の関数でもあること などによるものと思われる。

8. 所要水量比 (所要のフローを うるに必要な水量) 砂の種類抒よび モルタルの配合が相違する5種の基 準配合を用い, フライ アッシュ B・ $\mathrm{C} \cdot \mathrm{N} の 3$ 種について所要水量比を 試験した結果は 表一3・12 亿示すと 呿りである。

表一3・12 から次のことが垫めら れる。

(1) セメントの一部をフライ ア ッシュで招きかえた場合のモルタル の所要水量比は, セメント砂重量比 招よび砂の種類 (豊浦砂と相馬砂) によつてほとえど相違しない。しか し、フライアッシュを扮きか党る 方法炕よつて相違し，重量で据きか える方が容積で扔きがるよりも所 要水量比は大きくなる。これは重量で括きか方場合には，セメントとフライアッシュの比重の差によつて基 準配合の絶対容積よりも，扮きかえたのちのモルタルの絶対容積の方が大きくなるからであると考劣られる。

\begin{tabular}{|c|c|c|c|c|}
\hline \multicolumn{3}{|c|}{ フライ アッンュ } & \multicolumn{2}{|c|}{ 所要水量比 （\%） } \\
\hline 名 称 & $\begin{array}{c}\text { 強熱減量 } \\
(\%)\end{array}$ & $\begin{array}{l}44 \mu \text { フル1 } \\
\text { 残分 }(\%)\end{array}$ & $\begin{array}{l}\text { a 配合を用 } \\
\text { いる場合 } \\
\end{array}$ & $\begin{array}{l}f \text { 配合を用 } \\
\text { いる場合 }\end{array}$ \\
\hline A & 1.6 & 12.0 & 96.8 & 95.0 \\
\hline B & 2.4 & 18.0 & 102.0 & 96.7 \\
\hline $\mathrm{C}$ & 3.0 & 22.8 & 104.4 & 98.7 \\
\hline $\mathrm{D}$ & 2.0 & 15.3 & 97.6 & 97.4 \\
\hline F & 1.9 & 38.4 & 102.0 & 99.4 \\
\hline G & 3.9 & 40.8 & 108.0 & 103.3 \\
\hline $\mathrm{H}$ & 1.9 & 42.4 & 105.9 & 101.7 \\
\hline$L$ & 1.3 & 18.2 & 100.5 & 96.7 \\
\hline M & 1.4 & 15.3 & 99.4 & 98.4 \\
\hline $\mathrm{N}$ & 0.9 & 16.1 & 96.1 & 95.4 \\
\hline $\mathrm{O}$ & 2.4 & 18.3 & 102.0 & - \\
\hline $\mathrm{P}$ & 1.1 & 15.1 & 97.6 & - \\
\hline Q & 0.7 & 13.2 & 96.0 & - \\
\hline
\end{tabular}

\section{図一3·12 フライ アッシュの所} 要水量比
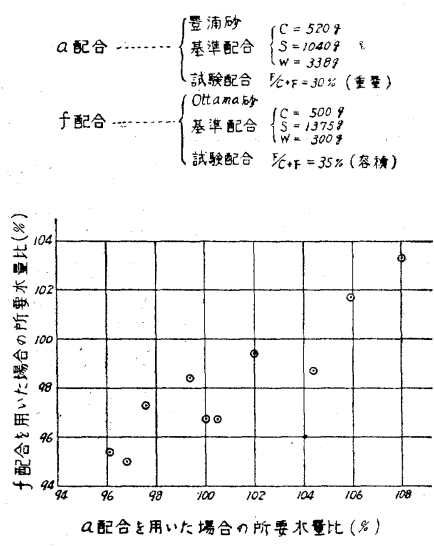

、配合を用いた堨合の所要水比(\%)

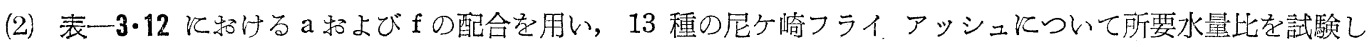

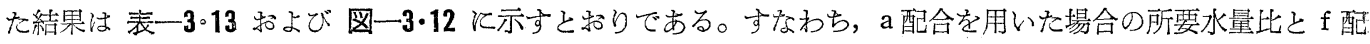
合を用いた場合とれとの間飞はほぼ直線的関係があるととがわかる。また Bureau of Reclamation で要求する $103 \%$ (配合：f）は，a 配合を用いればほぼ 105〜108\%に相当するものと考兄られる。

（3）また図一3.13 は表一3.1 の数值にもとづいて，フライ アッシュの粉末度および強熱減量と所要水量比 （配合を用いた場合）との関係を示したものであつて，傾向としてはフライアッシュの所要水量比はとの粉末 度が細かくなるほど，また強熱減量が少なくなるほど小さくなるととが認められる。 
図一3·13 フライアッシュの粉末度および 強熱減量と所要水量比との関係
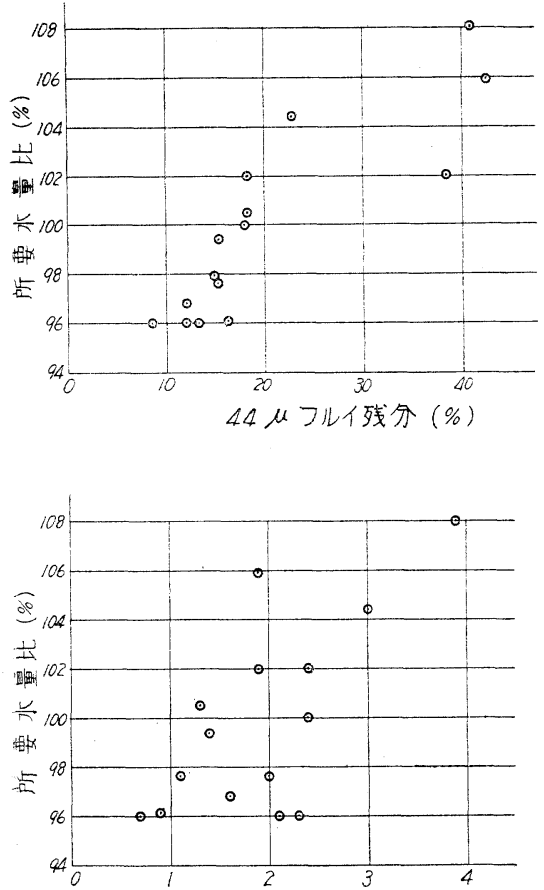

強熱隇量(\%)
表一3·14 石灰・フライ アッシュ砂モルタル 強度試験の結果

\begin{tabular}{|c|c|c|c|c|c|}
\hline \multicolumn{3}{|c|}{ フライ アッンュ } & \multicolumn{3}{|c|}{ 石灰・フライアッシニ砂モルタル } \\
\hline 名 称 & $\begin{array}{c}\text { 強熱減量 } \\
(\%)\end{array}$ & $\begin{array}{l}44 \mu \text { フルイ } \\
\text { 残分 }(\%)\end{array}$ & 砂の種類 & $\begin{array}{l}\text { モルタル中 } \\
\text { の水量 }(\%)\end{array}$ & $\begin{array}{l}\text { 材令 } 7 \text { 日圧縮 } \\
\text { 強度 }\left(\mathrm{kg} / \mathrm{cm}^{2}\right)\end{array}$ \\
\hline A & 1.6 & 12.3 & 相·馬砂 & 12.8 & 82.4 \\
\hline B & 2.4 & 18.0 & " & " & 79.7 \\
\hline $\mathrm{D}$ & 2.0 & 15.3 & " & " & 70.4 \\
\hline $\mathrm{E}$ & 2.6 & 26.2 & $"$ & " & 68.1 \\
\hline F & 1.9 & 38.4 & " & $"$ & 68.3 \\
\hline G & 3.9 & 40.8 & " & " & 53.8 \\
\hline $\mathbf{H}$ & 1.9 & 42.4 & " & " & 58.3 \\
\hline I & 4.3 & 50.8 & " & " & 59.5 \\
\hline $\mathrm{J}$ & 2.8 & 57.6 & " & " & 54.1 \\
\hline $\mathrm{K}$ & 1.5 & 14.9 & " & " & 71.7 \\
\hline $\mathrm{L}$ & 1.3 & 18.2 & $"$ & 13.2 & 71.7 \\
\hline M & 1.4 & 15.3 & " & 13.0 & 72.6 \\
\hline $\mathrm{A}^{\prime}$ & 1.6 & - & Ottawa形少 & 13.2 & 55.8 \\
\hline $\mathbf{N}$ & 0.9 & 16.1 & $"$ & 12.8 & 58.6 \\
\hline O & 2.4 & 18.3 & $"$ & 13.7 & 52.5 \\
\hline
\end{tabular}

フライ アッシュA〜Jについての石灰モルタル試験において

備 考 は, 試験の都合でモルタル中の水量を, フライ アッンュの品

質いかんにかかわらずすべて $12.8 \%$ とした。

9. ポゾラン活性

(1) 石灰フライ アッシュ砂モルタル強度試験の結果 : 15種の尼ケ崎フライ アッシュとついて，石灰ポゾラン 強度試験飞よつてポゾラン活性を武験した結果は 表一3.14 技よび 図一3.14 のと怙りである。

図-3·14 フライ アッシュの粉末度および強熱減量亡 ボゾラン活性との関係
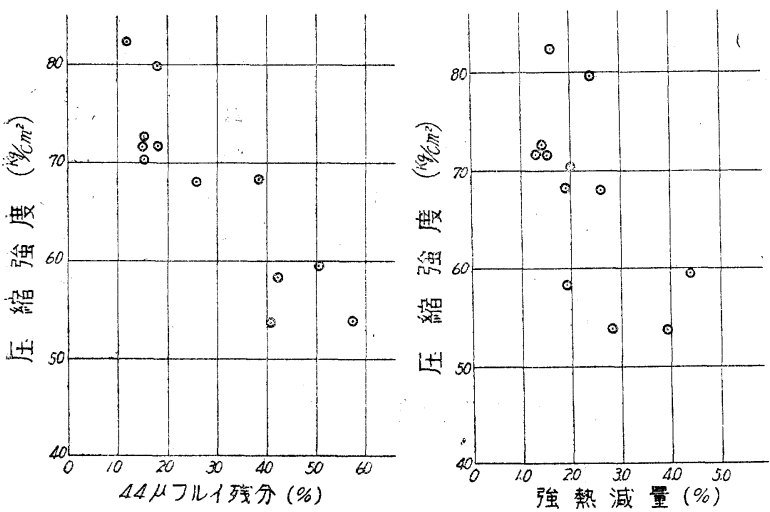

すなわち尼ケ崎フライアッシュはいずれも Bureau of Reclamation の規格合格するポゾラン活性を有し，十分 飞満足すべきものである。フライ アッシュのポゾラン活性 は粉末度が細かく，強熱減量が少ないものほどすぐれている ことがわかる。な特この場合，砂の種類の影響はかなり大き く, 予借試験の結果によれば Ottawa 秒と相馬秒を用いた場 合の強度の比は約 $1: 1.4$ であつた。

(2) セメント・フライアッシュ砂モルタル強度試験の結果
表一3.15 セメント・フライ アッシュ砂 モルタル強度試験の結果

\begin{tabular}{|c|c|c|c|c|}
\hline \multicolumn{3}{|c|}{ フフイアッシニ } & \multirow{2}{*}{$\begin{array}{c}\text { 所要水量 } \\
(\%)\end{array}$} & \multirow{2}{*}{$\begin{array}{c}\text { 王縮強度比 } \\
(\%)\end{array}$} \\
\hline No. & $\begin{array}{c}\text { 強熱減量 } \\
(\%){ }^{2}\end{array}$ & $\begin{array}{l}44 \mu \text { フルイ } \\
\text { 残分 }(\%)\end{array}$ & & \\
\hline 716 & 2.0 & 11.3 & 96 & 102 \\
\hline 719 & 2.7 & 13.6 & " & 103 \\
\hline 721 & 2.3 & 12.0 & $"$ & 106 \\
\hline 722 & 2.1 & 17.9 & $"$ & 101 \\
\hline 726 & 3.0 & 17.8 & $"$ & 103 \\
\hline 728 & 1.8 & 12.5 & $"$ & 98 \\
\hline 730 & 2.1 & 8.7 & " & 105 \\
\hline 82 & 2.2 & 11.9 & " & 105 \\
\hline 84 & 1.8 & 12.5 & $"$ & 102 \\
\hline 86 & 2.4 & 12.2 & " & 105 \\
\hline 89 & 2.3 & 13.2 & $"$ & 103 \\
\hline 811 & 2.4 & 17.5 & $"$ & 100 \\
\hline 826 & 2.1 & 13.3 & " & 101 \\
\hline 831 & 2.3 & 15.7 & $"$ & 103 \\
\hline 93 & 2.0 & 12.9 & " & 106 \\
\hline 96 & 1.8 & 10.6 & $"$ & 98 \\
\hline 備 考 & $\begin{array}{l}\text { フライ } \\
\text { 養生, 材 }\end{array}$ & $\begin{array}{l}\text { V } \\
28 \text { 日 }\end{array}$ & 工率 30 & $40^{\circ} \mathrm{C}$ 密封 \\
\hline
\end{tabular}


: 16 種の尼ケ崎フライ アッシュについて, セメント・フライ アッシュ砂モルタル強度試験方法によつてポゾラ ン活性を試験した結果は 表一3・15 のと和りである。

すなわち，その圧縮強度比はほとんぞ $100 \%$ 以上であつて，これらの尼ケ崎フライアッシュは，すぐれたポ ゾラン活性を有していることがわかる。おた, 強熱減量が約 $3 \%$ 以下, 粉末度が $44 \mu フ ル イ$ 残分で約 $20 \%$ 以下 のフライ アッシュは，ポゾラン活性の点よりみれば，奏用的に同程度とみなすととができる。

10. ポルトランド セメントの㠜結時間飞拉よぼす強響 フライアッシュNo.723 とアサノマスコンセ メントとを用い，JIS R 5201 (セメントの物理試験方法)によつて圾験した結果は表一3・16亿示すと特りである。

表一3・16 フライ アッシュ オキカエ率と凝結時間

\begin{tabular}{|c|c|c|c|c|c|c|c|c|}
\hline ヘீ & x & の & 配 & & ペーストの単 & 凝 & 結 & 間 \\
\hline $\begin{array}{l}\text { フライアッジ } \\
\text { オキカエ率 }(\%)\end{array}$ & $\begin{array}{l}\text { セメント } \\
(\mathrm{g})\end{array}$ & フライ & $(\mathrm{g})$ アンニ & $\begin{array}{l}\text { 水 } \\
(\mathrm{g}) \\
\end{array}$ & 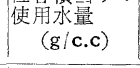 & $\begin{array}{l}\text { 㛎 } \\
\text { (姷一発) }\end{array}$ & \begin{tabular}{|l} 
桻 結 \\
(封一分)
\end{tabular} & 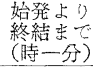 \\
\hline 0 & 400 & & 0 & 102 & 0.449 & $3-10$ & $4-40$ & $2-20$ \\
\hline 10 & 360 & & 40 & 104 & 0.440 & $3-25$ & $5-15$ & $1-50$ \\
\hline 20 & 320 & & 80 & 107 & 0.433 & $3-45$ & $5-55$ & $2-10$ \\
\hline 30 & 280 & & 120 & 110 & 0.427 & $4-00$ & $6-25$ & $2-25$ \\
\hline 40 & 240 & & 160 & 114 & 0.424 & $5-00$ & $7-30$ & $2-30$ \\
\hline 50 & 200 & & 200 & 119 & 0.421 & $6-30$ & $9-10$ & $2-40$ \\
\hline
\end{tabular}

試験の結果によれば, フライアッシュオキカエ率が増大するにつ れて始発終結ともに延びているが，始発から終結までの時間は大して 変つていない。

な杼，水量がフライアッシュオキカ工率比比して増加している が，これは重量比でセメントの一部を和きかえたためにセメント十フ ライ アッシュの絶対容積がフライ アッシュオキカエ率に比例して 增加することによるものと考光られる。

11. ポルトランドセメントの安定性法よばす影響 表一3・17は 尼ヶ崎フライ アッシュがポルトランド セメントの安定性飞和よぼす 影響を ASTM : C151-52 (ポルトランド セメントのオートクレーブ 膨脹試験方法) 飞準じて試験した結果である。

すなわち, 中庸熱ポルトランド セメント(アサノ マスコン セメン ト）招よび普通ポルトランドセメント（磐城セメント）の一部をフ ライアッシュで和きかえた場合, オートクレーブ膨脹試験飞よる安 定性は，オキカエ率関せず，ほぼ同程度である。

12. ポルトランド セメントの水和熱炕よぼす影響 セメント(ア サノマスコンセメント) 重量の $20 \%$ 物よび $40 \%$ を特きかえた試料 そついて, JIS R5203 (セメントの水和熱測定方法) 飞準じて試験を 行つた。
表一3・17 フライアッシュ オキカエ率と安定性

\begin{tabular}{|c|c|c|}
\hline $\begin{array}{l}\text { フライアッジ } \\
\text { オキカ工率 }\end{array}$ & 水 $(\%)^{\text {量 }}$ & $\begin{array}{c}\text { オートクレ゙ } \\
\text { ブによる膨脹 } \\
(\%)\end{array}$ \\
\hline \multicolumn{3}{|c|}{ 中庿熱ポルトラント゚ セメント使用 } \\
\hline 0 & 23.0 & -0.01 \\
\hline 10 & 23.6 & -0.03 \\
\hline 20 & 24.2 & -0.02 \\
\hline 30 & 25.0 & -0.01 \\
\hline 40 & 26.0 & -0.01 \\
\hline 50 & 27.0 & +0.01 \\
\hline 普通ポルトランド & \multicolumn{2}{|c|}{ セメント使用 } \\
\hline 0 & 24.0 & 0.23 \\
\hline 10 & 24.3 & 0.15 \\
\hline 20 & 24.8 & 0.11 \\
\hline 30 & 25.3 & 0.09 \\
\hline 40 & 26.0 & 0.04 \\
\hline 50 & 27.0 & 0.04 \\
\hline
\end{tabular}

表一3・18 フライ アッシュがポルトランド セメントの水和熱におよぼす影響

\begin{tabular}{|c|c|c|c|c|c|c|c|c|}
\hline \multirow[b]{2}{*}{$\begin{array}{l}\text { フライアッシュ } \\
\text { オキカエ率 }(\%)\end{array}$} & \multirow{2}{*}{$\begin{array}{l}\text { 末水和セメント・ } \\
\text { フライ アッシュ } \\
\text { の溶解熱 (cal/g) }\end{array}$} & \multicolumn{2}{|c|}{ 水 稆 1 熱 } & \multicolumn{3}{|c|}{$\begin{array}{c}\text { 溶解熱測定時の不溶残分 } \\
(\%)\end{array}$} & \multicolumn{2}{|c|}{ フライ アッシュの水和熱 } \\
\hline & & 材令 & 材令 & 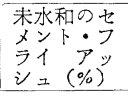 & 材令 & 材令 & $\begin{array}{l}\text { 材 } \\
7 \text { 日 }\end{array}$ & $\begin{array}{c}\text { 材 令 } \\
28 \text { 日 }\end{array}$ \\
\hline 0 & 600.9 & $\begin{array}{l}61.3 \\
(100 \%)\end{array}$ & $\begin{array}{l}79.1 \\
(100 \%)\end{array}$ & 0 & 0 & 0 & - & - \\
\hline 20 & 561.0 & $\begin{array}{c}51.5 \\
(84 \%)\end{array}$ & $\begin{array}{c}68.4 \\
(86 \%)\end{array}$ & 6.12 & 5.96 & 5.91 & 13 & 26 \\
\hline 40 & 521.4 & $\begin{array}{c}42.8 \\
(70 \%)\end{array}$ & $\begin{array}{c}57.8 \\
(73 \%)\end{array}$ & 11.84 & 12.00 & 11.92 & 15 & 26 \\
\hline 備 & $\begin{array}{l}\text { フライ アッン } \\
\text { つて求めた。 }\end{array}$ & 水和熱 & フライ & アッンニ オ & カ工率 $0 \%$ & るける水和 & 热を基準と & 計算によ \\
\hline
\end{tabular}


試験を行うに当つて, シリカセメントは材令によつて不溶残分が異なり，溶け終るまでに規定以上の時間が かかるので，正確にはこの方法を適用することができない点を考虑して，セメント・フライ アッシュを溶解す るときと，フッ化水素酸の量を 1.5 倍用いて試験を行つた結果，セメント・フライアッシュの未水和のときの 不溶残分と，7日抒よび 28 日の水和作用を行つたときの不溶残分とがほぼ等しい值になつた。従つて，不溶残 分の水和熱标よぼす影響は互いに消去するものと考光られる。表一3・18はこの方法によつて試験した場合の結 果である。

表一3・18 から，フライ アッシュでセメント重量の $20 \%$ 技よび $40 \%$ を怙きかえたセメント・フライアッシュ

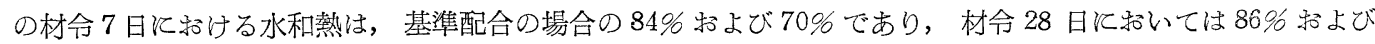
$73 \%$ であるととがわかる。これより，セメントとともに用いた，フライアッシュは，それ自身で材令 7 日では $14 \mathrm{cal} / \mathrm{g}$ ，材令 28 日では $26 \mathrm{cal} / \mathrm{g}$ の水和熱を発生すること枋るすなわち,フライ アッシュがセメントの遊 離石灰などと反応するときの水和熱はセメントの水和熱よりいちじるしく小さく，セメント・フライアッシュの 水和熱は, フライアッシュオキカエ率比比して減少する。

\section{IV. コットレル系フライ アッシュがコンクリートの性質におよぼす影響}

\section{〔1〕コンクリートおよび試験方法}

1. コンクリート材料

（1）セメント：セメントは，主として小野田セメントK K 津久見第二工場の普通ポルトランド セメントを用 いたが，一部の試験では小野田セメント K K 津久見第二工場の中庸熱ポルトランド セメント・日本セメント $\mathrm{K}$ K西多摩工場のアサノ マスコン セメント・磐城セメントK K 七尾工場の普通ポルトランド セメントならびに中 庸熱ポルトランド セメント怙よび同社浜松工場の中庸熱ポルトランド セメントなども用いた。これらの試験成 績は 表一4・1 亿示すと打りである。

表一4・1 用いたセメントの試験 成績

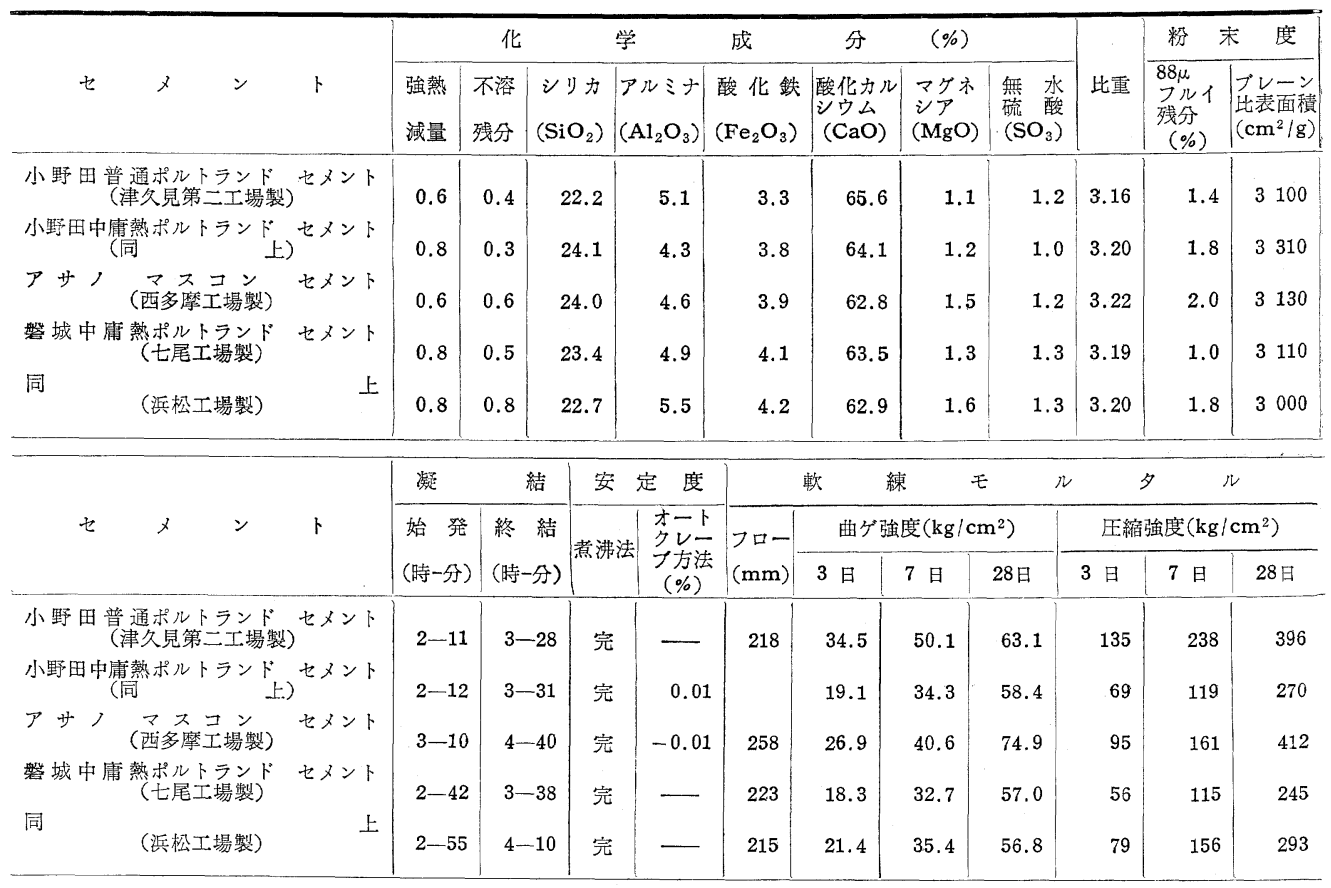

（2）砂：砂は淀川産・大和川産・糧保川産・天龍川産㧍よび相模川産などで,それらの招むな試験成績は 表一 $4 \cdot 2$ 飞示すと拈りである。砂の使用飞当つては，天日で乾燥したものを粒の大きさによつて 2 種もしくは 3 種に ふるい分け，それらを一定の割合々混ぜて用いた。砂は幹燥状態のままで使用し，有效吸水量泪当する水は， 練り混ぜ水の方飞加えた。な招, 砂の粒度がフライ アッシュを用いたコンクリートのコンシステンシー招よび 強度に扮よぼす影響をたしかめるために行つた試験では，表一4・2 亿示した粒度以外のものを用いたが，それら そついてはそのところで述べる。 
（3）砂利：砂利は日高川産・那賀川産・日 置川産・天龍川産抽よび相模川産であるが最 大寸法は実験の目的飞応じて変え, 最大寸法 を $15 \cdot 25 \cdot 30 \cdot 40 \mathrm{~mm}$ とした場合には日高 川産・那賀川産・相模川産のものを，80 mm とした場合には日置川産のものを，150 mm とした場合には天龍川産のものを用いた。そ れらの招もな試験成績は表一 $4 \cdot 3$ 亿示すと扮 りである。砂利の使用当つては，あらかじ めらるい分けて和いたものを表一4·3 亿示 す粒度に配合し，かつ十分に吸水させた粒の 表面を布でふき表面乾燥飽和状態として用い た。ただし，最大寸法が $80 \mathrm{~mm}$ 挌よび 150 $\mathrm{mm}$ の場合には気乾状態のま恋用い, 有効吸 水量泪当する水は練り混ぜ水の方飞加光 た。

(4) AE 郕: AE 刘は Hercules Powder Co. 製のビンソル レジン特よびドレシネー トXを用いた。その使用当つては，ともに

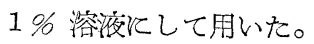

2. コンクリート

(1) 配合：試験に用いたコンクリートの品 質は，主として中庸の気候の土地造られる 普通の構造物とダムの内部コンクリートをめ

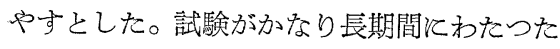
ために, その間コンクリート材料も種々変り, コンクリートの配合も多種多様に変化した が，試験の結果を論ずるに当つては常にフラ イアッシュを用いた場合と用いない場合の コンクリートの品質の比較を目的としたの
表一4・2 用いた砂の試験結果

\begin{tabular}{|c|c|c|c|c|c|c|}
\hline 区 & 分 & 淀川産 & $\begin{array}{l}\text { 大和川 } \\
\text { 産 }\end{array}$ & $\begin{array}{l}\text { 樶保川 } \\
\text { 産 }\end{array}$ & $\begin{array}{l}\text { 天龍川 } \\
\text { 産 }\end{array}$ & $\begin{array}{l}\text { 相模川 } \\
\text { 産 }\end{array}$ \\
\hline 比 & 重 & 2.58 & 2.56 & 2.57 & 2.66 & 2.60 \\
\hline \multicolumn{2}{|c|}{ 吸水量 $(\%)$} & 1.3 & 1.6 & 2.5 & 1.3 & 2.9 \\
\hline \multirow{6}{*}{$\begin{array}{l}\text { フルイ } \\
\text { に止る } \\
\text { 量の百 } \\
\text { 分率 }\end{array}$} & 5 & 0 & 0 & 0 & 0 & 0 \\
\hline & 2.5 & 7 & 7 & 12 & 5 & 9 \\
\hline & 1.2 & 28 & 26 & 29 & 29 & 31 \\
\hline & 0.6 & 59 & 58 & 54 & 55 & 60 \\
\hline & 0.3 & 89 & 88 & 85 & 74 & 79 \\
\hline & 0.15 & 98 & 97 & 96 & 91 & 98 \\
\hline 粗 & 率 & 2.81 & 2.76 & 2.76 & 2.54 & 2.77 \\
\hline
\end{tabular}

表一4・3 用いた砂利の試験結果

\begin{tabular}{|c|c|c|c|c|c|c|c|c|}
\hline 区 & 分 & 日 & 高 川 & 痤 & $\begin{array}{l}\text { 邵賀川 } \\
\text { 䨾 }\end{array}$ & $\begin{array}{l}\text { 旦置川 } \\
\text { 應 }\end{array}$ & $\begin{array}{l}\text { 天龍川 } \\
\text { 産 }\end{array}$ & $\begin{array}{l}\text { 相模川 } \\
\text { 産 }\end{array}$ \\
\hline 此 & 重 & \multicolumn{3}{|c|}{2.61} & 2.62 & 2.60 & 2.70 & 2.68 \\
\hline \multicolumn{2}{|c|}{ 吸水量 $(\%)$} & \multicolumn{3}{|c|}{1.3} & 1.0 & 1.2 & 0.7 & 1.4 \\
\hline \multicolumn{2}{|c|}{ 最大寸法(mm) } & 15 & 25 & 30 & 30 & 80 & 150 & 40 \\
\hline \multirow{9}{*}{$\begin{array}{l}\text { フル } \\
\text { 老通る } \\
\text { 量の百 } \\
\text { 分率 }\end{array}$} & 150 & & & & & & 100 & \\
\hline & 80 & & & & & 100 & 68 & \\
\hline & 40 & & & & & 60 & 42 & 100 \\
\hline & 30 & & & 100 & 100 & - & - & - \\
\hline & 25 & & 100 & - & - & - & - & 71 \\
\hline & 20 & & 80 & 75 & 72 & 30 & 22 & 50 \\
\hline & 15 & 100 & - & - & - & - & - & 31 \\
\hline & 10 & 50 & 30 & 25 & 22 & 10 & 9 & 12 \\
\hline & 5 & 0 & 0 & 0 & 0 & 0 & 0 & 0 \\
\hline
\end{tabular}

で，その点関してはなえら支障ないものと考光る。

試験に用いたコンクリートの粗骨材の最大寸法は $15 \cdot 25 ・ 30 \cdot 40 \cdot 80 \cdot 150 \mathrm{~mm}$ の 6 種で, $15 \cdot 25 \cdot 30 \cdot 40 \mathrm{~mm}$ のコンクリートは単位セメント・フライ アッシュ量を $239 \sim 356 \mathrm{~kg} / \mathrm{m}^{3}$ とし，スランプを約 $6 \mathrm{~cm}$ (ただし一 部の試験では $2 \mathrm{~cm}$ 执よび $4 \mathrm{~cm}$ とした)， $\mathrm{AE}$ コンクリートの場合の空気量は約 $5 \%$ とした。また $80 \mathrm{~mm}$ 扔 よび $150 \mathrm{~mm}$ のコンクリートは単位セメント・フライ アッシュ量を $160 \mathrm{~kg} / \mathrm{m}^{3}$ 执よび $180 \mathrm{~kg} / \mathrm{m}^{3}$ とし，スラ ンプを約 $4 \mathrm{~cm}$, 空気量は約 $4 \%$ とした。

全シリーズの実験を通じて，フライアッシュを用いる場合には，基準配合のセメントの一部をフライアッシ

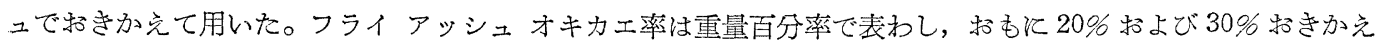
たものについて試験を行つたが，一部では $10 ・ 40 ・ 50 \%$ のももある。フライ アッシュを用いた場合のコン クリートの単位水量は, 粗骨材の使用量を基準配合と等しく保ちながら所定のスランプが得られるようと試的方 法によつて求めた。また $\mathrm{AE}$ コンクリートにフライ アッシュを用いた場合の単位 $\mathrm{AE}$ 郕量は，基準配合と等し い空気量が得られるよう飞試的方法によつて求めた。

実験用いたコンクリートの配合は，相当種類が多いのでそのたでごとに表示する。

（2）練り混ぜ拉よびまだ固まらないコンクリートの試験：AE 骫を用いないコンクリートは，バッチの大きさ を $20 l$ もしくは $24 l$ とし,すべて手練りで練り混ぜた。粗骨材の最大寸法が $25 \mathrm{~mm}$ 括よび $30 \mathrm{~mm}$ の AE コンクリートは, 1 バッチの大きさを $20 l, 80 \mathrm{~mm}$ のコンクリートは $36 l$ とし, ともとコーン型 2 切可傾式ミ キサを用いて全材料を投入後 4 分間練り混ぜた。ただし最大寸法 $80 \mathrm{~mm}$ のコンクリートを練る場合には前記 2 切ミキサのブレードの形状を変え（一組 3 枚のブレードをすべてボルト締めにして掠き必要に応じて適宜この枚 
数を加減するようにした）一応支障のないようにした。また最大寸法 $150 \mathrm{~mm}$ のコンクリートは, 1 バッチの大 きさを $100 l$ とし，ゼガー型 8 切可傾式ミキ辛用いて全材料を投入後 3 分間練り混ぜた。な拈最大寸法 $80 \mathrm{~mm}$ および $150 \mathrm{~mm}$ のコンクリートは，ミキサより排出後ただちに $40 \mathrm{~mm}$ 板フイルによつて $40 \mathrm{~mm}$ 以上の骨材を 取り除き,さらに手練りで練り直した。

これらのコンクリートそついて，スランプ拉よ゙空気量を試験するとともに，目的に応じて圧縮強度試験・凍 結融解試験・透水試験・断熱温度上岽試験などの供試体を造つた。一部の試験と括いては,リモールジング試験 㧍よびブリージング試験を行つた。リモールジング試験は Powers の方法に, ブリージング試験は ASTM の 標準試験方法試案飞準じて行つた。リモールジング試験を行つたのは，ある種の混和材を用いたコンクリートと それを用いないコンクリートのウォーカビリチーを比較する目的に対しては，スランプ武験が必ずしも適当なも のではないといわれているからであつた。またコンクリートの空気量はすべて容積方法で試験した。

練り混ぜたときのコンクリートの温度は, 試験の期間が相当長期間にまたがつたので $7 \sim 27^{\circ} \mathrm{C}$ の範囲飞変化し たが，1シリーズの試験は約 7〜14 日の間に行つてその間に㧍ける試験の諸条件を一定に保つようにし，フライ アッシュを用いたコンクリートと用いないコンクリートの品質を比較する目的に対して支障のないようにした。

3. 強度試験方法

（1）圧縮強度試験方法 : 圧縮強度試験飞用いた供試体は $15 \times 30 \mathrm{~cm}$ 円柱供試体呿よび $10 \times 20 \mathrm{~cm}$ 円柱供試体 の 2 種類である。供試体の寸法は, 粗骨材の最大寸法・実験の目的および めたが，主として $15 \times 30 \mathrm{~cm}$ 円柱供試体は，最大寸法 $30 \mathrm{~mm}$ 以上のコンクリートを，10×20 cm 円柱供試体 は最大寸法 $25 \mathrm{~mm}$ のコンクリートをそれぞれ対象とした。供試体は成形後 2 日間空気中に打いたのち脱ワク し, 試験時まで $20 \pm 3^{\circ} \mathrm{C}$ の水中で養生した。な摻養生条件がフライ アッシュを用いたコンクリートの圧縮強度 そ怙よぼす影響を比較する試験では, $20^{\circ} \mathrm{C}$ 水中養生のほかに $38^{\circ} \mathrm{C}$ 水中養生拈よび冬期寒冷な気候時を利用し た低温水中養生を行つた。

試験の材令は主として 28 日・91 日・6月・1年としたが，一部の試験では 7 日括よび 2 年をもをの対象と した。試験値は供試体 3 個の平均值をとつた。

（2）引張強度試験方法: 引張強さ係数試験に用いた供試体は $15 \times 23 \mathrm{~cm}$ 円柱供試体で $15 \times 30 \mathrm{~cm}$ 円柱供試 体用型ワクを用いて製造した。供試体は製造後 2 日間空気中に䅂いたのち脱ワクし，試験時采で $20 \pm 3^{\circ} \mathrm{C}$ の水 中で養生した。試験は材令 7 日・28 日・91日・6月・1 年で行い, 試験值は供試体 4 個の平均值をとつた。

4. 透水武験方法抢よび耐透水指数 透水試験は著者の構想によつて円井製作所㧍よび丸東製作所に製作させ た, 中空厚肉円筒方式透水試験装置を用いて行つた。試験装置は 写真一 $4 \cdot 1 \sim 4 \cdot 5$ 亿示すとおりである。写真一 4.1 の円井製作所製の透水試験機は, 圧力源として窒素ガス ボンベを用い, 窒素ガス圧力を水圧に切り換える 二次タンクおよび試験槽をとの主要部分とする。試験水圧の自動調節装置は使用してないが，あらかじめ透水試 験時に括ける供試体からの流出量を想定し，1〜3 日程度放置して招いても水圧の低下が試験誤差の範囲にとど まるように二次タンクの窒素ガスの容量を設計したので，実用上なんら支障はない。

写真一 $4 \cdot 2$ の丸東製作所製の透水試験機は, この種透水試験装置のうち加圧方式として荷重式蓄圧装置による 定水圧機構を備光たものである。これらの透水試験機はともに供試体 3 個を同時飞試験しうるものである。

供試体は $15 \times 30 \mathrm{~cm}$ 円柱の中心值径 $2.0 \mathrm{~cm}$ の孔をつ中空円筒供試体である。型ワクは $15 \times 30 \mathrm{~cm}$ 円柱

写真一4・1 窒素ガス ボンベを用いた透水試験装置

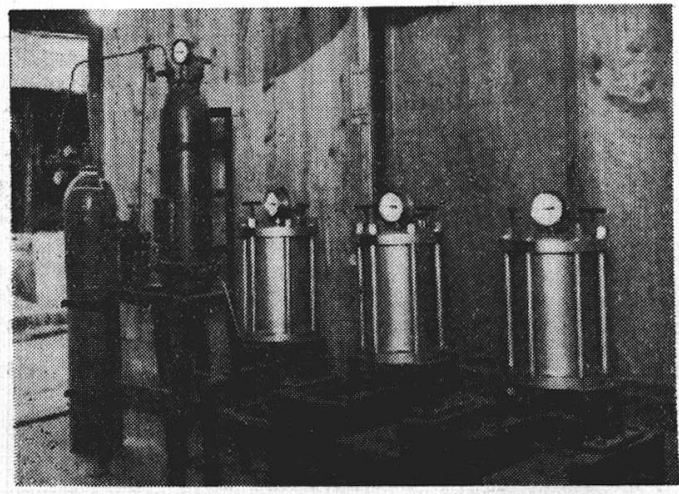

写真一4.2 荷重蓄圧方式による透水試験装置

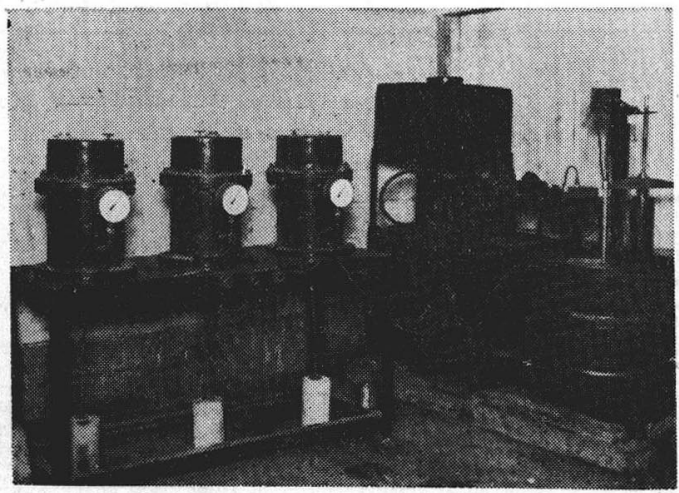


供詿体製造用型ワクの中心軸儿直径 $2.0 \mathrm{~cm}$ の丸棒を 写真一4.3 亿示すように固定したものを用い，供試体の 製造は圧縮強度試験用供試体飞準じて行つた。供試体の中心孔の直径を $2.0 \mathrm{~cm}$ としたのは, 主として供試体製 造の容易さ㔚よび用いるコンクリートの粗骨材の最大寸法などを考慮したものである。

製造した供試体は，写真一 $4 \cdot 4$ 亿示す脱棒装置を用いて中心の丸棒を抜き取り，その翌日キャッピングを行つ た。キャッピングに際しては，コンクリートとペーストとの間に空隚が生ずるのを防ぐため，末ず十分とレイタ ンスを取り除いたコンクリート表面に, 水セメント重量比約 $34 \%$ 程度のペーストを入念䏓うしさつめ, そ ののち水セメント重量比が約 $28 \%$ のペーストでいわゆるガラスキヤッピングを行つた。

透水試験は材令 28 日・60日・91日・4月でそれぞれ開始した。特に長期材令のコンクリートについて行わな かつたのは, この試験に用いたコンクリートの水セメント重量比程度では, 試験水圧を $30 \mathrm{~kg} / \mathrm{cm}^{2}$ としても試験

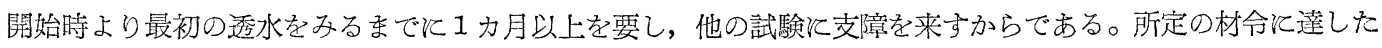

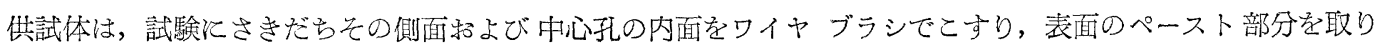
除いた。供試体を試験槽に据付けるに際しては，供試体の上下端面と試験装置との境界面をゴムパッキングお よびアスファルトなどを介して十分にボルトで締めつけ，上下端面を水密に保つた (写真一 $4 \cdot 5$ 参照)。試験水圧 は早期材令に招いては主として $15 \mathrm{~kg} / \mathrm{cm}^{2}$ ，長期材令に和いては $30 \mathrm{~kg} / \mathrm{cm}^{2}$ とした。

一般に 1 時間ごとに供試体よりの流出量を測定し, 流出量がほぼ一定值を示すまで継続した。供試体1個の試 験汇要した日数は2 30日であるが, 試験水圧をかけてから最初の透水をみるまでにある程度のアソビ時間 (dead time) があり，乙れはコンクリートの透水性によつていらじるしく相違する。特に流出量が少ない場合には, 集 水メス シリンダよりの水分の蒸発が試験值飞影響するようになるので，あらかじめメス シリンダに軽油を数滴 入れて和き，水面軽油の被膜をつくるととによつて水分の蒸発を防いだ。試験は早期材令に扔いては供試体 2 個を用い長期材令飞和いては供試体 1 個を用いた。

透水詿験の結果は, 平均流出量拈よびそれてもとずいて算出した透水係数ならびそ耐透水指数で整理した。透 水係数扔よび耐透水指数は $20^{\circ} \mathrm{C}$ 飞招ける $\mathrm{cm}$ ・秒を基準とした值で表わすすのとし，次式で計算した。

$$
\text { 透水係数 }: K=\frac{\mu}{\mu_{20}} \frac{\rho \log e r_{0} / r_{i}}{2 \pi h} \frac{Q}{P_{0}-P_{i}}
$$

而过透水指数 $: p K=-\log _{10} K$

ここV $K:$ 供試体の透水係数 $(\mathrm{cm} /$ 秒 $)$

$P_{0}:$ 供試体の外側沱ける水圧 $\left(\mathrm{kg} / \mathrm{cm}^{2}\right)$

$P_{i}:$ 供試体の内側䏕ける水圧 $\left(\mathrm{kg} / \mathrm{cm}^{2}\right)$

$Q:$ 流出量 $(\mathrm{cc} /$ 秒 $)$

$\rho:$ 水の単位容積重量 $\left(\mathrm{kg} / \mathrm{cm}^{3}\right)$

$h:$ 供試体の高さ $(\mathrm{cm})$

$r_{0}:$ 供試体の半径 $(\mathrm{cm})$

$r_{i}:$ 供武体の中心孔の半径 $(\mathrm{cm})$

$\mu$ : 試験時温度飞招ける水の粘性係数 $(\mathrm{g} / \mathrm{cm}$ ・秒)

$\mu_{20}: 20^{\circ} \mathrm{C}$ 飞打ける水の粘性係数 $(\mathrm{g} / \mathrm{cm}$ ・秒 $)$

$p K$ : 供試体の耐透水指数

表一4.4 コンクリートの透水試験結果の一例

\begin{tabular}{|c|c|c|c|c|c|c|c|c|c|c|c|c|c|c|c|c|c|}
\hline \multirow{2}{*}{$\begin{array}{l}\text { 水セメ } \\
\text { ント比 } \\
\end{array}$} & \multirow{2}{*}{$\begin{array}{l}\text { 単位セx } \\
\text { ント量 } \\
\left(\mathrm{kg} / \mathrm{m}^{3}\right)\end{array}$} & \multirow{2}{*}{$\begin{array}{l}\text { 単位水量 } \\
\left(\mathrm{kg} / \mathrm{m}^{3}\right)\end{array}$} & \multirow{2}{*}{$\begin{array}{l}\text { スラン } \\
7^{\circ} \\
(\mathrm{cm})\end{array}$} & \multirow{2}{*}{$\begin{array}{c}\text { 空気星 } \\
(\%)\end{array}$} & \multirow{2}{*}{$\begin{array}{c}\text { 試験開 } \\
\text { 始材令 } \\
\text { (日) }\end{array}$} & \multirow{2}{*}{$\begin{array}{l}\text { 試騟水圧 } \\
\left(\mathrm{kg} / \mathrm{cm}^{2}\right)\end{array}$} & \multirow{2}{*}{$\begin{array}{l}\text { 試驗 } \\
\text { 水温 } \\
\left({ }^{\circ} \mathrm{C}\right)\end{array}$} & \multirow{2}{*}{$\mid \begin{array}{cc}\text { アソビ } \\
\text { 時 } & \text { 間 } \\
\text { (時) }\end{array}$} & \multirow{2}{*}{\begin{tabular}{|l|} 
平均 \\
流出量 \\
(cc/持)
\end{tabular}} & \multirow{2}{*}{\begin{tabular}{|c|} 
平均流出 \\
量算出時 \\
の材命 \\
(日)
\end{tabular}} & \multicolumn{2}{|c|}{ 供試体重量 (kg) } & \multirow{2}{*}{$\begin{array}{l}\text { 压入 } \\
\text { 水量 } \\
(\%)\end{array}$} & \multirow{2}{*}{\multicolumn{2}{|c|}{ 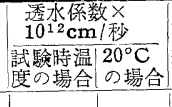 }} & \multirow{2}{*}{ 耐䢩水 } & \multirow{2}{*}{$\begin{array}{l}\text { 㭝令28日 } \\
\text { 圧縮強度 } \\
\left(\mathrm{kg} / \mathrm{cm}^{2}\right)\end{array}$} \\
\hline & & & & & & & & & & & 試験前 & 試験後 & & & & & \\
\hline 0.51 & 180 & 91.0 & 4.1 & 3.3 & 28 & 15 & 20 & 620 & 0.02 & 69 & 12.218 & 12.432 & 4.1 & 3.8 & 3.8 & 11.4 & \\
\hline$\Rightarrow$ & " & 91.5 & 5.8 & 4.1 & 29 & " & 17 & & 仿僟 & 障 & 中止 & & & & & & 203 \\
\hline 0.58 & 160 & 93.5 & 6.0 & 4.1 & 28 & " & 10 & 80 & 0.45 & 34 & 11.820 & 12.058 & 4.6 & 89 & 120 & 9.9 & 147 \\
\hline " & " & 93.5 & 5.2 & 3.9 & 28 & $"$ & 10 & 55 & 0.46 & 34 & 11.997 & 12.232 & 4.5 & 91 & 120 & 9.9 & 156 \\
\hline 0.65 & 140 & 91.0 & 4.0 & 4.4 & 29 & " & 13 & 20 & 1.25 & 35 & 11.822 & 12.095 & 5.2 & 250 & 300 & 9.5 & 116 \\
\hline$"$ & " & 91.5 & 4.2 & 4.2 & 29 & " & 13 & 23 & 1.46 & 35 & 11.723 & 12.000 & 5.3 & 290 & 350 & 9.5 & 113 \\
\hline
\end{tabular}

備考 1. 用いた数骨材の最大寸法位 $150 \mathrm{~mm}$ ，セメントはイワキ中庸熱ポルトランドセメント(浜松工場製)である。

2. 透水試験は $20 \mathrm{~mm}$ 以上の骨材を方るい去つたコンクリートについて試験した。 
コンクリートの透水試験の結果を数量的に表わす場合， $K$ の值は，例光ば $10^{-6} \sim 10^{-13}$ というようなオーダー の差として現われてくる。従つて，てれの前につけられる有効数字例光ば $3.8,9.6$ などのみをとつて透水係数 を論ずるととは当を得たものでない。流出量または透水係数をもつて試験結果を整理するときには，その本質を 見のがすととがある。本論文においてはとれゆ光耐透水指数是用いるとととした。この值は透水係数の負の才一 ダーの高さ，まなわち耐透水性を示す值である。

水セメント重量比 $0.51 \cdot 0.58 \cdot 0.65$, スランプ約 $5 \mathrm{~cm}$, 空気量約 $4 \%$ の AE コンクリートについて前記の方法 飞従つて透水試験を行つた結果は 表一 4.4 亿示すと和りであつて, 透水の程度と他の諸量例えば 水セメント重 量比拉よび単位セメント量との関係は耐透水指数を通じて, きわめて明確に把握することができるとともに, こ の試験方法が十分信頼できるものであることを知るものである。

5. 逨結融解試験方法 逨結融解試験装置(写真一4·6) は三菱電機 K K V製作させたもので, ASTM : C 290$52 \mathrm{~T}$ の標準試験方法試案飞準じて逨結融解試験を行う場合, 16 個の供試体 $(10 \times 10 \times 42 \mathrm{~cm}$ 角柱) 飞対し, 1 日に 10 12 サイクルの逨結融解を全自動的に行いうる能力を有するものである。試験装置は大別して武験槽・ 高温ブラインタンク・低温ブライン タンタ・機械室・制御装置からなつている。

\section{写真一4・3 透水試験用供試} 体成形型ワク

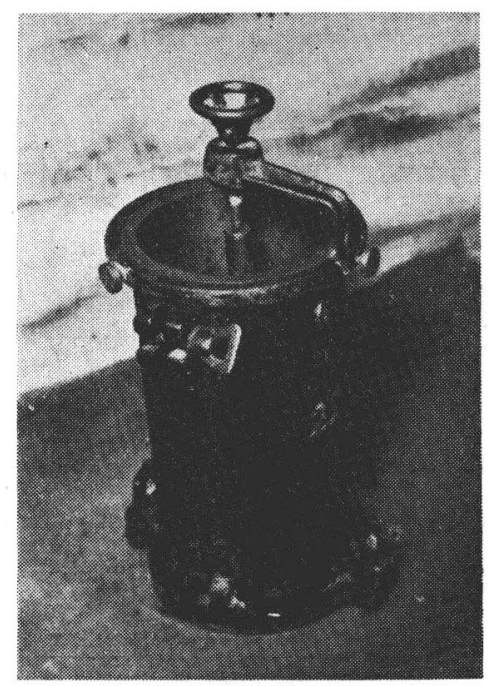

写真一 $4 \cdot 5$ 透水試騃用供試 体の聚付け状況

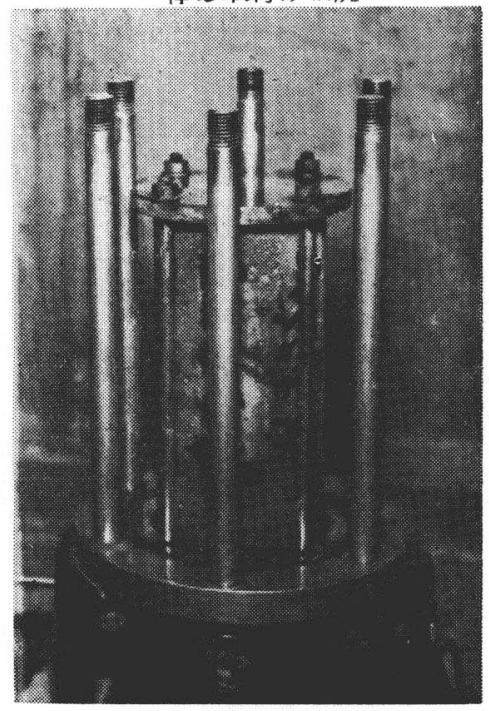

写真一 $4 \cdot 4$ 透水試験用供試 体中心孔脱棒装置

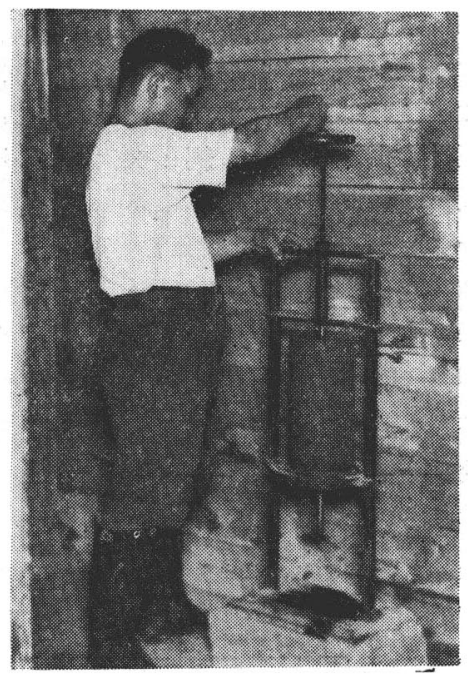

\section{写真一4.6 凍結融解試馱装置}

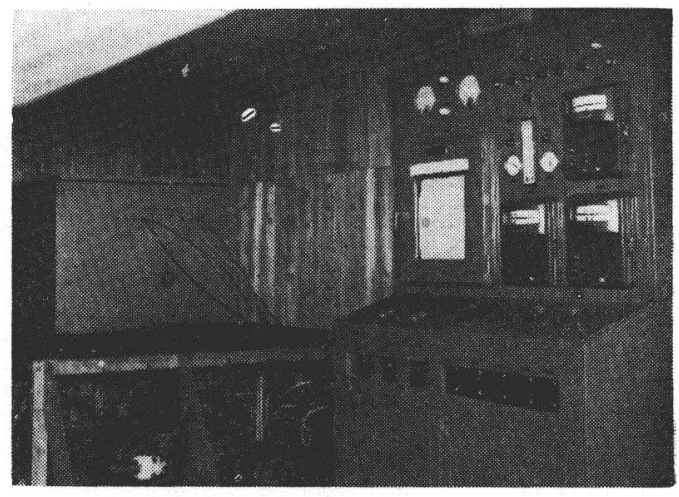


供試体は製造後 2 日間空気中で養生したのち脱ワクし, 試験開始時まで $20 \pm 3^{\circ} \mathrm{C}$ の水中養生を行つた。ただ 乙脱ワクするまでの 2 日間は供試体を湿布で招招い，室温のままで養生した。楝結融解試験を開始した材令はフ ライアッシュを用いたコンクリートの特性を考虑して，早期材令（28日）と長期材令（3月１1 月）とに区別 した。

凍結融解試験は ASTM : C 290-52 T 25 ) 標準試験方法試案に準じて行つた。供試体中心部の温度は, 凍結時で $-17.5 \pm 1.5^{\circ} \mathrm{C}$, 融解時で $4.5 \pm 1.5^{\circ} \mathrm{C}$ とし, 供試体の谏結には約 $-18^{\circ} \mathrm{C}$ の塩化カルシウムブラインを, 融解 には約 $10^{\circ} \mathrm{C}$ の塩化カルシウムブラインをそれぞれ用いた。逨結虽解 1 サイクルの所要時間は 2 時間 15 分士 5 分で，1日平均 10 サイクル強で実施した。凍結融解サイクルの自動制御は，制御用供試体の中心部扱入乙た 抵抗温度計㧍よびこれと接続した電子管式自動温度調節計飞よつて行い，測温供試体中心部の温度が所定の温度 を示すようと調節した。各サイクルに和ける供試体中心部の温度は, 測温供試体中心部埋込えで和いた鉄コン スタンタン熱電対によつて自動的飞記録した。図一4・1 は谏結融解 1 サイクルル括ける供試体中心部の温度履歴 を示したものであり，また言一4·5は，涷結融解の任意の 28 サイク ルとついて各サイクルごとに供試体中心部の最高最低温度秄よび所要 時間を示したあのであつて, 本試験装置がきわめて信頼度の高いもの であることがわかる。

な和，供試体を入れる容器には、ゴム製容器を用いた。前記試験方 法試案によれば，試験の全期間を通じて供試体の周囲には，厚さ約 $3 \mathrm{~mm}$ の水末たは氷があるととが必要とされているが，このためには 供試体を網目の寸法 $3.5 \mathrm{~mm}$, 網七モの太さ $3.5 \mathrm{~mm}$ の絧に包んでゴ ム容器に入れ, 供試体と容器壁との間水を注入したのち, 試験槽の 塩化カルシウムブライン中に縌にして入れた。

供試体の凍結融解飞対する抵抗性は, 凍結融解約 30 サイクルごと そその動弹性係数招よび重量を測定し, 試験開始時のそれと比較する ことにより判定した。な扔，同時代供試体の容積も測定したが，供試 体の比重が涷結融解試験中を通じてほぼ一定であるため，その減少の

図-4.1 凍結融解試龭におけ る供試体中心部の温度

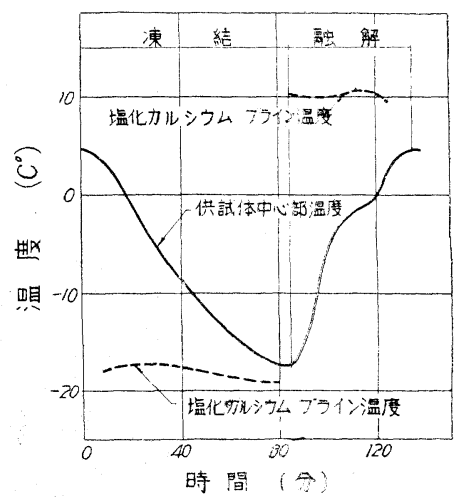

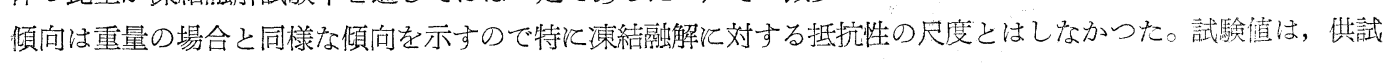
体 2 個の平均値をとつた。

表一4.5 㭿結融解試験における供試体中心部温度および1サイクル所要時間

\begin{tabular}{|c|c|c|c|c|c|c|c|c|c|}
\hline \multirow{2}{*}{ サイクル数 } & 凍 & 結 & 融 & 解 & \multirow{2}{*}{ サイクル数 } & \multicolumn{2}{|c|}{ 凍 結 } & \multicolumn{2}{|l|}{ 融 } \\
\hline & $\begin{array}{c}\text { 最低温度 } \\
\left({ }^{\circ} \mathrm{C}\right)\end{array}$ & $\begin{array}{l}\text { 所要時間 } \\
\text { (分) }\end{array}$ & $\begin{array}{c}\text { 最高温度 } \\
\left({ }^{\circ} \mathrm{C}\right)\end{array}$ & $\begin{array}{l}\text { 所要時間 } \\
\text { (分) }\end{array}$ & & $\begin{array}{c}\text { 最低温度 } \\
\left({ }^{\circ} \mathrm{C}\right)\end{array}$ & $\begin{array}{c}\text { 所要時䦧 } \\
\text { (分) }\end{array}$ & $\begin{array}{c}\text { 最高温度 } \\
\left({ }^{\circ} \mathrm{C}\right)\end{array}$ & $\begin{array}{c}\text { 所要時晶 } \\
\text { (分) }\end{array}$ \\
\hline 1 & -17.2 & 85 & 4.5 & 50 & 17 & -18.0 & 90 & 4.0 & 50 \\
\hline 2 & -17.3 & 85 & 4.5 & 50 & 18 & --18.4 & 85 & 3.6 & 50 \\
\hline 3 & -17.4 & 85 & 4.3 & 50 & 19 & -18.1 & 85 & 4.0 & 50 \\
\hline 4 & -17.7 & 85 & 4.3 & 50 & 20 & -18.0 & 80 & 4.5 & 50 \\
\hline 5 & -17.7 & 80 & 4.5 & 50 & 21 & -18.0 & 85 & 4.4 & 55 \\
\hline 6 & -17.6 & 80 & 4.5 & 50 & 22 & -18.0 & 85 & 4.4 & 50 \\
\hline 7 & -17.8 & 85 & 4.6 & 50 & 23 & -18.2 & 85 & 4.0 & 50 \\
\hline 8 & -17.2 & 85 & 6.0 & 40 & 24 & -18.1 & 85 & 4.0 & 50 \\
\hline 9 & -17.5 & 80 & 5.0 & 50 & 25 & -18.4 & 85 & 4.7 & 50 \\
\hline 10 & -17.2 & 85 & 4.8 & 55 & 26 & -18.4 & 90 & 4.0 & 50 \\
\hline 11 & -17.5 & 80 & 5.0 & 50 & 27 & -18.0 & 85 & 5.8 & 50 \\
\hline 12 & -17.3 & 85 & 5.0 & 55 & 28 & -18.0 & 85 & 4.6 & 50 \\
\hline 13 & -17.7 & 85 & 4.8 & 50 & & & & 47 & \\
\hline 14 & -18.0 & 85 & 4.5 & 50 & 半均倠 & 18. & & 4. & \\
\hline 15 & -17.8 & 90 & 4.5 & 50 & 標準偏差 & 0.4 & & 0.5 & \\
\hline 16 & -18.0 & 85 & 4.6 & 50 & & & & & \\
\hline
\end{tabular}


6. 断熱温度上昇試験方法 コンクリートの硬化熱による温度上冢は，断熱熱量計を用いて測定した。試験に 用いた断熱熱量計は，従来から用いられていたものと同じ種類のものである。

すなわち，試験槽内はコルク隔壁によつて，コンクリート供試体を入れる内槽とこれをとりまく外槽(空気槽) の 2 つ分けられて招り，いかなる温度と扔いても内槽温度と外槽温度をたえず等しく保つことによつて供試体 を原則的に断熱状態汸くことができるようとなつている。この作用は，コルク隔壁内に埋込まれている熱電対 招よびこれ接続された自動温度調節計の働きによつて行われる。元来試験装置は完全に断熱的なものでないの で，試験槽内より槽外にある程度の熱量が漏洩することはさけられず，従つて内槽温度と外槽温度を等しく保つ ためには，外槽に対して漏洩熱量汇相当する熱量だけ補わなければならない。この漏洩熱量はある温度の範围内 では試験槽内温度と槽外温度との差飞ほぼ比例すると考光られるので, 試験槽外温度を一定に保つ場合には, 漏 洩熱量すなわち補正熱量は試験槽内温度（またはコンクリート温度）のみの関数で与兄られる。この種の断熱熱 量計を用いる場合には，その試験慒は恒温室に招き，試験にさきだちあらかじめ試験槽内温度と補正熱量との関 係を求めて预き，実際の試験江当るのが通常である。

試験に用いた恒温室は縦 $1.9 \mathrm{~m}$, 横 $2.6 \mathrm{~m}$, 高さ $2.2 \mathrm{~m}$ の木製キャビネットで, 周囲の 4 面および上下面の壁 厚は $10 \mathrm{~cm}$ とし，その中には保温材として扔がくずを十分填充したものである。室内の温度調節は加熱用とし て $100 \mathrm{~W}$ 電球 3 個, $60 \mathrm{~W}$ 電球工個を用い，それらを必要沁じて人為的飞随時点滅すること飞より恒温江調 節した。

厳冬時に和いても，100 W 電球 3 個程度で容易飞 $20 \pm 2^{\circ} \mathrm{C}$ 飞室温を保つことができた。な和断熱試験中に招 ける恒温室の温度は， $20 \pm 2^{\circ} \mathrm{C}$ を原則としたが，コンクリートの打込み温度が相違する場合には, 適宜恒温室 の温度を変え，試験の実施支障のないようにした。

試験の実施当つては, 供試コンクリートを直徍 $28 \mathrm{~cm}$, 高さ $25 \mathrm{~cm}$ のブりキ製容器飞入れ, ふたをハンダづ けによつて密封したのちただちに断熱熱量計に入れ，材令 7 日までその上旱温度を測定した。コンクリートの温 度測定は供試体中心部に捙入した抵抗温度計により，自動的にとの温度を記録していった。前述のハンダづけ操 作による加熱のために，コンクリート温度は打込み時にくらべて多少上景したが，フライ アッシュを用いたコ ンクリートと用いないコンクリートとを比較する目的に対しては別に支障はないと考劣られる。断熱試験は材令 7 日柰でしか行わなかつたが，乙れは断熱熱量計が一式しかなかつたために，材令 28 日末で継続すると1シリ 一ズの試験を終克るのとは少なくとも4カ月を要することおよび，そのような長期間飞わたつてコンクリート材 料，その他試験の諸条件を一定保つことがまづ不可能近いことなどを考慮したためである。

7. 乾燥収縮試験方法 試験飞当つてはコンクリートの材料を全部計量し, 温度 $20^{\circ} \mathrm{C}$, 相対湿度 $80 \%$ の恒温 室に入れて和き，コンクリートの練り上り温度が $20^{\circ} \mathrm{C}$ となるようにした。コンクリートの練り混ぜは，KK 式 1切のミキサを用いて用い，スランプが $5 \mathrm{~cm}$ のコンクリートを $25 \mathrm{~mm}$ の板フルイで $25 \mathrm{~mm}$ 以上の骨材を取 除いた。また供試体は，標識とするオパール ガラスを測定の有効長さが $34 \mathrm{~cm}$ そなるようとセットした $10 \times 10$ $\times 40 \mathrm{~cm}$ 角柱型ワクで成形し，これそふたをして 2 日間恒温室飞とのまま持いたのち，型りクから取り外し， $20^{\circ} \mathrm{C}$ の水中養生を 5 日間行つた。次飞供試体は温度 $20^{\circ} \mathrm{C}$, 岸酸カリの飽和溶液で相対湿度 $45 \%$ 飞調節される $54 \times 44 \times 37 \mathrm{~cm}$ の乾燥箱の中に 3 本づつ入れて乾燥町蔵した。供試体の乾燥飞よる収縮は， 7 ・14・28・50日

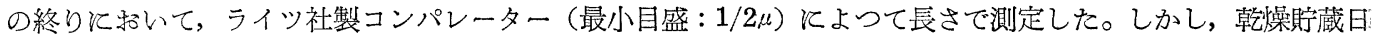
数 7 日・14 日括いては，乾煤箱の炭酸カリ飽和溶液が，相対湿度を $45 \%$ 飞調節する能力よりも，供試体から 蒸発する水分の影響が大きく，安定した結果が得られなかつた。

さらK, JIS R5201 (セメントの物理試験方法) そ準じてモルタル供試体 (溷定の有効長さ：14 cm)を成形し, コンクリートの場合と同様に $23 \times 19 \times 12 \mathrm{~cm}$ の乾燥箱の中に 3 本づつ入れて貯蔵し， $3 \cdot 7 \cdot 14 \cdot 28 \cdot 50$ 日

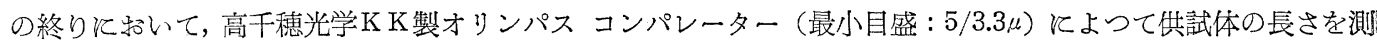
つた。この場合も，乾燥貯蔵日数 3 日・7日拈いては, 乾煤箱の相対湿度が $45 \%$ 亿調節されていなかつたこ とが測定の結果に現われたように認められる。

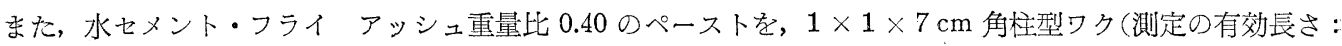

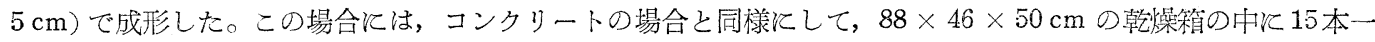
緒に入れて乾爆唄蔵し，3・7・14・28・50日の終りと扮いて，供試体の長さをライツ社製コンパレーター（最 小目盛: $5 / 3 \mu)$ 飞つて測定した。この場合は, 供試体から蒸発する水分に対して, 乾燥箱の容積が大きく, 岸 酸カリの飽和溶液が相対湿度を $45 \%$ 飞調節する能力が十分であつたため, 安定して測定結果が得られた。

〔2〕フライ アッシュがまだ固まらないコンクリートの性質におよぼす影響 
良質の尼ケ崎フライ アッシュでセメントの一部を招きか壳てコンクリートを造る場合, 所定のコンシステン シーをうるために必要な単位水量は, フライアッシュを用いない場合よりも減少する。この単位水量の減少程 度は，フライ アッシュの品質・フライ アッシュのオキカエ率・コンクリートの配合・砂の粒度・セメントの種 類などによつて相違する。以下にこれらの試験結果を列記する。

1. コンクリートのコンシステンシーに拉よぼす影響 13 種のフライ アッシュ掠よび小野田普通ポルトラン ド セメントを用い,フライ アッシュオキカエ率を $20 \%$ として

(i) 粗骨材の最大寸法 $25 \mathrm{~mm}$ ，単位セメント・フライ アッシュ量 $306 \mathrm{~kg} / \mathrm{m}^{3}$ ， スランプ約 $6 \mathrm{~cm}$ のコンク 3) 一下 (実験 : 001)

(ii) 粗骨材の最大寸法 $30 \mathrm{~mm}$, 単位セメント・フライ アッシュ量 $285 \mathrm{~kg} / \mathrm{m}^{3}$, スランプ約 $6 \mathrm{~cm}$, 空気量 約 5\% のコンクリート(実験 : 002)

(iii） 粗骨材の最大寸法 $30 \mathrm{~mm}$, 単位セメント・フライ アッシュ量 $280 \mathrm{~kg} / \mathrm{m}^{3}$, スランプ約 $7 \mathrm{~cm}$, 案気量 約 5\% のコンクリート（実験：003）

(iv) 粗骨材の最大寸法 $30 \mathrm{~mm}$, 単位セメント・フライ アッシュ量 $280 \mathrm{~kg} / \mathrm{m}^{3}$ ， スランプ約 $5.5 \mathrm{~cm}$, 空気量

表一4・6 品質の相違するフライ アッシュを用いたコンクリートの配合

\begin{tabular}{|c|c|c|c|c|c|c|c|c|c|c|c|c|c|}
\hline \multirow{2}{*}{$\begin{array}{l}\text { 実験整 } \\
\text { 理番号 }\end{array}$} & \multicolumn{3}{|c|}{ フライ アッシュ } & \multirow{2}{*}{$\begin{array}{l}\text { 粗骨材 } \\
\text { の最大 } \\
\text { 寸法 } \\
(\mathrm{mm}) \\
\end{array}$} & \multirow{2}{*}{ 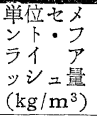 } & \multirow{2}{*}{ 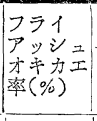 } & \multicolumn{2}{|c|}{ 単位水量 } & \multirow{2}{*}{$\begin{array}{l}\text { 粗細骨 } \\
\text { 禁重量 } \\
\text { 比 }\end{array}$} & \multirow{2}{*}{ 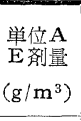 } & \multirow{2}{*}{$\begin{array}{l}\text { スラン } \\
\text { プ } \\
(\mathrm{cm})\end{array}$} & \multirow[b]{2}{*}{$\begin{array}{l}\text { 空文量 } \\
(\%)\end{array}$} & \multirow{2}{*}{ 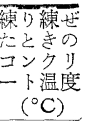 } \\
\hline & 名 称 & $\begin{array}{c}\text { 強熱隇量 } \\
(\%)\end{array}$ & 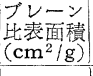 & & & & $\mathrm{kg} / \mathrm{m}^{3}$ & 比 & & & & & \\
\hline \multirow{6}{*}{001} & - & - & -- & \multirow{6}{*}{25} & \multirow{6}{*}{306} & 0 & 190 & 1.00 & \multirow{6}{*}{1.12} & \multirow{6}{*}{0} & 6 & \multirow{6}{*}{-} & \multirow{6}{*}{26} \\
\hline & A & 1.6 & 3680 & & & 20 & 181 & 0.95 & & & 6 & & \\
\hline & B & 2.4 & 3270 & & & $"$ & 183 & 0.96 & & & 6 & & \\
\hline & D & 2.0 & 2660 & & & " & 183 & 0.96 & & & 6 & & \\
\hline & $\mathrm{E}$ & 2.6 & 3110 & & & " & 188 & 0.99 & & & 6.5 & & \\
\hline & $\mathrm{H}$ & 1.9 & 2410 & & & " & 186 & 0.98 & & & 6 & & \\
\hline \multirow{8}{*}{002} & - & - & - & \multirow{8}{*}{30} & \multirow{8}{*}{285} & 0 & 150 & 1.00 & \multirow{8}{*}{1.6} & 23 & 6.5 & 5.1 & \multirow{8}{*}{11} \\
\hline & $\check{\mathrm{B}}$ & 2.4 & 3270 & & & 20 & 143 & 0.95 & & 50 & 6.5 & 5.4 & \\
\hline & C & 3.0 & 3240 & & & " & 143 & 0.95 & & 78 & 6.5 & 5.6 & \\
\hline & D & $2.0^{\circ}$ & 2660 & & & " & 143 & 0.95 & & 40 & 5 & 4.9 & \\
\hline & $\mathrm{E}$ & 2.6 & 3110 & & & $"$ & 144 & 0.96 & & 120 & 7 & 5.5 & \\
\hline & $\mathrm{K}$ & 1.5 & 3180 & & & $"$ & 141 & 0.94 & & 48 & 6 & 5.2 & \\
\hline & L & 1.3 & 2810 & & & " & 141 & 0.94 & & 26 & 6 & 5.0 & \\
\hline & $\mathbf{M}$ & 1.4 & 3290 & & & " & 141 & 0.94 & & 42 & 6 & 5.1 & \\
\hline \multirow{9}{*}{003} & - & - & - & \multirow{9}{*}{30} & \multirow{9}{*}{280} & 0 & 152 & 1.00 & \multirow{9}{*}{1.68} & 21 & 8 & 5.0 & \\
\hline & B & 2.4 & 3270 & & & 20 & 143 & 0.94 & & 49 & 7 & 5.0 & \\
\hline & C & 3.0 & 3243 & & & " & 143 & 0.94 & & 78 & 5.5 & 5.1 & \\
\hline & $F$ & 1.9 & 2760 & & & " & 146 & 0.96 & & 68 & 7.5 & 5.0 & \\
\hline & $\mathrm{K}$ & 1.5 & 3180 & & & $"$ & 143 & 0.94 & & 48 & 7 & 4.9 & 8 \\
\hline & L & 1.3 & 2810 & & & " & 143 & 0.94 & & 28 & 7 & 5.2 & \\
\hline & $\mathbf{M}$ & 1.4 & 3290 & & & " & 143 & 0.94 & & 37 & 7 & 5.1 & \\
\hline & $\mathrm{N}$ & 0.9 & 3460 & & & " & 140 & 0.93 & & 65 & 7 & 4.7 & \\
\hline & $\mathrm{O}$ & 2.4 & 2940 & & & $"$ & 146 & 0.96 & & 36 & 7 & 5.5 & \\
\hline & - & - & - & & & 0 & 150 & 1.00 & & 6.5 & 5.5 & 5.1 & \\
\hline & B & 2.4 & 3270 & & & 20 & 142 & 0.95 & & 23 & 5 & 4.9 & \\
\hline 004 & C & 3.0 & 3240 & 30 & 280 & " & 144 & 0.96 & 16 & 38 & 5 & 4.8 & 20 \\
\hline & L & 1.3 & 2810 & & & $"$ & 143 & 0.95 & 1.0 & 8.8 & 6 & 5.1 & 20 \\
\hline & $\mathrm{M}$ & 1.4 & 3290 & & & $"$ & 143 & 0.95 & & 15 & 5.5 & 5.1 & \\
\hline & $\mathrm{Q}$ & 0.7 & 3620 & & & " & 140 & 0.93 & & 8.5 & 5 & 4.9 & \\
\hline
\end{tabular}

備考 AE剂は実験:002，003においてはピンソルレヂンを用い，実験:004においてはドレンネートXを用いた。 
約 5\%のコンクリート（実験：004）

を造をるため配合を定めた結果は 表一4.6 のと扮りである。

すなわちとの試験結果より次のことが認められる。

（1）これらの試験用いた程度の品質のフライ アッシュ（強熱減量：0.7 3.0\%，ブレーン比表面積: $2400 〜$ $\left.3700 \mathrm{~cm}^{2} / \mathrm{g}\right)$ でセメントの $20 \%$ を怙きかえてコンクリートを造る場合, 所定のスランプをうるために必要な単 位水量は，用いるフライ アッシュの品質飞よつて多少の差はあつても，すべて，フライ アッシュを用いない場 合よりも減少して扬り，その減少範囲は 1〜7\% となつている。おた，同一フライアッシュでも実験飞よつて。 その単位水量の比は相違しているが，これは，それらの実験をそれぞれある程度の期間を敌いて行つたからであ る。

（2）フライ アッシュを用いた場合のコンクリートの単位水量の減少程度は，一般とフライ アッシュの粉末度

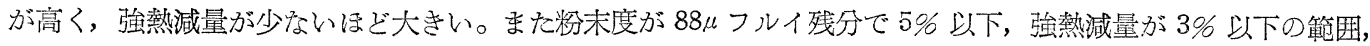
すなわち良質のフライ アッシュでは，奉用的にはすべてほぼ同等とみなすととができる。图-4.2 敊よで図一 4.3 は 表一4.6 飞もとずいてフライ アッシュを用いたコンクリートの基準配合飞対する単位水量減少百分率々 フライアッシュの粉末度挌よび強熱減量との関係の一例を示したものである。

図一4:2 フライアッシュの $8 B \mu$ フルイ残分 とコンクリートの単位水量との関係

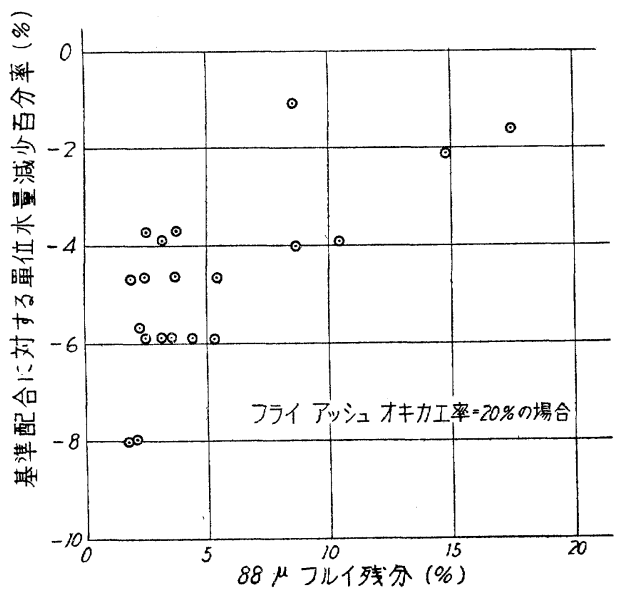

図一4・3 フライ アッシュの強熱減量亡 コンクリートの単位水量との関係

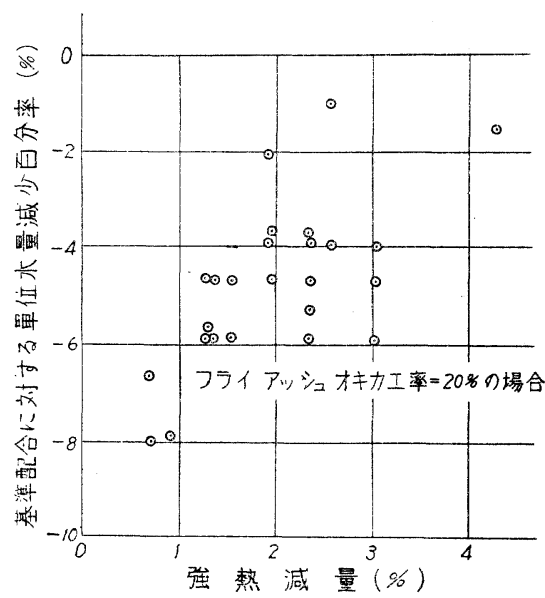

（3）フライアッシュをコンクリートに用いた場合の単位水量の減少程度は，AE 剤を用いても用いなくても ほぼ同じである。また用いる $\mathrm{AE}$ 绪が相違しても変らない。

2. フライアッシュオキカエ率括よびコンクリートの配合と単位水量との関係

（i） 小野田普通ポルトランド セメント捛よびフライ アッシュAを用い，粗骨材の最大寸法 $30 \mathrm{~mm}$ ，フライ アッシュオキカエ率を $0 \cdot 10 \cdot 20 \cdot 30 \cdot 50 \%$ としたコンクリート（実験：011）

$$
\text { 単位セメント・フライアッシュ量 }
$$

$\begin{array}{ll}\text { a. } & 239 \mathrm{~kg} / \mathrm{m}^{3} \\ \text { b. } & 285 \prime \prime \\ \text { c. } & 354 \prime \prime\end{array}$

$$
\begin{gathered}
\text { スランプ } \\
2 \mathrm{~cm} \\
4 " \\
6.5 ”
\end{gathered}
$$

(ii) アサノ マスコンセメント拈よびフライ アッシュ Q ト・フライ アッシュ量 $180 \mathrm{~kg} / \mathrm{m}^{3}$, フライ アッシュ オキカエ率 $0 \cdot 20 ・ 30 \cdot 40 \%$, スランプ $4 \mathrm{~cm}$, 空気量 4 \%としたダム用コンクリート（実験：101）

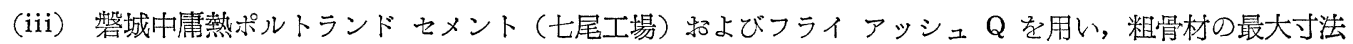
$80 \mathrm{~mm}$, 単位セメント・フライ アッシュ量 $180 \mathrm{~kg} / \mathrm{m}^{3}$, フライ アッシュオキカエ率 $0 ・ 20 ・ 30 ・ 40 \%$, スラ ンプ $3 \mathrm{~cm}$, 空気量 $4 \%$ としたダム用コンクリート (実験 : 102)

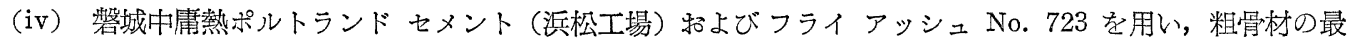
大寸法 $150 \mathrm{~mm}$, 単位セメント・フライ アッシュ量 $140 \mathrm{~kg} / \mathrm{m}^{3}$, フライ アッシュオキカエ率 $0 \cdot 20 ・ 30 ・ 40 \%$, 
スランプ $4.5 \mathrm{~cm}$, 空気量 $4 \%$ としたダム用コンクリート（実験 : 104)

を造るために定めた配合は 表一 $4 \cdot 7$ 亿示すと物りである。

表一4・7 フライ アッシュ オキカエ率を変えたフライ アッシュを用いたコンクリートの配合

\begin{tabular}{|c|c|c|c|c|c|c|c|c|c|c|c|c|c|}
\hline $\begin{array}{l}\text { 实験整 } \\
\text { 理番号 }\end{array}$ & $\begin{array}{l}\text { フライ } \\
\text { アッジ }\end{array}$ & セメント & 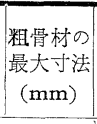 & 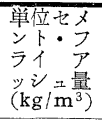 & $\begin{array}{l}\text { フライ } \\
\text { ア兴シ } \\
\text { オカュ } \\
\text { 率 }(\%)\end{array}$ & $\frac{\text { 単 位 }}{\mathrm{kg} / \mathrm{m}^{3}}$ & $\frac{\text { 水量 }}{\text { 比 }}$ & $\mid \begin{array}{l}\text { 粗細骨材 } \\
\text { 重 量 比 }\end{array}$ & $\begin{array}{l}\text { 単位 } \mathrm{AE} \\
\text { 剂量 } \\
\left(\mathrm{g} / \mathrm{m}^{3}\right)\end{array}$ & $\left|\begin{array}{c}\text { スランプ } \\
(\mathrm{cm})\end{array}\right|$ & $\begin{array}{l}\text { リモル } \\
\text { シンゲ } \\
\text { (回) }\end{array}$ & $\begin{array}{c}\text { 空気量 } \\
(\%)\end{array}$ & $\begin{array}{c}\text { 練り混ぜ } \\
\text { たときの } \\
\text { ચンクリ } \\
\text {-ト温度 } \\
\left({ }^{\circ} \mathrm{C}\right)\end{array}$ \\
\hline & & & & 239 & $\begin{array}{r}0 \\
10 \\
20 \\
30 \\
50\end{array}$ & $\begin{array}{l}177 \\
172 \\
169 \\
165 \\
155\end{array}$ & $\begin{array}{l}1.00 \\
0.97 \\
0.95 \\
0.93 \\
0.87\end{array}$ & 1.20 & 0 & $\begin{array}{l}2 \\
2 \\
2.5 \\
2.5 \\
2\end{array}$ & - & - & 25 \\
\hline 011 & A & $\begin{array}{l}\text { 小野田 } \\
\text { 普道术 } \\
\text { ルトラ } \\
\text { ンド } \\
\text { 它メン } \\
\text { 卜(津 } \\
\text { 久見工 } \\
\text { 場製) }\end{array}$ & 30 & 285 & $\begin{array}{r}0 \\
10 \\
20 \\
30 \\
50\end{array}$ & $\begin{array}{r}177 \\
172 \\
169 \\
165 \\
155\end{array}$ & $\begin{array}{l}1.00 \\
0.97 \\
0.95 \\
0.93 \\
0.87\end{array}$ & 1.30 & 0 & $\begin{array}{l}4 \\
4 \\
4.5 \\
4.5 \\
4\end{array}$ & - & - & 25 \\
\hline & & & & 354 & $\begin{array}{r}0 \\
10 \\
20 \\
30 \\
50\end{array}$ & $\begin{array}{l}177 \\
172 \\
169 \\
165 \\
155\end{array}$ & $\begin{array}{l}1.00 \\
0.97 \\
0.95 \\
0.93 \\
0.87\end{array}$ & 1.40 & 0 & $\begin{array}{l}6.5 \\
6.5 \\
7 \\
7 \\
5\end{array}$ & - & - & 27 \\
\hline 101 & Q & 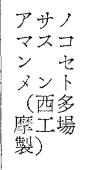 & 80 & 180 & $\begin{array}{r}0 \\
20 \\
30 \\
40\end{array}$ & $\begin{array}{l}117 \\
111 \\
109 \\
106\end{array}$ & $\begin{array}{l}1.00 \\
0.95 \\
0.93 \\
0.91\end{array}$ & 2.50 & $\begin{array}{l}3.5 \\
4.4 \\
4.8 \\
5.4\end{array}$ & $\begin{array}{l}4 \\
4 \\
4 \\
4\end{array}$ & - & $\begin{array}{l}4.1 \\
4.1 \\
4.1 \\
4.0\end{array}$ & 21 \\
\hline 102 & Q & 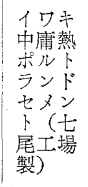 & 80 & 180 & $\begin{array}{r}0 \\
20 \\
30 \\
40\end{array}$ & $\begin{array}{l}118 \\
112 \\
110 \\
108\end{array}$ & $\begin{array}{l}1.00 \\
0.95 \\
0.93 \\
0.91\end{array}$ & 2.45 & $\begin{array}{l}5 \\
6 \\
6.5 \\
7\end{array}$ & $\begin{array}{l}3.2 \\
2.8 \\
3 \\
3.5\end{array}$ & - & $\begin{array}{l}4.0 \\
4.1 \\
4.0 \\
4.0\end{array}$ & 17 \\
\hline 104 & No.723 & 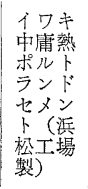 & 150 & 140 & $\begin{array}{r}0 \\
20 \\
30 \\
40\end{array}$ & $\begin{array}{l}92 \\
87 \\
86 \\
85\end{array}$ & $\begin{array}{l}1.00 \\
0.95 \\
0.94 \\
0.92\end{array}$ & 3.40 & $\begin{array}{r}4 \\
17 \\
26 \\
32\end{array}$ & $\begin{array}{l}4.1 \\
4.3 \\
4.5 \\
4.9\end{array}$ & $\begin{array}{l}36 \\
44 \\
43 \\
44\end{array}$ & $\begin{array}{l}4.0 \\
3.9 \\
4.1 \\
4.1\end{array}$ & 9 \\
\hline
\end{tabular}

備 考 AE剂はドレンネートXを用いた。

この表から次のことが認められる。

(1) 良質のフライ アッシュを用いたコンクリートの単位水量の減少程度は,フライ アッシュオキカエ率が増

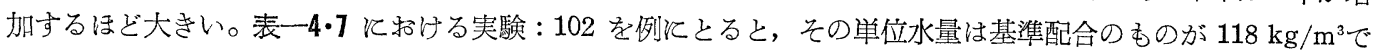
あるのに対し,フライ アッシュオキカエ率 $20 \%$ では $112 \mathrm{~kg} / \mathrm{m}^{3}$, オキカエ率 $40 \%$ では $108 \mathrm{~kg} / \mathrm{m}^{3}$ となつて いて，それ華れ5\% 特よび $9 \%$ だけ減少している。

（2）実験：011 は,フライアッシュを用いたコンクリートの単位水量の減少程度を, 特箪位セメント・フラ イアッシュ量の相違したコンクリートについて比較した一例であつて, 単位セメント・フライ アッシュ量が, $239 \mathrm{~kg} / \mathrm{m}^{3}$ および $354 \mathrm{~kg} / \mathrm{m}^{3}$ のいずれの場合もほぼ同程度であつた。ただ単位セメント・フライアッシュ量 が $354 \mathrm{~kg} / \mathrm{m}^{3}$ の場合に, フライアッシュオキカ土率が $50 \%$ 飞もなると“セメント+フライアッシュ”の絶 対容積がいらじるしく増加するため(この絶対容積汇相当するセメント量汇換算すると約 $440 \mathrm{~kg}$ となる)練り上 りコンクリートは非常に粘つこく, ひつつきやすい状態となる。これらのことを要約すると通常のコンリトート 工事に用いられる程度の学位セメント量の籍囲では, フライアッシュを用いた場合に括ける単位水量の減少程 
度は，配合の貧富に関せずほぼ同程度とみられる。

（3）表一4・7 の各実験は用いたコンクリートの材料も全く相違するものであり，季たそれぞれ相当期間を招い て行つたあのであるが，これらの実験結果からセメントの種類による単位水量の減少程度は，ほぼ同じであると いうことができる。

3. 砂の粒度がフライアッシュを用いたコンクリートの単位水量と秥よぼす影響 小野田普通ポルトランド セメント特よびフライアッシュ $\mathrm{Q}$ を用い，粗粒率が $2.44 ・ 2.76 ・ 3.33$ の種の砂てついて，それぞ视粗骨材の 最大寸法を $30 \mathrm{~mm}$ ，単位セメント・フライ アッシュ量を $280 \mathrm{~kg} / \mathrm{m}^{3}$ ，フライアッシュオキカエ率を 0 ・ 20 ・ 30 \%，スランプを $6 \mathrm{~cm}$ としたコンクリート喜造るための配合を定めた結果は 表一4.8 のと括りである。

表一4・8 砂の粒度が相違する場合のフライ アッシュを用いたコンクリートの配合の一例

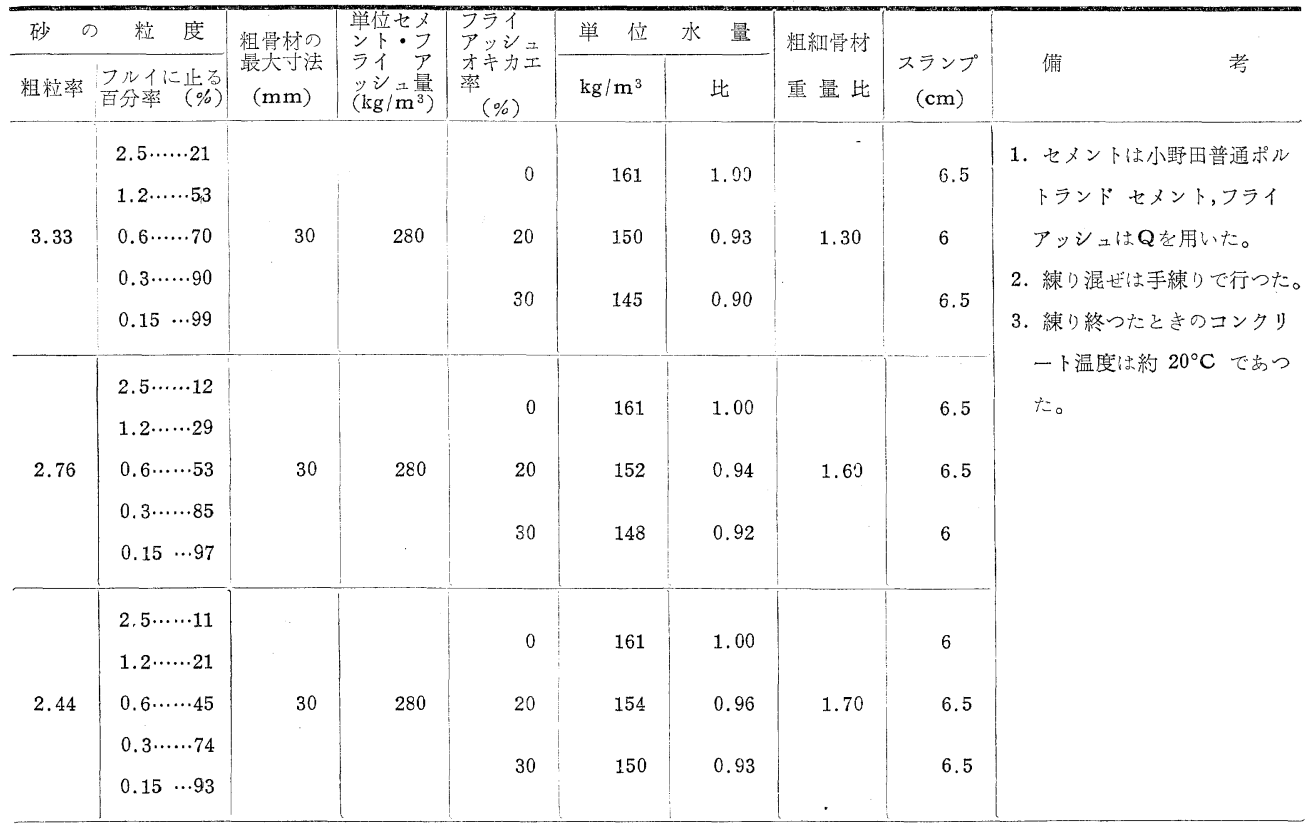

表から次のことが認められる。すなわち，フライ アッシュを用いたコンクリートの単位水量の減少程度は， 以上飞述べた諸因子のほが，用いる秒の粒度によつても相違し，一般に粗い杪を用いる場合ほど大きい。表一 $4 \cdot 8$ Kよれば, フライ アッシュオキカエ率 $30 \%$ の場合の基準配合に対する単位水量比は, 粗粒率が $2.44 \cdot 2.76$ ・3.33 の秒に対しそれぞれ $0.93 \cdot 0.92 \cdot 0.90$ となつていて，単位水量の減少程度は粗粒率が大きいほど大きい。

4. フライアッシュの所要水量比とフライアッシュを用いたコンクリートの単位水量との関係 III [7]で述 ベたように, フライ アッシュの品質判定の一方法としての所要水量と試験飞よるフライアッシュの所要水量比 は試験炕用いるモルタルの配合によつて相違する。い定のコンシステンシーをうるのに必要な水量を, モル タルの場合とコンクリートの場合とについて相関関係があることが考兄られるので，その相対値を用いて調べて みよう。

表一-13・游けるa配合を用いた場合のフライ アッシュの所要水 量比と, 表一4·6亿招けるフライアッシュを用いたコンクリートの基

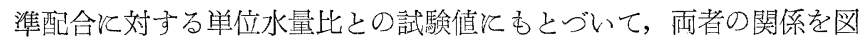
示すれば, 図一4.4のと扮りであつて, 両者の間にはほ活線関係が 認められる。乙かしその絶対值は，フライアッシュの所要水量比が 96〜106\%であるのに対し，フライアッシュを用いたコンクリートの 単位水量比は，93〜99\%であつて，両者の間飞相相当開きがあり，ま たフライアッシュの所要水量比が $100 \%$ 以上のものでも, コンクり 一トの単位水量比は，すべて $100 \%$ 以下になつている。このことはフ ライアッシュの所要水量比試験方法として，表一.3・13 亿特汀る a 配 合を用いる方法汇よる場合，所要水量比の規格值を100\% 以下にする

図一4.4 フライ アッシュの所 要水量比とフライ アッシュ コンクリート（オキカエ率 20 \%) の単位水量比との関係

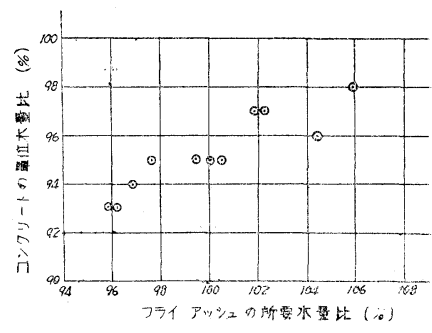


必要がないととを示すものである。

5. $\mathrm{AE}$ コンクリートの単位 $\mathrm{AE}$ 剂量飞执よぼす影響

(1) フライアッシュの強熱減量扮よび吸着性と単位 $\mathrm{AE}$ 用量との関係：フライ アッシュでセメントの一部を おきかえて AE コンクリートを造る場合, 所定の空気量をうるために必要な笚位 $\mathrm{AE}$ 剤量は 表一4.9 のように フライ アッシュの品質によつて相違し，一般にフライ アッシュを用いない場合よりも増加する。

表一4.9 フライ アッシュの強熱減量および吸着性と単位 $\mathrm{AE}$ 剂量

\begin{tabular}{|c|c|c|c|c|}
\hline 実験整理番号 & フライ アッンニ & $\begin{array}{c}\text { 強 } \\
(\%)\end{array}$ & 吸 $\underset{(\mathrm{mg} / \mathrm{g})}{\text { 着 }}$ 量 & 単位 $\underset{\left(\mathrm{g} / \mathrm{m}^{3}\right)}{A \mathrm{~A})}$ 剂量 \\
\hline \multirow{8}{*}{002} & な 2 & $\rightarrow$ & - & 23 \\
\hline & B & 2.4 & 0.55 & 50 \\
\hline & c & 3.0 & 0.65 & 78 \\
\hline & D & 2.0 & 0.45 & 40 \\
\hline & $\mathrm{E}$ & 2.6 & 0.80 & 120 \\
\hline & K & 1.5 & 0.55 & 48 \\
\hline & L & 1.3 & 0.40 & 26 \\
\hline & M & 1.4 & - & 42 \\
\hline \multirow{9}{*}{003} & な & - & - & 21 \\
\hline & B & 2.4 & 0.55 & 49 \\
\hline & C & 3.0 & 0.65 & 78 \\
\hline & F & 1.9 & 0.65 & 68 \\
\hline & $\mathrm{K}$ & 1.5 & 0.55 & 48 \\
\hline & L & 1.3 & 0.40 & 28 \\
\hline & M & 1.4 & - & 37 \\
\hline & $N$ & 0.9 & 0.60 & 65 \\
\hline & o & 2.4 & 0.45 & 36 \\
\hline 搹 & \multicolumn{4}{|c|}{ 表 $3.1 ； 3.11 ４ .6$ 参照 } \\
\hline
\end{tabular}

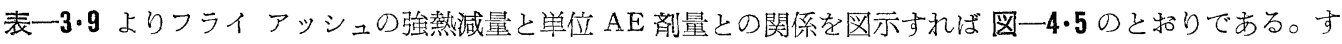
なわち，品質の異なるフライ アッシュを用いた場合の単位 $\mathrm{AE}$ 剤量（ビンソル レジン）とフライ アッシュの 強熱減量との間には一定の関係を見出すことができない。

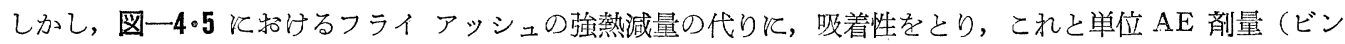
ソルレジン)との関係を求めれば，図一4・6のようになり，両者の間にはほぼ一定の関係が認められる。また 剤として，ドレシネートXを用いた場合飞す，これと全く同一の傾向が認められる。このととはフライアッシュ

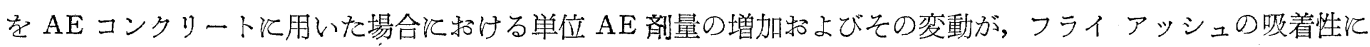
よつて支配されていることを示すものと考光られる。

(2) フライアッシュのオキカ 工率と単位 $\mathrm{AE}$ 剠量との関係 : ド レシネートXを用い, 表一4.7の 配合によつて行つた試験の結果は 図一4・7のと括りである。すなわち フライアッシュでポルトランド セメントの一部を呿きかえて $\mathrm{AE}$ コンクリートを造る場合, 所定の 空気量をうるために必要な単位 $\mathrm{AE}$ 剤量は, フライアッシュオ キカエ率吣じて直線的偪加す る。またオキカエ率の増加ととも なう単位 AE 剂量の増加割合は,
図一4・5 フライ アッシュの強熱 減量亡単位 $\mathrm{AE}$ 剂量之の関係

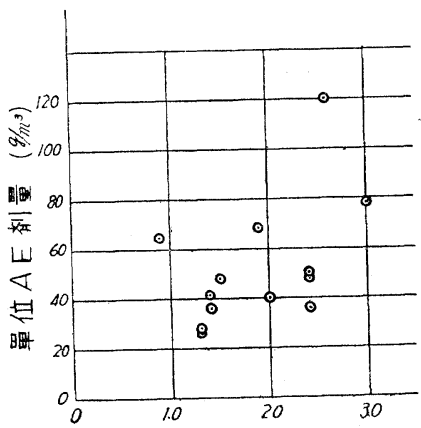

強熱減量 $(\%)$
図-4·6 フライ アッシュの吸着 性亡单位 $\mathbf{A E}$ 剂量亡の関係

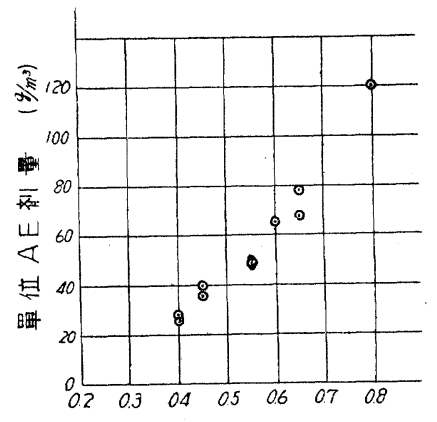

吸着量 ( m/g/s) 
一般にフライアッシュの吸着性の大小左右される。

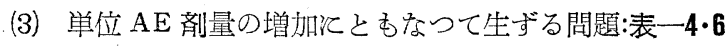
の実験例では，セメントの $20 \%$ をフライ アッシュで招きか えて造つた $\mathrm{AE}$ コンクリートの単位 $\mathrm{AE}$ 郕量が,フライアッ シュを用いない場合の 1.1 5.2 倍になつている。またフライ アッシュを用いたコンクリートの単位 AE郕量は, フライ ア ッシュオキカエ率が増加するほど増加することを考光ると， 場合飞よつてはフライ アッシュを用いない場合の約 10 倍と なりうることもありうる。この場合 $\mathrm{AE}$ 荗それ自体が，コン クリートの性質に䄮よぼす悪影響の有無が問題となる。AS $\mathrm{TM}: \mathrm{C} 350-54 \mathrm{~T} \cdot$ のライ アッシュ規格試案では, フライ アッシュでセメントの $20 \%$ を拎きか克て所定の AE コンク リートを造つた場合の単位 $\mathrm{AE}$ 郕量が, フライ アッシュを 用いない場合の 2 倍をこえないことを要求している。

乙かしこれは，ある種の市販 $\mathrm{AE}$ 剤のうちと含まれている 分散材, 硬化促進材もしくは緩結材がコンクリートの品質飞 拉よぼす雳影響を考慮して定めたものであつて,フライアッ シュを用いた場合の単位 $\mathrm{AE}$ 成量が，2 倍をこえる場合であ つて委，そのコンクリート飞ついて所定の試験を行つて満足な結果が得られた場合，または用いる AE剤がすで 侙験されたものであり，かついま用いようとするフライアッシュよりも多量のAE郕を必要とするフライア ッシュについて経験上満足な結果が確誌されている場合には，2倍ということにこだわらなくてもよいととを同 試案ではうたつている。現在までと行つた実験の範囲内では，ビンソルレジン拉よびドレシネートXについて は，これを相当量用いてもなんら悪影響淰められない。

6. フライアッシュがコンクリートのブリージングと和よぼす影響 フライ アッシュがコンクリートのブリ ージングそ拈よぼす影響を雄かめるため, 富配合コンクリート（骨材最大寸法 $30 \mathrm{~mm}$, 単位セメント・フライア ッシュ量 $280 \mathrm{~kg} / \mathrm{m}^{3}$ ) 执よび賀配合コンクリート（粗骨材最大寸法 $120 \mathrm{~mm}$, 単位セメント・フライ アッシュ 量 $180 \mathrm{~kg} / \mathrm{m}^{3}$ ) そついて，ASTM C232-52T そ準じて試験を行つた。試験飞用いたコンクリートの配合および試

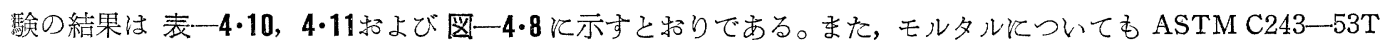

表—4・10 コンクリートのブリージング試験に用いた配合

\begin{tabular}{|c|c|c|c|c|c|c|c|c|c|}
\hline $\begin{array}{c}\text { 粗骨材最 } \\
\text { 大寸法 } \\
(\mathrm{mm})\end{array}$ & 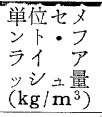 & $\begin{array}{c}\text { フライ } \\
\text { ア⿳亠口冋. } \\
\text { 才キカ工 } \\
\text { 率 } \\
(\%)\end{array}$ & $\begin{array}{l}\text { 単 位 } \\
\text { 水 量 } \\
\left(\mathrm{kg} / \mathrm{m}^{3}\right)\end{array}$ & $\begin{array}{c}\text { 砂 } \\
\text { 百分率 } \\
(\%)\end{array}$ & $\begin{array}{l}\text { 単位 } \mathrm{AE} \\
\text { 剂 量 } \\
\left(\mathrm{g} / \mathrm{m}^{3}\right)\end{array}$ & $\begin{array}{c}\text { スランプ } \\
(\mathrm{cm})\end{array}$ & $\begin{array}{c}\text { 空気量 } \\
(\%)\end{array}$ & $\begin{array}{l}\text { 練り上り } \\
コ ン ク リ \\
\text { コトの温 } \\
\text { 度 } \\
\left({ }^{\circ} \mathrm{C}\right)\end{array}$ & 備 \\
\hline 30 & 280 & 0 & 137 & 37.0 & 2.1 & 6.2 & 5.2 & 27.0 & \multirow{6}{*}{ 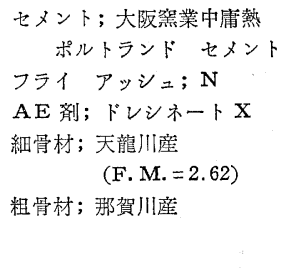 } \\
\hline " & " & " & $"$ & " & " & 7.1 & 5.5 & - & \\
\hline " & " & $"$ & " & " & 1.9 & 6.3 & 5.5 & 27.0 & \\
\hline " & " & 20 & 127 & 37.5 & 23 & 6.8 & 5.2 & - & \\
\hline " & " & " & " & " & 20 & 6.2 & 5.4 & 26.8 & \\
\hline " & " & " & " & " & $"$ & 5.7 & 5.0 & 26.8 & \\
\hline 120 & 180 & 0 & 98 & 24.0 & 5.0 & 3.3 & 3.6 & 21.1 & \multirow{8}{*}{ 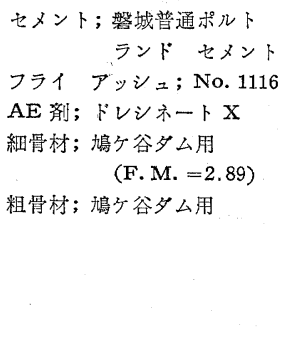 } \\
\hline " & " & " & " & $"$ & 5.1 & 3.4 & 3.4 & 19.7 & \\
\hline " & " & " & " & " & 5.5 & 4.5 & 3.7 & 18.6 & \\
\hline$"$ & " & $"$ & " & " & 5.5 & 4.0 & 3.5 & 19.6 & \\
\hline$"$ & " & 30 & 91 & 23.9 & 65 & 4.0 & 3.5 & 21.7 & \\
\hline " & $"$ & " & " & $"$ & 68 & 5.5 & 4.6 & 19.3 & \\
\hline " & $"$ & " & " & " & 56 & 4.4 & 3.6 & 19.2 & \\
\hline " & $"$ & $"$ & $"$ & " & 59 & 4.3 & 4.1 & 20.0 & \\
\hline
\end{tabular}


表一4。11 コンクリートのブリージング試験結果

\begin{tabular}{|c|c|c|c|c|c|c|c|c|c|c|c|c|c|c|c|c|c|c|c|}
\hline \multirow{3}{*}{$\begin{array}{l}\text { 測 定 } \\
\text { 時 間 } \\
\text { (分) }\end{array}$} & \multicolumn{4}{|c|}{ 単位セメント・フライ } & \multicolumn{4}{|c|}{ アッシュ量 $=280 \mathrm{~kg} / \mathrm{m}^{3}$} & \multicolumn{6}{|c|}{ 単位セメント・フラ } & \multicolumn{5}{|c|}{ アッンロ量 $=180 \mathrm{~kg} / \mathrm{m}^{3}$} \\
\hline & \multicolumn{3}{|c|}{$\begin{array}{l}\text { フライ アッシュ } \\
\text { オ乎カエ率 }\end{array}$} & \multirow{2}{*}{$\frac{0 \%}{\text { 平均 }}$} & \multicolumn{3}{|c|}{$\begin{array}{l}\text { フライ アッシュ } \\
\text { 乎カ土率 }\end{array}$} & $20 \%$ & \multicolumn{6}{|c|}{ フライ アッッンュ $0 \%$} & \multicolumn{5}{|c|}{$\begin{array}{l}\text { フライイアッシュ } \\
\text { オキガ率 }\end{array}$} \\
\hline & 1 & 2 & 3 & & 1 & 2 & 3 & 平均 & 1 & & & 3 & 4 & 平均 & 1 & 2 & 3 & 4 & 平均 \\
\hline 20 & 0.27 & 0.23 & .29 & 26 & 0.28 & .19 & 3 & 0.27 & 00 & & & 0.19 & 0.18 & 0.16 & 0.00 & 0.11 & 0.10 & 0.28 & 0.12 \\
\hline 40 & 0.72 & 0.75 & 0.71 & 0.73 & 0.61 & 0.44 & 1.05 & 0.70 & 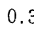 & & & 0.55 & 0.63 & 0.49 & 0 . & 0.38 & 0.49 & 0.49 & 0.4 \\
\hline 60 & 1.61 & 1.27 & 25 & 38 & 96 & 4 & 37 & 1.09 & 6 & & & 0.95 & 1.0 & 0.89 & 0.5 & 0.7 & 0.85 & 0.91 & 0.7 \\
\hline 80 & 2.12 & 1.85 & 1.82 & 1.93 & 1.39 & .33 & 2.04 & 1.59 & & & & 1.39 & 1.38 & 1.23 & 0.81 & 1.13 & 1.05 & 1.41 & 1.1 \\
\hline 100 & 2. & 2.36 & 2.22 & 2.44 & 2.01 & 1.75 & 2. & 2. & 1.3 & & & .70 & 1.72 & 1.55 & 1.1 & 1.67 & 1.60 & 1.79 & 1.5 \\
\hline 120 & 3.36 & 2.92 & 2.63 & 2.97 & 2.44 & 2.08 & 2.96 & 2.49 & 6 & & & .05 & 2.1 & 1.92 & 1.44 & 2.15 & 2.06 & 2.2 & .9 \\
\hline 140 & 3 & 3 & 2.90 & 3 & 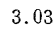 & 2.38 & . & 2. & 1.8 & & & 2.47 & 2.50 & 2.31 & 1.73 & 2.59 & 2.34 & 2.53 & 2.30 \\
\hline 160 & 4.07 & 3.46 & 2.94 & 3.49 & 3.34 & 2.72 & 3.5 & 3. & & & & 2.85 & 2.97 & 2 & 1 & 2. & 2. & 2.95 & 2.69 \\
\hline 180 & 4.13 & 3.47 & 2.94 & 3.51 & 3.52 & 2.98 & 3.53 & 3.34 & 2 & & & 3.16 & 3.38 & 2.87 & 2.38 & 3.28 & 3.35 & 3.30 & 3.0 \\
\hline 200 & 4.13 & 3.47 & 2.94 & 3.51 & 3.52 & 3.07 & 3.53 & 0.01 & & & & 3.54 & 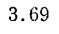 & 3.07 & 2.61 & 3.64 & 3.63 & 3.92 & 3.45 \\
\hline 220 & - & - & - & - & - & - & - & - & & & & 3.85 & 4.07 & 3.26 & 2.73 & 3.95 & 3.86 & 4.11 & 3.6 \\
\hline 240 & - & - & - & - & - & - & - & - & 2.3 & & & .90 & 4.13 & 3.28 & 2.90 & 4.25 & 4.22 & 4.28 & 3.91 \\
\hline 260 & - & - & - & - & - & - & - & - & & & & 3.9 & 4.16 & 3.30 & 2.93 & 4.52 & 4.48 & 4.28 & 4.00 \\
\hline 280 & - & - & - & - & - & - & - & - & 2.3 & & & 3.92 & 4.19 & 3.30 & $2 . \subseteq$ & 4.66 & 4.51 & 4.28 & 4.10 \\
\hline 300 & - & - & - & - & - & - & - & - & - & & & - & - & - & 2.93 & 4.67 & 4.53 & 4.28 & 4.10 \\
\hline
\end{tabular}

そ従つて試験したが，その結果は表一4・12 亿示すと扔りである。

これらから次のことが羿められる。

（1）ポルトランド セメントの一部をフライ アッシュで挌きか光 て造つたコンクリートのブリージングは，フライ アッシュを用い ないものにくらべて, 本試験の範囲の平均值によれば, 富配合の場合

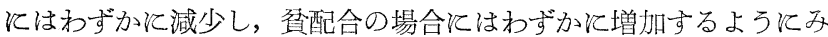
られる。しかし，このような試験方法による場合，同一系列の3〜4 回の試験結果の間には相当の変動が生じ，このことを一般的傾向と するととは困難であると思われる。

(2) 一方, モルタルのブリージングについては，ポルトランド セ メントの一部をフライ アッシュで持きか光た場合には，フライア ッシュを用いないものよりわずか炕多くなることが認められる。

(3) ポルトランド セメントの一部をフライアッシュで招きか党 て造つたコンクリートは，フライ アッシュを用いないものに比し て，コンシステンシー和よびプラスチシチーがいちじるしくよくな ることが認められ，実際の施工に当つてはコンクリート材料の分離 が少なく，従つて全体としてのブリージングもまた少なくなるよう 炕考光られる。

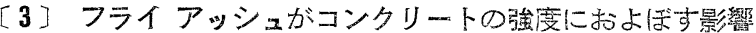

約 $20^{\circ} \mathrm{C}$ の水中養生を行う場合，良質のフライ アッシュでセメン 卜の一部を招きかて造つそコンクリートの強度は，早期材令汇物 いては，フライ アッシュを用いないものよりも強度が弱くなるが，

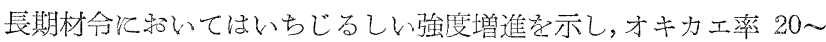
40\%のわのはフライ アッシュを用いないものよりも強くなる。乘沈 オキカエ率 $50 \%$ のむのです材令 6 月ないし1年でフライ アッシュ を用いないるのより強くなつた実験結果む岁る。このフライアッ シュオキカエ率と压繀強度の関係秐よび材令の增加炕ともなう強度 増進率は，フライ アッシュの品質・コンクリートの配合・セメン
図一4・8 フライ アッシュを用いた コンクリートのブリージング

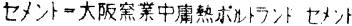
フライ アッシューハ 票位セ犬シト:フライ アッシュ量 $=280 \mathrm{kq} \mathrm{m}^{\mathrm{s}}$

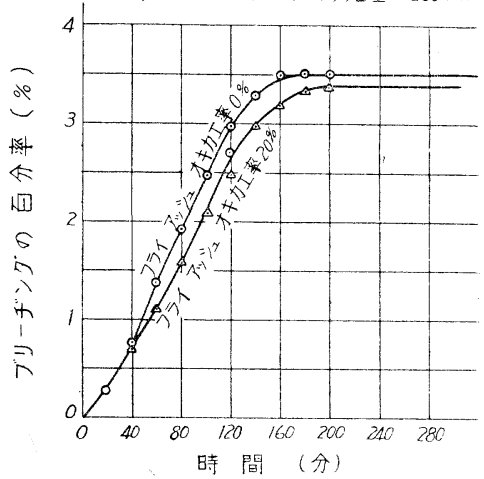

セメント = 整城普通ポルトラントセダ

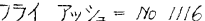
墨位セメント・フライ アッシュ墨=180 k $\mathrm{m}^{\mathrm{s}}$

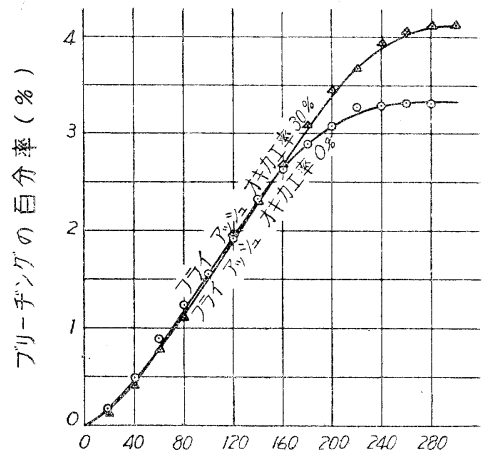

時間(分) 
表一4・12 モルタルのブリージング試験に用いた配合およびその結果

\begin{tabular}{|c|c|c|c|c|c|c|c|c|}
\hline 試 駱 & 合 回 & 数 & 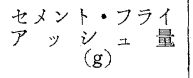 & $\begin{array}{c}\text { フライ アッシ学 } \\
\text { オ } \\
\substack{\text { カ } \\
(\%)}\end{array}$ & 水 $(\text { c.c. })^{\text {量 }}$ & $>\underset{(\%)}{\square}-$ & 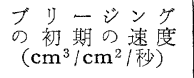 & $\begin{aligned} \text { ブリーシング量 } \\
\left(\mathrm{cm}^{3} / \mathrm{cm}^{3}\right)\end{aligned}$ \\
\hline 第 & 1 & 回 & \multirow{4}{*}{750} & \multirow{4}{*}{0} & \multirow{4}{*}{375} & \multirow{4}{*}{107} & $60.7 \times 10^{-6}$ & $21.4 \times 10^{-3}$ \\
\hline 第 & 2 & 回 & & & & & 60.3 " & $21.3 "$ \\
\hline 第 & \multirow[t]{2}{*}{3} & 回 & & & & & 48.5 " & 16.8 \\
\hline 平 & & 均 & & & & & $56.5 \Rightarrow$ & 19.8 \\
\hline 第 & 1 & 回 & \multirow{4}{*}{750} & \multirow{4}{*}{20} & \multirow{4}{*}{375} & \multirow{4}{*}{107} & $73.7 \times 10^{-6}$ & $27.8 \times 10^{-3}$ \\
\hline 第 & 2 & 回 & & & & & 66.4 " & 22.7 \\
\hline 第 & \multirow[t]{2}{*}{3} & 回 & & & & & $66.4 "$ & $24.6 "$ \\
\hline 平 & & 均 & & & & & 68.8 " & $25.3 "$ \\
\hline 第 & 1 & 回 & \multirow{4}{*}{750} & \multirow{4}{*}{40} & \multirow{4}{*}{360} & \multirow{4}{*}{107} & $62.8 \times 10^{-6}$ & $26.3 \times 10^{-3}$ \\
\hline 第 & 2 & 回 & & & & & $67.6 "$ & 24.2 " \\
\hline 第 & 3 & 回 & & & & & 63.4 " & 24.7 \\
\hline 平 & & 均 & & & & & $64.6 ”$ & $25.1 \mathrm{~N}$ \\
\hline
\end{tabular}

トの種類・養生方法・などそ左右される。次にこれらの諸因子がフライ アッシュを用いたコンクリートの圧緥

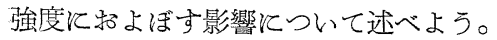

1. フライアッシュの品質がコンクリートの圧縮強度に怙よぼす影響 13 種のフライ アッシュを用いた場 合, 表一 4.6 飞示した配合のコンクリートについて約 $20^{\circ} \mathrm{C}$ の水中養生を行い，その圧縮強度を試験した結果讨 表一4・13 と示すと呿りである。

表一4・13 品質の相違するフライ アッシュを用いたコンクリートの圧縮強度

\begin{tabular}{|c|c|c|c|c|c|c|c|c|c|c|}
\hline \multirow{2}{*}{$\begin{array}{l}\text { 実 . 験 } \\
\text { 整理番号 }\end{array}$} & \multicolumn{3}{|c|}{ フライ アッシュ } & \multirow{2}{*}{ 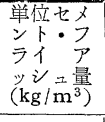 } & \multirow{2}{*}{ 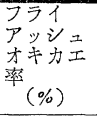 } & \multicolumn{4}{|c|}{ 圧縮強度 $\left(\mathrm{kg} / \mathrm{cm}^{2}\right)$} & \multirow[b]{2}{*}{ 備 } \\
\hline & 名 称 & $\begin{array}{c}\text { 强熱減量 } \\
(\%)\end{array}$ & $\begin{array}{l}\text { ブレーン } \\
\text { 此表面積 } \\
\left(\mathrm{cm}^{2} / \mathrm{g}\right)\end{array}$ & & & 28 日 & 91 日 & 6 月 & 1 年 & \\
\hline \multirow{6}{*}{001} & - & - & - & \multirow{6}{*}{306} & 0 & 215 & 268 & 296 & 313 & \multirow{6}{*}{$\begin{array}{l}\text { 1. 供試体は } 10 \times 20 \mathrm{~cm} \\
\text { 月柱である。 } \\
\text { 2. 各試験値は供試体 } 3 \text { 個の平 } \\
\text { 均值である。 } \\
\text { 3. } \mathrm{AE} \text { 剂は用いない。 }\end{array}$} \\
\hline & A & 1.6 & 3680 & & 20 & 190 & 276 & 329 & 332 & \\
\hline & B & 2.4 & 3270 & & $"$ & 183 & 263 & 313 & 339 & \\
\hline & D & 2.0 & 2660 & & " & 185 & 247 & 316 & 327 & \\
\hline & $\mathrm{E}$ & 2.6 & 3110 & & " & 161 & 220 & 282 & 301 & \\
\hline & $\mathrm{H}$ & 1.9 & 2410 & & " & 163 & 215 & 280 & 287 & \\
\hline \multirow{9}{*}{003} & - & - & - & \multirow{9}{*}{280} & 1 & 283 & 355 & 359 & 363 & \multirow{9}{*}{$\begin{array}{l}\text { 1. 供詿体は } 10 \times 20 \mathrm{~cm} \text { 月柱 } \\
\text { である。 } \\
\text { 2. 各試験值は供試体 } 3 \text { 個の平 } \\
\text { 均值である。 } \\
\text { 3. AE 剂はビンソル レヂン } \\
\text { を使用。 }\end{array}$} \\
\hline & B & 2.4 & 3270 & & 20 & 238 & 344 & 400 & 400 & \\
\hline & C & 3.0 & 3240 & & " & 235 & 343 & 396 & 400 & \\
\hline & $\mathrm{F}$ & 1.9 & 2760 & & " & 228 & 336 & 378 & 397 & \\
\hline & $\mathrm{K}$ & 1.5 & 3180 & & " & 238 & 340 & 392 & 410 & \\
\hline & $\mathrm{L}$ & 1.3 & 2810 & & $"$ & 243 & 342 & 395 & 401 & \\
\hline & $\mathbf{M}$ & 1.4 & 3290 & & " & 249 & 345 & 381 & 400 & \\
\hline & $\mathrm{N}$ & 0.9 & 3460 & & " & 259 & 352 & 398 & 427 & \\
\hline & $\mathrm{O}$ & 2.4 & 2940 & & " & 228 & 329 & 353 & 373 & \\
\hline \multirow{6}{*}{004} & - & - & - & \multirow{6}{*}{280} & 0 & 294 & 342 & 366 & 348 & \multirow{6}{*}{$\begin{array}{l}\text { 1. 供試体は } 10 \times 20 \mathrm{~cm} \text { 円柱 } \\
\text { である。 } \\
\text { 2. 各試験値は供試体 } 3 \text { 個の平 } \\
\text { 均値である。 } \\
\text { 3. AE 阂はドレンネート X } \\
\text { 使用。 }\end{array}$} \\
\hline & B & 2.4 & 3270 & & 20 & 243 & 358 & 397 & 396 & \\
\hline & $\mathrm{C}$ & 3.0 & 3240 & & " & 251 & 339 & 402 & 405 & \\
\hline & $\mathrm{L}$ & 1.3 & 2810 & & " & 231 & 327 & 347 & 381 & \\
\hline & $\mathrm{M}$ & 1.4 & 3290 & & " & 251 & 331 & 374 & 364 & \\
\hline & $\mathrm{Q}$ & 0.7 & 3620 & & " & 260 & 369 & 405 & 415 & \\
\hline
\end{tabular}

表一4・13 より次のことが認められる。 
（1）フライ アッシュを用いたコンクリートの压縮強度は，フライ アッシュの粉末度が細かいほど，大きく でる傾向にある。また，粉末度が細かいものほど早期に強度が増進する傾向にある。

しか乙実験：003 そ扮いて８種のフライ アッシュを用いたコンクリートの圧縮強度は，材令 28 日では， $228 \sim 259 \mathrm{~kg} / \mathrm{cm}^{2}$ の範囲にあつてその変動係数は $4.1 \%$, 材令 1 年では, $373 \sim 427 \mathrm{~kg} / \mathrm{cm}^{2}$ の範囲にあつてその 変動係数は $3.5 \%$ である。従つてこの範囲のフライ アッシュは，実用上ほぼ同程度とみなしてさしつかえない ようと思われる。

2. フライアッシュオキカエ率执よびコンクリートの配合が圧縮強度に抒よぼす影響 表一4・7 に示した配 合のうち, 実験 : $011 \cdot 101 \cdot 102$ のコンクリートについて，約 $20^{\circ} \mathrm{C}$ の水中養生を行い，その圧縮強度を試験し た結果は，表一4·14 および 図一4.9 そ示すと括りである。

表一4.14 フライ アッシュ オキカエ率と圧縮強度との関係

\begin{tabular}{|c|c|c|c|c|c|c|c|c|c|c|c|}
\hline \multirow{2}{*}{$\begin{array}{c}\text { 実験整 } \\
\text { 理番号 }\end{array}$} & \multirow{2}{*}{ 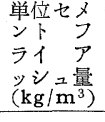 } & \multirow{2}{*}{$\left|\begin{array}{|l}\text { フライ } \\
\text { Pッシ } \\
\text { オキカ工 } \\
\text { 率 } \\
(\%)\end{array}\right|$} & 王 & 縮 & 強 & \multicolumn{2}{|c|}{ 度 $\quad\left(\mathrm{kg} / \mathrm{cm}^{2}\right)$} & \multicolumn{3}{|c|}{28 日強度に対する比 } & \multirow[b]{2}{*}{ 備考 } \\
\hline & & & 日 & 28 日 & 91 日 & 6 月 & 1 年 & 91 日 & 6 月 & 1 年 & \\
\hline \multirow{15}{*}{011} & \multirow{5}{*}{239} & 0 & $72(1.00)$ & $132(1.00)$ & $157(1.00)$ & $174(1.00)$ & $187(1.00)$ & 1.15 & 1.27 & 1.36 & \multirow{5}{*}{$\begin{array}{l}\text { 1. 供供試体は } \\
15 \times 30 \mathrm{~cm} \text { 円柱 } \\
\text { である。 } \\
\text { 2. 各試験値は供試 } \\
\text { 体 } 3 \text { 個の平均值 } \\
\text { である。 }\end{array}$} \\
\hline & & 10 & $69(0.96)$ & $125(0.95)$ & $170(1.08)$ & $190(1.13)$ & $224(1.20)$ & 1.36 & 1.52 & 1.79 & \\
\hline & & 20 & $65(0.90)$ & $120(0.91)$ & $168(1.07)$ & $213(1.22)$ & $231(1.24)$ & 1.40 & 1.77 & 1.93 & \\
\hline & & 30 & $59(0.82)$ & $107(0.81)$ & $161(1.02)$ & $209(1.20)$ & $239(1.28)$ & 1.51 & 1.95 & 2.23 & \\
\hline & & 50 & $40(0.56)$ & $73(0.55)$ & $122(0.78)$ & $180(1.03)$ & $233(1.25)$ & 1.67 & 2.46 & 3.19 & \\
\hline & \multirow{5}{*}{285} & 0 & $125(1.00)$ & $219(1.00)$ & $256(1.00)$ & $287(1.00)$ & $281(1.00)$ & 1.17 & 1.31 & 1.28 & \multirow{10}{*}{ s" } \\
\hline & & 10 & $117(0.94)$ & $211(0.96)$ & $284(1.11)$ & $325(1.13)$ & $331(1.18)$ & 1.35 & 1.54 & 1.57 & \\
\hline & & 20 & $111(0.89)$ & $199(0.91)$ & $278(1.09)$ & $321(1.12)$ & $340(1.21)$ & 1.40 & 1.61 & 1.71 & \\
\hline & & 30 & $94(0.75)$ & $169(0.77)$ & $261(1.02)$ & $321(1.12)$ & $337(1.20)$ & 1.54 & 1.90 & 1.99 & \\
\hline & & 50 & $66(0.53)$ & $121(0.55)$ & $201(0.79)$ & $269(0.94)$ & $305(1.09)$ & 1.66 & 2.22 & 2.52 & \\
\hline & \multirow{5}{*}{354} & 1 & $223(1.00)$ & $350(1.00)$ & $399(1.00)$ & $419(1.00)$ & $433(1.00)$ & 1.14 & 1.20 & 1.24 & \\
\hline & & 10 & $219(0.98)$ & $345(0.99)$ & $430(1.08)$ & $460(1.10)$ & - & 1.25 & 1.33 & - & \\
\hline & & 20 & $196(0.88)$ & $313(0.89)$ & $428(1.07)$ & $480(1.15)$ & $492(1.14)$ & 1.37 & 1.53 & 1.57 & \\
\hline & & 30 & $175(0.79)$ & $279(0.80)$ & $406(1.02)$ & $461(1.10)$ & $486(1.12)$ & 1.45 & 1.65 & 1.74 & \\
\hline & & 50 & $126(0.57)$ & $214(0.61)$ & $321(0.81)$ & $380(0.91)$ & $418(0.97)$ & 1.50 & 1.78 & 1.95 & \\
\hline \multirow{4}{*}{101} & \multirow{4}{*}{180} & 0 & 一 & $174(1.00)$ & $254(1.00)$ & $254(1.00)$ & $254(1.00)$ & 1.46 & 1.46 & 1.46 & \multirow{8}{*}{$\begin{array}{l}\text { 1. 供試体は } 15 \times 30 \\
\mathrm{~cm} \text { 円柱て， } 40 \\
\mathrm{~mm} \text { 以上の骨材 } \\
\text { をふるい去つた } \\
\text { コンクリートで } \\
\text { 製造した。 } \\
\text { 2. 各試験値俚供試 } \\
\text { 体 } 3 \text { 個の平均値 } \\
\text { である。 }\end{array}$} \\
\hline & & 20 & - & $123(0.71)$ & $236(0.93)$ & $270(1.06)$ & $282(1.11)$ & 1.92 & 2.20 & 2.29 & \\
\hline & & 30 & - & $93(0.53)$ & $212(0.83)$ & $249(0.98)$ & $296(1.17)$ & 2.28 & 2.68 & 3.18 & \\
\hline & & 40 & - & $75(0.43)$ & $202(0.80)$ & $251 .(0.99)$ & $301(1.19)$ & 2.69 & 3.35 & 4.02 & \\
\hline \multirow{4}{*}{102} & \multirow{4}{*}{180} & 0 & - & $119(1.00)$ & $226(1.00)$ & $253(1.00)$ & $265(1.00)$ & 1.90 & 2.13 & 2.23 & \\
\hline & & 20 & - & $80(0.67)$ & $226(1.00)$ & $256(1.01)$ & $305(1.15)$ & 2.82 & 3.20 & 3.81 & \\
\hline & & 30 & - & $73(0.61)$ & $192(0.85)$ & $239(0.95)$ & $303(1.14)$ & 2.63 & 3.27 & 4.15 & \\
\hline & & 40 & - & $59(0.50)$ & $135(0.60)$ & $204(0.81)$ & $230(0.87)$ & 2.29 & 3.46 & 3.90 & \\
\hline
\end{tabular}

カッコ内の数值は基準配合の強度に対する比を示したものである。

表一4・14 招よび 図一-4.9 より次のととが認められる。

（1）フライ アッシュを用いたコンクリートの圧縮強度は, 早期材令ではフライアッシュオキカエ率が増すほ ど弱くなるが，長期材令ではいちじるしい強度増進を示し，材令約 1 年程度では，フライ アッシュオキカエ率 50\% 程度まで，フライ アッシュを用いない場合よりも強くなるか，あるいはほぼ同程度になる。またフライ アッシュを用いたコンクリートの材令の増加とともなう強度増進率は, フライ アッシュオキカ工率が増すほど 大きくなる。

（2）フライアッシュオキカエ率と圧縮強度との関係は，比較的早期材令においては，配合の筫富飞関せずほ :゙一定であるが，長期材令においては，䬸配合のコンクリートほどフライアッシュの効果がより顕著にあらわ れてくる。 
これは,フライ アッシュとセメント中の遊 離石灰の結合飞必要な水分が，セメントの水和 後活けるコンクリート中の残存水分飞よつて まかなわれるとすれば，この残存水分は一般に 梖配合に括けるほど多いことによるものではな いかと考觉られる。

3. フライアッシュが普通括よび中庸熱ポ ルトランドセメントを゙用いたコンクリートの 圧縮強度に怙よぼす影響 小野田普通ポルトラ ンドセメントおよび 小野田中庸熱ポルトラン ドセメントの 2 種のセメントとフライ アッシ ュ を用い，粗骨材の最大寸法 $30 \mathrm{~mm}$, 単位セ メント・フライ アッシュ量 $280 \mathrm{~kg} / \mathrm{m}^{3}$, フラ イアッシュオキカエ率 $0 \cdot 20 \%$ ， スランプ 4 ・ $6 \mathrm{~cm}$, のコンクリートについて, 約 $20^{\circ} \mathrm{C}$ 水中 養生を行い，その压縮強度を試験した結果は 表一4・15 のと打りである。この数值にもとづ いて，それぞれの圧縮強度拉よび基準配合に対 する圧縮強度百分率と材令との関係を示せば，

\section{図一4・10 亿示すと招りである。}

すなわち，フライ アッシュで普通ポルトラ ンドセメント执よび中庸熱ポルトランド セメ ントの一部を特きかえたコンクリートの，材令 の増加飞ともなう圧縮強度の増進状態は，フ ライ アッシュを用いない基準配合のコンクリ 一トの年れ支配され，一般には，石灰分の多 い早強性のセメントの方が，フライ アッシュ を用いる場合には条件がよいよう教党られ る。

\section{図一4.9 フライ アッシュ オキカエ率 亡圧縮強度亡の関係}
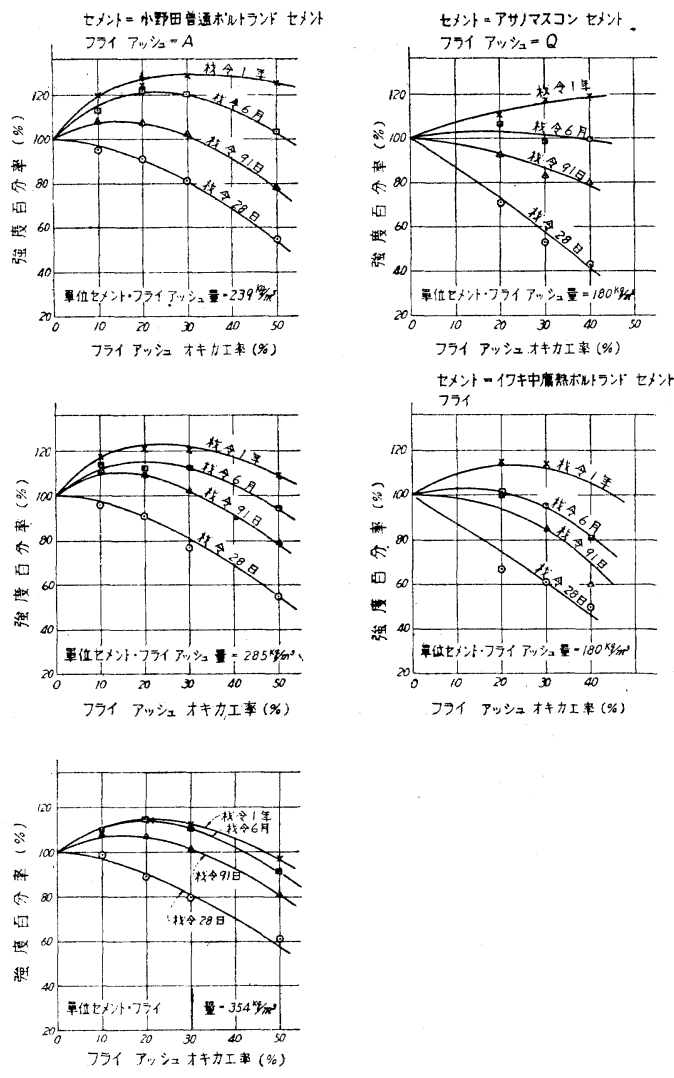

表一4・15 セメントの相違する場合におけるフライ アッシュを 用いたコンクリートの圧縮強度

\begin{tabular}{|c|c|c|c|c|c|c|c|c|}
\hline \multirow{2}{*}{$七$} & \multirow{2}{*}{ 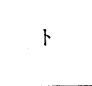 } & \multirow{2}{*}{$\begin{array}{l}\text { フライ ア } \\
\text { ッンュオキ } \\
\text { カエ率 }(\%)\end{array}$} & \multirow{2}{*}{$\begin{array}{l}\text { 単位水量 } \\
\left(\mathrm{kg} / \mathrm{m}^{3}\right)\end{array}$} & \multirow{2}{*}{$\begin{array}{l}\text { スランプ } \\
(\mathrm{cm})\end{array}$} & 泎 & 繀 & 度 & $\left(\mathrm{kg} / \mathrm{cm}^{2}\right)$ \\
\hline & & & & & 28 & 91 & 月 & 1 \\
\hline \multirow{4}{*}{\multicolumn{2}{|c|}{$\begin{array}{l}\text { 小野田普通ポルトランド } \\
\text { （津 久 見 エ 場 }\end{array}$}} & \multirow[t]{2}{*}{0} & \multirow[t]{2}{*}{168} & \multirow[t]{2}{*}{4} & 238 & \multirow{2}{*}{$\begin{array}{c}310 \\
(1.00)\end{array}$} & \multirow{2}{*}{$\begin{array}{c}328 \\
(1.00)\end{array}$} & 330 \\
\hline & & & & & $(1.00)$ & & & $(1.00)$ \\
\hline & & 20 & 156 & 4 & 201 & 305 & \multirow{2}{*}{$\begin{array}{c}358 \\
(1.09)\end{array}$} & 398 \\
\hline & $\begin{array}{l}\text { セメント } \\
\text { 製) }\end{array}$ & & & & $(0.85)$ & $(0.99)$ & & (1.21) \\
\hline \multirow{4}{*}{\multicolumn{2}{|c|}{$\begin{array}{l}\text { 小野田中庸熱ポルトランド セ } \\
\text { ト } \\
\text { （津 久 見 エ 場 製） }\end{array}$}} & 0 & 168 & 6 & 162 & \multirow{2}{*}{$\begin{array}{c}246 \\
(1.00)\end{array}$} & \multirow{2}{*}{$\begin{array}{c}284 \\
(1.00)\end{array}$} & \multirow{2}{*}{$\begin{array}{c}347 \\
(1.00)\end{array}$} \\
\hline & & & & & $(1.00)$ & & & \\
\hline & & 20 & 156 & 6 & 127 & 246 & 308 & 397 \\
\hline & & & & & $(0.78)$ & $(1.00)$ & $(1.08)$ & (1.14) \\
\hline
\end{tabular}

\footnotetext{
1.フライ アッンュは $\mathrm{N}$ を用いた。

2. 粗骨材の最大寸法は $30 \mathrm{~mm}$. 単位セメント・フライ アッンニ量は $280 \mathrm{~kg} / \mathrm{m}^{3}$ である。

備考 3. 練り混ぜたときのコンクリート温度は約 $10^{\circ} \mathrm{C}$ でありた。

4. 供試体は $15 \times 30 \mathrm{~cm}$ 月柱, 試験值は供試体 3 個の平均值である。

5. $20^{\circ} \mathrm{C}$ 水中善生を行つた場合のものである。
} 
図一4・10 セメントの相違するフライ アッシュを用いたコンクリートの圧縮強度
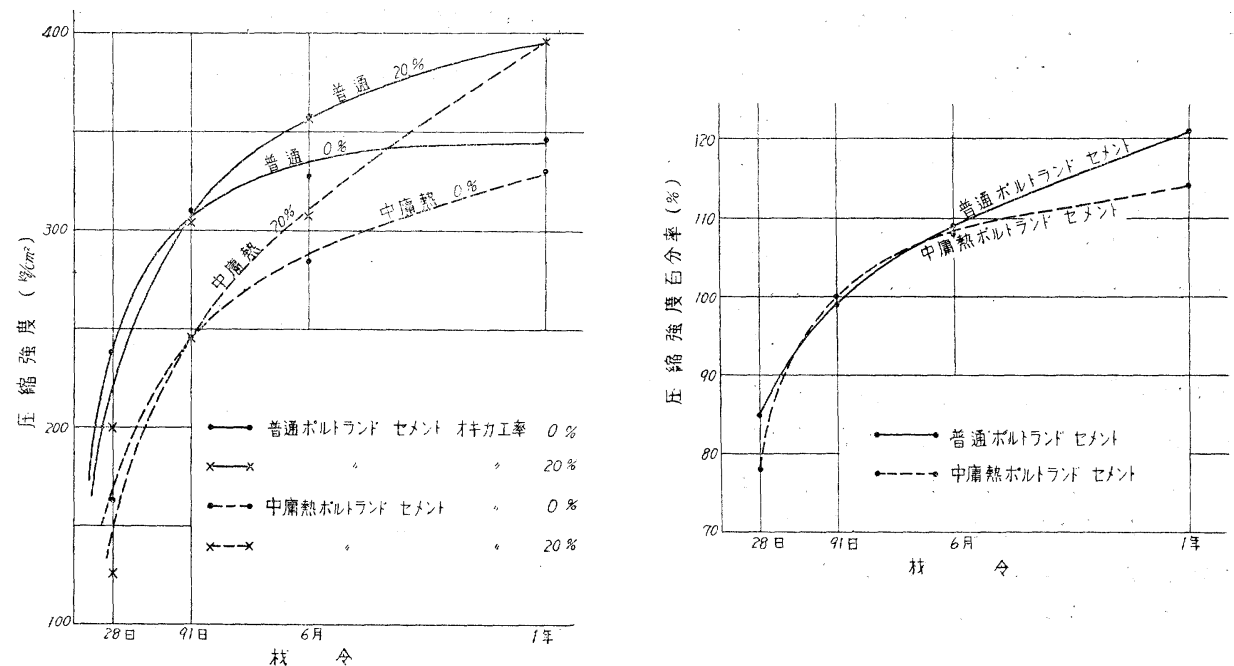

4. 養生方法がフライ アッシュを用いたコンクリートの圧縮強度に和よぼす影響 表一4・7 の実験：104亿示 した配合のコンクリートを，それぞれ $10 \cdot 20 \cdot 38^{\circ} \mathrm{C}$ の水中招よび露天放置で養生した場合の圧縮強度試験結果 は，表一4・16 特よび 図一 $4 \cdot 11$ 亿示すと扮りである。

表一4・16＼cjkstart養生方法がフライ アッシュを用いたコンクリートの圧縮強度におよぼす影響

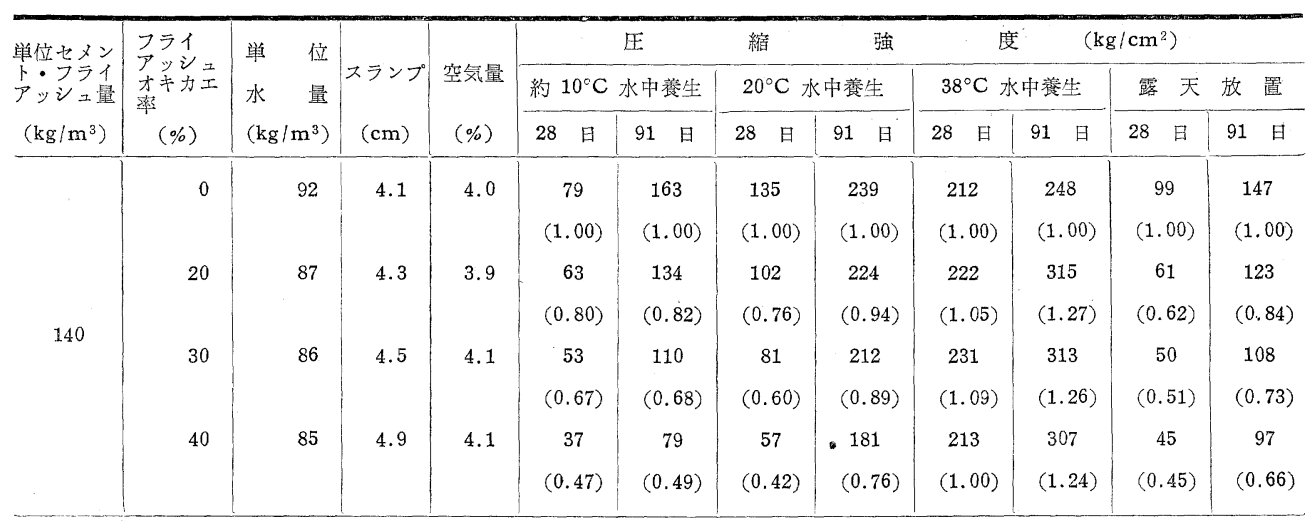

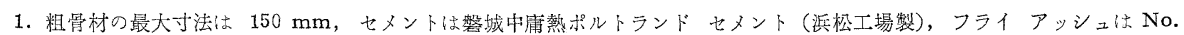
723 である。

觜考| 2. 練り混ぜたときのコンクリート温度は約 $9^{\circ} \mathrm{C}$ であつた。

3、王縮強度試験に用いた供試体は $10 \times 20 \mathrm{~cm}$ 冈柱で, $20 \mathrm{~mm}$ 以上の骨材をふるい去つたコンクリートについて試験した。

4. 露天放置期間中 $\left(1 \sim 4\right.$ 月) の平均温度は約 $10^{\circ} \mathrm{C}$ でありた。

図一4·11 養生方法が相違するフライ アッシュ コンクリートの圧縮強度

材令: 29 开

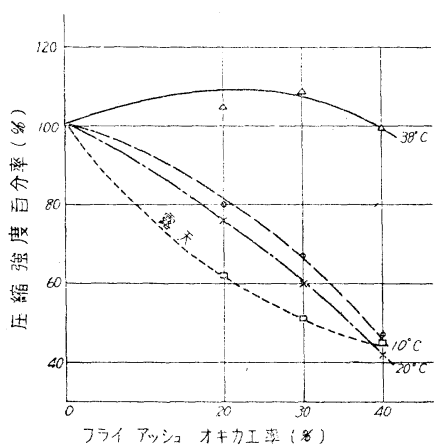

材令: 91 日

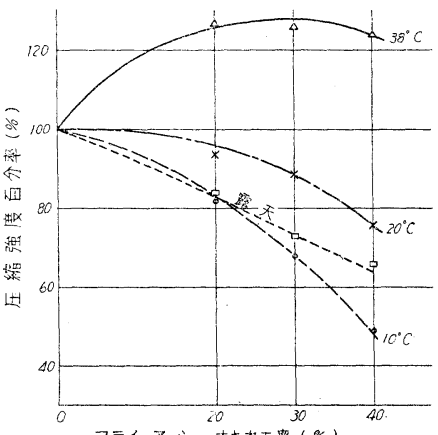


これらのことから次のようなととが認められる。

(1) フライアッシュを用いたコンクリートの早期材令に和ける圧縮強度は， $10^{\circ} \mathrm{C}$ 㐨よび $20^{\circ} \mathrm{C}$ 水中養生を行 つた場合にはフライ アッシュを用いないものよりむ小さいが， $30^{\circ} \mathrm{C}$ 水中養生を行つた場合には，フライアッシ ユを用いないむのよりも強くなる。

（2）フライアッシュを用いたコンクートは，10・20・38 C のいずれの養生温度に括いても，材令の増加とと むなつて強度の増進がみられる。28 日より 91 日への強度増進の割合は， $10^{\circ} \mathrm{C}$ の養生温度では，才キカエ率の

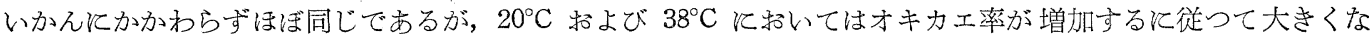
る (表一 $4 \cdot 17$ 参照)。

（3）露天放置のままで養生した場合汸いても，フラ イアッシュを用いたコンクリートの材令増加汇ともな う強度の増進は，フライアッシュを用いないものより も大きく，表一4·17 亿示すように，材令 91 日強度の 28 日強度注対する比は，フライ アッシュを用いないもの が，約 1.5 であるのに対し，フライアッシュを用いた あのは約 2.0〜2.2 となつている。この実験江括いては，

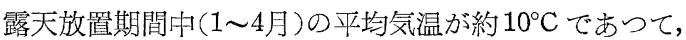
圧縮強度招よびその増進率は，約 $10^{\circ} \mathrm{C}$ の水中養生そ行

表一4·17 養生条件をかえたフライ アッシュ を用いたコンクリートの 91 日強度 と28 日強度との比

\begin{tabular}{|c|c|c|c|c|}
\hline \multirow{2}{*}{$\begin{array}{c}\text { フライ アッシ } \\
\text { ュオキカ率 } \\
\text { オ }\end{array}$} & 養 & 生. 温 & 度 & \multirow{2}{*}{ 露天放置 } \\
\hline & $10^{\circ} \mathrm{C}$ & $20^{\circ} \mathrm{C}$ & $30^{\circ} \mathrm{C}$ & \\
\hline 0 & 2.1 & 1.8 & 1.2 & 1.5 \\
\hline 20 & 2.1 & 2.2 & 2.0 & 2.0 \\
\hline 30 & 2.1 & 2.6 & 2.2 & 2.2 \\
\hline 40 & 2.1 & 3.2 & 2.2 & 2.2 \\
\hline
\end{tabular}

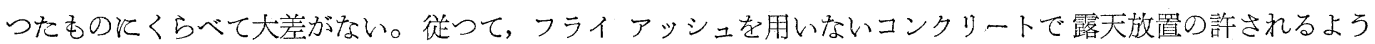

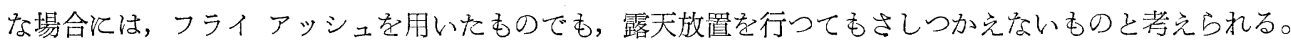

5. フライ アッシュがコンクリートの引張強度に抒よぼす影響 表-4・7の実験：011（単位セメント・フライ アッシュ量 $\left.285 \mathrm{~kg} / \mathrm{m}^{3}\right)$ 飞示した配合のコンクリートを, 約 $20^{\circ} \mathrm{C}$ の水中養生を行い, 材令 $7 \cdot 28 \cdot 91$ 日・6月 ・1年飞执いて引張強さ係数を試験した結果は 表一4・18 のと和りである。

表一4・18フライ アッシュを用いたコンクリートの引張強さ係数

\begin{tabular}{|c|c|c|c|c|c|c|c|c|c|c|c|c|c|c|c|}
\hline \multirow{2}{*}{ 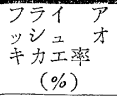 } & 引 & 張 & d & \multicolumn{2}{|c|}{ 数 $\left(\mathrm{kg} / \mathrm{cm}^{2}\right)$} & \multicolumn{10}{|c|}{ 压縮強度 / 引張強さ係数 } \\
\hline & 7 日 & 28 日 & 91 日 & 月 & 1 年 & 7 & 日 & 28 & 日 & 91 & 日 & 6 & 月 & 1 & 年 \\
\hline 0 & $\begin{array}{r}12.2 \\
(1.00)\end{array}$ & $\begin{array}{r}18.4 \\
(1.00)\end{array}$ & $\begin{array}{r}22.1 \\
(1.00)\end{array}$ & $\begin{array}{r}24.1 \\
(1.00)\end{array}$ & $\begin{array}{r}23.1 \\
(1.00)\end{array}$ & & 0.2 & & 1.9 & & 1.6 & & 11.9 & & 12.2 \\
\hline 10 & $\begin{array}{r}12.1 \\
(0.99)\end{array}$ & $\begin{array}{r}18.1 \\
(0.98)\end{array}$ & $\begin{array}{r}23.5 \\
(1.06)\end{array}$ & $\begin{array}{r}27.2 \\
(1.13)\end{array}$ & $\begin{array}{r}26.9 \\
(1.16)\end{array}$ & & 9.7 & & 1.7 & & 2.1 & & 11.9 & & 12.3 \\
\hline 20 & $\begin{array}{r}11.2 \\
(0.92)\end{array}$ & $\begin{array}{r}16.5 \\
(0.90)\end{array}$ & $\begin{array}{r}22.2 \\
(1.00)\end{array}$ & $\begin{array}{r}28.0 \\
(1.16)\end{array}$ & $\begin{array}{r}27.2 \\
(1.18)\end{array}$ & & 9.9 & & 2.1 & & 2.5 & & 11.5 & & 12.5 \\
\hline 30 & $\begin{array}{r}9.2 \\
(0.75)\end{array}$ & $\begin{array}{r}14.3 \\
(0.78)\end{array}$ & $\begin{array}{r}20.6 \\
(0.93)\end{array}$ & $\begin{array}{r}27.2 \\
(1.13)\end{array}$ & $\begin{array}{r}26.5 \\
(1.15)\end{array}$ & & 10.2 & & 1.8 & & 12.7 & & 11.8 & & 12.7 \\
\hline 50 & $\begin{array}{r}6.6 \\
(0.54)\end{array}$ & $\begin{array}{r}11.1 \\
(0.60)\end{array}$ & $\begin{array}{r}17.7 \\
(0.80)\end{array}$ & $\begin{array}{l}26.7 \\
(1.11)\end{array}$ & $\begin{array}{r}26.9 \\
(1.17)\end{array}$ & & 10.0 & & 10.9 & & 11.4 & & 10.1 & & 11.3 \\
\hline
\end{tabular}

1. セメントは小野田普通ポルトランド セメント,フライ アッシュは $\mathrm{A}$ を用いた。

2. 粗骨材の最大寸法沈 $30 \mathrm{~mm}$, 単位セメント・フライ アッンュ量は $285 \mathrm{~kg} / \mathrm{m}^{3}$, スランプ法 $4 \mathrm{~cm}$ で岁る。

備考 3. 練り混ぜたときのコンクリート温度は約 $25^{\circ} \mathrm{C}$ でありた。

4. 供試体は $15 \times 20 \mathrm{~cm}$ 月柱である。

5. 各試験值法供試体 4 個の平均值である。

すなわち,フライ アッシュを用いたコンクリートの引張強さ係数とフライ アッシュ オキカエ率との関係招よ び材令の増加とともなう引張強さ係数の増進割合は，圧縮強度の場合とほぼ同じであつて，特沉フイアッシ ュの効果が圧縮強度の場合上りも引張強さ係数汇执いていちじるしいという傾向は認められない。この表の実験 例和よび 1 4 4゙述べたととから，フライ アッシュの品質・コンクリートの配合・セxントの種類・湌生方法な どがフライ アッシュを用いたコンクリートの引張強度に扮よぼす影響は，压縮強度の場合とほぼ同じであろう と考觉られる。

\section{〔4〕フライ アッシュがコンクリートの透水性におよぼす影響}

実験に用いた配合を示せば，表一4·19 のと抒りであり，これを〔1]4亿述べた方法で試験を行つた結果は，

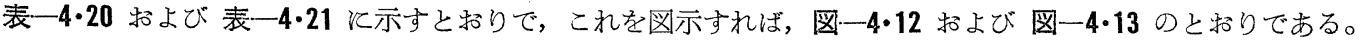


表一4·19透水試験に用いたコンクリートの配合

\begin{tabular}{|c|c|c|c|c|c|c|c|c|c|}
\hline 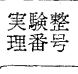 & セメント & $\begin{array}{l}\text { フラライ } \\
\text { アッシェ }\end{array}$ & $\begin{array}{c}\text { 粗骨材の } \\
\text { 最大寸法 } \\
\text { (mm) }\end{array}$ & 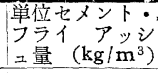 & 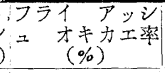 & $\begin{array}{l}\text { 単位水量 } \\
\left(\mathrm{kg} / \mathrm{m}^{3}\right)\end{array}$ & \begin{tabular}{|l} 
粗細骨材 \\
重 量 比
\end{tabular} & $\begin{array}{l}\text { スランプ } \\
(\mathrm{cm})\end{array}$ & 備 \\
\hline 015 & $\begin{array}{l}\text { 小野田普通ポ } \\
\text { ルトランド } \\
\text { せメント } \\
\text { (津久見工場 } \\
\text { 製) }\end{array}$ & B & 25 & 300 & $\begin{array}{r}0 \\
20 \\
30\end{array}$ & $\begin{array}{l}180 \\
172 \\
168\end{array}$ & 1.30 & $\begin{array}{l}6.5 \\
6.5 \\
6.5\end{array}$ & 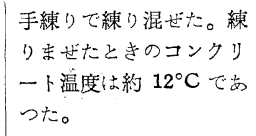 \\
\hline 016 & " & $\mathbf{N}$ & 15 & 300 & $\begin{array}{r}0 \\
20\end{array}$ & $\begin{array}{l}201 \\
189\end{array}$ & 0.86 & $\begin{array}{l}6 \\
6\end{array}$ & 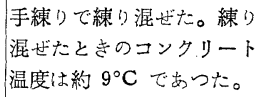 \\
\hline
\end{tabular}

表一4・20 フライ アッシュを用いたコンクリートの透水試験結果

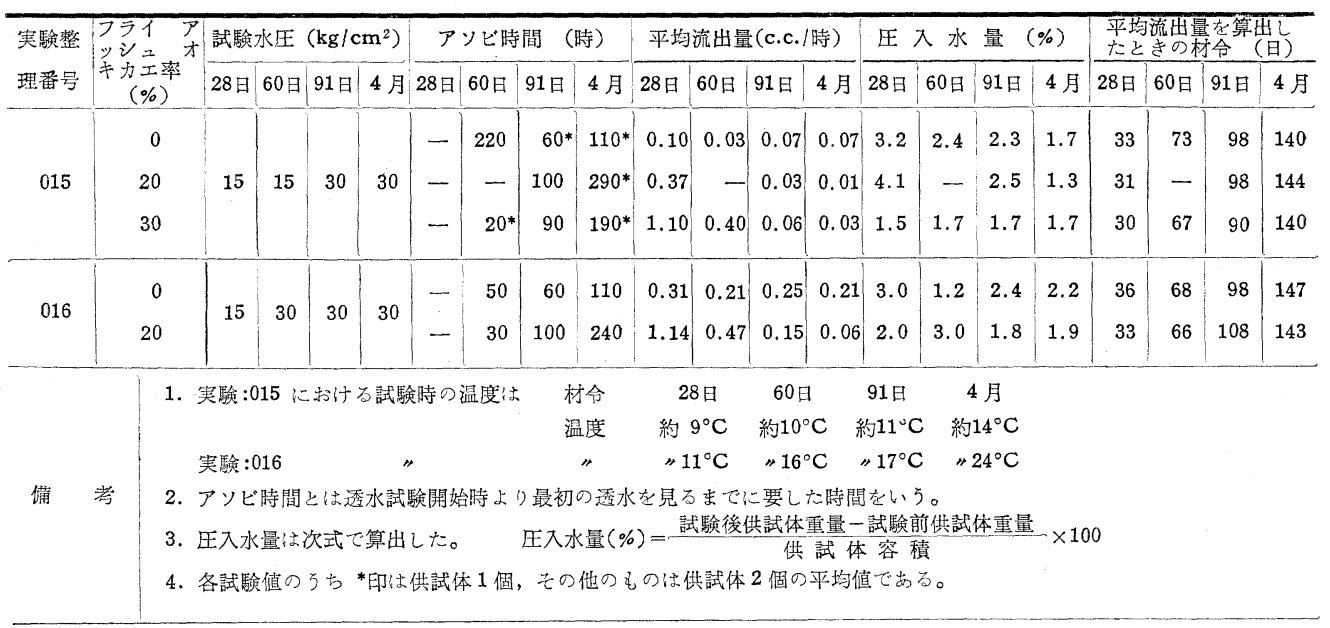

図一4:12 フライ アッシュを用いたコ ンクリートの材令之耐透水指 数および圧縮強度との関係

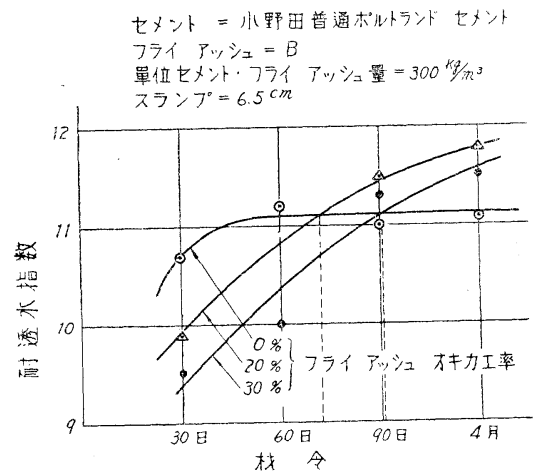

図一4.13 フライ アッシュを用いたコ ンクリートの材令と耐透水指 数および圧縮強度との関係
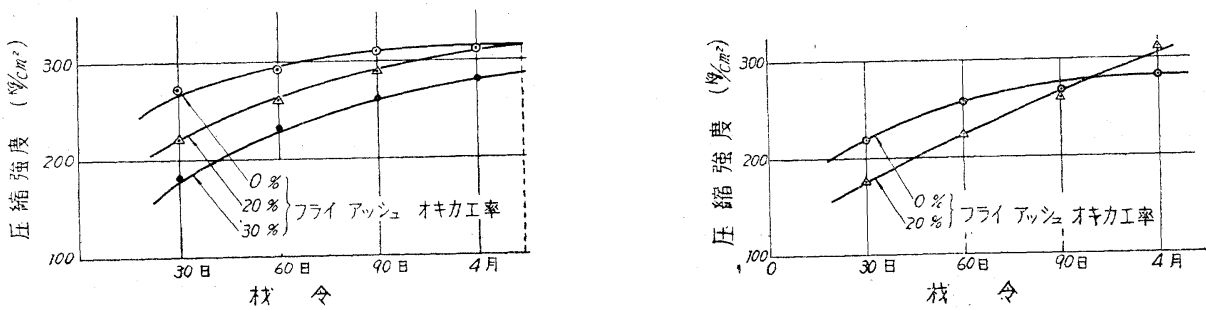
表一4.21 フライ アッシュを用いたコンクリートの耐透水指数と圧縮強度

\begin{tabular}{|c|c|c|c|c|c|c|c|c|c|c|c|c|c|}
\hline \multirow{2}{*}{$\begin{array}{l}\text { 実 験整 } \\
\text { 理 番号 }\end{array}$} & \multirow{2}{*}{ 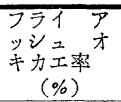 } & \multicolumn{4}{|c|}{ 透水係数 $\times 10^{12}(\mathrm{~cm} /$ 秒 $)$} & 耐 & \multicolumn{2}{|c|}{ 透 水 指 } & 数 & \multicolumn{4}{|c|}{ 生縮強度 $\left(\mathrm{kg} / \mathrm{cm}^{2}\right)$} \\
\hline & & 28 日 & 60 日 & 91 日 & 4 月 & 28 日 & 60 日 & 91 日 & 4 月 & 28 日 & 60 日 & 91 日 & 4 月 \\
\hline \multirow{3}{*}{015} & 0 & 28 & 6.5 & 9.0 & 8.1 & 10.7 & 11.2 & 11.0 & 11.1 & 271 & 291 & 310 & 310 \\
\hline & 20 & 98 & - & 4.0 & 1.5 & 9.9 & - & 11.5 & 11.8 & 220 & 258 & 291 & 307 \\
\hline & 30 & 324 & 93 & 7.1 & 3.5 & 9.5 & 10.0 & 11.3 & 11.5 & 181 & 231 & 261 & 279 \\
\hline \multirow{2}{*}{016} & 0 & 76 & 22 & 27 & 19 & 10.2 & 10.7 & 10.6 & 10.7 & 217 & 256 & 267 & 282 \\
\hline & 20 & 290 & 53 & 16 & 5.4 & 9.6 & 10.3 & 10.8 & 11.3 & 175 & 222 & 260 & 311 \\
\hline
\end{tabular}

これらの表执よび罒から次のととが認められる。

(1) 約 $20^{\circ} \mathrm{C}$ で水中養生を行つた場合, 普通ポルトランド セメントを用いたコンクリートの耐䢪水性は, 材令 60 日くらいまで増進するが，それ以後はほとんどその増進が認められない。これに対し，セメント重量の 20〜 30\%をフライ アッシュで招きかえたコンクリートの耐透水性は，早期材命に颃いてはフライアッシュを用いな いものよりも劣るが，材令の増加とともに逐次増大し，長期材令飞招いてはフライアッシュを用いないむのよ

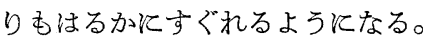

(2) 普通ポルトランド セメントの一部をフライ アッシュで招きかえたコンクリートの耐透水性が，フライ アッシュを用いないコンクリートの耐透水性をこす材令は，オキカエ率 $30 \%$ のものは $20 \%$ のものよりも長い。

(3) また，普通ポルトランド セメントの一部をフライ アッシュで招きかえたコンクリートと，フライアッ シュを用いないコンクリートの両者飞招いて，耐透水性の方が圧縮強度よりも早期の材令に招いて一致する。こ れは, フライ アッシュがコンクリートの圧繀強度に対するよりも, 耐透水性化対して有効働らくことを意味 するとみることができる。

（4）以上のことより，耐透水性の要求される構造物とフライ アッシュを用いれば，きわめて有利な場合があ るものと考光られる。

〔5〕フライ アッシュがコンクリート の耐久性におよぼす影響

1. 凍結融解飞対する抵抗性 表一 $4 \cdot 22$ に試験を行つたコンクリートの配合とその 結果を示す。

(1) フライ アッシュでセメントの一部 を招きか光た（０・20・30\%）実験：022 の配合のコンクリートを約 $20^{\circ} \mathrm{C}$ の水中養 生を行い，材令 28 日招よび 4 月飞括いて 凍結融解試験を開始した結果, 供試体の重 量変化招よび動弾性係数の変化は図一 $4 \cdot 14$ に示すようになつた。材令 28 日より開始 した場合には，フライアッシュを用いた コンクリートの凍結融解に対する抵抗性は フライアッシュを用いないむのよりもわ ずか江少るように思われる。すなわち凍結 融解に対する抵抗性の尺度として, 動弾性 係数の減少率をとれば, フライ アッシュ を用いたものも用いないむのもほぼ同程度 の抵抗性を有することが認められるが，重 量の減少率をとる場合《は, フライアッシ ユを用いないものに比べて，フライアッ シュを用いたむのは，オキカエ率が増すほ ぞ, 重量の減少率は大きくなつている。し かて, 材令 4 月飞和けるフライ アッシュ
図一414 フライ アッシュを用いたコンク リートの凍結融解試験結果
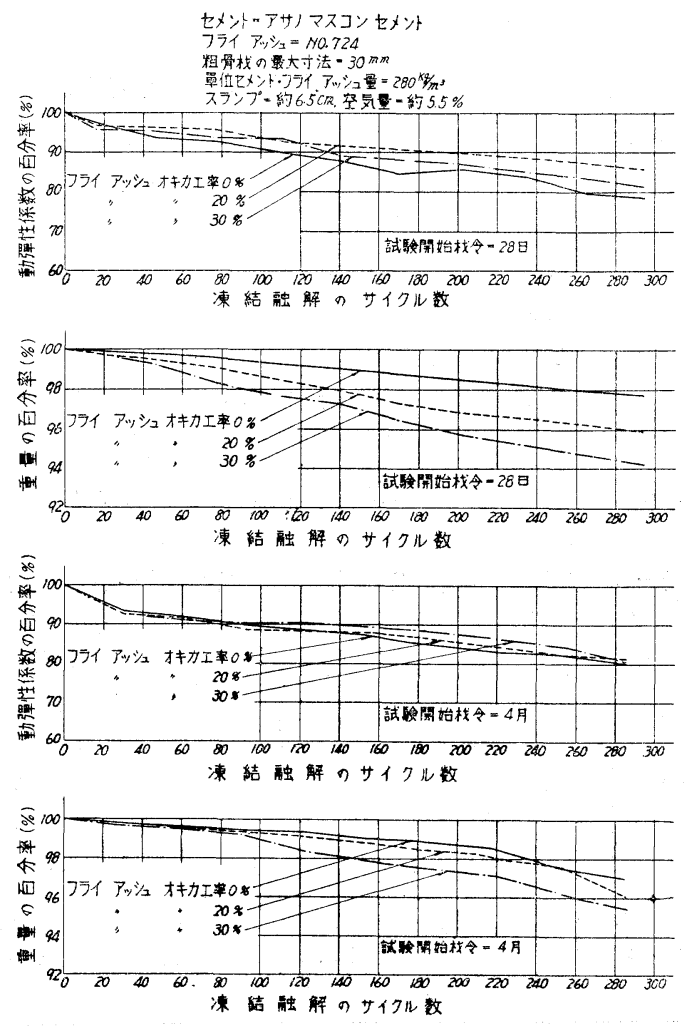
表-4.22 フライアアッシュコた

\begin{tabular}{|c|c|c|c|c|c|c|c|c|c|c|}
\hline $\begin{array}{l}\text { 実 䮖 } \\
\text { 整理番号 }\end{array}$ & $\begin{array}{l}\text { 水セxント・ } \\
\text { フライ アッ } \\
\text { ンこ重量比 }\end{array}$ & $\begin{array}{c}\text { スランプ } \\
(\mathrm{cm})\end{array}$ & $\begin{array}{c}\text { 空気量 } \\
(\%)\end{array}$ & $\begin{array}{c}\text { 粗縕骨材 } \\
\text { 重 量 比 } \\
\text { (G/S) }\end{array}$ & セメント & $\begin{array}{l}\text { フライ } \\
\text { アッシェ }\end{array}$ & 細骨材 & 粗 骨材 & 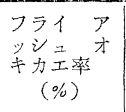 & $\begin{array}{c}\text { 単位水量 } \\
\left(\mathrm{kg} / \mathrm{m}^{3}\right)\end{array}$ \\
\hline \multirow{6}{*}{022} & 0.50 & 6.5 & 5.6 & 1.70 & \multirow{6}{*}{ 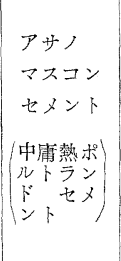 } & $+\quad \Sigma$ & 楫 保川 & 那賀川 & 0 & 141 \\
\hline & 0.48 & " & 5.2 & " & & No. 724 & $"$ & $"$ & 20 & 133 \\
\hline & 0.47 & " & 5.5 & " & & $"$ & " & " & 30 & 130 \\
\hline & 0.50 & " & 5.6 & $"$ & & $ナ \quad$ 广 & $"$ & $"$ & 0 & 141 \\
\hline & 0.48 & $"$ & 5.2 & $"$ & & No. 724 & $"$ & " & 20 & 133 \\
\hline & 0.47 & $"$ & 5.5 & " & & " & " & " & 30 & 130 \\
\hline \multirow{4}{*}{003} & 0.54 & 8.0 & 5.0 & 1.68 & \multirow{4}{*}{$\begin{array}{l}\text { 小野田普 } \\
\text { 通ポルト } \\
\text { シント } \\
\text { セメント }\end{array}$} & $ナ \quad$ ナ & 大和 川 & 日高川 & 0 & 152 \\
\hline & 0.51 & 7.0 & 5.2 & " & & $\mathrm{L}$ & $"$ & $"$ & 20 & 143 \\
\hline & 0.51 & " & 5.1 & " & & $\mathrm{N}$ & " & $"$ & " & 143 \\
\hline & 0.50 & " & 4.7 & " & & M & $"$ & " & " & 140 \\
\hline \multirow{4}{*}{004} & 0.54 & 5.5 & 5.1 & 1.60 & \multirow{4}{*}{ " } & ナ $\quad$ v & $"$ & $"$ & 0 & 150 \\
\hline & 0.51 & 5.0 & 4.9 & " & & $\mathrm{B}$ & " & " & 20 & 142 \\
\hline & 0.52 & " & 4.8 & " & & C & $"$ & $"$ & " & 144 \\
\hline & 0.51 & $"$ & 4.9 & " & & $Q$ & " & " & " & 140 \\
\hline
\end{tabular}

（1）単位セメント・フライ アッンュ量 $=280 \mathrm{~kg} / \mathrm{m}^{3}$, 粗骨材の最大寸法 $=30 \mathrm{~mm}$

備 考 $\begin{aligned} & \text { (2) 試験開始時にお汁る圧縮強度 } \\ & \text { には } 10 \times 10 \times 21 \mathrm{~cm} \text { ではない。 }\end{aligned}$

（3）实験:003に涴ける $\mathrm{AE}$ 剂はビンソル レヂンを用いた。

を用いたコンクリートの凍結融解汇対する抵抗性は，フラ イアッシュを用いないものとほ济同程度である。すなわ 占材令 4 月飞括いては, 動弹性係の減少率も重量の減少率 もほぼ同程度となつている。

な招材令 4 月で涷結融解試験を開始し，394 サイクルま で湅結融解をくり返したのちの角柱供試体を中央部で切断 乙，相切半した供試体の切断面を加圧面として圧縮強度試 験を行つた結果は, 表一4・23飞示すと怙りである。これに よると、フライアッシュを用いないむのむ用いたものも ほぼ同じである。

(2) 6 種のフライ アッシュを用いて, 表-4.6 の実験： 003 执よび笑験：004の配合のコンクリートを約 $20^{\circ} \mathrm{C} の$ 水 中で養生し，それぞれ 11 月拉よび 8 月で谏結融解試験を 開始し, 約 250 サイクルホで行つた試験の結果は 図一4・15 のと和りである。

\section{表一4.23 凍結融解試験を行なつたコンクリートの強度}

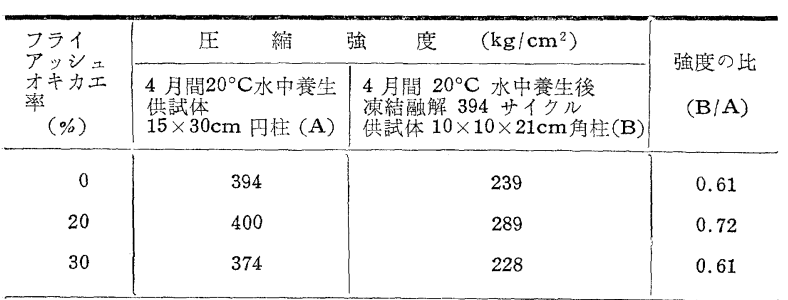

1. (A) は供試体 2 個の平均値, (B) 洪試体 4 個の平均值でるる。 備考 2. (B) の供詿体は谏結融解試験に上り供試体表面が損粍したためそ の寸法は正確には $10 \times 10 \times 21 \mathrm{~cm}$ ではない。
図一4.15 フライ アッシュを用いたコンク リートの凍結融解試験結果
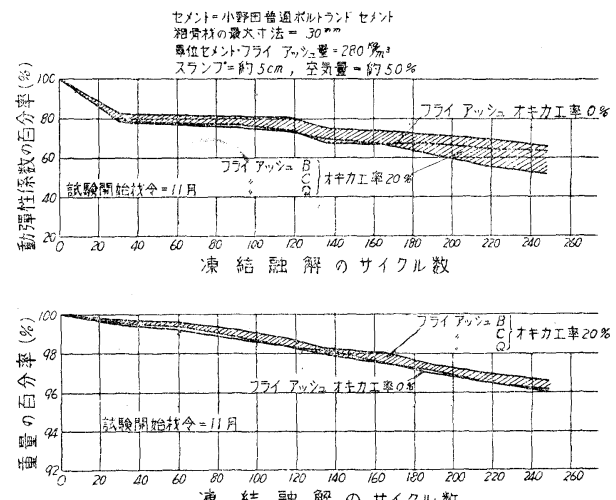
捸結融解のサイクル数

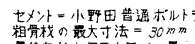

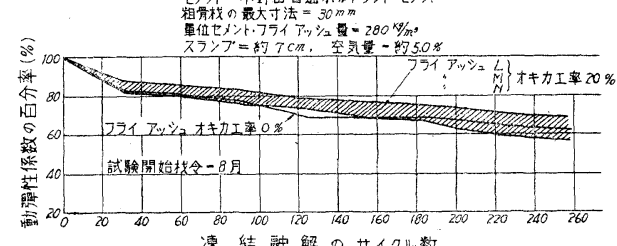
楛結融解のサイフル数

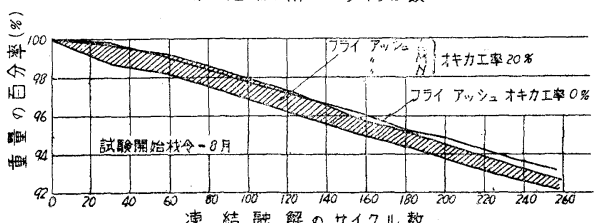


クリートの㣀 結 融 解 試 験 の 結 果

\begin{tabular}{|c|c|c|c|c|c|c|c|c|c|}
\hline \multirow{2}{*}{$\begin{array}{c}\text { 単位ドVシ } \\
\text { ホート量 } \\
\left(\mathrm{g} / \mathrm{m}^{3}\right)\end{array}$} & \multicolumn{4}{|c|}{ 試 験 開 始 㭙 の 供試 体 } & \multirow{2}{*}{$\begin{array}{l}\text { 凍結融解 } \\
の \\
\text { サイル } \\
\text { 数 }\end{array}$} & \multicolumn{2}{|c|}{ 試験終了時の供試体 } & \multicolumn{2}{|c|}{ 試䮅による変化 } \\
\hline & 材令 & $\begin{array}{l}\text { 压 縮 強 度 } \\
\left(\mathrm{kg} / \mathrm{cm}^{2}\right)\end{array}$ & 重 $(\mathrm{kg})^{\text {量 }}$ & 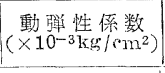 & & 重 $(\mathrm{kg})^{\text {量 }}$ & $\left(\times 10^{-3} \mathrm{~kg} / \mathrm{cm}^{2}\right)$ & $\begin{array}{c}\text { 再量の百 } \\
\text { 分率 } \\
(\%)\end{array}$ & $\begin{array}{c}\begin{array}{c}\text { 動弾性係数 } \\
\text { の百分率 } \\
(\%)\end{array} \\
\end{array}$ \\
\hline 7.0 & 28 日 & 293 & 9.860 & 337 & 294 & 9.564 & 265 & 97.7 & 78.5 \\
\hline 31.0 & $"$ & 222 & 9.832 & 328 & $"$ & 9.429 & 281 & 95.9 & 85.8 \\
\hline 46.0 & " & 183 & 9.826 & 321 & " & 9.246 & 260 & 94.1 & 81.1 \\
\hline 7.0 & 4 月 & 394 & 9.948 & 378 & 252 & 9.699 & 311 & 97.5 & 82.2 \\
\hline 31.0 & " & 400 & 9.861 & 377 & " & 9.624 & 310 & 97.6 & 82.3 \\
\hline 46.0 & $"$ & 374 & 9.882 & 370 & " & 9.506 & 313 & 96.2 & 84.5 \\
\hline 21.0 & 8 月 & - & 9.700 & 375 & 257 & 9.040 & 231 & 93.2 & 61.9 \\
\hline 28.0 & " & - & 9.565 & 378 & " & 8.809 & 241 & 92.1 & 63.8 \\
\hline 37.0 & " & - & 9.575 & 375 & " & 8.828 & 213 & 92.2 & 56.8 \\
\hline 65.0 & " & - & 9.675 & 380 & " & 8.969 & 262 & 92.7 & 68.9 \\
\hline 6.5 & 11 月 & - & 9.689 & 372 & 248 & 9.301 & 237 & 96.0 & 63.7 \\
\hline 23.0 & $"$ & - & 9.800 & 386 & " & 9.428 & 226 & 96.2 & 58.6 \\
\hline 38.0 & $"$ & - & 9.800 & 382 & " & 9.467 & 197 & 96.6 & 51.5 \\
\hline 8.5 & $"$ & - & 9.890 & 402 & $"$ & 9.554 & 263 & 96.6 & 65.5 \\
\hline
\end{tabular}

ける压縮強度は $10 \times 10 \times 21 \mathrm{~cm}$ 角柱供試体 4 個の平均值である。な秥角柱供試体は谏結融解試験に上り表面が侵されたため, その寸法は

この図から次のことが認められる。

（i）粉末度が $88 \mu$ フルイ残分で $5 \%$ 以下，ブレーン比表面積で $3000 \mathrm{~cm}^{2} / \mathrm{g}$ 程度以上，強熱減量が約 $4 \%$ 以下の良質のフライ アッシュを用いる場合には，その品質に関係なく，それらのフライアッシュが凍結融解に 対する抵抗性に括よす影響は，ほぼ同程度であると考光られる。

（ii）図一4・15 亿示した実験飞招いては，凍結融解約 250 サイクル後の動弾性係数の減少率は，約 $31 \sim 49 \%$ であり，図一4·14 亿示した実験と招けるとれは約 14〜22\%であつて，前者はかなり大きい值を示しているが， これは主として用いたセメント抽よび骨材の種類が相違することによるものと思われる。

2. 硫酸りーダ溶液汶対する抵抗性

(1) フライアッシュを用いたモルタルに関する耐酼酸塩試験：而㧧酸塩試験に用いたモルタル供試体は $5 \times$ $10 \mathrm{~cm}$ 円柱で, 製造後約 200 日間 $20^{\circ} \mathrm{C}$ 水中養生を行つたものである。試液としては, 硫酸りーダの $21^{\circ} \mathrm{C}$ に怙け る飽和溶液を用いた。試験は，2週間ごと飞容器から供試体を取出し，ゆるんだ粒子和よび侵食された部分がこ とごとくなくなるまでワイヤ ブラシでこすり取つたのち, 湿布で供試体の表面の水滴をふき, その重量を $\mathrm{g} ま$ で測定し，供試体の重量の変化をるつて硫酸塩の作用に対する抵抗性の尺度とした。

表一4・24 フライ アッシュを用いたモルタルの耐硫酸塩試験結果

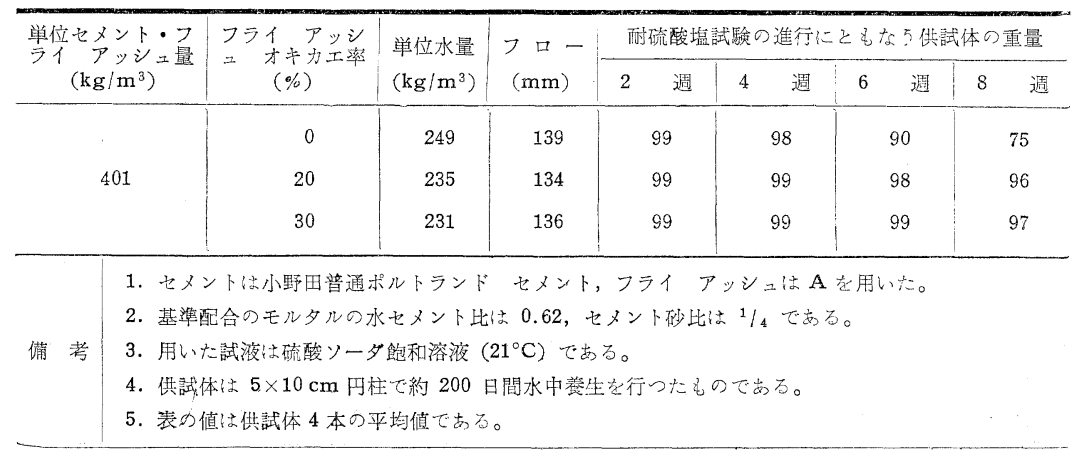


すなわちフライ アッシュを用いたモルタルは，フライアッシ 二を用いないものに比べて, 硫酸塩の作用に対していちじるしく 抵抗性を増す。このととは，供試体の外観を見ただけであいちじ るしい相違がただち認められた。

(2) フライアッシュを用いたコンクリートに関する耐硫酸塩 試験：実験飞用いたコンクリートは表一4.25 亿示すと抒りであ る。試液は, 硫酸ソーダ $10 \%$ 溶液を用い, 供試体は $10 \times 20 \mathrm{~cm}$ 円柱を用いて，6月間 $20^{\circ} \mathrm{C}$ 水中養生を行つたのち 6 月間試液江 浸した。試験はそれらの供試体を試液から取り出して圧縮強度試 験を行い，その結果と $20^{\circ} \mathrm{C}$ 水中養生を 1 年間行つた供試体の圧 縮強度とを比較することにより判定した。これらの試験の結果を 示せば 表一4・25 のと扮りである。
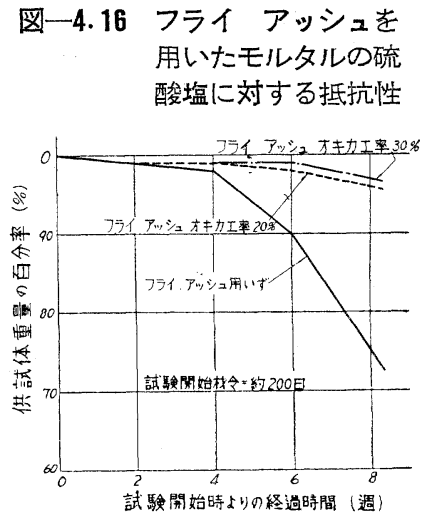

表一4・25 フライ アッシュを用いたコンクリートの耐硫酸塩試験結果

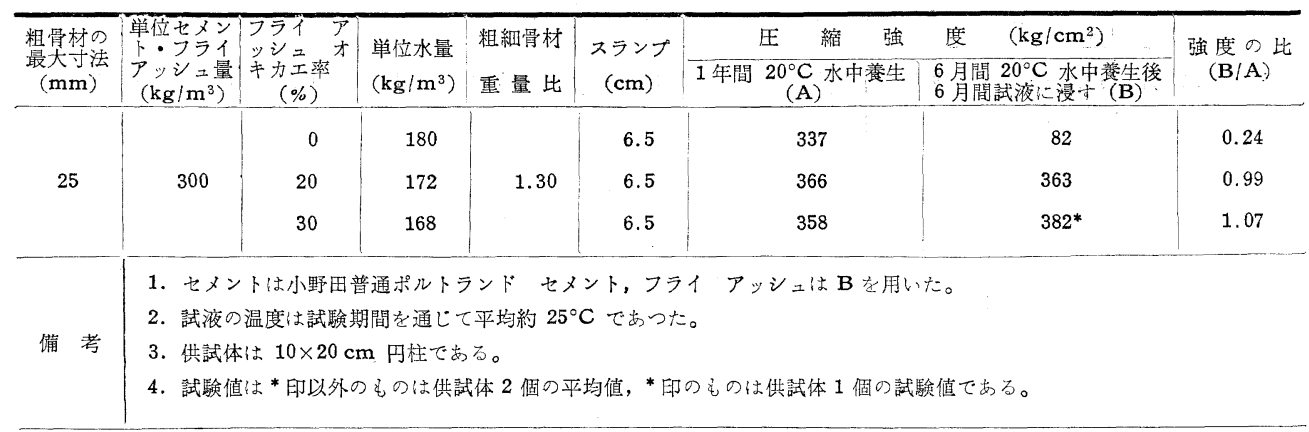

すなわち，フライ アッシュを用いたコンクリートに関する実験和いても，モルタルの場合と全く同様に，フ ライアッシュは，硫酸塩対して卓越した抵抗を有することが垫められる。ただし，この場合には，供試体の 外観上はあまり差異を認められなかつた。

な扮，これらの試験は，而㧧酸塩試験方法自体としては多少適当でない点もあるが，少なくとも硫酸塩の作用 飞対するフライ アッシュの効果を確かめる目的に対しては，なんら支障ないものと考光る。

〔6〕フライ アッシュがコンクリートの水和熱による温度上昇におよぼす影響

（i）アサノ マスコンセメントとフライ アッシュBを用い, 粗骨材の最大寸法を $80 \mathrm{~mm}$, 単位セメント・ フライアッシュ量を $180 \mathrm{~kg} / \mathrm{m}^{3}$, スランプを約 $2 \mathrm{~cm}$, 空気量を約 $4 \%$ としたダム用コンクリートについて, フライアッシュオキカエ率を $0 \cdot 30 ・ 50 \%$ とした場合（実験：103）

（ii）磐城中庸熱ポルトランド セメント（七尾工場製）とフライ アッシュ Q を用い，粗骨材の最大寸法を

表一4・26 フライ アッシュを用いたコンクリートの断熱温度上昇に関する試験結果

\begin{tabular}{|c|c|c|c|c|c|c|c|c|c|c|}
\hline 実験整理 & \multirow{2}{*}{$\begin{array}{c}\text { 粗骨材の } \\
\text { 聚封法 } \\
\text { (mm) }\end{array}$} & \multirow{2}{*}{$\begin{array}{l}\text { 単位七メン } \\
\text { トンフィ } \\
\text { アッシニ量 } \\
\left(\mathrm{kg} / \mathrm{m}^{3}\right)\end{array}$} & \multirow{2}{*}{ 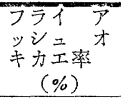 } & \multirow{2}{*}{$\begin{array}{l}\text { 単位水量 } \\
\left(\mathrm{kg} / \mathrm{m}^{3}\right)\end{array}$} & \multirow{2}{*}{$\begin{array}{c}\text { スランブ } \\
(\mathrm{cm})\end{array}$} & \multirow{2}{*}{$\begin{array}{c}\text { 空 気量 } \\
(\%)\end{array}$} & \multirow{2}{*}{\begin{tabular}{|l|} 
試験開始時の \\
温度 ${ }^{\circ}\left({ }^{\circ} \mathrm{C}\right)$
\end{tabular}} & \multicolumn{3}{|c|}{ 試験開始時上りの温度上昇 $\left({ }^{\circ} \mathrm{C}\right)$} \\
\hline 番 号 & & & & & & & & 日 & 3 & 7 日 \\
\hline \multirow{3}{*}{103} & \multirow{3}{*}{80} & \multirow{3}{*}{180} & 0 & 113 & 2 & 3.9 & 16.5 & $\begin{array}{r}7.8 \\
(100)\end{array}$ & $\begin{array}{r}13.5 \\
(100)\end{array}$ & $\begin{array}{r}17.6 \\
(100)\end{array}$ \\
\hline & & & 30 & 103 & 1 & 3.7 & 20.0 & $\begin{array}{r}5.7 \\
(73)\end{array}$ & $\begin{array}{r}9.5 \\
(71)\end{array}$ & $\begin{array}{l}11.8 \\
(67)\end{array}$ \\
\hline & & & 50 & 100 & 2 & 4.4 & 16.0 & $\begin{array}{r}4.5 \\
(74)\end{array}$ & $\begin{array}{r}7.0 \\
(52)\end{array}$ & $\begin{array}{r}9.3 \\
(53)\end{array}$ \\
\hline \multirow{3}{*}{102} & \multirow{3}{*}{80} & \multirow{3}{*}{180} & 0 & 118 & 3 & 4.0 & 21.3 & $\begin{array}{r}5.7 \\
(100)\end{array}$ & $\begin{array}{r}12.0 \\
(100)\end{array}$ & $\begin{array}{r}14.8 \\
(100)\end{array}$ \\
\hline & & & 20 & 112 & 3 & 4.1 & 18.6 & $\begin{array}{r}5.1 \\
(89)\end{array}$ & $\begin{array}{c}9.4 \\
(78)\end{array}$ & $\begin{array}{l}12.3 \\
(83)\end{array}$ \\
\hline & & & 30 & $110^{\circ}$ & 3 & 3.9 & 18.7 & $\begin{array}{c}4.2 \\
(74)\end{array}$ & $\begin{array}{r}8.0 \\
(67)\end{array}$ & $\begin{array}{l}10.8 \\
(73)\end{array}$ \\
\hline
\end{tabular}


$80 \mathrm{~mm}$ ，単位セメント・フライ アッシュ量を $180 \mathrm{~kg} / \mathrm{m}^{3}$ ，スランプを約 $3 \mathrm{~cm}$, 空気量を約 $4 \%$ としたダム用コンクリートについて, フライアッ シュオキカ工率を $0 \cdot 20 \cdot 30 \%$ とした場合（実験：102）

について，材令 7 日までその断熱温度上昇を測定した結果は，表一4・26 拉よび図一4・17 亿示すと杼りである。

すなわち, 中庸熱ポルトランド セメントの一部をフライ アッシュで掠 きかえたコンクリートの温度上昦は，フライ アッシュを用いない基準配 合のものに比して減少する。図一4・18 亿执いて, 材令 7 日飞扮ける温度上 昇を，基準配合のそれ対する百分率で表わし，これとフライアッシュ オキカエ率との関係を求めれば，実線のようになり，フライ アッシュの 扮きかえによる温度上景の減少率は，その才キカ土率飞比例し，オキカエ 率の約 90\% とみることができる。また，セメントの一部をフライ アッ シュで招きか党たセメントの材令 7 日に扮ける水和熱の，招きかえないも
図一4・17 フライ アッシュ を用いたコンクリートの 断熱渴度上界

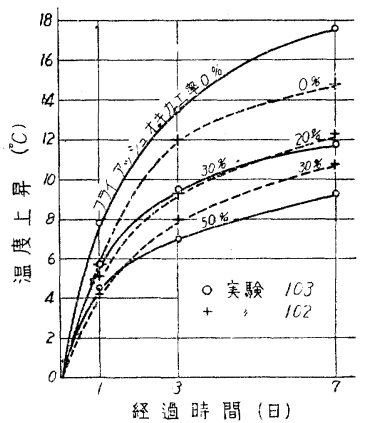

表一4・27 乾燥収縮試験のフライ アッシュを用いたコンクリートの配合

\begin{tabular}{|c|c|c|c|c|c|c|c|c|c|}
\hline \multicolumn{2}{|c|}{ 実験整理 } & \multirow{2}{*}{ 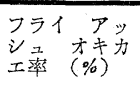 } & \multirow{2}{*}{ 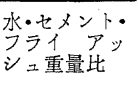 } & \multirow{2}{*}{$\begin{array}{c}\text { スンンプ } \\
(\mathrm{cm})\end{array}$} & \multirow{2}{*}{ 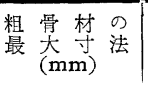 } & \multirow{2}{*}{ 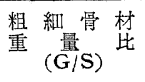 } & \multirow{2}{*}{$\begin{array}{l}\text { 単位セメント } \\
\text { 量 } \\
\left(\mathrm{kg} / \mathrm{m}^{3}\right)\end{array}$} & \multirow{2}{*}{$\begin{array}{l}\text { 単位フライ } \\
\text { ア翼 } \\
\left(\mathrm{kg} / \mathrm{m}^{3}\right)\end{array}$} & \multirow{2}{*}{$\begin{array}{c}\text { 単位水量 } \\
\left(\mathrm{kg} / \mathrm{m}^{3}\right)\end{array}$} \\
\hline 番 & 号 & & & & & & & & \\
\hline & \multirow{5}{*}{202} & 0 & 0.55 & 5 & 40 & 1.66 & 245 & 0 & 135 \\
\hline & & 10 & 0.55 & $"$ & $"$ & 1.66 & 220 & 25 & 134 \\
\hline & & 20 & 0.54 & " & " & 1.67 & 196 & 49 & 133 \\
\hline & & 30 & 0.53 & " & " & 1.68 & 171 & 74 & 129 \\
\hline & & 40 & 0.51 & $"$ & " & 1.69 & 147 & 98 & 123 \\
\hline & 考 & \multicolumn{8}{|c|}{ 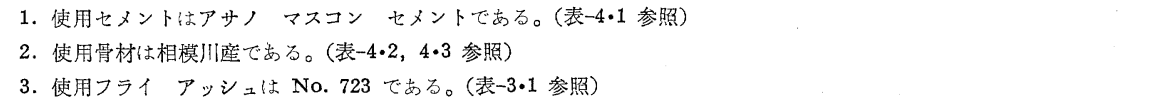 } \\
\hline
\end{tabular}

の飞対する百分率と,フライア ッシュオキカエ率との関係を 求めれば, 図一4.18の点線のよ うとなる(III〔3】12参照)。との 場合の水和熱の減少率は, フラ

図一4・18 フライ アッシュ オキカエ率と コンクリートの温度上昇およびセ メント水和熱との関係(材令 7 日)

イアッシュオキカエ率の約 80 \%とみることができる。このこ とから，セメントの一部をフラ イアッシュで括きかえたコンク リートの温度上昇の減少率は, 材令 7 日に括いてはフライア ッシュオキカエ率の 80 90\% と考光られる。材令 28 日法 ける断熱温度上景試験は行わな かつたが，材令 28 日に特ける セメントの水和熱の測定結果と 合わせて判断すれば，材令 28 日に和けるコンクリートの温度 上昇の減少率はフライアッシ ユオキカエ率の 70８0\%では ないかと推定される。
[1]フライ アッシュがコンクリートの乾燥収縮におよぼす影響

フライ アッシュでポルトランド セメントの, 0.10・20・30・40\%を括きかえて造つた表一4・27の配合のコ 
表一28 フライ アッシュ オキカエ率とそれを用いたコンクリート・ モルタル・ペーストの乾燥収縮

\begin{tabular}{|c|c|c|c|c|c|c|c|c|c|c|c|c|}
\hline \multirow{3}{*}{$\begin{array}{c}\text { フライ } \\
\text { ッン士 } \\
\text { キカ工率 } \\
(\%)\end{array}$} & \multicolumn{12}{|c|}{ 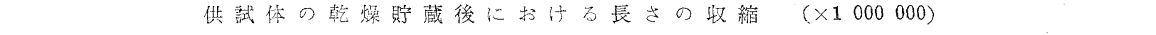 } \\
\hline & 3 & 日 & 7 & 日 & 14 & 日 & \multicolumn{2}{|c|}{28} & 日 & \multicolumn{2}{|c|}{50} & 日 \\
\hline & ペースト & モルタル & ペースト & モルタル & ペースト & モルタル & ペースト & モルタル & $\left\{\begin{array}{l}\text { コンクリ } \\
\text { ート }\end{array}\right.$ & ペースト & モルタル & 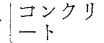 \\
\hline 0 & $\begin{array}{r}1710 \\
(100 \%)\end{array}$ & $\begin{array}{r}90 \\
(100 \%)\end{array}$ & $\begin{array}{r}2380 \\
(100 \%)\end{array}$ & $\begin{array}{r}200 \\
(100 \%)\end{array}$ & $\begin{array}{r}2600 \\
(100 \%)\end{array}$ & $\begin{array}{r}790 \\
(100 \%)\end{array}$ & $\begin{array}{r}2840 \\
(100 \%)\end{array}$ & $\begin{array}{r}1270 \\
(100 \%)\end{array}$ & $\begin{array}{r}380 \\
(100 \%)\end{array}$ & $\begin{array}{r}3150 \\
(100 \%)\end{array}$ & $\begin{array}{r}1400 \\
(100 \%)\end{array}$ & $\begin{array}{r}570 \\
(100 \%)\end{array}$ \\
\hline 10 & $\begin{array}{r}1610 \\
(94 \%)\end{array}$ & $\begin{array}{r}70 \\
(78 \%)\end{array}$ & $\begin{array}{r}2050 \\
(86 \%)\end{array}$ & $\begin{array}{r}190 \\
(95 \%)\end{array}$ & $\begin{array}{r}2290 \\
(88 \%)\end{array}$ & $\begin{array}{r}760 \\
(96 \%)\end{array}$ & $\begin{array}{r}2420 \\
(85 \%)\end{array}$ & $\begin{array}{r}1160 \\
(91 \%)\end{array}$ & $\begin{array}{r}330 \\
(87 \%)\end{array}$ & $\begin{array}{r}2640 \\
(84 \%)\end{array}$ & $\begin{array}{r}1230 \\
(88 \%)\end{array}$ & $\begin{array}{r}530 \\
(93 \%)\end{array}$ \\
\hline 20 & $\begin{array}{r}1540 \\
(90 \%)\end{array}$ & $\begin{array}{r}70 \\
(70 \%)\end{array}$ & $\begin{array}{r}1930 \\
(81 \%)\end{array}$ & $\begin{array}{r}180 \\
(90 \%)\end{array}$ & $\begin{array}{r}2070 \\
(80 \%)\end{array}$ & $\begin{array}{r}730 \\
(92 \%)\end{array}$ & $\begin{array}{r}2250 \\
(80 \%)\end{array}$ & $\begin{array}{r}1110 \\
(88 \%)\end{array}$ & $\begin{array}{r}310 \\
(82 \%)\end{array}$ & $\begin{array}{r}2400 \\
(76 \%)\end{array}$ & $\begin{array}{r}1190 \\
(85 \%)\end{array}$ & $\begin{array}{r}500 \\
(88 \%)\end{array}$ \\
\hline 30 & $\begin{array}{r}1440 \\
(84 \%)\end{array}$ & $\begin{array}{r}50 \\
(56 \%)\end{array}$ & $\begin{array}{r}1760 \\
(74 \%)\end{array}$ & $\begin{array}{r}170 \\
(85 \%)\end{array}$ & $\begin{array}{r}1880 \\
(72 \%)\end{array}$ & $\begin{array}{r}710 \\
(90 \%)\end{array}$ & $\begin{array}{r}2090 \\
(74 \%)\end{array}$ & $\begin{array}{r}990 \\
(78 \%)\end{array}$ & $\begin{array}{r}310 \\
(82 \%)\end{array}$ & $\begin{array}{r}2290 \\
(73 \%)\end{array}$ & $\begin{array}{r}1020 \\
(73 \%)\end{array}$ & $\begin{array}{r}480 \\
(84 \%)\end{array}$ \\
\hline 40 & $\begin{array}{r}1360 \\
(80 \%)\end{array}$ & $\begin{array}{r}50 \\
(56 \%)\end{array}$ & $\begin{array}{r}1630 \\
(69 \%)\end{array}$ & $\begin{array}{r}150 \\
(75 \%)\end{array}$ & $\begin{array}{r}1810 \\
(70 \%)\end{array}$ & $\begin{array}{r}660 \\
(84 \%)\end{array}$ & $\begin{array}{r}2.040 \\
(72 \%)\end{array}$ & $\begin{array}{r}960 \\
(76 \%)\end{array}$ & $\begin{array}{r}310 \\
(82 \%)\end{array}$ & $\begin{array}{r}2260 \\
(72 \%)\end{array}$ & $\begin{array}{r}1010 \\
(72 \%)\end{array}$ & $\begin{array}{r}460 \\
(81 \%)\end{array}$ \\
\hline
\end{tabular}

備考 各測定值は供試体 3 個の平均値でるる。

ンクリートについて試験を行つた結果は, 表一4・

28 呿よび図一4.19 亿示すと抒りである。表一4・

28 和よび図一4.19 から次のことが認められる。

(i) フライ アッシュでポルトランド セメン トの一部起招きか光た場合，コンクリートの翰燥 収縮は，フライ アッシュを用いないものにくら べて減少する。

(ii) この減少の程度は, 材令によつて多少の 相違はあるが，フライ アッシュオキカエ率が増 加するのに応じて大きくなる傾向が認められる。 フライ アッシュ オキカエ率40\%の場合, 約 $20 \%$ 弱減少した。

(iii) フライ アッシュでポルトランド セメン 卜の一部を称きか光它モルタル招よびペーストに ついても同様の傾向が諗められる。
図-4.19 フライ アッシュがコンクリート， モルタルおよびペーストの乾燥収縮 におよぼす影響

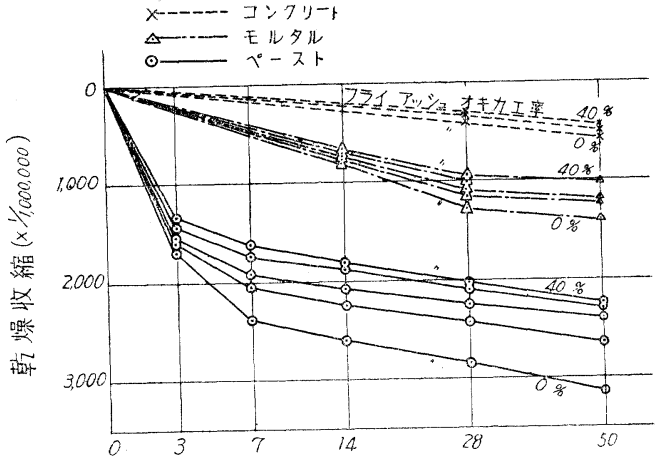

乾爆日 数 (日)

\section{V. ポ゙ド アッシュおよびサイクロン系フライ アッシュの粉碎利用に関する試験}

\section{[1]概説}

わが国現有の火力発電所々は，設備費括よび維持費のかかるコットレル集麿器を設備するものが少い。電源開 発 5 カ年計画ならびに上水・治水・かんがいなどの多目的開発計画などにみるわが国のダムの建設計画を考光る ときむしこれらにフライ アッシュを使うとしてコットレル系のもののみを対象とするならば，中程度のダム が 2〜3 程度しか子かない得ないととになる。

またコットレル系の良質のフライアッシュは，午の特長が高く評価されるようになつたプレパクトコンクリ 一ト用ならでに防水コンクリート用，さらにコンクリートブロック用として，その使用分野を急速飞開拓しつ つある。

こ扎らの点より，本試験研究の当初から，コットレル系フライアッシュの需給のバランスは近々に破れるこ とを想定し，かつ一方廃䢂物である各種アッシュの資源化ないし有効利用の立場より，ポンドアッシュ，サイ クロン系アッシュを粉砕し，これをポゾラン混和材として利用する問題について重点的に試験を進めてきた。も らろん，サイクロン采フライアッシュに対しては，その粉砕利用とに別に，粗粒子群を筫別によつて除き，微 椟子群のみとして利用することも考光られるが，との歩止りの閭題走別としても，サイクロン系フライアッシ

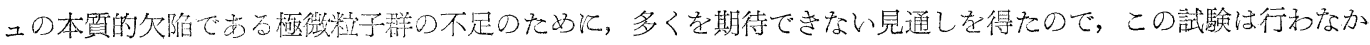
つた。

ポンドアッシュ，サイクロン系フライアッシュの粉轨利用を問題にする場合，それらの粉研アッシュといわ ゆるフライアッシュの粘子形状を比較し，コンクリートのウォーカビりチー改善の点で前者が後者に步るとと 
を実験的手段によらないで論じ，粉䂥利用の不可を結論するのは当を得たものでない。むしこれを不可とするな らば, それは粉砕アッシュとコットレル系フライ アッシュのコンクリートの性質におよぼす影響を実験的に比 較し，さらにはフライ アッシュ以外の他のポゾラン混和材と比較してみなければならない。

以下，ポンドアッシュ怙よびサイクロン系フライ アッシュの粉砕利用に関する試験について述べ，それらの 粉伜アッシュがポゾラン混和材としてきわめて有用であることを明らかにする。

\section{〔2] ポンド アッシュの粉砕利用に関する試験}

1. ポンドアッシュの化学成分ならびに物理的性質

（1）ポンドアッシュ：試験用いたポンドアッシュは，尼ケ崎第二火力発電所のアッシュ ポンドより採取 したものである。試料ポンド アッシュは，その粒の大きさによつて A (0.5 mm 以下)， B (0.5 10 mm) 特よ び C (10 mm 以上)の 3 種類に分け，乾燥後試験ミルで粉砕して用いた。これらのポンドアッシュの括をな性 質は 表一5.1 と示すと扰りである。

表一5・1 試験に用いた粉研ポンド アッシュのお敞な性質

\begin{tabular}{|c|c|c|c|c|c|c|c|c|c|c|c|c|c|}
\hline \multirow[b]{2}{*}{ 区 } & \multirow[b]{2}{*}{ 分 } & \multicolumn{3}{|c|}{ 化 } & 学 & 成 & 分 & \multicolumn{3}{|l|}{$(\%)$} & \multirow[b]{2}{*}{ 比重 } & \multicolumn{2}{|c|}{ 粉 末 度 } \\
\hline & & $\begin{array}{l}\text { ンリカ } \\
\left(\mathrm{SiO}_{2}\right) \\
\end{array}$ & $\begin{array}{l}\text { アルミナ } \\
\left(\mathrm{Al}_{2} \mathrm{O}_{3}\right)\end{array}$ & $\begin{array}{l}\text { 酸化鉄 } \\
\left(\mathrm{Fe}_{2} \mathrm{O}_{3}\right)\end{array}$ & \begin{tabular}{|l|}
$\mid \begin{array}{c}\text { 酸化カル } \\
\text { シウム } \\
(\mathrm{CaO})\end{array}$ \\
\end{tabular} & $\begin{array}{l}\text { マアクネン } \\
\text { P } \\
(\mathrm{MgO})\end{array}$ & $\left|\begin{array}{c}\text { 無水硫酸 } \\
\left(\mathrm{SO}_{3}\right)\end{array}\right|$ & $\begin{array}{l}\text { 茏素 } \\
\text { (C) }\end{array}$ & 強熱減量 & 合 計 & & $\left|\begin{array}{c}88 \mu フ ル 1 \\
\text { 残分 }(\%)\end{array}\right|$ & $\begin{array}{l}\text { プレーン } \\
\text { 比表面積 } \\
\left(\mathrm{cm}^{2} / \mathrm{g}\right)\end{array}$ \\
\hline ポンド アッン & $\prime=A$ & 57.1 & 27.0 & 5.0 & 4.3 & 2.1 & 0.8 & 1.4 & 3.1 & 99.4 & 2.40 & 1.5 & 2870 \\
\hline " & B & 56.3 & 25.8 & 6.0 & 6.5 & 2.2 & 0.7 & 1.0 & 1.9 & 99.4 & 2.51 & 1.5 & 3240 \\
\hline " & C & 57.4 & 28.2 & 4.8 & 4.9 & 1.9 & 0.4 & 1.1 & 1.1 & 98.7 & 2.53 & 1.1 & 3410 \\
\hline $\begin{array}{l}\text { 尼ケ崎フライ ア } \\
8 \text { 種の平均 * }\end{array}$ & アッンュ & 54.5 & 29.4 & 5.9 & 3.5 & 1.7 & 0.7 & 1.2 & 2.3 & 99.2 & 2.14 & 1.4 & 4350 \\
\hline
\end{tabular}

* 表-3,1 参照

（2）粉砕ポンド アッシュの化学成分・比重・粉末度 : 表一5・1 より次のことが認められる。

（i） ポンド アッシュの化学成分は，フライ アッシュとほぼ同じである。このととは，クリンカ アッシュ・ ピットアッシュ括よびフライ アッシュの捕集される場所が相異しても，その根源が同一であることを考光れば 当然である。従つてその化学成分からみた場合, ポンド アッシュはコットレル系フライ アッシュと同様に, ポ ゾラン混和材として十分に利用しうる成分を有するものといえる。

(ii) 粉砕ポンド アッシュの比重は, 3 種とも 2.5 前後であつて, コットレル系フライ アッシュの比重が, 2.1 前後であるのにくらべて相当に大きい。これは前にも述べたようにアッシュ粉砕の影響も加わるものと考克 られる。

（iii）試験に用いた粉伜ポンド アッシュの粉末度は，大体に招いてポルトランド セメントと同程度とした。 この場合，粉砕ポンド アッシュのうちには，粉砕という過程にもかかわらず，な持球状粒子が相当に存在する ことが認められた（写真一5・1）。これは，ポンド アッシュのうちには，いわゆる微細な球状のフライ アッシュ も相当含まれていて，これのあるものは，直接の粉砕をうけずにそのまま残るためであると考学られる。

（3）粉砕ポンド アッシュのポゾラン活性：III〔2〕5 で述べた石灰ポゾラン砂モルタル強度試験方法に従い,

表一5.2 ポンド アッシュの石灰・ポゾラ ン砂モルタル試騟結果

\begin{tabular}{|c|c|c|c|}
\hline 試 & $\begin{array}{l}\text { モルタル中 } \\
\text { の水量 }(\%)\end{array}$ & 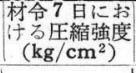 & 強度の比 \\
\hline ポンド アッンュ $\mathbf{A}$ & 12.5 & 60.6 & 1.03 \\
\hline $\mathrm{B}$ & 12.3 & 61.2 & 1.04 \\
\hline C & 12.6 & 66.8 & 1.14 \\
\hline フライ アッンュN & 12.8 & 58.6 & 1.00 \\
\hline 市販 湿和材 $\mathbf{A}$ & 14.3 & 47.9 & 0.82 \\
\hline B & 20.7 & 46.2 & 0.79 \\
\hline
\end{tabular}

诵考
1. 砂は Ottawa 標準砂を用いた。

2. U.S.B.R 規格: $\sigma_{7}>42.2 \mathrm{~kg} / \mathrm{cm}^{2}$
写真一5.1 粉砕したポンド アッシュの顕微鏡写真

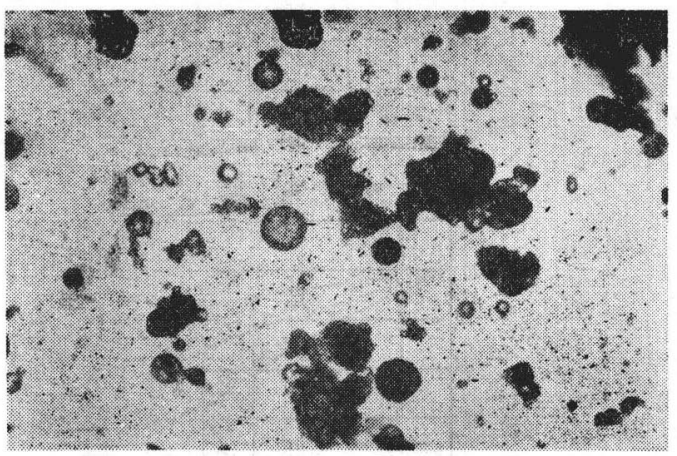


前記 3 種のポンド アッシュ执よびそれと比較する目的で，コットレル系フライアッシュN，市販混和材 $A ， B$ そついて，そのポゾラン活性を試験した結果は，表一5.2 と示すと䄧りであつた。

表一5・3 セメント・ポンド アッシュ・砂モルタル強度試験結果

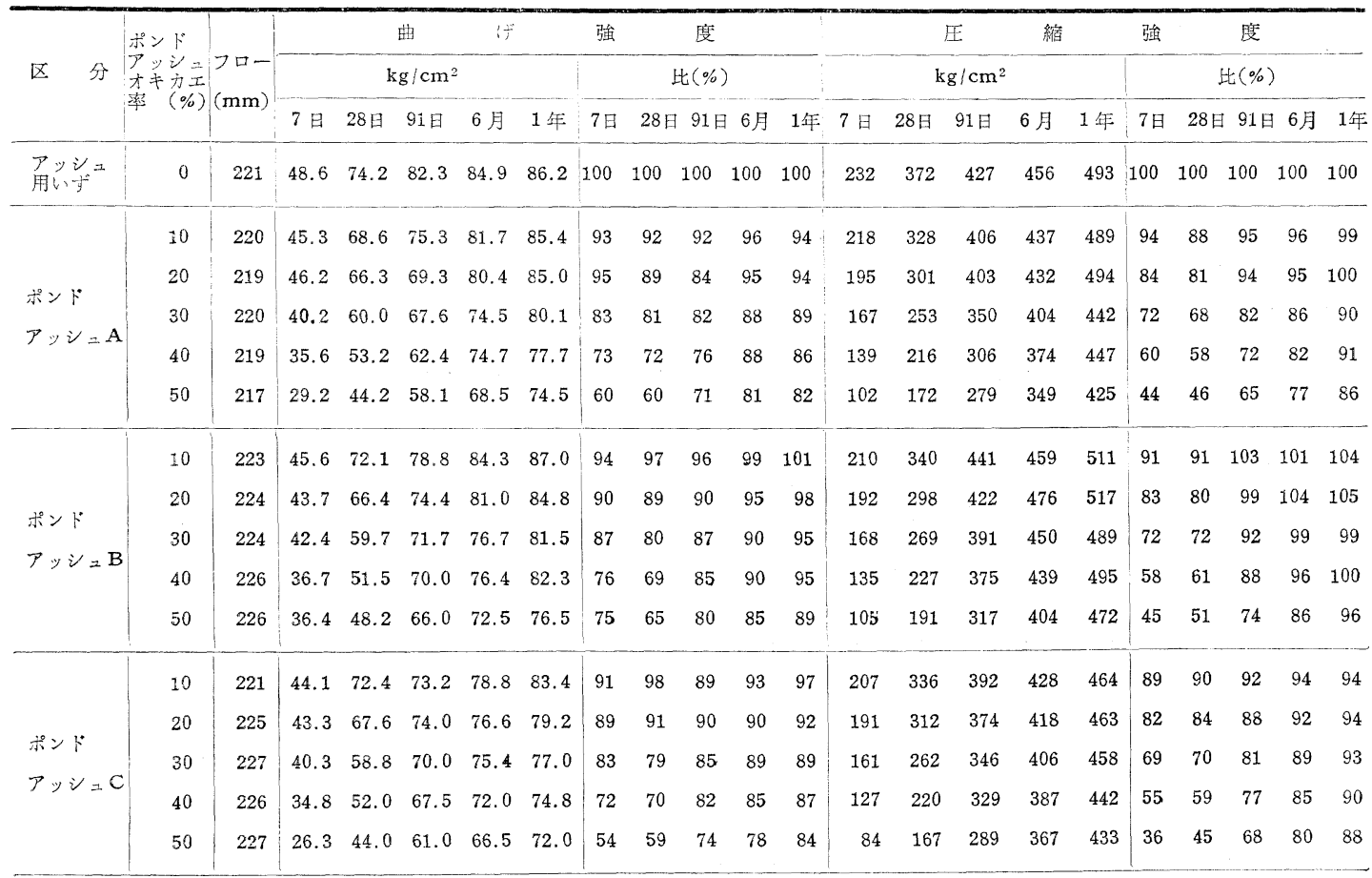

図一5.1 ポンド アッシュ オキカエ率とモ ルタル強度との関係 セメント：大 陙突業普通ポルトランドセメント

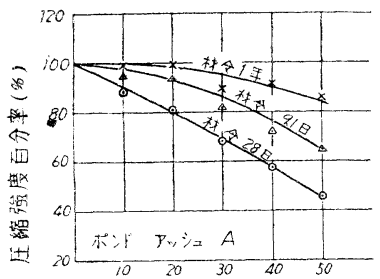

ホントアアジオキ力工率(\%)

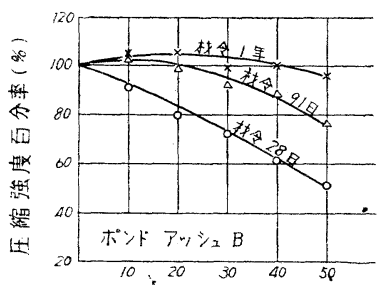

ポンドッシュオキカ变 $(\%$

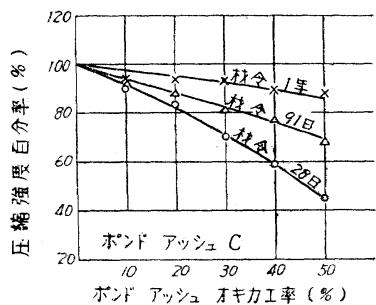

表一5・4 市販混和材を用いた 標準モルタルのフロー

\begin{tabular}{|c|c|c|}
\hline \multirow{2}{*}{$\begin{array}{l}\text { 淈和材才 } \\
\neq \text { 力工恝 } \\
(\%)\end{array}$} & \multicolumn{2}{|c|}{ モルタルのフフロー $(\mathrm{mm}$} \\
\hline & 混和材 A & 混和材 B \\
\hline 0 & 189 & 189 \\
\hline 10 & 164 & 178 \\
\hline 20 & 129 & 163 \\
\hline 30 & 120 & 148 \\
\hline 40 & 113 & 127 \\
\hline 50 & 108 & 116 \\
\hline
\end{tabular}

表一5.5 ポンド アッシュ セメ ント砂モルタルの 1 年強 度亡 28 日強度との此

\begin{tabular}{c|c|c|c}
\hline \multirow{2}{*}{$\begin{array}{c}\text { ポンド アッシュ } \\
\text { オキカエ率 }\end{array}$} & \multicolumn{3}{|c|}{ ポント } \\
\cline { 2 - 4 } & $\mathrm{A}$ & $\mathrm{B}$ & $\mathrm{C}$ \\
\hline 0 & 1.3 & 1.3 & 1.3 \\
\hline 10 & 1.5 & 1.5 & 1.4 \\
\hline 20 & 1.6 & 1.7 & 1.5 \\
\hline 30 & 1.8 & 1.8 & 1.8 \\
\hline 40 & 2.1 & 2.2 & 2.0 \\
\hline 50 & 2.5 & 2.5 & 2.6 \\
\hline
\end{tabular}


表一5・2より次のことが認められる。

3 種の粉砕ポンド アッシュで造つた石灰モルタルの材令 7 日強度はそれぞれ $60.6 \cdot 61.2 \cdot 66.8 \mathrm{~kg} / \mathrm{cm}^{2}$ となつ ていて U.S.B.R. 規格の $42.2 \mathrm{~kg} / \mathrm{cm}^{2}$ をはるか火上迴つて挌り，粉砕ポンド アッシュのポゾラン活性は十分 满足しうるものである。これらのポンドアッシュを用いた石灰モルタルの強度を, コットレル系フライアッシ ュのうちでも良質の部類に属するフライ アッシュN飞対する比で示すとそれぞれ $1.03 \cdot 1.04 ・ 1.14$ となつて， 粉伜ポンド アッシュがコットレル系フライアッシュにまさるとも少らぬポゾラン活性を有することが認められ る。な扔粉砕ポンドアッシュが市販混和材 A・B とくらべて数段すぐれたポゾラン活性を有することは注目す べき事実である。

2. ポンドアッシュがモルタルのコンシステンシー特よび強度に招よぼす影響 表一5・1 亿示す粉砕ポンド アッシュと，大阪䇺業K K 普通ポルトランド セメントを用いて，粉砕ポンド アッシュでセメントの重量の 10 . $20 \cdot 30$ ・ 40 ・50\%を打きかえた混和物を一種のセメントとみなし, JIS R 5201 (セメントの物理試験方法) に従 い,フロー試験和よび強度試験を行つた結果は 表一5.3 抢よび 図一5.1 と示すと和りであつた。

表一5.3 招よび 図一5.1 より次のことが認められる。

（i） 使用水量を一定とした場合，ポンド アッシュを用いたモルタルのフローはポンド アッシュオキカエ 率が増加してもほとんど変化しない。このことから，粉砕ポンド アッシュでセメントの一部を掠きかえてコン クリートを造る場合，その使用水量を増加する必要のないととが期待できる。ついでながら，表一5.4 と示すよ

表一5.6 混合ポルトランド セメントの試験結果の一例

\begin{tabular}{|c|c|c|c|c|c|}
\hline 区 & 分 & $\begin{array}{l}\text { 混合ポルトランド } \\
\text { セメント(40\%混合) }\end{array}$ & $\begin{array}{l}\text { 普通ポルトラン } \\
\text { ドメント }\end{array}$ & $\begin{array}{c}\text { JIS } \\
\text { 中揵熱規格 }\end{array}$ & $\begin{array}{l}\text { JIS } \\
\text { 普通規格 }\end{array}$ \\
\hline \multirow{9}{*}{ 化 学 成 分 $(\%)$} & 強 熱 減 量 & 1.4 & 0.64 & $<4.0$ & $<4.0$ \\
\hline & 不＼cjkstart溶 & 29.3 & 0.90 & & \\
\hline & ン リ カ $\left(\mathrm{SiO}_{2}\right)$ & 16.0 & 21.48 & & \\
\hline & $ア ル ミ ナ\left(\mathrm{Al}_{2} \mathrm{O}_{3}\right)$ & 4.2 & 5.56 & & \\
\hline & 酸化第二鉄 $\left(\mathrm{Fe}_{2} \mathrm{O}_{3}\right)$ & 3.4 & 3.16 & & \\
\hline & 酸化カルシウム（CaO) & 42.2 & 64.64 & & \\
\hline & マグネンア (MgO) & 0.9 & 1.18 & $<4.0$ & $<5.0$ \\
\hline & 無 水硫酸 $\left(\mathrm{SO}_{3}\right)$ & 2.0 & 1.85 & $<2.5$ & $<2.5$ \\
\hline & 合＼cjkstart計 & 99.4 & 99.41 & & \\
\hline 比 & 重 & 2.95 & 3.15 & $>3.05$ & $>3.05$ \\
\hline 末 & 度 $(0.088)$ & 2.1 & 2.0 & $<10.0$ & $<10.0$ \\
\hline & 量（\%) & 27.5 & 26.2 & & \\
\hline & 発(時一分) & $2-11$ & $1-35$ & $>1$ & $>1$ \\
\hline 凝 & 結 (") & $4-44$ & $3-10$ & $<10$ & $<10$ \\
\hline & 度 $\left({ }^{\circ} \mathrm{C}\right)$ & 21.0 & 21.0 & $20 \pm 3$ & $20 \pm 3$ \\
\hline & 湿 度 $(\%)$ & 85 & 85 & & \\
\hline 口 & $-(\mathrm{mm})$ & 216 & 213 & & \\
\hline \multirow{3}{*}{ 曲ゲ強度 $\quad\left(\mathrm{kg} / \mathrm{cm}^{2}\right)$} & 日 & 23.7 & 28.5 & $>10$ & $>12$ \\
\hline & 日 & 34.8 & 49.7 & $>20$ & $>25$ \\
\hline & 28 & 53.5 & 70.5 & $>30$ & $>36$ \\
\hline \multirow{3}{*}{ 圧縮强度 $\left(\mathrm{kg} / \mathrm{cm}^{2}\right)$} & 日 & 64 & 102 & $>35$ & $>45$ \\
\hline & 日 & 113 & 188 & $>70$ & $>90$ \\
\hline & 28 & 203 & 340 & $>150$ & $>200$ \\
\hline \multirow{3}{*}{ 養 生 水 温 $\left({ }^{\circ} \mathrm{C}\right)$} & 日 & 21.3 & 21.5 & $20 \pm 3$ & $20 \pm 3$ \\
\hline & 日 & 20.8 & 20.9 & $"$ & $"$ \\
\hline & 28 & 21.6 & 20.8 & $"$ & 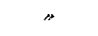 \\
\hline
\end{tabular}


う飞市販混和材 A・Bでは，フローがそのオキカエ率飞比例して減少している（表一5·4）。

(ii） 粉伜ポンド アッシュを用いたモルタルの強度は, ポンドアッシュ A・B・Cによつて多少の差はある が，早期材令に和いては，ポンドアッシュを用いないものより，ポンド アッシュオキカエ率にほぼ比例して小 さく，材令の増加とともに急速に回復し，コットレル系フライ アッシュと同じ傾向にあることが認められる。

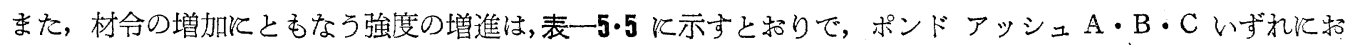
いてもほぼ同様つ值であり,ポンド アッシュオキカエ率が大きいものほど大きい。以上のことから，ポンドア ッシュとして A・B・Cを分けないものを粉砕して用いても，上記の性質を期待してよいと考えられる。

3. ポンドアッシュを用いた混合ポルトランドセメントの製造とその試験結果の一例 以上の試験結果から 粉砕ポンド アッシュのポゾラン混和材としての有用性を確かめたので,さらにポンド アッシュが粉末のものよ り塊状のものまでの混和物であることを考虑して,これの粉砕はセメントクリンカとともに行つて，粉砕過程を 集結するとともに，均一な混合物をうることが有利であるという結論をえた。すなわちポントアッシュを乾燥 処理し，これとポルトランド セメントクリンカと混合同時粉砕して混合ポルトランド セメントを製造した。 ポンド アッシュ混合率を 40\% とした混合ポルトランド セメントに関する二, 三の試験結果を示せば次のと和 りである。

(1) 混合ポルトランド セメントの JIS 規格による試験結果 : ポンド アッシュ混合率 $40 \%$ の混合ポルトラン ド セメントを JIS R 5201 (セメントの物理試験方法) および同 5202 (セメントの化学分析方法) に従つて試験 した結果は 表一5.6 亿示すと怙りである。

この試験結果によれば，混合ポルトランド セメントの化学成分は，不溶残分を除けば中庸熱または低熱ポル トランド セメントに近いものである。この不溶残分が多いのは，ポンドアッシュの塩酸では溶けない部分によ るものであつて，ポンドアッシュのアルカリ溶ゆう方法による表一5・1の結果より判断すれば，これは支障のな いものと考光られる。また, 比重は 2.95 であつて普通ポルトランドセメントよりも多少小さいが, 粉末度は, $0.088 \mathrm{~mm}$ フルイ残分で $2.1 \%$ であるから, 普通ポルトランド セメントと大体同じ程度に粉砕されうるものと考 えられる。また, 混合ポルトランド セメントの強度は, 粉砕ポンド アッシュを用いた表一5・3の試験結果と同 じ傾向にあることが認められる。

(2) 混合ポルトランド セメントを用いたコンクリートに関する試験結果 : ポンド アッシュ混合率 $40 \%$ の混 合ポルトランドセメントを用い,

（i）粗骨材最大寸法 $25 \mathrm{~mm}$ ，水セメント重量比をそれぞれ $0.52 \cdot 0.57 \cdot 0.62$ ，スランプを約 $7 \mathrm{~cm}$ としたコ ンクリート,

（ii）粗骨材最大寸法 $30 \mathrm{~mm}$ ，水セメント重量比をそれぞれ $0.52 \cdot 0.74$ ，スランプをそれぞれ $6 \mathrm{~cm} 2 \mathrm{~cm}$ としたコンクリート,

を $20^{\circ} \mathrm{C}$ 水中養生を行い，圧縮強度を試験した結果を表一5・7 亿示す。表一5.7 括よ゙ 表一4・14 の奏験： 011 (単位セメント量 $285 \mathrm{~kg} / \mathrm{m}^{3}$ ) から, コンクリートの材令と圧縮強度との関係を図示したものを図一5・2 す。季た, 表一5.7 挔よび実験: 011 から, コンクリートのセメント水重量比と材令 28 日強度との関係を図示 したものを図一5・3 に示す。

すなわち，混合ポルトランド セメントを用いたコンクリートの材令の増加にともなう強度の増進状態は，フ

表一5.7 混合ポルトランド セメントを用いたコンクリートの強度

\begin{tabular}{|c|c|c|c|c|c|c|c|c|c|c|c|c|}
\hline \multirow{2}{*}{ 七 } & \multirow{2}{*}{$x$} & \multirow{2}{*}{ ン } & \multirow{2}{*}{$\begin{array}{c}\text { 粗骨材の } \\
\text { 最大寸法 } \\
(\mathrm{mm})\end{array}$} & \multirow{2}{*}{$\begin{array}{c}\text { 水セメント } \\
\text { 重量比 }\end{array}$} & \multirow{2}{*}{$\begin{array}{l}\text { 単 位 } \\
\text { セメント量 } \\
\left(\mathrm{kg} / \mathrm{m}^{3}\right)\end{array}$} & \multirow{2}{*}{$\begin{array}{l}\text { 単 位 } \\
\text { 水 量 } \\
\left(\mathrm{kg} / \mathrm{m}^{3}\right)\end{array}$} & \multirow{2}{*}{\begin{tabular}{|l} 
粗細骨材 \\
重量比
\end{tabular}} & \multirow{2}{*}{$\mid \begin{array}{c}\text { スランプ } \\
(\mathrm{cm})\end{array}$} & \multicolumn{4}{|c|}{ 圧縮 強度 $\left(\mathrm{kg} / \mathrm{cm}^{2}\right)$} \\
\hline & & & & & & & & & 7 日 & 28日 & 91日 & 20 月 \\
\hline \multirow{3}{*}{\multicolumn{3}{|c|}{$\begin{array}{l}\text { 混合ポルトランド } \\
\text { セメント } \\
\quad(\text { P.A. }=40 \%)\end{array}$}} & \multirow{3}{*}{25} & & 346 & 180 & 1.22 & 5 & 98 & 171 & 262 & 315 \\
\hline & & & & 0.57 & 322 & 184 & 1.21 & 7 & 85 & 147 & 219 & 290 \\
\hline & & & & 0.62 & 299 & 185 & 1.18 & 7 & 70 & 125 & 184 & 275 \\
\hline \multirow{2}{*}{\multicolumn{3}{|c|}{$\begin{array}{l}\text { 普通ポルトランド } \\
\text { セメント }\end{array}$}} & \multirow{2}{*}{30} & 0.52 & 354 & \multirow{2}{*}{177} & 1.4 & 6 & - & 210 & - & - \\
\hline & & & & 0.74 & 239 & & 1.2 & 2 & - & 85 & - & - \\
\hline
\end{tabular}

2. 試験值は供試体 3 4 個の試験值の平均值である。 
ライアッシュを用いたコンクリートのそれとほ ぼ同じである。水セメント重量比が同じ場合注， 混合ポルトランド セメントを用いたコンクリー トの強度は, 早期材令に招いては普通ポルトラン ドセメントを用いたコンクリートよりも弱いが, 長期材令に括いては後者とほぼ同じ程度である。 な扮, コンクリートの練り混ぜそ当つて, 混合ポ ルトランド セメントを用いたコンクリートは， 普通ポルトランド セメントを用いたコンクりー トにくらべてプラスチシチーならびにウォ一カ ビリチーがいちじるしくよくなることが認められ た。

[3]サイクロン系フライ アッシュの粉 砕 利 用に関する試騃

1. サイクロン系フライアッシュの化学成分 ならびに物理的性質

（1）サイクロン系フライアッシュ：試験汇用 いたサイクロン系フライ アッシュは，尼ケ崎第 二火力発電所 10 号缶招よび 11 号缶マルテ サイク ロン集麿器より採取したもの 4 種, 飾磨港火力発 電所シングル サイクロン集塵器より採取したも の 2 種である。これらの試験用いたフライア ッシュは，その前後に採取したフライアッシュ
図一5.2 混合ポルトランド セメントを用いたコ ンクリートの圧縮強度

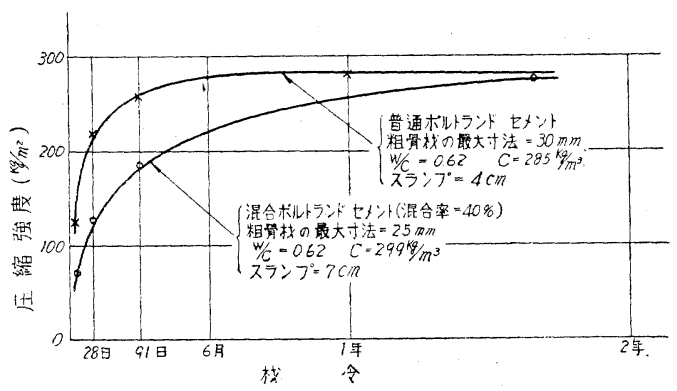

図一5.3 セメント・フライ アッシュ水重量比と 材令 28 日圧縮強度之の関係

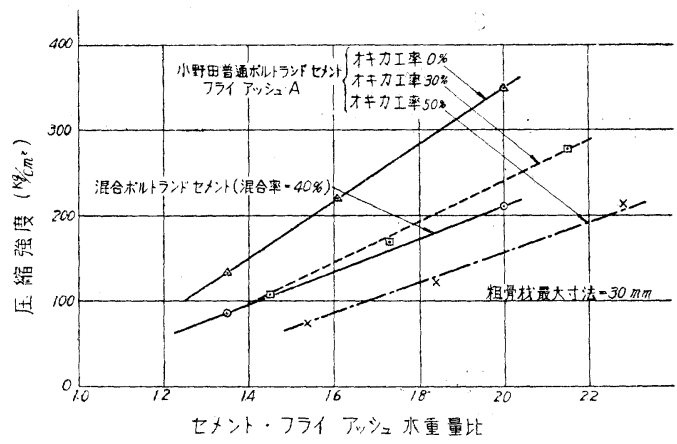

の品質の範团から考光て，それぞれの代表的試料とみなすととができるむのである。これらのサイクロン系フラ イアッシュの和もな性質は，表一5・8 亿示すと括りである。

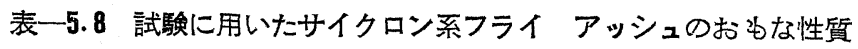

\begin{tabular}{|c|c|c|c|c|c|c|c|c|c|c|c|c|c|c|c|}
\hline \multirow[b]{2}{*}{ 区 } & \multirow[b]{2}{*}{ 採取個衣 } & \multicolumn{3}{|c|}{ 化 } & 成 & \multicolumn{5}{|c|}{ 分 $(\%)$} & \multirow[b]{2}{*}{ 比重 } & \multicolumn{2}{|r|}{ 粉 } & \multicolumn{2}{|c|}{ 度 } \\
\hline & & $\begin{array}{l}\text { シリカ } \\
\left(\mathrm{SiO}_{2}\right) \\
\end{array}$ & $\begin{array}{l}P ル ミ ナ \\
\left(\mathrm{Al}_{2} \mathrm{O}_{3}\right)\end{array}$ & $\begin{array}{l}\text { 酸化鉄 } \\
\left(\mathrm{Fe}_{2} \mathrm{O}_{3}\right)\end{array}$ & $\begin{array}{l}\text { 酸化カル } \\
\text { シウム } \\
(\mathrm{CaO})\end{array}$ & $\begin{array}{l}\text { マゲネシ } \\
\text { ア } \\
(\mathrm{MgO})\end{array}$ & $\left|\begin{array}{c}\text { 無水 } \\
\text { 硫酸 } \\
\left(\mathrm{SO}_{3}\right)\end{array}\right|$ & $\begin{array}{l}\text { 炭委 } \\
\text { (C) }\end{array}$ & $\begin{array}{l}\text { 強熱 } \\
\text { 減基 }\end{array}$ & 合計 & & $\begin{array}{l}88 \mu \text { フル } \\
1 \\
\text { 残分 }(\%)\end{array}$ & $\mid \begin{array}{l}44 \mu>ル \\
1 \\
\text { 残分 }(\%)\end{array}$ & $\begin{array}{l}\text { ブレーン } \\
\text { 比表面積 } \\
\left(\mathrm{cm}^{2} / \mathrm{g}\right)\end{array}$ & $\begin{array}{l}\text { 此重計: } \\
\text { 法によ。 } \\
\text { 比表面: } \\
\left(\mathrm{cm}^{2} / \mathrm{s}\right.\end{array}$ \\
\hline No. 311 & 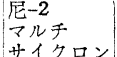 & 55.4 & 27.0 & 5.0 & 4.2 & 1.4 & 0.5 & 4.5 & 5.0 & 98.5 & 2.03 & 7.9 & 31.0 & 2930 & 1381 \\
\hline No. 312 & " & 57.8 & 28.4 & 4.6 & 4.3 & 0.7 & $\operatorname{tr}$ & 3.0 & 3.2 & 99.0 & 1.97 & 15.8 & 53.0 & 2000 & 97 \\
\hline No. 330 & $"$ & 58.8 & 24.0 & 6.5 & 4.8 & 2.3 & 0.3 & 1.7 & 1.9 & 98.6 & 2.01 & 8.8 & 33.9 & 1800 & 1521 \\
\hline No. 45 & 飾磨” & 55.0 & 26.7 & 6.7 & 5.5 & 2.0 & 0.5 & 2.4 & 2.6 & 99.0 & 2.05 & 7.2 & 29.2 & 2160 & 181 \\
\hline $\mathrm{s}$ & $\begin{array}{l}\text { ンングル } \\
\text { サイクロン }\end{array}$ & 46.9 & 20.2 & 10.5 & 6.6 & 1.9 & 3.7 & 4.7 & 8.1 & 97.9 & 2.08 & 22.9 & 67.0 & 2160 & 64 \\
\hline $\begin{array}{c}\mathrm{S}_{1} \\
\text { 尼ケ崎フライ }\end{array}$ & " & 54.5 & 26.2 & 7.9 & 3.0 & 1.4 & 0.6 & 4.5 & 6.1 & 99.7 & 1.96 & 30.0 & 72.4 & 1330 & 80 \\
\hline $\begin{array}{l}\text { アッジ } \\
18 \text { 種の平均 }\end{array}$ & $\left|\begin{array}{l}\epsilon^{-2} \\
\exists ッ \vee レ\end{array}\right|$ & 56.4 & 28.0 & 6.2 & 3.7 & 2.0 & 0.6 & 1.5 & 2.2 & 100.6 & 2.13 & 2.2 & 12.9 & 4090 & 303 \\
\hline
\end{tabular}

（2）サイクロン系フライ アッシュの化学成分，比重和よび粉末度：表一5.8より次のととが認められる。

(i) 同一火力発電所のフライアッシュについてい党ば, サイクロン系フライ アッシュの化学成分は, コッ トレル系フライ アッシュ括よびポンド アッシュとほぼ同様である。従つて化学成分からみた場合には，サイク ロン系フライ アッシュもポゾラン混和材として十分利用しうる成分を有するものといえる。

(ii） サイクロン系フライアッシュの比重は，全般的にいって，コットレル系フライ アッシュにくらべてや や小さい。このことは同一条件で生成されたフライアッシュでは，粗粒子群に掠けるほどその比重が小さくな

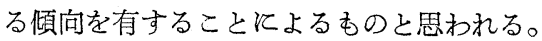

(iii）一般にサイクロン系フライアッシュの粉末度は，コットレル系フライアッシュにくらべて相当粗い。 尼ケ崎第二火力発電所産のアッシュを例飞とると, サイクロン系フライアッシュの粉末度は, $88 \mu フ ル イ$ 残分

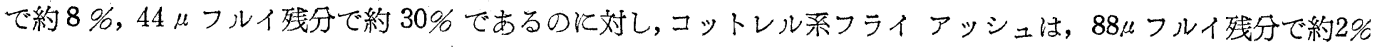


$44 \mu$ フルイ残分で $13 \%$ であつて, 両者の間には相当の差異が認められる。また同じサイクロン系フライアッ シュでも，その集塵器の型によつてフライ アッシュの粉末度が相違することは当然であつて，表一5.8 とおい てマルチ サイクロン集塵器で採取した尼ケ崎フライ アッシュと,シングル サイクロン集蚍器で採取した飾磨フ ライアッシュとの粉末度のいちじるしい相違は，その一例である。

なお，粉末度としてのブレーン比表面積は，サイクロン系フライ アッシュに関するかぎり，直接のめやすと なり得ない。試験に用いた 6 種のサイクロン系フライ アッシュについて，ブレーン方法扮よび比重計方法によ る比表面積を,フライ アッシュNo. 312 飞対する比で示すと次のと扮りである。

$\begin{array}{lcr} & \text { ブレーン方法 } & \text { 比重計力 } \\ \text { No. } 311 & 1.46 & 1.42 \\ \text { No. } 312 & 1.00 & 1.00 \\ \text { No. } 330 & 0.90 & 1.57 \\ \text { No. } 45 & 1.08 & 1.87 \\ \mathrm{~S} & 1.08 & 0.66 \\ \mathrm{~S}_{1} & 0.67 & 0.83\end{array}$

すなわち，粉末度の細粗の序列は，ブレーン方法による場合と，比重計方法による場合とでいちじるしく相違 し，サイクロン系フライ アッシュに対しては，ブレーン方法が必ずしも粉末度のめやすとなり得ないととがわ かる。とれは，サイクロン系フライアッシュの粉末度が比較的粗いために，ブレーン方法を適用するのが妥当 でないととによるものと思われる。

表一5.9 サイクロン系フライ アッシュの石 灰ポゾラン砂モルタル試験および所 要水量比

\begin{tabular}{|c|c|c|c|c|}
\hline 料 & $\begin{array}{c}\text { 所要水量比 } \\
(\%)\end{array}$ & $\begin{array}{c}\text { モルタル } \\
\text { 中の水量 } \\
(\%)\end{array}$ & 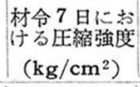 & 強度の比 \\
\hline No. 311 & 111 & 13.8 & 52.5 & 0.69 \\
\hline No. 312 & 115 & 14.0 & 40.4 & 0.53 \\
\hline No. 330 & 109 & 13.3 & 46.9 & 0.62 \\
\hline No. 45 & 115 & 13.8 & 46.4 & 0.61 \\
\hline No.1115* & 96 & 13.2 & 75.8 & 1.00 \\
\hline 借 & $\begin{array}{c}\text { * はコット } \\
\text { 材令 } 7 \text { 日 } \\
\text { 用した。 }\end{array}$ & $\begin{array}{l}\text { レ系フライ } \\
\text { っける王縮 }\end{array}$ & $\begin{array}{l}\text { アッシニです } \\
\text { 度試験の砂 }\end{array}$ & $\begin{array}{l}\text { る。 } \\
\text { 目馬砂老使 }\end{array}$ \\
\hline
\end{tabular}

写真一 5.2 ボール ミル

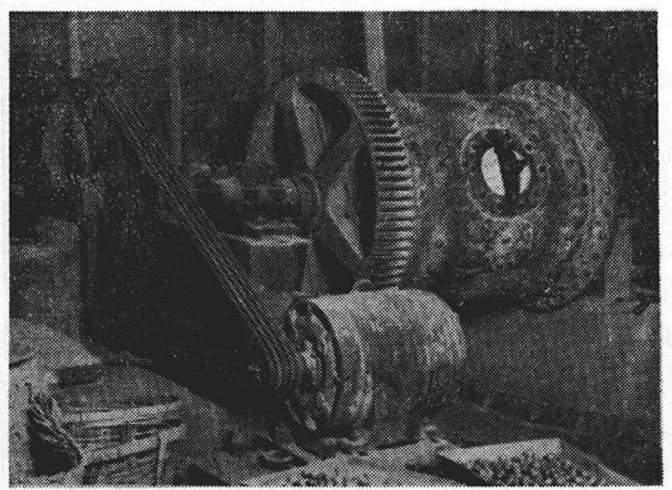

写真一5.3 エアー ミル

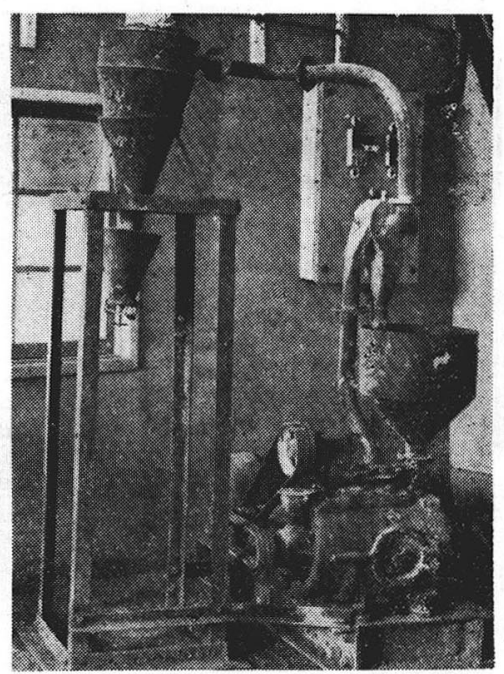

写真一 5.4 ジェット パルベライザ

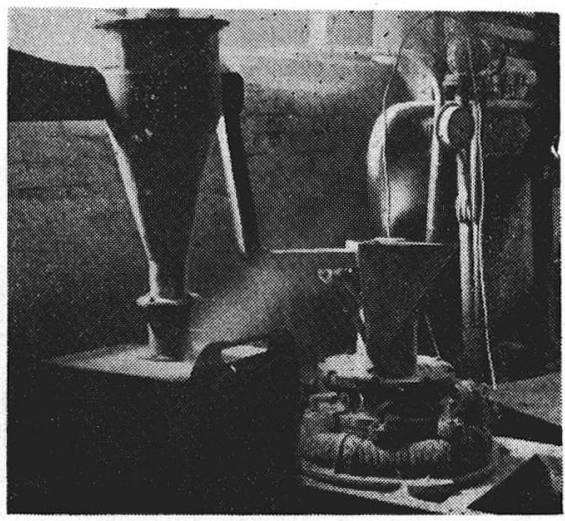


（3）サイクロン系フライアッシュの所要水量比：III〔2]4. の方法飞従つてサイクロン系フライアッシュと コットレル系フライ アッシュの所要水量比を試験した結果は, 表一5.9 亿示すと抒りである。すなわち, サイ クロン系フライアッジはコットレル系フライアッシュにくらべていちじるしく所要水量比が大きく, いずれ も，100\%をはるか比まわつている。

（4）サイクロン系フライ アッシュのポゾラン活性 : 石灰ポゾラン砂モルタル強度試験方法飞從い, 前記 4 種 のサイクロン系フライ アッシュのポゾラン活性を試験した結果は, 表一5.9 亿示すと括りでありて, コットレ ル系フライアッシュにくらべると相当汇少る。

以上, サイクロン系フライアッシュは, 主として所要水量比, 招よびポゾラン活性の上から, そのふホポゾ

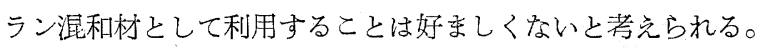

2. 各種ミルによるサイクロン系フライアッシュの粉倮試験

(1) 試験用いたミル：試験用いたミルは，ボールミル・エアーミル*・ジェットパルベライザ** の 3 種で，各ミルの外観は写真一5.2 5.4 亿示すと括りである。な招 3 種のミルのうち, よく知られているボール ミルは別として，エアーミル执よびジェットパルベライザのあらましは次のと捇りである。

エアーミル：一つのケーシング内で相対する一対のプロペラを，互いに反対方向飞 $3000 \sim 4000$ r. p. m. の速度で回転させ，これに被粉砕物を送入する。被粉砕物はプロペラには祊られ，それら相互の衝突，プロペラ 特よびケーシング内壁との衝突によつて粉砕される。図一5.4 はとの説明図である。すなわち, 被粉研物は, 木 ッパよりスクリューフィーダを通して，ケーシングに送入される。空気はファンの作用によつて，ダンパのつ いているロより内部に吸い込まれ，ケーシングに入つて細かくなつた粉末をともなつて撰粉器に入る。ここで微 粒子群と粗精子群とに分けられ，前者はサイクロン集麇器で捕えられ，後者は再びポッパ飞戻される。

ジェットパルベライザ：円筒形の低いケーシングの周囲に設けられた流体室より，ノズルを通して圧縮空

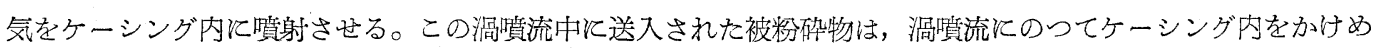
ぐり，粒子相互の衝突怙よびケーシング内壁との衝突によつて粉砕される。図一5.5 はとの説明図である。すな わち, 被粉砕物はポッパより送入管を通じてケーシング内に送入される。ケーシング内で粉砕された粗粒子群は 気流にのつて上景し，蓋体とサイクロンとの間を通つて，サイクロンの内部に渦流しながら導かれる。ここで微 粒子群と粗精子群とに分けられ, 前者は出口を経てサイクロン集塵器で捕えられ, 後者は中心部を経て再びケー シング内杘される。

(2) 試験結果 : 表一5.8 亿示したサイクロン系フライアッシュのうち,フライアッシュNo. 45 を前記 3 種の ミルを用いて粉砕し，各ミルの大体の粉砕能力 ( $\mathrm{kg} /$ 時/馬力)を推定するとともに，粉研したフライアッシュの 比重・粉末度・所要水量比・ポゾラン活性などを試験した結果は, 表一5・10 捻よび図一5・6 亿示すと和りである。

表一5.10 サイクロン系フライ アッシュの粉砕試験結果の一例

\begin{tabular}{|c|c|c|c|c|c|c|c|c|c|}
\hline 粉 & 厒 & 試 & & & 粉砕 し & : フラ イ & $ア ッ V=$ & の性質 & \\
\hline \multirow[b]{2}{*}{ ミルの種類 } & \multirow[b]{2}{*}{ 馬力数 } & \multirow[b]{2}{*}{$\begin{array}{c}\text { 粉砕能力 } \\
(\mathrm{kg} / \text { 㭙/馬力) }\end{array}$} & \multirow[b]{2}{*}{ 摘 要 } & \multirow[b]{2}{*}{ 比 重 } & \multicolumn{3}{|c|}{ 粉 } & \multirow[b]{2}{*}{$\begin{array}{c}\text { 所要水量比 } \\
(\%) \\
\end{array}$} & \multirow{2}{*}{$\begin{array}{l}\text { 石灰モル夕 } \\
\text { ル詩験材令 } \\
7 \text { 日強度 } \\
\left(\mathrm{kg} / \mathrm{cm}^{2}\right)\end{array}$} \\
\hline & & & & & $\begin{array}{l}88 \mu \text { フル } \\
\text { 残分 }(\%)\end{array}$ & $\begin{array}{l}44 \mu \text { フルイ } \\
\text { 残分 }(\%)\end{array}$ & $\begin{array}{l}\text { 此重計万法 } \\
\text { 比表面積 } \\
\left(\mathrm{cm}^{2} / \mathrm{g}\right)\end{array}$ & & \\
\hline \multirow{2}{*}{ ボール } & \multirow{2}{*}{10} & 18 & $\begin{array}{l}1 " \text { ポール } \\
85 \mathrm{~kg} \text { 使用 }\end{array}$ & 2.14 & 2.7 & 24.5 & 1960 & - & - \\
\hline & & 10 & $"$ & 2.22 & 1.5 & 17.9 & 2560 & 107 & 74.5 \\
\hline \multirow{2}{*}{ エアー } & \multirow{2}{*}{5} & $20^{*}$ & & $2.10^{* *}$ & 1.3 & 18.9 & 2130 & 一 & - \\
\hline & & $10^{*}$ & & $2.11^{* *}$ & 1.1 & 17.9 & 2650 & 109 & 73.7 \\
\hline 涪エットラインザ & 17.5 & 5 & $\underset{\left(5 \mathrm{~kg} / \mathrm{cm}^{2}\right)}{\text { 力 }}$ & 2.32 & 1.2 & 11.5 & 3100 & 101 & 78.8 \\
\hline 粉砕前 & îf のフ & ライ アッ & $V=$ & 2.05 & 7.2 & 29.2 & 1810 & 115 & 46.4 \\
\hline \multicolumn{10}{|c|}{$\begin{array}{l}\text { * 春験の都合て，循環再粉砕が完全に行われなからたためこの值は } \\
\text { ** 同上の理由により, 粉砕が完全でないので，多少小さくでている。 } \\
\text { 石灰モルタル陚験の砂は相馬砂を用いた。 }\end{array}$} \\
\hline
\end{tabular}

* 新三菱重工業 $\mathrm{K} \mathrm{K}$ 製品, **笨本鉄工所製品 
図一5.4 エアー ミル

(1)被粉碎物木ッパ

(2)スクリュ一送入装置

(3)ケーンンケ

(4)プロペラ

(5)ダンパ

(6)空気量調節孔

(7)撰粉装置

(8)モータ

(9)ファン

(10ரヘック

(11)空気出口

(192サイクロン集歴器

(13粉末取出口

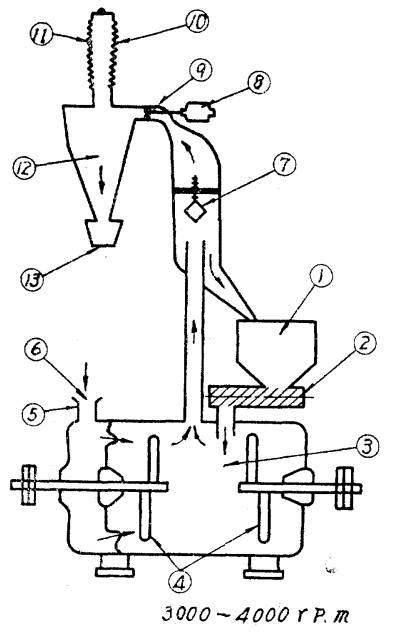

表一5.9 怙よび図一-5.5から次のととが認 められる。

（i） 粉砕後のフライ アッシュの比重は, 総じて粉砕前のむのより増加し, その程度は 粉砕の程度に応じて大きくなつている。この ことは,逆にサイクロン系フライ アッシュを 粉砕する場合には，比重試験飞よつてその粉 砕程度の大体のめやすをつけうることを示す ものである。ただこれらの粉砕したフライ アッシュのうちで,エアーミルで粉砕したフ ライ アッシュは，その比重が約 2.1 であつ て,粉砕処理を経たものであるとかかわらず， 他の粉砕したフライアッシュに比して小さ いのは，試験の都合で完全な循環再粉砕を行 えず，一部に風フイルの効果が入つたためと 思わ机る，

（ii）フルイ残分がほぼ同程度の粉砕した フライアッシュの粒度分布状態は，粉砕に 用いたミルの型式に関せずほぼ同様で，サイ
図一5.5 ジェット パルベライザ

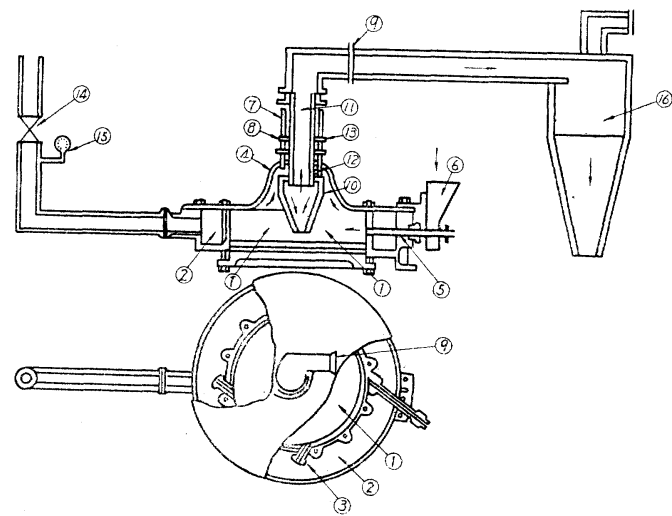

(1)ケーンン
(2)流体室
(3) ス
(4)蓋
(5)体料送入管
(6) 原料ホッパ

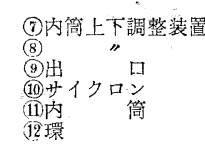

(13内筒上下調整装置

(14) \ツ

(16)サイクロン集璼器

図一5.6 粉砕したフライ アッシュの粒度分布を ヒストグラムで示したー例

フライ アッシュ：サイクロン系 フライ アッシュNo. 45
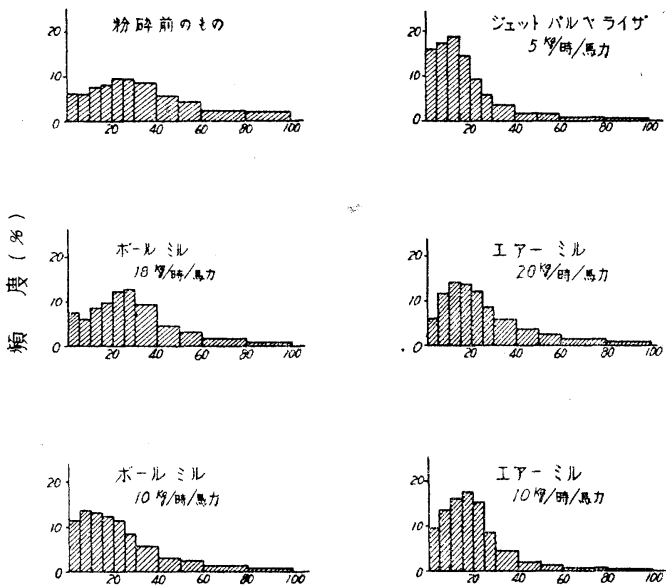

粒子径 $(\mu)$

クロン集㱸器で 捕捉したままの粒度分布をいちじるしく改善し，コットレル系フライアッシュに近い分布にす ることができる。

（iii） 粉砕したフライ アッシュの所要水量比は，粉砕前のものに比べると相当小さくなり，粉砕前のものと コットレル秃フライ アッシュの中間ぐらいになつた。

（iv） 粉砕したフライアッシュを用いた石灰モルタルの材令 7 日強度は, $73.7 \sim 78.8 \mathrm{~kg} / \mathrm{cm}^{2}$ となつていて， サイクロン系フライ アッシュもポンド アッシュと同じく，適当な粉末度になるまで粉伜すれば，ポゾラン混和 材として十分満足すべきむのであることが認められる。おた石灰モルタル強度試験の結果より判定すれば，粉砕 したサイクロン系フライ アッシュは，良質のコットレル系フライ アッシュとほぼ同等のポゾラン活性を有する ことが認められる。

（v）本試験の範囲内でいえば，粉砕方法それ自体は，製品の品質飞特汇影響を和よぼさないものと思われ る。

3. 粉砕したサイクロン系フライアッシュがコンクリートのコンシステンシー执よび圧縮強度に拉よぼす影 
表一5.11 粉砕した飾磨フライ アッシュの比重なよび粉末度

\begin{tabular}{|c|c|c|c|c|c|c|c|}
\hline \multirow[b]{2}{*}{ フライ } & \multirow[b]{2}{*}{ アッンュ } & \multirow[b]{2}{*}{ 比 重 } & \multicolumn{2}{|r|}{ 粉 } & \multirow{2}{*}{$\begin{array}{c}\text { 末 } \\
\text { ブレーン比 } \\
\begin{array}{l}\text { 表面積 } \\
\left(\mathrm{cm}^{2} / \mathrm{g}\right)\end{array}\end{array}$} & 度 & \multirow[b]{2}{*}{$\begin{array}{l}10 \mu \text { 以下の } \\
\text { 百分率 }\end{array}$} \\
\hline & & & $\begin{array}{l}88 \mu \text { フルイ } \\
\text { 残分 }(\%)\end{array}$ & $\begin{array}{l}44 \mu \text { フル } \\
\text { 残分 }(\%)\end{array}$ & & $\begin{array}{l}\text { 比重計方法 } \\
\text { 比表面積 } \\
\left(\mathrm{cm}^{2} / \mathrm{g}\right)\end{array}$ & \\
\hline & $\mathrm{S}$ & 2.08 & 22.9 & 67.0 & 2160 & 640 & 0 \\
\hline $\mathrm{S}^{\prime}$ & (粉 砕) & 2.28 & 2.8 & 16.4 & 5050 & 3500 & 37.1 \\
\hline $\mathrm{S}_{1}$ & & 1.99 & 30.0 & 72.4 & 1330 & 800 & 1.8 \\
\hline $\mathrm{S}_{2}$ & (粉 砕) & 2.10 & 9.2 & 44.2 & 3550 & 1320 & 9.8 \\
\hline $\mathrm{S}_{3}$ & $(\geqslant)$ & 2.23 & 3.0 & 17.4 & 4910 & 3250 & 32.5 \\
\hline
\end{tabular}

(1) フライアッシュ：試験に用いたフライ アッシュは，飾硫フライ アッシュ $\mathrm{S}$ 扰よび $\mathrm{S}_{1}$ を試験用ボール ミルで図一5・7 亿示すような粉 末度に粉砕したもので, その抒もな性質は 表一 5.11 亿示すと挌りである。

(2) 試験

(i) 飾磨フライ アッシュ $\mathrm{S}$ 括よび同粉砕 フライアッシュ $\mathrm{S}^{\prime}$ を用い, 粗骨材の最大寸法 を $25 \mathrm{~mm}$, 単位セメント・フライ アッシュ量 を $306 \mathrm{~kg} / \mathrm{m}^{3}$, フライアッシュオキカエ率を $20 \%$ ，スランプを $6 \mathrm{~cm}$ としたコンクリート，

(ii) 飾磨フライアッシュ $\mathrm{S}_{1}$, 同粉砕フラ イアッシュ $\mathrm{S}_{2}$ 抢よび $\mathrm{S}_{3}$ を用い，粗骨材の最 大寸法を $30 \mathrm{~mm}$, 単位セメント・フライアッ シュ量を $285 \mathrm{~kg} / \mathrm{m}^{3}$ ，フライ アッシュオキカ エ率を $20 \%$ ，スランプを $5 \mathrm{~cm}$ としたコンク リート,

以上を造るための配合执よび同コンクリート
図一5.7 粉砕した フライ アッシュの粒度分 布をヒストグラムで示したー例

フライ アッシュ:サイクロン系フライ アッシュ $\mathrm{S} \cdot \mathrm{S}_{1}$
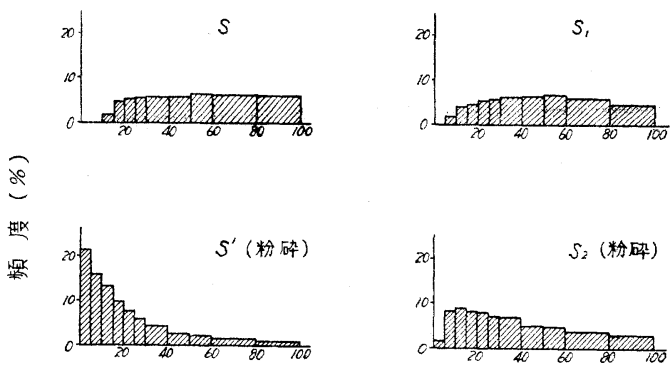

䉼子径 $(\mu)$

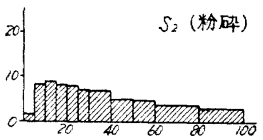

$S_{3}$ (粉暦)

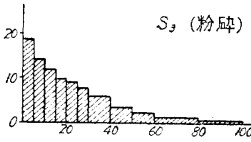

䉼子径 $(\mu)$ を $20^{\circ} \mathrm{C}$ の水中で盖生した場合の圧縮強度は 表一5.12 扰よび 図一5.8 亿示すと招りであつた。

(3) 試験結果

（i）コットレル系フライ アッシュでセメントの $20 \%$ を招きか兄てコンクリートを造つた場合, 所定のコン システンシーをうるために必要な水量は，フライアッシュを用いない場合よりも減少したが，本実験江招いて， 粉砕しない飾磨フライ アッシュを用いた場合，使用水量はフライ アッシュを用いない場合よりも增加してい る。このことは，他のサイクロン系フライ アッシュに招いても見られることである。これに反し，粉砕したフ

表一5.12 粉砕したサイクロン系フライ アッシュがコンクリートのコンシステンシー および圧縮強度におよぼす影響

\begin{tabular}{|c|c|c|c|c|c|c|c|c|c|c|c|c|}
\hline \multirow{2}{*}{$\begin{array}{l}\text { 実験整 } \\
\text { 理番号 }\end{array}$} & \multicolumn{2}{|c|}{ フライ アッシュ } & \multirow{2}{*}{$\begin{array}{c}\text { 粗骨材の } \\
\text { 最大寸法 } \\
(\mathrm{mm})\end{array}$} & \multirow{2}{*}{ 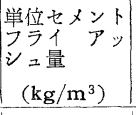 } & \multirow{2}{*}{$\begin{array}{c}\text { ブライ } \\
\text { ア兴さ } \\
\text { オカ侣 } \\
(\%)\end{array}$} & \multirow{2}{*}{$\begin{array}{l}\text { 単位水量 } \\
\left(\mathrm{kg} / \mathrm{m}^{3}\right)\end{array}$} & \multirow{2}{*}{\begin{tabular}{|c} 
粗細亨材 \\
重量比
\end{tabular}} & \multirow{2}{*}{$\begin{array}{r}\text { スランプ } \\
(\mathrm{cm})\end{array}$} & \multicolumn{4}{|c|}{ 压縮強度 $\left(\mathrm{kg} / \mathrm{cm}^{2}\right)$} \\
\hline & 名称 & $\left|\begin{array}{lll}44 \mu & \multicolumn{1}{c}{\mid} \\
\text { 残分 }(\%)\end{array}\right|$ & & & & & & & 28日 & 91日 & 6 月 & 1 年 \\
\hline \multirow{3}{*}{203} & - & - & \multirow{3}{*}{25} & \multirow{3}{*}{306} & 0 & 190 & \multirow{3}{*}{1.1} & \multirow{3}{*}{6} & 244 & 293 & 319 & - \\
\hline & $\mathrm{s}$ & 67.0 & & & 20 & 198 & & & 158 & 225 & 267 & - \\
\hline & $\mathrm{S}^{\prime}$ & 16.4 & & & " & 188 & & & 196 & 294 & 343 & - \\
\hline \multirow{4}{*}{204} & - & & \multirow{4}{*}{30} & \multirow{4}{*}{285} & 0 & 172 & \multirow{4}{*}{1.5} & \multirow{4}{*}{5} & 263 & 310 & 322 & 327 \\
\hline & $\mathrm{S}_{1}$ & 72.4 & & & 20 & 186 & & & 145 & 205 & 246 & 253 \\
\hline & $\mathrm{S}_{2}$ & 44.2 & & & $"$ & 175 & & & 185 & 261 & 309 & 320 \\
\hline & $\mathrm{S}_{3}$ & 17.4 & & & $"$ & 173 & & & 212 & 296 & 328 & 324 \\
\hline
\end{tabular}


ライアッシュを用いたコンクリートの使用 水量は，フライ アッシュを用いない場合と ほぼ同程度であり，サイクロン系フライア ッシュを適当な粉末度に粉伜した場合には， サイクロン系フライ アッシュ以外の混和材 にしばしば見られるようなコンクリートの単 位水量の増加は，認められない。

(ii) 約 $20^{\circ} \mathrm{C}$ の水中養生を行う場合, 粉 砕したフライ アッシュで，セメントの $20 \%$ 。 を括きかえて造つたコンクリートの強度は， 早期材令飞括いては，フライアッシュを用 いないものよりも弱いが，長期材令に和いて はいちじるしい強度增進を示し, フライア ッシュを用いないものと同程度となり，材令 の増加にとむなう強度の增進状態は, 良質の コットレル系フライアッシュとほぼ同程度 であるとみなすことができる。

(iii）粉砕したフライアッシュは，その 粘子形状の点を除けば, 化学成分・粉末度・ ポゾラン活性などは良質のコットレル系フライ アッシュとなえら相違するところがない。従つて粉砕したフラ イアッシュがコンクリートの性質に捛よぼす影響は，コンシステンシーを除けば，良質のコットレル系フライ アッシュに抢ける場合とほぼ同程度とみなしてなんら差支光ないものと思われる。

\section{VI. 結 語}

以上, 各種の試験の結果, 火力発電所の捨灰は, 次飞示すようとポゾラン混和材としてすべて有用であること が明らかになつた。

(a) コットレル系フライアッシュは，㲦燥の状態でこれを採取すれば，そのままこれをポゾラン混和材と

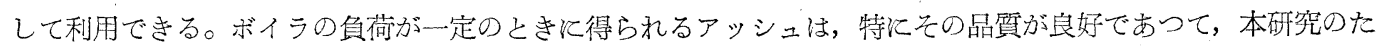
めと使用した悪いフライアッシュは, ボイラ運転休止直前の負荷変動時を利用して兄た特殊の生産物で, これ は廃雍しなけ狄ならないものである。な拉，本試験研究の結果，コットレル系フライアッシュの実用化に当 つて定めた仕様を参考のために示せば，附録フライアッシュ仕様書案のと称りである。

（b）サイクロン系フライアッシュは，乾燥状態でこれを採取する場合，そのままこれをポゾランとして利 用するの法好むくない。しかしこれを粉砕して，所定の粉末度とする場合には，市販の混和材よりポゾラン活 性に富み, コットレル系フライアッシュに撤するものが得られる。粉砕の目的はポゾラン活性の増進にある が，粉砕をうける糈子の数を必要最小限にとどめる差別粉砕方式が好ましい。

（c）ポンドアッシュは，乙れを乾燥して粉砕すればポゾラン 混和材として利用できる。ポンドアッシュ は細かいむのから粗いものまで種々の割合で含まれた状態で得られるから，これの粉砕はポルトランドセメン トクリンカと同時に行い，混合ポルトランド セメントの形にして用いるのが有利と思われる。

※た，コットレル系フライアッシュについて行つた本試験の結果より，大体次のことが結論できるようであ る。

（1）フライアッシュの主成分は，シリカ・アルミナ・酸化鉄などで，シリカは約奖分を占め，ポゾランとし て十分江用いうるものと考觉られる。

(2) フライアッシュは灰白色より黒色を呈するものまで種々あるが，この色は含有炭素量およびポゾラン活 性判定のめやすとはならない。

(3) フライアッシュの比重は，九州炭䄧よび北海道炭を使う場合大体 2.0 2.2 の範团にある。また単位容磧 重量は, 約 $800 \sim 1000 \mathrm{~kg} / \mathrm{m}^{3}$ の範囲汇ある。フライアッシュ粒子の大部分は球状をなしている。

（4）ボイラ運転時棌取するコットレル系フライ アッシュの粉末度は，ブレーン比表面積で 3000 ～ $000 \mathrm{~cm}^{2}$

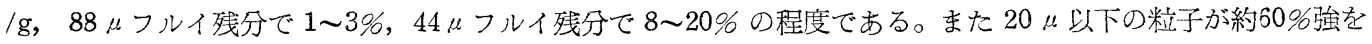


占めて招り，顕微鏡写真によれば $2 \mu$ 以下の糈子むかなり含まれている。

フライ アッシュの品質判定に当つて粉末度を試験する場合, コットレル系フライアッシュに対しては, ブレ ーン方法による比表面積は 1 つ尺度となると考光られる。

（5）フライ アッシュは，その含有孷素のためと吸着性を有するが，その吸着量は必ずしも炭素含有量とは一 定の関係がない。

（6）石灰ポゾラン砂モルタル強度試験方法炕よ机ば，コットレル系フライ アッシュは，十分なポゾラン活性 を有することが認められる。

(7）フライアッシュでポルトランドセメントの一部を牤きがる場合，凝結・始発ともにとのオキカエ率と 従つて延びる。

（8）フライアッシュでポルトランドセメントの一部を执きかえた場合，オートクレーブ膨張試験化よる安定 性は，フライ アッシュを用いないむのとほぼ同程度と考光られる。

（9）良質のフライ アッシュでポルトランド セメントの一部を括きか光た場合，コンクリートの単位水量を減 少することができる。この単位水量減少の程度は，フライアッシュの粉末度，フライアッシュオキカエ率掠 よび砂の粗粒率が大きいほど大きくなる傾向にある。またこの場合，香だ固まらないコンクリートのプラスチシ テーは増加し，ウォーカビリチーはよくなり，実際の施工に当つて見られる材料の分離並びとブリージングは， 軽減されるものと考光られる。

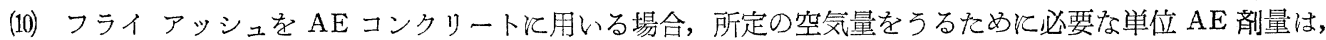
フライ アッシュの吸着量が大きく，才キカエ率が大きいほど，大きくなるととが認められる。

(11) フライ アッシュでポルトランド セメントの一部を括きかえたコンクリートの強度は, フライアッシュ を用いないものよりも，早期材令飞执いては小さいが，材令が増加するにつれて大きくなる。

たとえば，普通ポルトランド セメントを用いて， $21^{\circ} \mathrm{C}$ 水中養生を行つた場合，オキカエ率 $30 \%$ のものは材

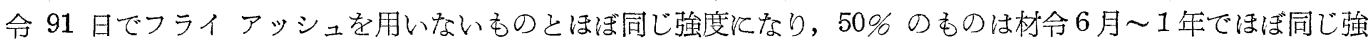
度になつた。このフライ アッシュによる強度の発生は, 養生温度が高いほどはやく，早期に強度のでるセメント ほどはやい。また，強度増進の程度は，コンクリートの配合が筫配合であるほど大きい。

(12) $21^{\circ} \mathrm{C}$ の水中養生を行う場合，良質のフライ アッシュでポルトランド セメントの一部を招きかえて造つ たコンクリートの耐透水性は，早期材令に特いてはフライ アッシュを用いないものよりも招とるが，長期材令 そ赫いてはいちじるしく増進し，フライアッシュを用いないものよりもはるか優れるようになる。フライア

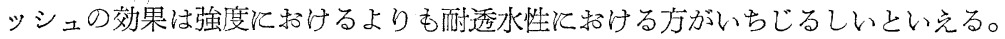

(13) ポルトランド セメントの一部をフライ アッシュで怙きがたコンクリートの凍結融解飞対する抵抗性 は，早期材令ではフライ アッシュを用いないものにくらべて多少䅂とるが，長期材令ではほぼ同程度になる。 またフライ アッシュを用いたモルタル括よびコンクリートの硫酸塩に対する抵抗性は，乙れを用いないものに くらべ，いちじるしく大きい。

(14) フライ アッシュで，ポルトランド セメントの一部を怙きかえたコンクリートの発熱量は，乙れを用いな いものにくらべると,フライ アッシュオキカエ率飞比例して減少する。

(15) フライ アッシュで，ポルトランド セメントの一部を怙きかえたコンクリートの乾燥炕よる収縮は，フラ イアッシュを用いないものにくらべると減少する。

\section{附録 フライ アッシュ仕様書案 （昭和 30 年 3 月）}

\section{1 節 適用の範囲}

この仕様書は 000 新設工事に用いるフライ アッシュに適用する。

\section{2 節 定義}

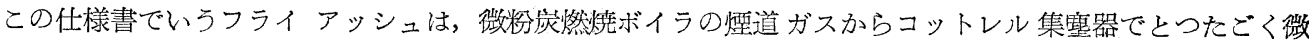
細なものをいう。

\section{3 節 品質}

フライ アッシュは，5節飞規定する方法に 従つて試験した場合，化学分析招よび物理的性質に関する次の 諸条件を満足するむのでなければならない。

化学成分 


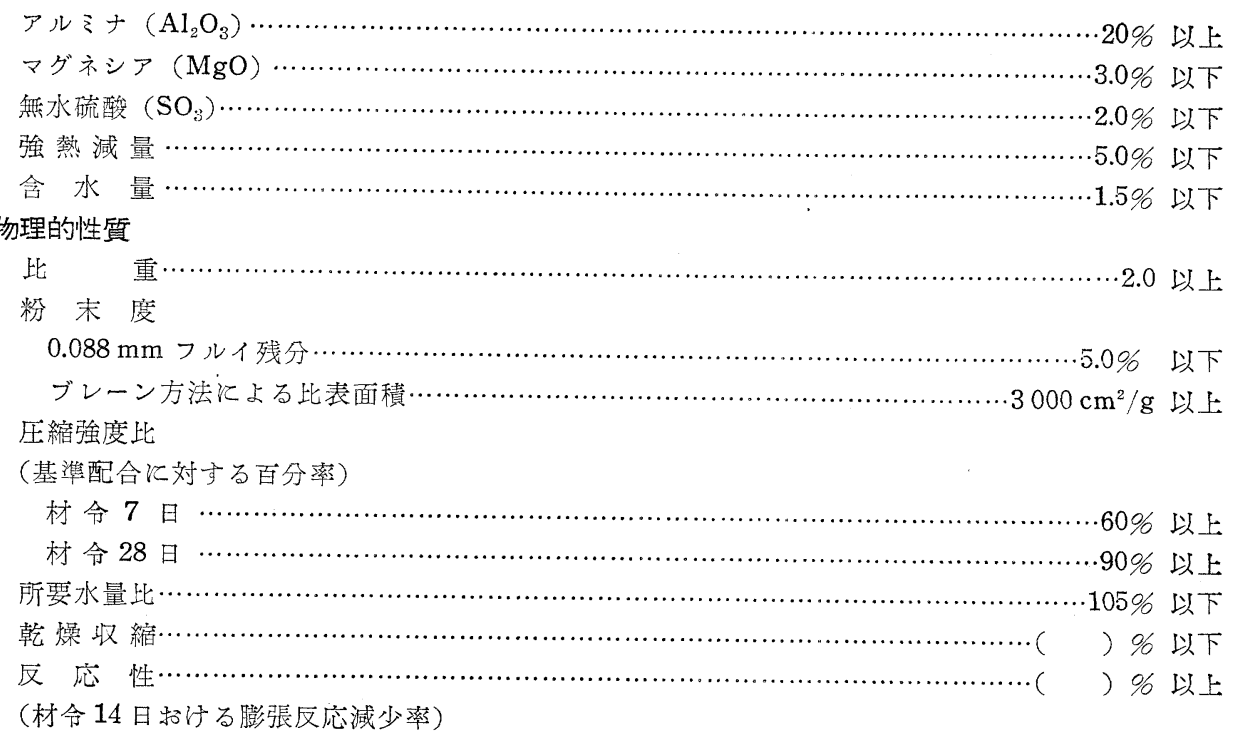

\section{4 条 品質の均一性}

フライ アッシュの粉末度・所要水量比和よび圧縮強度比は，3節に合格し，その均一性は次に示すむので なければならない。ただし，試料採取和よび試験方法は，5節招よび 6 節と従うものとする。

(1) 粉 末 度

$0.088 \mathrm{~mm}$ フルイ残分（\%) 拉よびブレーン方法による比表面積 $\left(\mathrm{cm}^{2} / \mathrm{g}\right)$ は，その平均值和よびネハバの 変動が $\overline{\mathrm{X}} \cdot \mathrm{R}$ 管理図の $3 \sigma$ 管理限界をこえてはならない。

(2) 所要水量比

所要水量比 $(\%)$ の平均值抢よびネハバの変動は $\overline{\mathrm{X}} ・ \mathrm{R}$ 管理図の $3 \sigma$ 管理限界をこえてはならない。

(3) 圧縮強度比

圧縮強度比 $(\%)$ の平均値括よびネハバの変動は $\mathrm{X} ・ \mathrm{R}$ 管理図の $3 \sigma$ 管理限界をこえてはならない。

\section{5 節 試験方法}

フライアッシュの試験は，次に示す方法で行わなければならない。

(1) 化学分析

化学分析は, アルカリ溶ゆう方法によりフライ アッシュを溶ゆうした後, JIS R 5202 (セメントの化学 分析方法）飞準じて行うものとする。ただし，溶ゆうする必要のないものはこの限りでない。

(2) 比重

比重試験は，JIS R 5201 (セメントの物理試験方法) 飞準じて行うものとする。ただし試料は $70 \mathrm{~g}$ と し, フライアッシュを比重ビンに入れ終つてから, 液面の目盛を読むまでの時間は, 気泡を完全洎出す ため 24 時間以上とする。

(3) 粉末 度

$0.088 \mathrm{~mm}$ フルイの残分拉よびブレーン方法による比表面積の測定は, ともに JIS R 5201 (セメントの 物理試験方法）飞準じて行うものとする。ただし，ブレーン方法による場合のフライアッシュのポロシチ 一は, 標準試料のポロシチーにできるだけ近く, 乙かも供試圧縮体作製飞最も適したポロシチーを実験的に 求め，○○の承認を得たものでなければならない。

(4) 圧綰強度比

压縮強度比の試験は，○00用セメントをたは○○の承認したセメントを用い，基準配合扔よび試験配合 の両者について圧縮強度試験を行うものとする。これらの試験用いる供試体の製造および圧縮強度試験 は，次の事項を除きすべて JIS R 5201 (セメントの物理試験方法）によるものとする。

i) 配 合 試験に用いる配合は次のとおりとする。 


項 $\quad$ 目
セメント $(\mathrm{g})$
フライアッシュ（g）
豊浦標準砂（g）
水 $(\mathrm{g})$

\begin{tabular}{|c|c|}
\hline $\begin{array}{c}\text { 基 準 配 合 } \\
520\end{array}$ & $\begin{array}{c}\text { 溒 験 配 合 } \\
364\end{array}$ \\
\hline 0 & 156 \\
\hline 1040 & 1040 \\
\hline 〜215のフローを得るのに必要な量 & \\
\hline
\end{tabular}

ii ）供試体の養生

供陚体は，成形後 24 時間 $20 \pm 3^{\circ} \mathrm{C}$ 飞保つた湿気箱に入れて保存したのち脱ワクし，ただちに完全に 気密な容器に入れ， $40^{\circ} \mathrm{C}$ で試験時まで養生するものとする。ただし強度試験は供試体を $20 \pm 3^{\circ} \mathrm{C}$ 亿冷 やして行うものとする。

iii) 試 験 材 令

圧縮強度試験は，材令 7 日括よび 28 日で行うものとする。

iv）圧縮強度比

圧縮強度の試験值は，供試体 6 個の平均値をとるものとし，圧縮強度比は次式で計算する。

$$
\text { 压縮強度比 }(\%)=\frac{\text { 試験配合の圧縮強度 }}{\text { 基準配合の圧縮強度 }} \times 100
$$

(5) 所要水量比

所要水量比は次式々よつて計算する。

$$
\text { 所要水量比 }(\%)=\frac{(4) \text { 飞招ける試験配合の水量 }}{(4) \text { 亿括ける基準配合の水量 }} \times 100
$$

（6）乾繰収縮（検討中）

乾繰收縮試験用試体の配合は（4）で述べた試験配合と同一とし，供試体の製造招よび試験は ASTM

C 157-52 T そ準じ○○の承認した方法で行うものとする。

（7）反応性（検討中）

材令 14 日飞怙ける膨張反応減少率の試験は，ASTM : C 311-53 T 飞準じ，○○の承認した方法で行う ものとする。

\section{6 節 試料・試験および報告}

フライ アッシュは，出荷飞さきだち，400 t またはとの端数ごとに平均品質を表わすように1口 $5 \mathrm{~kg}$ 以上 の試料を採取し，ただちに品質試験を行い，その結果を報告しなければならない。ただし，材令 28 日の圧縮 強度・乾燥収縮拉よび反応性については試験終了後ただちと報告しなければならない。

4 節の品質の均一性を調べるための試験は, 出荷フライ アッシュ $100 \mathrm{t}$ ごとに平均品質を表わすように 1 口 $5 \mathrm{~kg}$ 以上の試料を採取して行うものとする。ただし, 総計 $10000 \mathrm{t}$ 以上試験したのち品質が均一であるこ とが確認された場合は，試験の回数を変更することができる。

また納入者は○○が要求する場合はただちに試料を送附しなければならない。

な招，報告書の様式・提出先拉よび部数は別途指示するものとする。

\section{7 節 出荷の承認および納入方法}

納入者は，出荷の都度○○の承認を得なければならない。また，承認を得たフライアッシュの受渡し場所 は○○とし，その単位は重量（t) とする。

\section{8 節 包装おび標示}

フライ アッシュを包装する場合は, 紙袋 (JIS Z 1505 大型紙袋準ずる) 入りとし，その正味重量は $40 \mathrm{~kg}$ とする。また，袋の外面にはフライアッシュであることを明らか沉し，他の標示は○○の承認を得たもので なければならない。 


\section{参考文献}

1) R.E. Davis, J.W. Kelly, G.E. Troxell, and H. E. Davis : "Properties of Mortars and Concretes Containing Portland-Pozzolan Cements" Jour. A.C.I. Sep. O Oct. 1935. Proc. Vol. 32.

2) R.E. Davis, R.W. Carlson, J.W. Kelly, and H.E. Davis : "Propesties of Cements and Concretes Containing Fly Ash" Jour. A.C.I. 1937, Proc. Vol. 33.

3) R.E. Davis, H.E. Davis, and J.W. Kelly :"Weathering Resistance of Concretes Containing Fly-Ash Cements" Jour. A.C.I. Jan. 1941. Proc. Vol. 37.

4) A.F. Blanks : "The Use of Portland-Pozzolan Cement by the Bureau of Reclamation" lour. A.C.I. Oct. 1949 .

5) "Symposium on Use of Pozzolanic Materials in Mortars and Concretes." ASTM Special Technical Publication No. 99. October 1949.

6) R.F. Blanks : "Fly Ash as a Pozzolan" Jour. A.C.I. May 1950.

7) "Portland Cement and Pozzolan for Palisades Dam and Power Plant. Palisades Project, Idaho" U.S. Bureau of Reclamation.

8) W. T. McClevahan : "Experience with Fly-Ash Blends in a Test Pavement built in 1938" Engineering News Record. March 12, 1953.

9) G.W. Washa, and N.H. Withey: "Strength and Durability of Concrete Containing Chicago Fly Ash" Jour. A.C.I. Apr. 1953.

10) "Laboratory and Field Investigations of Concrcte, Hungry Horse Dam" Hungry Horse Project Concrete Laboratory Report No. C-699. 1953.

11) L. John Minnick: "Investigations relating to the Use of Fly Ash as a Pozzolanic Material and as an Admixture in Portland Cement Concrete". ASTM 1954.

12）浅岡勝彦，大岡輝雄：“断熱々量計飞よるセメント水和熱試験方法とその実例”日本セメント株式会社，ア サノマスコンセメントに関する文献資料 M-(17) 昭和 18 年 12 月.

13）吉越盛次：“コンクリートの透水坓験方法飞関する一提案” 電力技術研究所報 土木, 第 2 巻, 第 4 号, 昭 和 25 年 1 月.

14）セメント風らるい試験方法, 日本セメント技術協会・

15）水渡英二，荒川正文：“沈降式自動粒度測定器によるセメント粒度分布測定”セメント技術年報, 昭和28年.

16) S.B. Biddle Jr, and Alexander Klein : "A Hydrometer Method for Determining the Fineness of Portland-Pozzolan Cements" Proc. ASTM 1936.

17) “Admixtures for Concrete" Jour. A.C.I. Nov. 1944.

18) C.H. Scholer, and G.M. Smith : "Use of Chicago Fly Ash in Reducing Cement Aggregate Reaction" Jour. A.C.I. Feb. 1952 .

19) Standard Method of Test for Fineness of Portland Cement by the Turbidimeter. ASTM : C $115-42$.

20) Standard Method of Test for Autoclave Expansion of Portland Cement. ASTM : C 151 ?.

21) Tentative Methoh of testing for Fly Ash as an Admixture for Portlond Cement Con. e. ASTM : C 311-53 T.

22) Tentative Specification for Fly Ash for Use as an Admixture in Portland Cement Conc ASTM : C 350-54 T.

23) Tentative Method of Sampling and Testing Fly Ash for Use as an Admixture in Portland Cemcnt Concrete. ASTM : C 311-54 T.

24) Tentative Method of test for Bleeding of Concrete. ASTM : C 232-49 T.

25) Tentave Method of test for Resistance of Concrete Specimens to Rapid Freezing and Thawing in Water. ASTM : C 290-52 T.

26) Tentative Method of test for Volume Change of Cement Mortar and Concrete. ASTM : C 157-52 T.

27）セメント技術年報 昭和 28 年. 